\title{
Lest We Commemorate: \\ Assembling Canada's Great War Centenary, 2014-2018
}

\author{
by \\ Breanna Lester, BA (Hons), MA
}

A thesis submitted to the Faculty of Graduate and Postdoctoral Affairs in partial fulfillment of the requirements for the degree of Doctor of Philosophy

in

History

Carleton University

Ottawa, Ontario

(C) 2021, Breanna Lester 


\begin{abstract}
This dissertation studies the commemorative practices of the centenary of the First World War (2014-2018). The centenary occurred within a decade-long commemorative period known as the "Road to 2017" (2010-2017) that was itself dedicated to marking the $150^{\text {th }}$ anniversary of Confederation. While participating in commemorations, particularly federally sanctioned ones, is socially and culturally constructed as an act of good citizenship, these elements have resulted in scholarship that focusses on nation, nationalism, and collective memory. In contrast, this dissertation approaches commemoration through the lens of labour and its practitioners as history workers.
\end{abstract}

To do so, the dissertation applies assemblage theory and a wide range of methods to an archive of Access to Information and Privacy (ATIP) records, interviews with commemoration professionals inside and outside of government, media, and ethnographic observations. It explores how battlefields were assembled into commemorative landscapes and recognizes both the human and non-human agency involved in those processes. The dissertation then focusses acutely on the day-to-day bureaucratic work involved with designing, enacting, and managing centenary events and practices, and considers the affective nature of that labour on the people who did it. Throughout the chapters, interviews and ATIP records provide unique perspective from inside the various bureaucratic and commemorative assemblages that intersected during the First World War centenary, while ethnographic fieldwork reveals some of the hidden and unexpected elements of commemorative experiences.

This dissertation argues that more scholarly attention should be paid to the practical and logistical components of commemoration. To do so means to better 
understand what makes commemorations affective, including why accessible and operating toilets can be as important as navigating the political nuances of which flags to display in what order at a centenary ceremony. An attention to practice, furthermore, also makes possible a more generous, empathetic appreciation of a group of ofteninvisible history workers who, despite often stressful working conditions, sacrificed aspects of their personal lives and wellbeing to execute the important large-scale events that comprised the Canadian centenary experience. 


\section{Acknowledgements}

Earning a History PhD has been a goal of mine since I was young. Though I did not know anyone with a $\mathrm{PhD}$, and none of my relatives had one, I loved history and wanted to pursue it academically as far as I could go. Prior to and throughout my undergrad, I was told numerous times that a history degree would not lead me into a career, that it was a "useless degree" unless I wanted to teach (which I did not). However, my mom taught me when I was young that I could do anything I put my mind to. This is what I put my mind to, and I am proud to have accomplished it.

When I made the decision to leave home at seventeen years old and start my undergraduate degree at Carleton University, I never imagined it would become my home for nine wonderful years. I would first like to thank the Department of History for nurturing my love of history and supporting my academic pursuits throughout my B.A. and $\mathrm{PhD}$. To James (Jim) Opp for igniting my love of historical theory. To Yvonne Aleksandra (Alek) Bennett for the lengthy comments on my papers, for the many conversations over tea, and for encouraging me to pursue a master's degree. To the administrative staff in the Department of History, especially Joan White for the invaluable support over the years. Joan, you are an institution, and I am so grateful to have benefited from your guidance. Thank you to my committee members David Dean and Paul Litt, to my Internal Examiner Tonya Davidson, and to my External Examiner Amy Tyson. I and this project are better thanks to your comments and discussion. Thank you most of all to my supervisor John C. Walsh for everything you did to get me to the finish line. Your guidance, support, and light-hearted toilet jokes kept me going during the stressful, demoralizing moments doctoral work inevitably facilitates. Thank you for 
frequently reminding me how important my work is, for showing your enthusiasm, even when I did not, and for putting up with my stubborn determination, though you knew working forty-hour weeks, TA-ing, and trying to write a dissertation was not an optimal recipe for success.

I was lucky to have received generous financial support over the last five years which greatly assisted my ability to research and complete this dissertation. Thank you to the Department of History, the contributors to the Helen and Joe Connolly Bursary, the M. Gaulin Bursary, the S.F. Wise Graduate Bursary, the Underhill Travel Bursary, and the Shannon Bursary for your financial support. Thank you to my wonderful managers at Canadian Development Consultants International, Sean Stoyles, Laurie Howe, and Chris Petrusic for affording me the flexibility to pursue the $\mathrm{PhD}$ while working a job I love.

To the incredible staff in the ATIP department at VAC, especially Cathy O'Leary-McDonald: thank you and your team for your prompt retrieval of the $8000+$ record that comprised the majority of my ATIP archive, and for connecting me with four of my fifteen participants. And of course, to my interviewees: Tim Cook; Jean-Pierre Morin; Douglas Ballam; Steve Harris; Caitlin Bailey; John Cannon; Phil Craig; Jérémie LeBlanc; David Patterson; R.H. Thomson; Christina Gaudet; Robert Löken; Sylvie Thibodeau-Sealy; Peter Mills; and Ocel Dauphinais-Matheson. Thank you for sharing your stories with me. I hope I was able to accurately capture the essence of your labour. I am especially grateful to Sylvie Thibodeau-Sealy and Jean-Pierre Morin for reading samples of my work and validating my findings.

I have made many incredible life-long friendships over my nine years as a postsecondary student. To Christine Mason, Thomas Sloss, Bill Bell, Sam Wainwright, Allie 
McGee, and Mica Jorgenson: thank you for your encouragement all these years. And to Rick Duthie, Sandy Barron, Helen Kennedy, and Tyla Betke: I could not have done this without your constant and unwavering support. Thank you for indulging in many a pint at Mike's Place, for commiserating with me, but never validating my Imposter Syndrome, and for our backyard hangs. This one is for you.

I also owe incredible gratitude to those closest to me. To Julie Potter and David Gill: thank you for engaging in many dinner conversations about my work and sharing your experiences as public servants. To my grandparents Ken (Pompa) and Janet (Grammie) Spierenburg: I am proud to be your Dr. Yardy. Thank you to my Aunt Vicki who fostered my love of reading and, together with my Uncle Allen, have been my cheerleaders since birth. To my partner Patrick Gill: thank you for traipsing around Europe with me, for never getting tired of war museums, never complaining of sore feet after walking battlefields all day, for your advice, and support over the last four years. To my dad, Allan Lester: thank you for always checking in on me and, though this stuff is out of your wheelhouse, I appreciate your pride and support in everything I do. I am proud to be the first Dr. Lester in the family. To my sister, Desirae: you have taught me so much in your twelve years of life, despite me being the much older sister. Thank you for being your goofy, confident, and intelligent self. You helped me through this more than you will ever know. And finally to my mom, Theresa Hunt: thank you for making me sit at the kitchen table after school every day and do my homework, for scolding me when I called myself "stupid" because I could not solve a word problem, and for showing me true strength, perseverance, and ambition. Everything you taught me led me here, and for that, I will always be grateful. 


\section{Table of Contents}

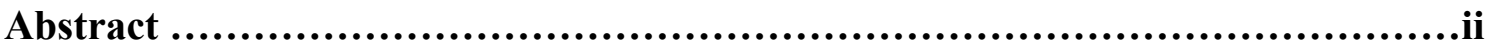

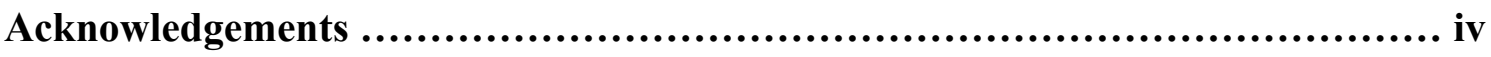

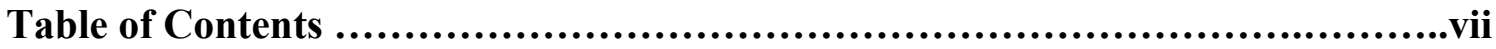

List of Tables and Figures.............................................................viii

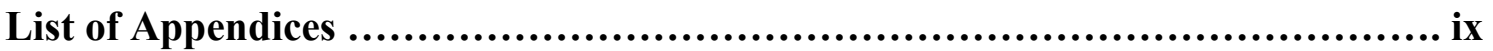

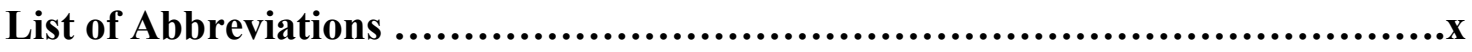

Chapter One: Introduction.........................................................1

Chapter Two: Assembling Commemorative Landscapes...........................36

Chapter Three: Assembling Commemorative Work...............................96

Chapter Four: The Narratives of Commemorative Assemblages...................138

Chapter Five: Emotions, Work, and Commemorative Assemblages.................186

Chapter Six:Conclusion............................................................216

Appendix A - Interviewee Biographies..........................................227

Appendix B - Certification of Institutional Ethics Clearance......................240

Appendix C - Consent Form ................................................. 242

Appendix D - Interview Guide ................................................. 244

Appendix E - Qualtrics Survey Questions .................................. 246

Appendix F - ATIP Tracking Chart............................................. 248

Appendix G - ATIP How-To Guide............................................. 249

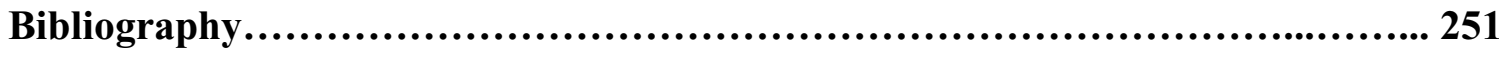




\section{List of Tables and Figures}

\section{Tables}

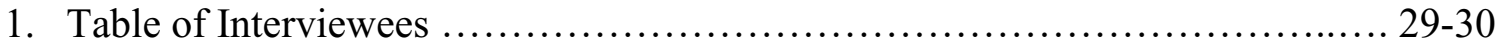

\section{Figures}

1.1. Neglected felt poppy amidst litter in downtown Ottawa $\ldots \ldots \ldots \ldots \ldots \ldots \ldots \ldots \ldots . \ldots$

2.1. "Brooding Soldier" Monument, St. Julien, Belgium .......................... 49

2.2. Canadian Passchendaele Memorial, Crest Farm, Belgium ....................... 50

2.3. Chateau, Memorial Museum Passchendaele 1917, Zonnebeke, Belgium .......... 52

2.4. Map showing locations of major Canadian First World War battles ............... 62

2.5. Aerial image of the Beaumont-Hamel Newfoundland Memorial landscape ....... 62

2.6. Danger Tree replica ...................................................... 65

2.7. Bronze plaques at Beaumont-Hamel Newfoundland Memorial ..................... 66

2.8. Caribou statue at Beaumont-Hamel Newfoundland Memorial .................... 66

2.9. Uxbridge Road Trench, Beaumont-Hamel Newfoundland Memorial ............... 68

2.10. National Vimy Memorial self-guided tour map .............................. 70

2.11. Vimy Centennial Park mirror reflecting adjacent monument ................... 73

2.12. Situational map of the Beaumont-Hamel Newfoundland Memorial ............... 78

2.13. Situational map of the National Vimy Memorial ............................ 78

2.14. Situational map of the Passchendaele assemblage ............................ 79

2.15. Situational map of the battlefield tour group routes ........................... 79

2.16. Map showing Trail of the Caribou locations .............................. 82

2.17. Map showing major Canadian memorials on the Ypres Salient ................ 85

2.18. "Canadian Road to Passchendaele" trail map .............................. 85

3.1. Situational map of the centennial bureaucratic assemblage ..................... 137

4.1. Vimy 100 promotional poster ........................................ 149

4.2. Passchendaele 100 Veteran's Week promotional poster ....................... 149

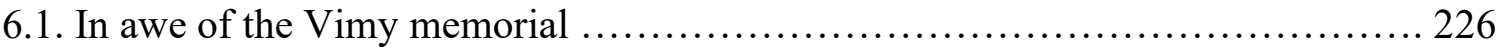




\section{List of Appendices}

Appendix A - Interviewee Biographies........................................... 227

Appendix B - Certification of Institutional Ethics Clearance.................... 240

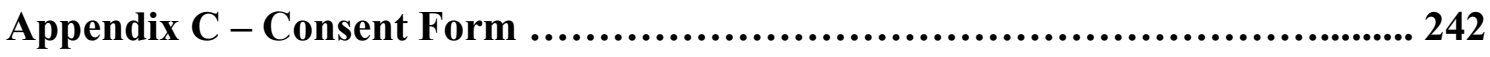

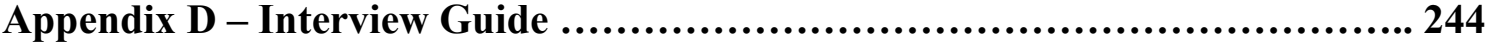

Appendix E - Qualtrics Survey Questions ....................................... 246

Appendix F - ATIP Tracking Chart................................................ 248

Appendix G - ATIP How-To Guide............................................... 249 


\title{
List of Abbreviations
}

\author{
ADM - Assistant Deputy Minister \\ ANT - Actor-Network Theory \\ ANZAC - Australian and New Zealand Army Corps \\ ATIP - Access to Information and Privacy \\ AWM - Australian War Memorial \\ CAF - Canadian Armed Forces \\ CBMC - Canadian Battlefields Memorial Committee \\ CBMRP - Canadian Battlefields Memorial Restoration Project \\ CEF - Canadian Expeditionary Force \\ CIRNAC - Crown-Indigenous Relations and Northern Affairs Canada \\ CPP - Commemorative Partnership Programme \\ DG - Director General \\ DHH - Directorate of History and Heritage \\ DND - Department of National Defence \\ FWW - First World War \\ GEDS - Government Electronic Directory Services \\ GoC - Government of Canada \\ GoNL - Government of Newfoundland and Labrador \\ ICC - Interdepartmental Commemorations Committee \\ INAC - Indigenous and Northern Affairs Canada \\ PCH - Canadian Heritage \\ PSPC - Public Services and Procurement Canada \\ PWGSC - Public Works and Government Services Canada \\ RCL - Royal Canadian Legion \\ RNR - Royal Newfoundland Regiment \\ SWW - Second World War \\ TRC - Truth and Reconciliation Commission \\ VAC - Veterans Affairs Canada
}




\section{Chapter One: Introduction}

Between 2014 and 2018, Veterans Affairs Canada (VAC), in conjunction with its partnering departments and non-governmental partners, executed ten domestic and overseas events to mark the hundredth anniversary of the First World War. ${ }^{1}$ The concurrent bicentennial of the War of 1812 (2012-2015), Confederation (Canada 150) (2017), fifth anniversary of the end of Canada's mission in Afghanistan (2019), and seventy-fifth anniversary of the Second World War (2014-2020), cumulatively made nearly a decade of interconnected commemorations that involved VAC in various ways. Though the initial budget for the First World War centenary was $\$ 1$ million for overseas activities and $\$ 0.4$ million for domestic events, VAC and its constituents spent a total of $\$ 13$ million. ${ }^{2}$ Early in the planning phase, the domestic events that were to occur included the declaration of war (2014), the $2^{\text {nd }}$ Battle of Ypres (2015), Battle of the Somme and Beaumont-Hamel (2016), Battle of Vimy Ridge (2017), Canada's Last Hundred Days (2018), and Armistice (2018). ${ }^{3}$ According to VAC's website, four additional large-scale ceremonies were also held overseas including at Beaumont-Hamel (2016), Vimy (2017),

\footnotetext{
${ }^{1}$ This account of the commemorative events that occurred between 2014 and 2018 is by no means exhaustive. The goal of this dissertation is to show the commemorative processes as is told through my interactions with commemoration professionals and my archive of Access to Information and Privacy (ATIP) records. Lee Berthiaume, "Historians unimpressed with Canada's First World War centenary commemorations," The Canadian Press (2018), https://www.ctvnews.ca/politics/historians-unimpressedwith-canada-s-first-world-war-centenary-commemorations-1.4174008.

${ }^{2}$ This figure is low in comparison to other former allied nations. The British government reportedly budgeted 100 million GBP, Australia: \$80 million AUD, and New Zealand \$20 million NZD. This is largely because of an overspending by Stephen Harper's conservative government on the $200^{\text {th }}$ anniversary of the War of 1812 which costed \$28 million and did not garner as much support as anticipated: Berthiaume, "Historians unimpressed with Canada's First World War centenary commemorations," https://www.ctvnews.ca/politics/historians-unimpressed-with-canada-s-first-world-war-centenarycommemorations-1.4174008; https://encyclopedia.1914-1918-online.net/article/centenary_canada ${ }^{3} \mathrm{Ibid}$. Though it is sometimes spelled without a hyphen, for consistency, I will include the hyphen in "Beaumont-Hamel" following how it is written in all Government of Canada correspondence.
} 
Passchendaele (2017), and Armistice (2018). ${ }^{4}$ Beyond the ceremonies, there were also several complementary projects either spearheaded or funded by the Government of Canada that assisted in the centenary commemorations.

On August 4, 2014, Prime Minister Stephen Harper participated in a ceremony to mark the hundredth anniversary of the beginning of the First World War at the National War Memorial in Ottawa. ${ }^{5}$ This event included Parks Canada interpreters dressed in full First World War uniforms, and a flight demonstration of British S.E.5 replica biplanes. Simultaneously, Halifax shut off lights on all its major landmarks, a special ecumenical service was held at the Basilica Cathedral of St. John the Baptist in St. John's, and "newsboys" handed out information pamphlets on the First World War in Toronto. ${ }^{6}$ Later that fall, on Remembrance Day, the National War Memorial was re-dedicated and names and dates of the South African War (1899-1904) and the mission in Afghanistan (20012014), as well as the addition of the inscription: "In Service to Canada // Au service du Canada" on the front and rear of the monument were unveiled. ${ }^{7}$

In April 2015, the Calgary Highlanders, Royal Hamilton Light Infantry and the Canadian Scottish Regiments represented the original Battalions of the $1^{\text {st }}$ Canadian Division travelled to Europe on pilgrimage to mark the hundredth anniversary of the Battle of Second Ypres and were subsequently saluted by Queen Elizabeth II on a

\footnotetext{
4 "World Wars Commemoration \#CanadaRemembers," Veterans Affairs Canada, April 16, 2019, https://www.veterans.gc.ca/eng/remembrance/world-war-commemorations.

5 “Public Events for August 4, 2014," Veterans Affairs Canada, August 3, 2014, https://www.canada.ca/en/news/archive/2014/08/public-events-august-4-2014.html.

${ }^{6}$ Emily Chan, "Canadians stop to remember $100^{\text {th }}$ anniversary of First World War," CTVNews.ca, August 4, 2014, https:/www.ctvnews.ca/canada/canadians-stop-to-remember-100th-anniversary-of-first-worldwar-1.1945332.

7 “National War Memorial," Veterans Affairs Canada, October 29, 2020, https://www.veterans.gc.ca/eng/remembrance/memorials/national-inventory-canadianmemorials/details/9429.
} 
stopover in London. ${ }^{8}$ On May 3, a statue of Lieutenant-Colonel John McCrae was unveiled in Ottawa to mark the hundredth anniversary of the penning of his famous poem, In Flanders Fields. A duplicate statue was later unveiled in his hometown of Guelph, Ontario in June. ${ }^{9}$ Also completed in 2015 was the final report of the Truth and Reconciliation Commission of Canada which was to draw more attention to the 4000 (fifty decorated) Indigenous Canadian Expeditionary Force (CEF) participants. ${ }^{10}$ And, of course, in October, Justin Trudeau and his Liberal Party won the federal election. As is discussed in subsequent chapters, this would impact the planned events of the centenary.

2016 focussed on the Battle of Beaumont-Hamel. On July 1, 2016, 5000 visitors gathered at the Beaumont-Hamel memorial for the battle's centennial, including 1500 Canadians. ${ }^{11}$ Highlights of the 4 p.m. ceremony included a reading of the Commitment to Remember by Inuit teenagers Ethan Shiwak and Taylor Ivany in Inuktitut, a performance of the Ennis Sisters' song "Sing You Home," in addition to speeches by Prince Charles and other dignitaries including the Minister of Veterans Affairs. ${ }^{12}$ Others in attendance included Speaker of the Senate, Ambassador of Canada to France, French Secretary of

\footnotetext{
${ }^{8}$ Michelle Zilio, "Queen salutes Canadian regiments in First World War commemoration," CTVNews.ca, April 19, 2015, https://www.ctvnews.ca/canada/queen-salutes-canadian-regiments-in-first-world-warcommemoration-1.2334645.

9 "John McCrae statues to be unveiled a century after In Flanders Fields," The Canadian Press, April 19, 2015, https://www.cbc.ca/news/canada/john-mccrae-statues-to-be-unveiled-a-century-after-in-flandersfields-1.3039564 ${ }^{10}$ ATIP, Cindy Clegg, "Vimy 100 Vision,” April 2016.

${ }^{11}$ ATIP, Veterans Affairs Canada, "First World War Centennial Planning Committee," February 21, 2012; ATIP, Veterans Affairs Canada, "100th Anniversary of the Battles of the Somme and Beaumont-Hamel Lessons Learned," August 5, 2017.

${ }^{12}$ Geoff Bartlett, "Prince Charles honours regiment at Beaumont-Hamel ceremony in France," CBC News, July 1, 2016, https://www.cbc.ca/news/canada/newfoundland-labrador/beaumont-hamel-prince-charles1.3661410; Peter Mills, interview by Breanna Lester, November 20, 2019.
} 
State for Veterans, representatives of Canadian veterans' associations, veterans, and Canadian youth. ${ }^{13}$

2017 was a big commemorative year for Canada and, as government records indicate, the peak of the war's centennial events. ${ }^{14}$ This included Vimy 100 in April and Passchendaele 100 in November, as well as Canada's national sesquicentennial in July. Final numbers indicate there were 50000 people in attendance at the Vimy memorial in France, including 10000 Canadian students and 350 French volunteers. ${ }^{15}$ The event itself took twenty months to plan (commenced in earnest in 2015) and over one million people watched from home on $\mathrm{CBC}$ and $\mathrm{CTV} .{ }^{16}$ Highlights of the event included a pre-show featuring musical performances by Johnny Reid and francophone singer-songwriter Coeur de pirate, and performances by Canadian filmmaker Paul Gross and Indigenous performers including well-known Inuk singer, Elisapie. The pre-show commenced at noon on April 9, 2017, and the ceremony started at 4 p.m. There were also several events surrounding the Vimy ceremony including a twenty-minute sound-and-light show in the neighbouring town of Arras called "Three Seconds of Light" that ran nightly from April 5 to 12. According to Kent Hehr, Minister of Veterans Affairs and Associate Minister of

\footnotetext{
13 "Government of Canada marks $100^{\text {th }}$ anniversary of the Battle of Beaumont-Hamel," Veterans Affairs Canada, July 1, 2016, https://www.newswire.ca/news-releases/government-of-canada-marks-100thanniversary-of-the-battle-of-beaumont-hamel-585189171.html.

${ }^{14}$ ATIP, Veterans Affairs Canada, "First World War Centennial Interdepartmental Committee," September 14, 2012.

${ }^{15}$ ATIP, Canadian High Commission, "Veterans Affairs Canada - Commemoration Division Commemoration of 100th Anniversary of the Battle of Vimy Ridge," February 17, 2016; ATIP, Veterans Affairs Canada, "Human Resources Strategy," March 22, 2016.

${ }^{16}$ ATIP, Veterans Affairs Canada, "Vimy 100 Strategic Considerations," October 6, 2015.
} 
National Defence, the sound-and-light show, "[s]erve[d] as a reminder of how fortunate we are to call Canada home."17

The unveiling of a new education centre at the Vimy site was another important centennial project. In 2013, the Canadian government under Stephen Harper announced a donation of $\$ 5$ million for the building of a new educational centre at Vimy Ridge to replace its tired tourism kiosk. ${ }^{18}$ This donation was matched by an organization called the Vimy Foundation, which spearheaded the project. The new education centre was opened in April 2017 as part of the Vimy 100 festivities. The Vimy Foundation also commissioned a centennial park, opened to the public on November 9, 2018. ${ }^{19}$

Between November 8 and 12, 2017, VAC held official ceremonies to commemorate the Battle of Passchendaele. On November 8, ceremonies were planned at the St. Julien (Brooding Soldier) Memorial, John McCrae Memorial, and Essex Farm Cemetery. On November 9, a ceremony was held at Hill 62 (Sanctuary Wood) Canadian Memorial and a vigil at the Passchendaele Memorial. On November 10, a ceremony was held at Tyne Cot Cemetery. On the $11^{\text {th }}$, a Remembrance Day ceremony and a sunset ceremony were conducted. And finally, the Alex Decoteau Remembrance Run occurred, an event that honoured the Red Pheasant First Nation Cree track athlete and police officer

\footnotetext{
${ }^{17}$ The show is called "Three Seconds of Light" because it was meant to exhibit what can happen in three seconds to "change your day, your life, and your country." It was also adapted from the popular Northern Lights sound and light show displayed on Parliament Hill in Ottawa every summer. "Canadian produced sound and light show featured in Arras, France as part of Vimy 100 commemorative activities," Veterans Affairs Canada, March 24, 2017, https://www.newswire.ca/news-releases/canadian-produced-sound-andlight-show-featured-in-arras-france-as-part-of-vimy-100-commemorative-activities-617034854.html.

${ }_{18}$ ATIP, Christina Gaudet, email to Lynn MacDonald, May 8, 2013.

19 "Vimy Foundation Centennial Park," The Vimy Foundation, November 5, 2018, https://www.vimyfoundation.ca/the-vimy-foundation-centennialpark/\#: : :text $=$ November $\% 205 \% 2 \mathrm{C} \% 202018$, the $\% 20$ first $\% 20$ of $\% 20$ its $\% 20$ kind.
} 
who died while a soldier at Passchendaele. ${ }^{20}$ Compared to Beaumont-Hamel and Vimy, the Passchendaele ceremonies were small; it was estimated that only forty Canadian veterans, parliamentarians, and youth were in attendance, as well as 150 Canadian Forces members. ${ }^{21}$ Other supplementary events held across the former Ypres Salient included the unveiling of the "Canada Gate" monument on Canadalaan, Crest Farm, and a special Last Post ceremony at Menin Gate that highlighted Canada's efforts in the Battle. ${ }^{22}$ In the wake of the large-scale commemorations of the previous two years, the 2018 schedule was comparatively light. For example, a search for the hashtag \#Canada100Days on Twitter indicates that a small Historic Sites and Monuments Board of Canada (HSMBC) plaque was unveiled by Parks Canada in Cambrai on October 9, 2018 spearheaded by Parks Canada, and then Minister of Veterans Affairs, Seamus O'Regan, joined Prince Laurent of Belgium to watch the Liberation Parade in Mons on November 11, 2018. VAC's website also indicates a commemorative ceremony and unveiling of the George Price Monument occurred on November 10, 2018 in Mons. ${ }^{23}$ On the same day, Prime Minister Justin Trudeau attended a special Remembrance Day

\footnotetext{
${ }^{20}$ VAC's website encouraged people to participate on October 30 (the day Decoteau was killed in action), November 8 (National Aboriginal Veterans Day), November 10 (the end of the Battle of Passchendaele), and November 11 (Remembrance Day) as well. "Alex Decoteau Remembrance Run, Walk or Wheel," Veterans Affairs Canada, October 27, 2020, https://www.veterans.gc.ca/eng/remembrance/informationfor/educators/learning-modules/passchendaele/run-to-remember/alex-decoteau-run; ATIP, Veterans Affairs Canada, "2017 Commemorative Events Status Report," August 2016.

21 " $100^{\text {th }}$ Anniversary Battle of Passchendaele," The Governor General of Canada, November 3, 2017, https://www.gg.ca/en/media/news/2017/100th-anniversary-battle-passchendaele; "Canadian Army wellrepresented at the $100^{\text {th }}$ anniversary of the Battle of Passchendaele," National Defence, November 9, 2017, https://www.canada.ca/en/department-national-defence/news/2017/11/canadian_army_wellrepresentedatthe100thanniversaryofthebattleof.html.

${ }^{22}$ The Canada Gate mimics the "Last Steps Memorial Arch" in Halifax. Thomas Daigle, "The sights of Passchendaele, 100 years later," CBC News, November 10, 2017, https://www.cbc.ca/news/canada/thesights-of-passchendaele-100-years-later-1.4396297.

${ }^{23}$ George Price is believed to be the last Canadian soldier killed in battle during the First World War. "Commemorative ceremony and unveiling of the George Price Monument," Veterans Affairs Canada, February 12, 2019, https://www.veterans.gc.ca/eng/events/details/10275.
} 
ceremony at the Tomb of the Unknown Soldier in Paris accompanied by over sixty heads of state. ${ }^{24}$

As the above preamble signifies, the centenary of the First World War was comprised of many individual events, facilitated as a result of the cooperation of many stakeholders, including federal government departments, non-profit organizations, veterans' associations, foreign governments, and several memorial sites. Though this elaborate summary of centennial events is by no means exhaustive, it provides a glimpse into the kinds of relationships that a large-scale national commemoration entail. Looking at many of these events, and the relationships that assisted in their fruition, I began to understand commemoration as more than an act performed by a monolithic governing body, and more as fragmented, relational processes, or what I call in this dissertation, "commemorative assemblages." These insights not only come from the evidence presented in the coming pages but were also sparked by my own commemorative encounters.

I experienced a small fraction of the centenary. At 9:30 a.m. on November 11, 2018, I joined the already-large crowd forming around Ottawa's National War Memorial in anticipation of the start of the annual Remembrance Day ceremony. This ceremony was particularly special as it was to mark the hundredth anniversary of the end of the First World War. From where I stood with the sun beaming down, I could see the

\footnotetext{
${ }^{24}$ David Akin, "Analysis: PM Trudeau is in France this Remembrance Day, just as he should be," Global News, November 10, 2018, https://globalnews.ca/news/4650960/analysis-pm-trudeau-is-in-paris-thisremembrance-day-just-as-he-should-be/; John Leicester, Raf Casert, and Lori Hinnant, "World leaders gather in Paris to mark end of First World War, to renew promise of peace," The Associated Press, November 11, 2018, https://globalnews.ca/news/4652566/world-leaders-paris-armistice-peace/.
} 
memorial, though it was approximately 350 metres away. Then the parade began. I strained to get a good view of the goings-on. I noticed my cold feet as I continually went up on my toes to see around the small children hoisted on their parents' shoulders. Finally, as the ceremony started, I was pushed closer by the voluminous crowd of commemorators that formed behind me since I arrived. Governor General Julie Payette approached the memorial, hats were removed, the national anthem sounded, and the Last Post was trumpeted in as the crowd stood for a moment of silence. Cannons were fired, wreaths were laid, and speeches were given. Then, once it was over, the crowd dispersed. Some approached the memorial to remove their felt poppies and lay them on the Tomb of the Unknown Soldier, while others walked away. On this, the centenary of the Armistice, I stood off to the side and watched crowds of people remove their poppies, place them carefully on the memorial, and gaze upon the wreaths with heads lowered.

By this point in my graduate work, I had been studying the centenary for a year. There was a certain materiality in what I witnessed, and I was fascinated by it. The sacredness of the poppy and the wreaths, the enduring familiar traditions of the moment of silence, the sound of the Last Post. All these elements signal a commemoration independently, but this was a unique opportunity to see a federal collaboration. This was commemoration at work. However, as I stood there on the corner of Laurier and Elgin, I pondered what it meant to commemorate and why I felt I had to be on location, or "in place," even though I knew I would have had a better view of it all from the couch at home. Who and what was behind all this?

Six months later, on my lunch break from work, I decided to take a detour on my way back from my favourite lunch spot and walk past the National War Memorial. I had 
not seen it since the Remembrance Day ceremony. It was bare. No wreaths, no poppies, just two guards standing tall next to the memorial. Then, as I walked down the cobblestone promenade approaching the memorial, I looked down to notice a felt poppy, trodden on amidst several cigarette butts, discarded as trash (Figure 1.1). How could something viewed as sacred enough to be laid on a memorial six months ago now suddenly find itself discarded and stomped on?

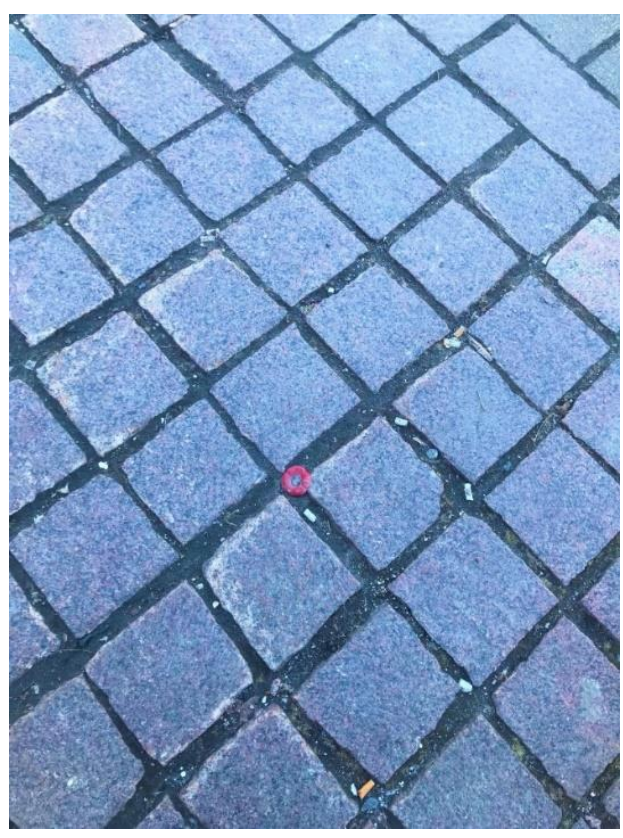

Figure 1.1 - Image of a felt poppy, dirtied by foot traffic in downtown Ottawa. Photograph taken by Breanna Lester, April 2018.

I was far from a neutral observer on that November 11. By 2018, I was two years into this project and had read extensively in literatures related to public history and commemoration, and my experiences were mediated by that scholarly work. Though Remembrance Day 2018 was not the first (or last) commemorative event I would experience, it did affirm much of the way I had begun conceptualising commemoration as 
a term and a process when I began my doctoral work in 2016 . The materiality, emotional investment, and ephemerality were each prominent on this November 11.

This dissertation seeks answers to the following questions: How do commemorations work? Who or what is involved in the realization of these commemorative moments? And, can we look beyond established definitions of commemoration as an upholder of nationalism, identity, and collective memory to locate a more fulsome, nuanced understanding? In pursuit of answers to these questions, and deploying a range of methodologies, this dissertation repositions the centenary of the First World War as an assemblage of things, people, and ideas that affect, sometimes deeply and profoundly, those who experience them, but especially those who conduct the behind-the-scenes labour that make commemorations happen. Using the centenary of the First World War as a case study, this project aims to reimagine commemorations as constantly evolving, unfinished human processes that are comprised of many things, people, and ideas. In other words, this dissertation is focussed on commemorative practices.

Scholarly definitions of "commemoration" reveal that this dissertation's focus on practice is atypical. In a literature review on commemoration's historiography, American scholar Kirk Savage writes: "dictionary definitions tell us that to commemorate is to "call to remembrance,' to mark an event or a person or a group by a ceremony or an observance or a monument of some kind. Commemorations might be ephemeral or permanent; the key point is that they prod collective memory in some conspicuous way." ${ }^{25}$ British memory scholar Jay Winter defines commemoration as, "publicly

${ }^{25}$ Kirk Savage, "History, Memory, and Monuments: An Overview of the Scholarly Literature on Commemoration," University of Pittsburgh, https://www.nps.gov/parkhistory/resedu/savage.htm. 
performed acts of remembrance defined by a politically sanctioned script." ${ }^{26}$ Writing on the South African commemoration of apartheid, Martin J. Murray further identifies commemoration as "a specific kind of history-making process that aims to promote and secure particular interpretations of past events while impeding and erasing potentially divergent or rival readings. ${ }^{27}$ American John Bodnar argues that governments use national commemorations as a "distortion of the past." 28 Peter H. Akyroyd argues that while commemorations imply a connection to or reflection of the past, they are intended more for the present and future. ${ }^{29}$ In his history of the commemoration of Quebec's tercentenary, Viv Nelles positions commemoration as an "act of self-invention." 30 And most recently (2017), writing on the centennial of Confederation in Nova Scotia, Meaghan Beaton posits that commemorations are highly-politicized "vehicles" used in the production of master narratives. ${ }^{31}$

As demonstrated by these scholars, there is a lack of a single, encompassing definition of commemoration, though together, most seem to agree that commemoration is a political act that involves some form of nation-building, is often used to maintain national identities, and forge a collective memory. The Canadian scholars who have written about commemoration in the last five years echo this. In 2016 and 2018, Matthew

${ }^{26}$ Jay Winter, Remembering War: The Great War Between Memory and History in the Twentieth Century (New Haven: Yale University Press, 2006), 31.

${ }^{27}$ Martin J. Murray, Commemorating and Forgetting: Challenges for the New South Africa (Minneapolis: University of Minnesota Press, 2013), ix.

${ }^{28}$ John Bodnar, Remaking America: Public Memory, Commemoration, and Patriotism in the Twentieth Century (Princeton: Princeton University Press, 1992), 182.

${ }^{29}$ Peter H. Akyroyd, The Anniversary Compulsion: Canada's Centennial Celebrations, A Model MegaAnniversary (Toronto: Dundurn Press, 1992), 4.

${ }^{30}$ H.V. Nelles, The Art of Nation-Building: Pageantry and Spectacle at Quebec's Tercentenary (Toronto: University of Toronto Press, 1999), 12.

${ }^{31}$ Meaghan Beaton, The Centennial Cure: Commemoration, Identity, and Cultural Capital in Nova Scotia During Canada's 1967 Centennial Celebrations (Toronto: University of Toronto Press, 2017), 17. 
Hayday and Raymond B. Blake published a two-volume study titled Celebrating Canada, the first on "holidays, national days, and the crafting of identities" and the second on "commemorations, anniversaries, and national symbols." Collectively, both volumes largely rely on a foundation of literature on nationalism and identity, and focus on anniversaries of Canada's Confederation to argue that "nationalism and identity are powerful shapers of societies, and they are reinforced by commemorative events and national symbols. ${ }^{32}$ Cecilia Morgan's Commemorating Canada: History, Heritage, and Memory, 1850s-1990s (2016) looks at how commemorations operate in constraining the kinds of stories that are told and work to suggest ways of re-inserting 'new' stories into historical metanarratives. She asserts that commemorations are "cultural processes" that occur simultaneously with nation-building. ${ }^{33}$ While Morgan is critical of commemoration and is successful in interrogating how commemorations operated historically (her study ends in the 1990s), her project is largely concerned with the relationship between commemoration and nationalism. Furthermore, though Morgan devotes a whole chapter to World War commemorations, like Hayday and Blake's collections, she relies heavily on similar secondary literature to pursue answers to the questions: "why, when, where, and for whom is the past meaningful?"34

\footnotetext{
${ }^{32}$ Matthew Hayday and Raymond Blake, Celebrating Canada: Commemoration, Anniversaries, and National Symbols (Toronto: University of Toronto Press, 2018), 380. Hayday and Blake consult coveted nationalism/identity literature including Eric Hobsbawm and Terence Ranger, eds., The Invention of Tradition (Cambridge: Cambridge University Press, 1983); Michael Kammen, Mystic Chords of Memory: The Transformation of Tradition in American Culture (New York: Vintage Books, 1993); David Lowenthal, The Past is a Foreign Country (Cambridge: Cambridge University Press, 1985); Pierre Nora and Lawrence D. Kritzman, eds., Realms of Memory: Rethinking the French Past (New York: Columbia University Press, 1996-1998); and Mark Salber Phillips and Gordon Schochet, eds., Questions of Tradition (Toronto: University of Toronto Press, 2004).

${ }^{33}$ Cecilia Morgan, Commemorating Canada: History, Heritage, and Memory, 1850s-1990s (Toronto: University of Toronto Press, 2016), 8, 46.

${ }^{34}$ Morgan, Commemorating Canada, 184.
} 
The centenary saw the publication of several commemorative books, including Ian McKay and Jamie Swift's The Vimy Trap, Or How We Learned to Stop Worrying and Love the Great War (2016) followed by Tim Cook's Vimy: The Battle and the Legend (2017). McKay and Swift's The Vimy Trap is a polemic examination of a phenomenon they refer to as "Vimyism," or the act of "seeing one battle as Canada's birthplace, or a turning point in the war, or the Great War itself as a seminal Canadian moment." ${ }^{35}$ McKay and Swift blame popular figures such as Don Cherry and Pierre Berton, but also academic scholars, for popularizing Vimy mythology. Though McKay and Swift ultimately argue against the championing of "Vimyism," they in effect amplify their own form of nationalism. The Vimy Trap is in many ways a continuation of work they began in their prior book, Warrior Nation: Rebranding Canada in an Age of Anxiety (2012) in which they argue that Canada, largely under Stephen Harper's administration, was rebranded as a nation built through a military past. ${ }^{36}$ In both books, McKay and Swift maintain that Canada is not militaristic, but rather a country of peacekeepers, and though their conclusion to The Vimy Trap cautions readers not to succumb to these nationalist mythologies and focus on the Great War as international conflict, they effectively promote their version of nationalism predicated on Canadians-as-peacekeepers mythology. ${ }^{37}$

Tim Cook's Vimy is an examination of how Vimy was "reconstructed, reframed, and reimagined over the years." ${ }^{" 38}$ Though Cook acknowledges that Canada "was not born

\footnotetext{
${ }^{35}$ Ian McKay and Jamie Swift, The Vimy Trap, Or How We Learned to Stop Worrying and Love the Great War (Toronto: Between the Lines, 2016), 69.

${ }^{36}$ Ian McKay and Jamie Swift, Warrior Nation: Rebranding Canada in an Age of Anxiety (Toronto: Between the Lines, 2012), 9.

${ }^{37}$ McKay and Swift, The Vimy Trap, 269.

${ }^{38}$ Tim Cook, Vimy: The Battle and the Legend (Toronto: Penguin Random House, 2017), 2.
} 
on the Ridge," he does maintain that the First World War is "an important symbol."39 McKay and Cook disagreed publicly after the release of their books, notably on a 2017 episode of The Agenda With Steve Paikin during which McKay accused Cook of "putting a happy face on a holocaust.” While Cook opposed, he also respectfully disengaged. ${ }^{40}$ Like their scholastic counterparts, both McKay and Swift, and Cook examine commemoration as a performative act of identity and nationalism. There is little in this Canadian literature, though, about how First World War commemorative moments unfolded as planned and administered events, and about the people who did this work.

In memory studies, though, there is literature that informs how practice is studied and understood in this dissertation. In 1925, Maurice Halbwachs defined "collective memory" as memory that is not a given, but a social construction, and not a "mystical group mind." ${ }^{41}$ In his formulation, remembering comes from social groups including the family, religious communities, and social classes. Individuals do not remember on their own, but rather their memory is formed through group experience which differs from the collective experience (memory) of other groups. ${ }^{42}$ To Halbwachs, memory and history are different. Memory is lived experience, whereas history is a list of dates or an abstract knowledge of the past. ${ }^{43}$ In The Texture of Memory (1993), James Young uses monuments as meeting places for "collected memory." Playing off Halbwachs' "collective memory," "collected memory" invites diversity and fragmentation into what Young sees as Halbwachs' static concept; "collected memory” is the idea that there are

\footnotetext{
${ }^{39}$ Cook, Vimy, 6.

40 The Agenda with Steve Paikin, "A Century After Vimy," TVO, April 12, 2017.

${ }^{41}$ Maurice Halbwachs, On Collective Memory (Chicago: University of Chicago Press, 1992), 22.

${ }^{42}$ Halbwachs, On Collective Memory, 52, 67.

${ }^{43}$ Halbwachs, On Collective Memory, 118.
} 
"many discrete memories that are gathered into common memorial spaces and assigned common meanings." ${ }^{44}$ Like "collective memory," "collected memory" is shared among groups, though it does not assume that each person within the collective shares the same version of the shared memory with all other members of the same group. Young rejects the idea that memorials are simply art and, instead, refers to monuments as "memorial representations of history" that influence the "course of ongoing events." 45

In Multidirectional Memory (2009), Michael Rothberg also takes issue with the limits of "collective memory" as competitive memory and instead discusses shared memory as also "multidirectional." ${ }^{46}$ Thinking about different social groups" histories of victimization, Rothberg advocates for the idea that memory is not a "zero-sum struggle over scarce resources," but rather "multidirectional [:] subject to ongoing negotiation, cross-referencing and borrowing." ${ }^{, 47}$ In a decolonizing, post-Holocaust, post-World Wars world, many traumatic memories mingle together in public space. Rothberg maintains that no single traumatic memory is unique, and through attributing a uniqueness to traumatic events such as the Holocaust, a hierarchy of suffering is created. This hierarchy is problematic in deciding commemorative initiatives. ${ }^{48}$ Rothberg and Young are examples of memory scholars and public historians who look to break away from older theoretical models and concepts such as "collective memory" to make sense of sites, people, events, practices, and materialities associated with remembering the past in public

\footnotetext{
44 James E. Young, The Texture of Memory: Holocaust Memorials and Meaning (New Haven: Yale University Press, 1993), xi.

${ }^{45}$ Young, The Texture of Memory, 12.

${ }^{46}$ Rothberg, Multidirectional Memory, 3.

${ }^{47}$ Michael Rothberg, Multidirectional Memory: Remembering the Holocaust in the Age of Decolonization (Stanford: Stanford University Press, 2009), 3.

${ }^{48}$ Rothberg, Multidirectional Memory, 9.
} 
spaces. ${ }^{49}$ Young's and Rothberg's reimagining of "collective memory" as less of a static taken-for-granted concept, and more as fragmented experiences has been especially useful for this dissertation because they call attention to the uneven ways that commemorative events are created and experienced.

Cultural anthropologist Sharon Macdonald's Memorylands (2013) offers an invaluable synthesis to the memory studies literature through what she refers to humourously as "an addition to the memory mountain." ${ }^{50}$ Rather than sticking to one form of memory (collective, multidirectional, collected) Macdonald prefers to study memory as part of a "complex" that "comprises different elements, woven more or less loosely together. It also has a propulsion towards further encompassment partly through offering what becomes an increasingly taken-for-granted form of comprehending and experiencing." In Memorylands, Macdonald argues that "the memory complex can be seen $[\ldots]$ as an assemblage of practices, affects and physical things, which include such parts as memorial services, nostalgia and historical artefacts." ${ }^{51}$ In her words, assemblage theory, "insists that we be wary of taking particular objects or categories for granted and that to do this we should investigate specific instances [to] recognise the potential variety of forms that a wider term might designate." In her own empirical case studies of heritage projects, Macdonald uses assemblage theory to investigate the "materialisation of

\footnotetext{
${ }^{49}$ Though Young and Rothberg's works are most pertinent to this dissertation, there are many other scholars who have produced critical works of "collective memory" that influenced my thinking, including: Svetlana Boym, The Future of Nostalgia (New York: Basic Books, 2001); Andreas Huyssen, Present Pasts: Urban Palimpsests and the Politics of Memory (Stanford: Stanford University Press, 2003); Alison Landsberg, Prosthetic Memory: The Transformation of American Remembrance in the Age of Mass Culture (New York: Columbia University Press, 2004); and Marianne Hirsch, The Generation of Postmemory: Writing and Visual Culture after the Holocaust (New York: Columbia University Press, 2012).

${ }^{50}$ Sharon Macdonald, Memorylands: Heritage and Identity in Europe Today (New York: Routledge, 2013), 7.

${ }^{51}$ Macdonald, Memorylands, 6.
} 
memory in heritage" and "characterise processes and patterns," something that echoes in my own attention to practice, work, and affect in the First World War centenary. ${ }^{52}$

Beyond a consideration of the relationships between seemingly disparate entities, assemblage theory also takes the energies of both human and nonhuman entities into consideration. Political theorist and philosopher, Jane Bennett evokes assemblage to assist in describing what she calls "thing power." ${ }^{53}$ In Vibrant Matter (2010), Bennett maintains that "edibles, commodities, storms, and metals act as quasi agents, with their own trajectories, potentialities and tendencies." ${ }^{, 54}$ She describes assemblages as, "ad hoc groupings of diverse elements, of vibrant materials of all sorts. Assemblages are living, throbbing confederations that are able to function despite the persistent presence of energies that confound them from within." ${ }^{, 55}$ Furthermore, Bennett is cognizant of essentializing categories and therefore argues that an assemblage represents an intermingling of human and nonhuman: "its efficacy or agency always depends on the collaboration, cooperation, or interactive interference of many bodies and forces. ${ }^{, 56}$ As an amalgam of powerful entities, assemblages remain uneven. Bennett suggests that: "some of the points at which the various affects and bodies cross paths are more heavily trafficked than others, and so power is not distributed equally across its surface." 57 Bennett's and other assemblage scholars' works effectively facilitate open discussions and considerations of what is possible when studying the relationships between animate and inanimate entities. In this dissertation, assemblage also assists us in understanding the

\footnotetext{
52 Ibid.

53 Jane Bennett, Vibrant Matter: A Political Ecology of Things (Durham: Duke University Press, 2010), $\mathrm{xvi}$.

54 Bennett, Vibrant Matter, viii.

55 Bennett, Vibrant Matter, 23-24.

${ }^{56}$ Bennett, Vibrant Matter, 21.

${ }^{57}$ Bennett, Vibrant Matter, 24.
} 
nonhuman components of First World War commemoration, including the historic sites and monuments that are integral to how commemorations work. It also aids our understanding of the power these seemingly inanimate things have in affecting other nonhuman and human interactions. ${ }^{58}$

Public historians and heritage scholars have just begun to employ assemblage theory. For example, in Tiina Roppola, Jan Packer, David Uzzell, and Roy Ballantyne's 2019 article examining the interactions between migrants and the Australian War Memorial (AWM), they use a combination of interviews and assemblage theory to argue that there are always multiple assemblages at work at any given point of contact. Their eleven participants, drawn from a pool of ninety-three visitors, collectively assist the authors in understanding the relationships between these migrants and the AWM. ${ }^{59}$ They conclude that "a heritage visitor is not only in assemblage with a particular heritage site on a given day. They are also in assemblage with any number of other assemblages, which together bear influence on emergent meanings, experiences, and identities." ${ }^{\circ 0}$ This dissertation finds value in not only looking at the centenary commemorations of the First World War as a singular assemblage, but rather of many assemblages intersecting and interacting with each other. The assemblages explored in this dissertation include the where of commemorations (the landscapes, spaces and places they occur), the quotidian

\footnotetext{
${ }^{58}$ I first considered framing this dissertation using Bruno Latour's Actor-Network Theory (ANT) which he lays out well in Reassembling the Social: An Introduction to Actor-Network Theory (Oxford: Oxford University Press, 2005). Though ANT's empirical approach does well in understanding the "durability of social ties," it does not consider as well the intangibility of entities like emotions. Martin Müller's "Assemblages and Actor-networks: Rethinking Socio-material Power, Politics and Space," Geography Compass 9, 1 (2015): 27-41.

${ }^{59}$ Tiina Roppola, Jan Packer, David Uzzell, and Roy Ballantyne, "Nested assemblages: migrants, war heritage, informal learning and national identities," International Journal of Heritage Studies 25, 11 (2019): 1210.

${ }^{60}$ Roppola, Packer, Uzzell, Ballantyne, "Nested Assemblages,” 1220.
} 
bureaucratic processes involved in constructing and performing these events, and the people (federal public servants, adjacent stakeholders, and battlefield tour professionals) behind-the-scenes doing so much commemorative labour.

Working with assemblage theory requires a range of methods to make sense of a variety of evidence, and here Sharon Macdonald's practice is as inspiring as her theory. Drawing from historical, memory, cultural, and anthropological methods, Macdonald employs what she calls "methodological pluralism," using "oral histories, semi-structured interviews, spatial mapping, photography, film-making and other visual and sensory methodologies, as well as textual analysis, and sometimes also surveys" to support her argument that there is a "complex of ways of doing and experiencing the past" through "a repertoire of tendencies and developments. ${ }^{\circ 1}$ In my own work, I did not begin my research with a singular way in which I was going to interpret my archive, but rather I employed assemblage theory as a sensibility to make sense of what I was seeing in the evidence I collected.

This dissertation draws on three core methods: Access to Information and Privacy (ATIP); interviews; and ethnography. My analysis of approximately 8000 pages of material requested through ATIP assisted me in forming a commemorative map of practices, concerns, and a list of informed interview questions. I then crafted a survey using Qualtrics on commemorative experience that was disseminated through social media and socially networked contacts to locate and interview fifteen commemoration professionals. ${ }^{62}$ Lastly, with interviews nearly complete, I conducted ethnographic fieldwork on the former First World War battlefields in France and Belgium to add

${ }^{61}$ Macdonald, Memorylands, $2,9$.

${ }^{62}$ A list of my survey questions is appended to this dissertation. 
perspective to the stories I recorded in the interviews and the practices I observed in the ATIP documentation. I will now address each of these elements, briefly, to show how they interconnected but also how each stage required a different methodological positioning.

Access to Information and Privacy (ATIP)

Access to Information and Privacy (ATIP) material has often been referred to by scholars as a "backstage" perspective on government processes. ${ }^{63}$ However, as sociologist Dominique Clément argues in a 2015 article titled, “'Freedom' of Information in Canada: Implications for Historical Research," most historians shy away from the ATIP process even though there exists a "rich and untapped source for historical research. ${ }^{94}$ Though, as I discovered through my own experience using ATIP, there are reasons for this.

Before an ATIP request is submitted, there is a process of drafting correctly worded request forms and undergoing negotiations with the ATIP officer assigned to the file. As Walby and Larsen suggest,

The wording of the request is what the ATI/FOI [Access to Information/Freedom of Information] coordinator in any government agency uses to task an office of primary interest to search for records [.... The issue with the wording of requests gets trickier, since the terminology that academics associate with government practices does not always reflect the internal vocabulary of such agencies. ${ }^{65}$

\footnotetext{
${ }^{63}$ Farzana Nanji Jiwani and Tamara Krawchenka, "Public Policy, Access to Government, and Qualitative Research Practices: Conducting Research within a Culture of Information Control," Canadian Public Policy 40, 1 (2014): 59; Kevin Walby and Mike Larsen, "Access to Information and Freedom of Information Requests: Neglected Means of Data Production in the Social Sciences," Qualitative Inquiry 18(1), 2011: 33 .

${ }^{64}$ Dominique Clément, “"Freedom' of Information in Canada: Implications for Historical Research” Labour/Le Travail 75 (2015): 101.

${ }^{65}$ Walby and Larsen, "Access to Information and Freedom of Information Requests," 35. I was grateful for the advice and assistance from Carleton's public servant-in-residence, Jean-Pierre Morin who helped me craft my requests to yield the results I desired.
} 
And, according to Walby and Larsen, a lack of terminology to support the first request often necessitates a second, follow-up request. ${ }^{66}$

I also struggled to decide which departments I needed to solicit for information. I knew from the beginning that it would be necessary to submit requests to Veterans Affairs Canada (VAC), Canadian Heritage (PCH), and Department of National Defence (DND) because looking at stakeholders of national events showed that they appeared to be the most involved in centenary events. I also knew from preliminary research that the Commemoration Order 1965-688 states that it is the responsibility of VAC to conduct remembrance ceremonies outside Canada.$^{67}$ In conversation with Public Servant- InResidence at Carleton University, Jean-Pierre Morin, I also learned that Indigenous and Northern Affairs Canada (INAC now known as Crown-Indigenous Relations and Northern Affairs Canada (CIRNAC)) also had an archive of material related to the centenary. With his assistance, I also sent a request to them.

After a request is submitted, an ATIP officer is assigned to the file. One of these officer's first tasks is to communicate with the researcher to clarify language and, as Walby and Larsen point out, to negotiate wording of the request, sometimes with the intention of "scuttling the request, but most often because they themselves or the office of primary interest is unsure how to respond. ${ }^{\prime 68}$ This is why it is important to build a rapport

\footnotetext{
${ }^{66}$ Walby and Larsen, “Access to Information and Freedom of Information Requests,” 35.

${ }^{67}$ Order in Council of Canada, 1965, Commemoration Order of 1965, P.C. 1965-788.

${ }^{68} \mathrm{Ibid}$. I received phone calls from every department I submitted my requests to within a week of my submissions. Each department clarified what kinds of records I desired. There is a specific language one has to understand to obtain the necessary information from the Canadian government. I was asked many difficult questions for a student who had only begun thinking about the minutiae of her research methodology at the time the requests were submitted in late 2016 and early 2017 such as "Will you require drafts or finalized versions of our records?" as well as "Are you interested in financial documents, as well as briefing notes, emails, and reports?"
} 
with the officer. ${ }^{69}$ Once the request is adequately worded, the officer in charge facilitates the process of locating material. ${ }^{70}$

Clément attributes much of historians' reticence in using ATIP to "excessive government secrecy" leading to a lack of transparency, delays in returning requests, and excessive fees. ${ }^{71}$ When Justin Trudeau and his Liberal government took federal office in late 2015, they promised to reform ATIP to provide more transparency to interested members of the population. However, according to a 2017 Globe and Mail article by Laura Stone, things seem to have worsened. Stone's reporting suggests the system worked better under the Harper administration and that, according to News Media Canada, the issue of timely disclosure of information had not improved since $2015 .^{72}$

Beyond a complicated submission process and delays in retrieving information, there is also a process of altering and redacting information that occurs before the researcher obtains the requested material. Writing of his own experience collecting ATIP records, Clément reminds readers of the fragility of the ATIP archive, and officials' power in destroying and redacting records arbitrarily. He posits that the destruction of records is most common with local police or court records, and the decision to redact records follows a pattern. Clément writes:

\footnotetext{
${ }^{69}$ Walby and Larsen, "Access to Information and Freedom of Information Requests," 35. I also built rapport with the ATIP officer at VAC assigned to my request which later assisted me in gaining contact information for the 4 VAC personnel I interviewed.

${ }^{70}$ Though a disclaimer on the confirmation letter I received clearly states that it is the responsibility of the solicited department to return requests within 30 days, all my requests were projected delayed by 90 days. An appendix to this dissertation shows that it actually took a year or longer to receive the requested material.

${ }^{71}$ Clément, “'Freedom' of Information in Canada: Implications for Historical Research,” 102. For this project, I spent $\$ 5$ per request, $\$ 20$ in total.

${ }^{72}$ Laura Stone, "Canada's access-to-information system has worsened under Trudeau government: report," Globe and Mail, September 27, 2017, https://www.theglobeandmail.com/news/politics/canadas-access-toinformation-system-has-worsened-under-trudeau-government-report/article36407309/. Though this was my first experience submitting ATIP requests, the delays I experienced certainly support the Globe and Mail opinion.
} 
The most common exemptions in Canada include crown corporations or executive branch records; cabinet confidences and legal opinions; third-party business information; personal information; information shared by other governments; and any documents that might prove harmful to public safety, law enforcement, economic interest, or heritage sites. ${ }^{73}$

In other words, though it may seem like scholars who use ATIP receive a treasure trove of never-before-seen evidence, the completed request has undergone a rigorous process of selection before it is released to the researcher which leaves the scholar with an imbalanced archive. Clément also argues that there exists a certain level of inconsistency in Government officials' redaction of materials; one official may redact something another would not. ${ }^{74}$ This essentially means that with ATIP, the quality of the material that is received by the researcher is dependant on who was responsible for the redactions. $^{75}$

However, using ATIP is crucial for researchers, such as myself, who seek an insider perspective into government processes. Recognizing this, Clément concludes his article by listing recommendations for historians and ATIP officers to consider if transparency is to truly exist in government and attract scholars to this relatively untapped resource. Among these recommendations are three that I wish to highlight here. The first is mitigating the delays experienced by scholars attempting to obtain ATIP material in time to complete research on a given topic. In his own experience obtaining

\footnotetext{
${ }^{73}$ Clément, “'Freedom' of Information in Canada: Implications for Historical Research,” 105; I would add information on events that have not yet occurred to this exhaustive list. This comes from advice I received from the ATIP officers at Veterans Affairs I spoke to while completing my requests. As it happens, ATIP Officers are not allowed to release information on events that are upcoming, so I had to resubmit a request for information on Vimy 100 after the event had taken place.

${ }^{74}$ Clément, “"Freedom' of Information in Canada: Implications for Historical Research,” 105.

${ }^{75}$ Relating to my own experience with ATIP, I would say that approximately a third of the records I received from ATIP contained some sort of redaction. Common redactions were names of third-party persons or organizations, contact information for public servants who are no longer associated with the department, and any other potentially sensitive information. In the end, I was grateful for the approximately 8000 pages of material I received.
} 
Olympic records, Clément noted that it took two years before he received any records and a total of six years to complete his request. ${ }^{76}$ Second, Clément recommends waiving ATIP fees. ${ }^{77}$ For historians specifically, Clément also recommends additional training in the seemingly complicated art of submitting and obtaining ATIP requests and returns. $\mathrm{He}$ states that it "should be a component of all history graduate programs in Canada." ${ }^{178}$ As Walby and Larsen argue, submitting ATIP requests is necessary because they, "provide a partial entrance into a little know realm of texts that are crucial to understand how government organizations operate [.... Use of [ATIP] provides a unique perspective for scholars who are trying to conceptualize how government agencies work in action." ${ }^{79}$ As a scholar of commemoration policy, and given the current nature of my work, it was therefore crucial for me to utilise ATIP to begin understanding how events are prioritised, who and what are involved in actualising them, and what is involved in the aftermath of the events. Though the ATIP material was invaluable to the project, it soon became apparent that there were missing perspectives. It was at that point I decided to solicit information and opinions from the public servants and key stakeholders who worked to actualise the commemorative events I was reading about in the ATIPs. ${ }^{80}$

\footnotetext{
${ }^{76}$ Clément, "'Freedom' of Information in Canada: Implications for Historical Research," 107. For scholars doing a master's degree or other project with tight time constraints, it would be impossible to use ATIP with wait times where they are. I was grateful for the time allotted to complete doctoral work, though I was less confident in the kinds of material I wanted when I had to submit my requests in early 2017. I could have benefited from more time.

${ }^{77} \mathrm{Ibid}$. Though in total I spent only $\$ 20$ to process my requests, I never did receive completed returns from Canadian Heritage (PCH) or the Department of National Defence (DND).

${ }^{78}$ Clément, "“Freedom' of Information in Canada: Implications for Historical Research," 119.

${ }^{79}$ Walby and Larsen, "Access to Information and Freedom of Information Requests," 39.

${ }^{80} \mathrm{~A}$ "How-To" guide to navigating the ATIP process is appended to this dissertation.
} 


\section{$\underline{\text { Interviews }}$}

As Jiwani and Krawchenko argue, "[i]n-depth interviews with public servants are a critical research method in the study of government. Historical and institutional factors, and the informal internal dynamics that influence policy, require a depth of understanding that is often best investigated through such methods." 81 Given that the policy documents I received through ATIP contained several redacted pages, and were often final versions, I wanted to know more about the process of executing commemorations, including the "informal internal dynamics" that Jiwani and Krawchenko describe.

To start, I obtained permissions from the Carleton University Research and Ethics Board (CUREB) to conduct research with human participants. Once I gained clearance, I created a survey using Qualtrics, a software employed by large companies to "collect, understand, and take action on experience data." ${ }^{\prime 2}$ I was then able to disseminate a callfor-participants and questionnaire on Facebook and Twitter in August 2018. ${ }^{83}$ From this survey, I received seventeen responses, eight of which expressed interest in being contacted for an interview. These potential participants were mainly located in Ontario, Nova Scotia, Newfoundland, and British Columbia. Facebook (The Canadian Centenary Project) and Twitter (@thecanadiancentenaryproject)pages served as sharing platforms for my project, and often resulted in tags to other potential interviewees. ${ }^{84}$ Though interviews with the eight willing participants would have been an informative experience,

\footnotetext{
${ }^{81}$ Farzana Nanji Jiwani and Tamara Krawchenko, "Public Policy, Access to Government, and Qualitative Research Practices: Conducting Research within a Culture of Information Control," Canadian Public History 40, 1 (2014): 57.

${ }^{82}$ Qualtrics XM: https://www.qualtrics.com/.

${ }^{83}$ See my list of survey questions appended to this dissertation.

${ }^{84}$ The Qualtrics survey was my attempt to gather a diverse pool of participants. Of the eight willing interview participants, none were federal public servants, and the majority were community project leaders or participants based in Ontario (four of eight were Ontario residents).
} 
they would not have assisted me in understanding the ATIP material as none of these respondents worked in the Federal Public Service. It was at this point that I decided to use the network I had already formed through the ATIP process and my own studies to attract the attention of the public servants I wanted to interview.

As an icon in the field of Canadian military history and commemoration, Tim Cook was an obvious choice for a first interview; I had read many of his books, written a paper about his centenary book, Vimy: The Battle and the Legend (2017), and had seen him speak at conferences and on television as part of televised commemorations. During our interview, Cook mentioned I should speak with his friend, Douglas Ballam (Marketing \& Communications Officer, Reservist, and Newfoundlander) who had planned a conference at Memorial University Cook had recently attended. He also linked me to another colleague, Steve Harris (Director - Directorate of History and Heritage). As Historian-in-Residence at Carleton University, CIRNAC's historian, Jean-Pierre Morin was also interested in discussing his department's participation in the centenary, so I interviewed him as well.

When I started this project, I endeavoured to tag along on a battlefield tour to gain insight into how people interacted with the former battlefields. However, as I continued through the interview process, I decided interviews prior to my own ethnographic experience would suffice. Accordingly, I located three battlefield tour companies on the internet. Of the three, representatives from two responded to my invitation (John Cannon and Phil Craig from Liberation Tours and Jérémie LeBlanc from the Canadian Battlefields Foundation). After speaking with LeBlanc, he provided me contact information for his colleague, David Patterson who, though he also conducted tours for 
the Canadian Battlefields Foundation, ran his own company, Fields of Fire Tours.

Patterson also accepted my invitation for an interview.

In addition, I conducted a personnel search for the public servants I read about in the ATIPs using the Government Electronic Directory Service (GEDS) and subsequently sent invitations to several personnel. However, I received no responses. Getting creative, I reached out to the ATIP contact I made at VAC during the retrieval process and asked if they would mind forwarding my invitation to any interested parties. This process assisted me in connecting with my remaining interviewees. I also solicited stakeholders that were discussed in the ATIPs, including Caitlin Bailey from the Vimy Foundation and R.H. Thomson from The World Remembers as they appeared to be key stakeholders in some of VAC's commemorative activities. And, coincidentally, through extended familial connections, I was able to identify Ocel Dauphinais-Matheson, the Visitor Experience Manager at Vimy. I found him on LinkedIn and scheduled a meeting at Vimy when my partner and I travelled there for research in October 2019.

In total, I interviewed fifteen commemoration professionals. ${ }^{85}$ A summary table of these participants appears in Table 1 at the end of this sub-section. Of these, three of fifteen were women, all were white, and though our interviews were conducted in English, most of the participants were bilingual. The audio-recorded interviews were conducted either in-person (seven) or on the phone (eight). The questions were asked using oral history techniques I derived from my own undergraduate training and Valerie Raleigh Yow's Recording Oral History (2014). Based on Appendix A in Yow's book, I

\footnotetext{
${ }^{85}$ Each of my interviewees consented to an interview, and to the use of their real names. Despite their candor, and consent to use anything they revealed to me during our interview, I chose not to include stories or insights that posed potential professional risk, especially if the information shared did not add anything of material value to this dissertation.
} 
prepared a list of open-ended questions in three sections: the first section focused on their background, schooling, and memories of commemorative activities in childhood; the second section discussed their centenary roles and challenges they experienced; Section Three asked participants to reflect on the centenary as a whole and share their thoughts on commemoration in general. ${ }^{86}$ All interviews took place between May 2019 and January 2020.

In listening to the work stories of commemoration professionals, I began to see commemorations less as spectacular events and more as laborious processes that affected the workers professionally, physically, and emotionally. My interviewees generously shared not only professional stories, but also deeply personal experiences with me. The stories I heard in these interviews seemed to complement those of Amy Tyson in her The Wages of History (2013). As an interpreter at historic Fort Snelling, Tyson experienced the seemingly minute changes to speech, mannerisms, and demeanors that occur when a person takes on the difficult role of interpreting historical space. ${ }^{87}$ At its core, Tyson's book looks at living history museum interpreters as both "service workers and cultural producers" as they perform interpersonal and emotional labour. ${ }^{88}$ Though Tyson does not explicitly mention use of an autoethnographic approach, her work is autoethnographic by virtue of the fact that she worked on site as an interpreter alongside her interviewees and wrote her own experiences into her book. My own ethnography, however, was somewhat different, but it also proved integral to my project.

\footnotetext{
${ }^{86}$ A list of these questions is appended to this dissertation.

${ }^{87}$ Amy Tyson, The Wages of History: Emotional Labor on Public History's Front Lines (Boston: University of Massachusetts Press, 2013), 110.

88 Tyson, The Wages of History, 4-5.
} 
Table 1: Table of Interviewees

\begin{tabular}{|c|c|c|c|}
\hline Name of Interviewee & Position(s) of Interviewee & Organization of Interviewee & Date / Place / Mode of Interview \\
\hline Tim Cook & Historian & Canadian War Museum & $\begin{array}{l}\text { May 30, } 2019 \text { / Canadian War } \\
\text { Museum, Ottawa / in-person }\end{array}$ \\
\hline Jean-Pierre Morin & Historian & $\begin{array}{l}\text { Indigenous and Northern Affairs Canada (INAC) / } \\
\text { Crown-Indigenous Relations and Northern Affairs } \\
\text { Canada (CIRNAC) }\end{array}$ & $\begin{array}{l}\text { July 5, } 2019 \text { / Carleton University, } \\
\text { Ottawa / in-person }\end{array}$ \\
\hline Douglas Ballam & $\begin{array}{l}\text { Veterans Services Program } \\
\text { Coordinator // Warrant Officer }\end{array}$ & $\begin{array}{l}\text { Memorial University of Newfoundland // Canadian } \\
\text { Armed Forces Reserves }\end{array}$ & July 27, 2019/ Phone \\
\hline Steve Harris & Director & Directorate of History and Heritage $(\mathrm{DHH})$ & $\begin{array}{l}\text { August } 1,2019 \text { / Directorate of } \\
\text { History and Heritage / in-person }\end{array}$ \\
\hline Caitlin Bailey & Executive Director & The Vimy Foundation & July 24, 2019 / Phone \\
\hline John Cannon & Co-Founder // Tour Director & Liberation Tours & August 13, 2019 / Phone \\
\hline Phil Craig & $\begin{array}{l}\text { Co-Founder // Lead Historian // } \\
\text { Master Story-Teller }\end{array}$ & Liberation Tours & August 13, 2019 / Phone \\
\hline Jérémie LeBlanc & $\begin{array}{l}\text { Director - Public Relations (2010- } \\
\text { 2017) // Chief Librarian, St. Paul } \\
\text { University }\end{array}$ & $\begin{array}{l}\text { Canadian Battlefields Foundation // St. Paul } \\
\text { University }\end{array}$ & $\begin{array}{l}\text { August 27, 2019 / St. Paul } \\
\text { University, Ottawa / in-person }\end{array}$ \\
\hline David Patterson & President (2009-2013) // Proprietor & $\begin{array}{l}\text { Canadian Battlefields Foundation // Fields of Fire } \\
\text { Tours }\end{array}$ & September 3, 2019 / Phone \\
\hline R.H. Thomson & Artist // Creator & The World Remembers & $\begin{array}{l}\text { September 16, } 2019 \text { / Coffee shop, } \\
\text { Toronto / in-person }\end{array}$ \\
\hline Christina Gaudet & $\begin{array}{l}\text { Senior Program Manager, } \\
\text { Commemoration Division ( } 2014 \text { - } \\
\text { mid 2016, 2018) } \\
\text { Manager of Public Events, Overseas } \\
\text { Commemorative Events } 2017 \text { Task } \\
\text { Force - Overseas Operations Team } \\
\text { (2016-2017) } \\
\text { National Manager, Real Property and } \\
\text { Facilities Management (2019 - } \\
\text { Present) }\end{array}$ & Veterans Affairs Canada (VAC) & January 22, 2020 / Phone \\
\hline
\end{tabular}




\begin{tabular}{|c|c|c|c|}
\hline Robert Löken & $\begin{array}{l}\text { National Manager, Honours, Awards } \\
\text { and Commemoration - } \\
\text { Commemoration Division }\end{array}$ & Veterans Affairs Canada (VAC) & November 20, 2019 / Phone \\
\hline Sylvie Thibodeau-Sealy & $\begin{array}{l}\text { Special Project Officer - Ste. Anne's } \\
\text { Hospital Transfer Project (2010-2015) } \\
\text { Executive Project Officer - Ste. } \\
\text { Anne's Hospital Transfer Project } \\
\text { (2015-2016) } \\
\text { Manager, Policy Coordination and } \\
\text { Issues Management (April 2016 - } \\
\text { December 2016) } \\
\text { Senior Director, Special Projects, } \\
\text { Overseas Commemorative Events } \\
2017 \text { Task Force (December 2016 - } \\
\text { October 2017) } \\
\text { Director, Veterans Priority Programs } \\
\text { Secretariat (October 2017 - July 2018) } \\
\text { Director, Stakeholder Engagement } \\
\text { and Outreach (July 2018 - Present) }\end{array}$ & Veterans Affairs Canada (VAC) & December 10, 2019 / Phone \\
\hline Peter Mills & $\begin{array}{l}\text { Veterans Affairs Canada Liaison } \\
\text { Officer, Canadian Armed Forces and } \\
\text { Department of National Defence (non- } \\
\text { commemoration) (2014 - March } \\
\text { 2016) } \\
\text { Manager - Overseas Events } \\
\text { (Beaumont-Hamel, Battles of the } \\
\text { Somme) (April 2016 - 2017) } \\
\text { Special Advisor to the Director- } \\
\text { General - Overseas Commemorative } \\
\text { Events } 2017 \text { Task Force (Vimy, } \\
\text { Dieppe, Passchendaele) (2017) } \\
\text { National Programme Manager - } \\
\text { Special Initiatives, Commemoration } \\
\text { Operations - Domestic Operations } \\
\text { Team (Canada's 100 Days, Armistice) } \\
\text { (December 2018 - April 2019) }\end{array}$ & Veterans Affairs Canada (VAC) & $\begin{array}{l}\text { November 20, } 2019 \text { / Coffee shop, } \\
\text { Ottawa / in-person }\end{array}$ \\
\hline Ocel Dauphinais-Matheson & $\begin{array}{l}\text { National Historic Site and Visitor } \\
\text { Experience Manager II }\end{array}$ & Parks Canada & $\begin{array}{l}\text { October 18, } 2019 \text { / Vimy Education } \\
\text { Centre, France / in-person }\end{array}$ \\
\hline
\end{tabular}




\section{Ethnography}

Cultural anthropologist, Deborah Reed-Danahay first popularized autoethnography in her 1997 book, Auto/ethnography: rewriting the self and the social (1997) in which she describes the method as "a form of self-narrative that places the self within a social context." ${ }^{, 89}$ However, under the autoethnographic umbrella, there are five forms including "reflexive or narrative autoethnography." 90 This form describes "academics and researchers [who] include themselves as an important aspect of what they are signifying." 91

Autoethnography has gained traction amongst public historians and critical heritage scholars in recent years, especially with those who work in museum studies and at living history sites. As Waterton and Dittmer argue in their piece on affect at the Australian War Memorial (AWM), autoethnography assists in "better capturing situated and embodied performances." 92 They effectively "used [their] bodies as 'instruments of research' in a sensory ethnographic practice backed by participant observation." "93 Tiina Roppola, Jan Packer, David Uzzell, and Roy Ballantyne also employ autoethnography in their analysis on migrant visitors to the Australian War Memorial on ANZAC Day. Their form of autoethnography involved a guerilla interviewing tactic whereby researchers solicited responses to interview questions at the entrances and exits to the AWM. ${ }^{94}$ In both cases, autoethnography worked to identify how assemblages operate in the AWM,

\footnotetext{
${ }^{89}$ Deborah Reed-Danahay, Auto/ethnography: rewriting the self and the social (Oxford: Berg, 1997$), 9$.

${ }^{90}$ David Butz and Kathryn Besio, "Autoethnography," Geography Compass 3, 5 (2009): 1666.

${ }^{91}$ Butz and Besio, “Autoethnography,” 1666.

92 Emma Waterton and Jason Dittmer, "The Museum as Assemblage: bringing forth affect at the Australian War Memorial," Museum management and Curatorship 29, 2 (2014): 127.

${ }^{93}$ Waterton and Dittmer, "“"The Museum as Assemblage," 127.

${ }^{94}$ Roppola, Packer, Uzzell, and Ballantyne, "Nested Assemblages," 1210.
} 
drawing attention to how bodies move through, interact with, and are affected by both human and nonhuman entities.

Through conducting textual analysis using my ATIP archive and interviewing commemorative planners, a commemorative assemblage began to reveal itself. However, during my interviews, conversations often centred on the commemorative landscapes themselves; many of my interviewees mentioned the battlefields, the unique constraints they put on ceremony planning, and where tour operators took participants on battlefield tours. So, in October 2019, after finishing the bulk of my interviews, I travelled to Paris with my partner to conduct field work at the former First World War battlefields included in Canada's centenary commemorations. Based on what I read in the ATIP material and on the advice of interviewees, we visited Beaumont-Hamel, Vimy Ridge, and Passchendaele with quick stopovers at the Menin Gate ceremony in Ypres, Tyne Cot Cemetery, the Canadian memorial in St. Julien, Belgium (the 'Brooding Soldier' as it is colloquially known), Hawthorn Crater on the Somme, the Bourlon Wood Canadian Memorial, and Thiepval Memorial. ${ }^{95}$

We spent two days at Vimy, and a day at Beaumont-Hamel and Passchendaele respectively observing the landscape, talking with tour guides and visitors to the sites, photographing visitor logbooks, and observing how publics moved through the spaces. ${ }^{96}$ It was also important that I experience the spaces myself. I walked the grounds, participated in tours, paused at memorials, and visited the museums. We listened to recommendations provided by my experienced interviewees, ate local pizza in the sleepy

\footnotetext{
95 We had planned to visit many more sites, including Verdun, the Australian War Memorial, Historial de la Grande Guerre at Péronne, and the Canadian Passchendaele Memorial. However, a 48-hour flight delay in Montreal forced us to rearrange our plans.

${ }^{96}$ Macdonald, Memorylands, 9.
} 
former miner's town of Wingles, France, searched for old shell-casings left by farmers on the sides of the roads as we drove through the French and Belgian countryside in our rented Peugeot 108, and took in the breathtaking sight of the glistening white Vimy Memorial as we travelled up and down the French motorways. Conducting ethnographic fieldwork proved vital to this project because, despite my own initial misgivings about the power of things in facilitating affectual experiences, I felt emotional on occasion, especially at Beaumont-Hamel, and finally getting to experience Vimy was like completing my own pilgrimage.

\section{Organization}

This dissertation is organized in two parts. Chapters Two and Three address two major components of commemorative assemblage. Chapter Two uses a combination of ATIP material, interviews, and ethnographic data to reposition the Canadian government's "Big Three" battlefield landscapes, Beaumont-Hamel, Vimy Ridge, and Passchendaele, as affective assemblages and considers the role of nonhuman actors in commemorative practices. To accomplish this, the chapter provides an historical background on each landscape, paying careful attention to the subliminal messaging of these places and spaces. Chapter Three employs ATIP documentation, supplemented by information gleaned in interviews, to provide an in-depth analysis of the centenary from a labour perspective. In exploring commemorative planning as work, this chapter also sheds light on the backstage office work and workers and considers the quotidian as difficult yet necessary work in the realizing of large-scale federal commemorative events. 
The subsequent two chapters unpack the affective dimensions of the assemblages discussed in Chapters Two and Three. Chapter Four uses media, ATIP information, and interview comments to explore how metanarrative affected embodied experience during and after the centenary events. It considers, for example, the relative unimportance of historical metanarratives when lavatory facilities malfunction. Finally, Chapter Five relies almost exclusively on interviews to understand the emotional aspects of commemorative labour as byproducts of the unpredictable, fluid assemblages I identified in Chapters Two and Three. The chapter argues that workers were deeply affected by the challenges of interacting with multiple commemorative assemblages. An examination of the emotions of commemorative workers highlights challenging working conditions that placed unnecessary stress on workers which led to fatigue and eventually, burnout.

In acknowledgement that commemorations involve nation-building, identity formation, and a preservation of collective/collected/multidirectional memory, this dissertation uses an archive comprised of policy and planning documents, the stories of commemorative planners and stakeholders, media, and my own ethnographic observations to offer new perspectives on what commemorations are, who plans them, and how they work. Using the centenary of the First World War as a case study, I argue that commemorations such as those considered here are not static or passive, not planned by a monolithic government, and are not even inherently national as they involve a great deal of international cooperation. And though the following chapters exhibit an assembly of landscapes, things, ideas, and people, it is important to remember that the relational assemblages I uncovered are unique to my own inquiry because, as I assert in the following pages, looking at commemoration through the lens of assemblage means 
understanding that they are in a constant state of flux. Indeed, as I write this, the assemblages I identified here may already be different. 


\section{Chapter Two: Assembling Commemorative Landscapes}

The monuments are like Pokémon cards: you gotta collect all the Canadian official monuments if you can. They all look the same. The monuments themselves are not the destination so to speak. It's the story told there.

- David Patterson, Fields of Fire Tours ${ }^{1}$

\section{Introduction}

David Patterson's observations of the First World War monuments along the Western Front hints at the ways the intangible and tangible are interconnected in all commemorative landscapes. But his comments also allude to the journeys that we take to, at, and away from these sites in pursuit of an experience. This chapter wrestles with all these ideas as they relate to Veterans Affairs Canada's (henceforth VAC's) "Big Three" European commemorative landscapes: Beaumont-Hamel Newfoundland Memorial; National Vimy Ridge Memorial; and Passchendaele (via the Memorial Museum Passchendaele 1917). It does so by framing these sites, their surroundings, and the various travel routes that connect them as part of a greater assemblage and asks: what might we learn if we conceptualize commemorative landscapes as powerful and affectual entities (or assemblages) that nest and/or are in concert with other assemblages at indeterminate moments? And what if - as the assemblage scholars of the previous chapter suggest - these landscape assemblages are powerful enough to affect humans both on site and from afar?

Patterson's comments frame the battlefield commemorative landscapes as rather inert stages upon which people make their experiences, collecting the monuments and seeking out the stories that they represent. His perspective is not unique and reflects a

\footnotetext{
${ }^{1}$ David Patterson, Interview by Breanna Lester, September 3, 2019.
} 
body of scholarly commemoration literature that also accentuates the passivity of landscapes and the activity of human actors. For example, John Urry's core argument in The Tourist Gaze $(1990,2002,2011)$ is predicated on the idea that humans gaze upon tourist sites (often landscapes). "We look at the environment with interest and curiosity. It speaks to us in ways we appreciate," Urry writes. Belying this sense of landscapes that "speak," however, Urry later states that "There are in fact many professional experts who help to construct and develop our gaze as tourists." ${ }^{2}$ So, while it seems Urry recognizes agency within tourist landscapes, he ultimately emphasizes humans as sole actors in the gazing process who learn from other humans how to see and know these spaces.

Commemoration scholars, especially those who draw on Urry's paradigmatic work, frame landscapes in similar ways. For example, Martin J. Murray's Commemorating and Forgetting (2013) refers to landscapes as "repositories of shared memories." ${ }^{\prime 3}$ In his story, South African commemorative landscapes are manipulated to assist in the forging of an identity suitable to the new 'democratic' regime. ${ }^{4}$ Though he does draw attention to the ways the District 6 Museum, for example, acts as a "living memorial" that is "not silent," his focus remains on how humans craft commemorative spaces to suit political agendas. ${ }^{5}$ In a study of the emergence of living history in Canada, Alan Gordon's Time Travel (2016) describes these sites as "reshaped," "landscaped," "restored," and "repurposed." Once again, human actors are at the centre of his study,

${ }^{2}$ John Urry, The Tourist Gaze (London: Sage Publications, 2002), 1; John Urry, The Tourist Gaze: Leisure and Travel in Contemporary Societies (London: Sage Publications, 1990); John Urry and Jonas Larsen, The Tourist Gaze 3.0 (London: Sage Publications Inc., 2011).

${ }^{3}$ Martin J. Murray, Commemorating and Forgetting: Challenges for the New South Africa (Minneapolis: University of Minnesota Press, 2013), 15.

${ }^{4}$ Murray, Commemorating and Forgetting, viii.

${ }^{5}$ Murray, Commemorating and Forgetting, 125.

${ }^{6}$ Alan Gordon, Time Travel: Tourism and the Rise of the Living History Museum in Mid-Twentieth Century Canada (Vancouver and Toronto: UBC Press, 2016), 15, 46, 63, 72. 
and in an investigation into Canada's living history museums as "entrenched in Canada's tourist landscape," the landscapes themselves appear as largely passive stages for historical and commemorative experiences. ${ }^{7}$

As a known and respected landscapes scholar, Brian S. Osborne begins a chapter in a collection of essays titled, Place, Culture and Identity: Essays in Historical Geography in Honour of Alan R. H. Baker with a quote by historian Simon Schama: "National identity, to take just the most obvious example, would lose much of its ferocious enchantment without the mystique of a particular landscape tradition: its topography mapped, elaborated, and enriched as a homeland."8 Though Schama's quote is another prominent example of culture working on rather than with landscapes, Osborne does recognise landscapes as assemblages of sorts. In "Landscapes, memory, monuments, and commemoration," Osborne details a history of assemblage scholars and ultimately describes them as "storied." However, it is difficult to determine from his text how he understands landscapes as powerful assemblages which operate as active historical agents because of his continued emphasis on landscapes as "depositar[ies] of symbolic space and time." 10 For his part, Schama's use of the past tense in his description of how landscapes become "homeland" suggests that these landscapes are inert, acted upon, and scripted by humans. Thus, while both Schama's and Osborne's works gesture to

\footnotetext{
${ }^{7}$ Gordon, Time Travel, 16.

${ }^{8}$ Simon Schama, Landscapes and Memory (Toronto: Vintage Canada, 1995), 15, quoted in Brian S. Osborne, "Warscapes, Landscapes, Inscapes: France, War, and Canadian National Identity," in Place, Culture and Identity: Essays in Historical Geography in Honour of Alan R. H. Baker eds. Iain S. Black and Robin A. Butlin Les Presses de l'Universite Laval, 2001, 311.

${ }^{9}$ Brian S. Osborne, "Landscapes, Memory, Monuments, and Commemoration: Putting Identity in its Place," Canadian Ethnic Studies 33, 3 (2001): 49.

10 Osborne, "Landscapes, Memory, Monuments, and Commemoration," 50.
} 
interrogating landscapes as nested assemblages always in a state of becoming, and thus unstable across time, neither really follows through on this promise.

Paul Gough's "Sites in the imagination" (2004) is an example of scholarship that lends itself to a more open conversation of the affective potential of landscapes. His article draws attention to the "spatiality" of public monuments and cautions readers not to look at them as "innocent aesthetic embellishments of the public sphere." ${ }^{11}$ However, his article is centrally focused on how, in the process of shaping the Beaumont-Hamel landscape, preservationists effectively created a "landscape of allusion" meant to alter and focus the memory of that landscape solely on the Battle of Beaumont-Hamel. ${ }^{12}$ Though Gough's work provides a more nuanced perspective on the spatiality of landscapes, his article is less interested in exploring the idea that the landscape of Beaumont-Hamel co-produces memory with human actors (preservationists and tourists).

Though he does not discuss the theoretical idea of assemblage explicitly, Kirk Savage's Monument Wars (2009) describes Washington D.C.'s commemorative landscapes in vibrant, animated language and also portrays them as unfinished and consistently in flux. As he advocates for the importance of histories of memorial landscapes, Savage writes that as "[memorial landscapes] take shape on the ground, they become enmeshed in the complex realities of a living America." He goes on to argue that memorial landscapes "[come] alive" and "[become] [...] actor[s]."13 In the book's conclusion, he imagines a "living landscape, diverse and open to change." ${ }^{14}$ While he

\footnotetext{
${ }^{11}$ Paul Gough, "Sites in the imagination: The Beaumont-Hamel Newfoundland Memorial on the Somme," Cultural Geographies 11 (2004): 239.

${ }^{12}$ Gough, "Sites in the imagination," 251.

${ }^{13}$ Kirk Savage, Monument Wars: Washington, D.C., the National Mall, and the Transformation of the Memorial Landscape (Berkeley: University of California Press, 2005), 11.

${ }^{14}$ Savage, Monument Wars, 312.
} 
does not explicitly call them assemblages, Savage's commemorative landscapes are anything but passive; rather they read as ever-changing, affective agents.

As coveted and prominent commemorative landscapes in the settler-colonial nationalist imagining of Canada, Beaumont-Hamel, Vimy, and Passchendaele are powerful assemblages, and their memorial landscapes reflect this: Beaumont-Hamel represents a national struggle with a colonial past; Vimy Ridge is Canada's commemorative crowned jewel and coveted national birthplace; Passchendaele is the site of Canada's "baptism of fire." ${ }^{15}$ In its pursuit of a repackaging of landscapes as assemblages, this chapter does not further belabour the history of the battles that took place on what are now commemorative sites. Rather, in the first section of this chapter I provide an historical overview of each as they transitioned from battlefields to sacred commemorative landscapes. For the second part, I consider tourist reviews, commentary by battlefield tour operators, and subsequently use an ethnographic approach to explore how these sites affect and are affected by their visitors. This approach encourages both spatial and embodied perspectives on how these geographies and their amenities operate. Following my ethnographic examination of each site, this chapter focuses exclusively on some of the ways the assemblages affect humans through perspectives of "being on the ground" and from afar such as through material exchange, and specifically, the patriation of soil. Together, these perspectives assist in reimagining these commemorative landscapes less as passive things to be acted and commemorated upon, but rather as powerful entities to act and commemorate with.

${ }^{15}$ Tim Cook, Vimy: The Battle and the Legend (Toronto: Penguin Random House, 2017), 186. 


\section{Assembling "The Big Three" - 1918 - Present}

As Manuel DeLanda states in his 2016 book, Assemblage Theory, "[a]ssemblage theory views the world as configured through ongoing relations between assemblages at different scales and through historical processes." 16 Accordingly, to understand how commemorative landscape assemblages functioned during the centenary, it is important to examine their histories as commemorative sites-in-formation. The transition of Beaumont-Hamel, Vimy, and Passchendaele to commemorative landscapes occurred quickly after the Armistice. According to tourism scholar David W. Lloyd, "landscapes of the battlefields changed as people in Northern France and Belgium returned to and rebuilt their homes." ${ }^{17}$ While locals sought to return to their everyday lives, though, those from away made other claims on the battlefields specifically. A number of federal governments facilitated the intervention immediately after Armistice by battlefield restoration organizations such as the Commonwealth War Graves Commission (CWGC), and in very short order these warscapes became sacred commemorative landscapes. ${ }^{18}$

According to Paul Gough, the Newfoundland government pushed to purchase the site of the Battle of Beaumont-Hamel soon after Armistice as one of five battlefields they wished to landscape into memorial sites for the Dominion. After negotiations with approximately 250 neighbouring French landowners, Newfoundland's government finalized purchase of the 16.5-hectare site in July $1921 .{ }^{19}$ When it was first acquired, the

\footnotetext{
${ }^{16}$ Manuel DeLanda, Assemblage Theory (Edinburgh: Edinburgh University Press, 2016), 3.

${ }^{17}$ David W. Lloyd, Battlefield Tourism: Pilgrimage and the Commemoration of the Great War in Britain, Australia and Canada, 1919-1939 (London: Bloomsbury, 1998), 76.

${ }^{18}$ I adopt the language of "warscapes" from Brian Osborne, "“Warscapes, Landscapes, Inscapes: France, War, and Canadian National Identity," in Iain Black and Robin Butlin, eds., Place, Culture, and Identity

(Laval: Laval University Press, 2001), 311-333.

${ }^{19}$ Gough, "Sites in the imagination," 242.
} 
landscape was scarred and barren, and the valleys left by ordinance and remnants of the abandoned tunnels and trenches remained. Once unexploded ordinance was cleared from the site, construction began on its restoration in 1922. The architect, Dutch-born and Newfoundland resident Rudolph Hogo Karel Cochius, wished to establish a monument and ascribe meaning to its surrounding landscape. Consequently, a large bronze caribou was erected atop a pedestal positioned towards the advancing German enemy of July 1 , 1916 and overlooked what he envisioned as a visual representation of the battle including a preserved trench system and cemeteries. ${ }^{20}$ As Gough mentions, the designer strategically placed tree lines to guide visitors to nearby sites including Hawthorn Crater (the site of a mine explosion near where the Newfoundlanders were to begin their attack on the morning of July 1, 1916), and along the northern perimeter of the site leading visitors to the Highland Division Memorial and cemeteries. ${ }^{21}$ During its initial restoration, shrubbery consisting of species native to Newfoundland, such as white spruce, dogberry, juniper, and birch, in addition to 35000 imported trees from Newfoundland were chosen for the landscape. ${ }^{22}$ Once the initial alterations were complete, the site was opened by Sir Douglas Haig in July 1925 and remained under the jurisdiction of Newfoundland until it joined Confederation in 1949, at which time the Beaumont-Hamel Park came under the jurisdiction of the Government of Canada. In 1961, then Premier of Newfoundland Joseph Smallwood dedicated a bronze plaque to the battle honours of the Royal Newfoundland Regiment (RNR). ${ }^{23}$ The site

\footnotetext{
${ }^{20}$ A caribou was chosen for the monument as it is the symbol of the Royal Newfoundland Regiment. Gough, "Sites in the imagination," 242.

${ }^{21}$ Ibid.

${ }^{22}$ Gough, "Sites in the imagination," 243.

${ }^{23}$ Gough, "Sites in the imagination," 247.
} 
underwent further refurbishments in the 1960s when some of the overgrown shrubs on the monument were replaced by smaller species, and the visitor's centre was built. Once the restorations were complete, the Beaumont-Hamel landscape came to tell a very specific story, one that did not include the Germans or the Scots who fought on the same battleground five months after July 1, 1916. ${ }^{24}$ In Gough's words, "the site has been topographically rearranged so as to focus on a thirty-minute action during a fifty-month war." ${ }^{25}$ Nonetheless, by the 1960 s, Beaumont-Hamel belonged to the Canadian government and, as a result, in 1997, the Beaumont-Hamel Newfoundland Memorial joined the National Vimy Ridge Memorial as one of the only two Canadian National Historic Sites outside of Canada. ${ }^{26}$

VAC considered plans to further restore Beaumont-Hamel and Vimy in 2000 as millions of tourists continued to flock to the sites. Their research calculated that approximately one million tourists visited Vimy, and 250000 people toured BeaumontHamel annually and, as a result, the landscapes were beginning to experience wear-andtear. Subsequently, VAC organized a symposium which gathered battlefield conservationists, architects, historians, and consultants to discuss possible solutions. The outcome of this meeting was a piece of legislation, the Vimy Declaration for the Conservation of Battlefield Terrain (known also as the Vimy Charter) which essentially aimed to control where visitors could walk and accordingly installed footpaths and railings to ensure obedience. ${ }^{27}$ It was also as a result of this symposium that the original

\footnotetext{
${ }^{24}$ Paul Gough, "CContested memories: contested site': Newfoundland and its unique heritage on the Western Front," The Round Table 96, 393 (2007): 698.

${ }^{25}$ Gough, "Sites of the Imagination," 252.

${ }^{26}$ Gough, "Sites in the imagination," 247.

${ }^{27}$ Gough, "Contested memories: contested site," 697.
} 
name of the Beaumont-Hamel landscape, the Newfoundland Memorial Park, was changed to the Beaumont-Hamel Newfoundland Memorial. This, according to Gough, "ensure[d] that the former battlefield was regarded as a 'reverential' space as distinct from a place of recreation or historical re-enactment."${ }^{28}$

In addition to the alternations made to the National Vimy Ridge Memorial by the Vimy Charter, there are several other restorative moments that have shaped the site tourists visit today. After determining that Canada should erect monuments to mark their war experience in Europe, Prime Minister Borden formed a special committee in April 1920. In consultation with decorated General Arthur Currie, the committee determined eight possible memorial sites, chief of which was Vimy because of its prominent geographical location and label as Canada's "first large-scale victory on the Western Front." ${ }^{29}$ Though Currie and many other veterans objected to the idea that Vimy should represent the Canadian experience, after the design competition for all eight coveted sites closed, and sculptor Water Allward won with his grandiose model based solely on the Vimy memorial space, the traction for eight memorial sites waned. As a result, in 1921, Vimy became the memorial vocal point ${ }^{30}$ Despite the continued resistance to the idea by veterans who wished to see Hill 62 (Sanctuary Wood) as Canada's prominent site, in 1922, Allward signed a five-year contract to erect a monument at Vimy Ridge. However,

\footnotetext{
28 Ibid.

${ }^{29}$ Cook, Vimy, 180.

${ }^{30}$ Cook, Vimy, 183-184. According to Ian McKay and Jamie Swift in The Vimy Trap, First World War veterans did not initially approve of the decision to select Vimy as the foremost Canadian commemorative site because many did not view Vimy as the most "decisive" battle of the war. Many veterans actually preferred Hill 62 at Ypres. Nevertheless, it was Vimy's picturesque location that won in the end. Ian McKay and Jamie Swift, The Vimy Trap: Or How We Learned to Stop Worrying and Love the Great War (Toronto: Between the Lines, 2016), 150.
} 
Allward hit several setbacks after 1922 including his own perfectionism, tiffs with prime ministers, and financial troubles which delayed the unveiling by several years. ${ }^{31}$

The monument itself was an artistic masterpiece; from its conception, the sculpture was to give the impression of a "bastion" with protruding spires draped with allegorical figures meant to represent "loss and sorrow." 32 The design also allowed for sunlight to beam down between the spires and reflect on the sculptures, creating a cathedral effect. ${ }^{33}$ Allward was adamant from the beginning that he did not wish to sculpt a monument to victory; he was haunted by the ghosts of Vimy Ridge and attempted to express this through his creation. ${ }^{34}$

The location of the site in France and the scarred state of the former battlefield in the early 1920s posed even more challenges for Allward and his vision. In 1923, headed by the recently established Canadian Battlefields Memorial Committee (CBMC), the clearing and excavation of the site began. In 1924, the CBMC and the French Department of Agriculture commissioned the planting of thousands of Austrian pines in efforts to reforest the war-torn landscape. ${ }^{35}$ Concurrently, the land in front of the monument was depressed to create an illusion that the monument was part of the surrounding landscape, and the trenches and tunnels were preserved. ${ }^{36}$ This indented area around the front of the monument would become a large grassy amphitheatre with the intention of hosting ceremonies. After many anticipatory years, a pilgrimage was organized involving 7500

\footnotetext{
${ }^{31}$ For an in-depth chronicle of Allward's plights during construction of the Vimy Memorial, see Tim Cook, Vimy, 191-217.

${ }^{32}$ Cook, Vimy, 183.

${ }^{33}$ Jacqueline Hucker, "Battle and Burial: Recapturing the Cultural Meaning of Canada's National Memorial on Vimy Ridge," The Public Historian 31, 1 (2009): 98.

${ }^{34}$ Cook, Vimy, 191; for an in-depth look at Allward's monument and its meaning, see Tim Cook, Vimy, 191-217.

${ }^{35}$ Hucker, "Battle and Burial," 102.

${ }^{36}$ Hucker, "Battle and Burial," 103.
} 
attendees from both Canada and Britain to conclude at the new memorial and memorial park on July 26, 1936 for its unveiling. ${ }^{37}$ After 1936, the monument and park remained largely unaltered until 1997 when the first Vimy interpretation centre was installed shortly after Vimy and Beaumont-Hamel were dedicated as National Historic Sites. In September 2001, as a result of the Vimy Charter, VAC proposed a massive reconstruction and restoration project. The Canadian Battlefield Memorial Restoration Project (CBMRP) cost $\$ 30$ million and involved the restoration of the Vimy monument, battlefield terrain conservation at Vimy and Beaumont-Hamel, and "subterranean features investigation" at both sites. ${ }^{38}$ In total, this project took six years to finish, and upon completion the Vimy Memorial was re-dedicated by Queen Elizabeth II on April 9, 2007 on the ninetieth anniversary of the Battle. ${ }^{39}$

In 2013, the Government of Canada announced their partnership with the Vimy Foundation to erect a new education centre at Vimy Ridge to replace the former interpretation centre. In all, the new centre cost $\$ 10$ million ( $\$ 5$ million raised by the Foundation, and $\$ 5$ million by the government). ${ }^{40}$ According to VAC, its purpose is to "help visitors better understand the powerful elements they would encounter while still allowing them to remain firmly connected with the memorial and surrounding

\footnotetext{
${ }^{37}$ Cook, Vimy, 261.

38 Though the language of the audit report is vague, I interpret "subterranean features" to include human remains, shells, and other ammunitions. Veterans Affairs Canada, "Repair, Restoration and Rehabilitation of Canada's First World War Memorials in Europe - Audit Report,” February 2004, https://www.veterans.gc.ca/public/pages/department/reports/cbmrp_feb2004e.pdf.

39 Tara Gesner, "Vimy memorial restoration took years to complete," Carleton Place Almonte Canadian Gazette, April 7, 2017, https:/www.insideottawavalley.com/news-story/7231739-vimy-memorialrestoration-took-years-to-complete/.

${ }^{40}$ ATIP, Christina Gaudet, email to Lynn MacDonald, May 8, 2013.
} 
landscape. ${ }^{41}$ This was accomplished through the use of windows that would ensure visitors could see the craters and trenches from the inside and also view their permanent exhibit, We Will Remember, from the outside. The exhibit chronicles the Canadian Expeditionary Force (CEF) and RNR's journeys through the First World War and provides a context for the Battle of Vimy Ridge and the monument that commemorates it. The centre ostensibly incorporates many of the elements that make up the Vimy assemblage, from the trenches and craters, to the monument, to the adjacent car park. Interpreting it in this way reframes the purpose of the centre as a central unifying entity. ${ }^{42}$

On November 5, 2018, the Vimy Foundation issued a press release announcing the opening of its new Centennial Park on November 9, 2018, two days before the Armistice centenary. The releases described the Park as a "modern living memorial," that allows visitors to "walk its paths of remembrance" and is meant as a place of contemplation, education, and community. Accordingly, it was said to act as an "opportunity for gathering, dialogue, and extended reflection, all essential elements to conflict resolution and peace that the monument inspires." Purchased from a local farmer, the four-acre plot had to be de-mined before construction of the Park commenced. In doing so, "many artifacts were discovered including shells (some of which were still active), grenades, fuses, and communications wires, as well as the remains of soldiers who fought at Vimy Ridge over 100 years ago and who have now been put to rest in an official military graveyard." Highlights of the Park include the repatriation of the Vimy

\footnotetext{
${ }^{41}$ Veterans Affairs Canada, “A window on Canada's First World War,” Government of Canada, https:/www.veterans.gc.ca/eng/remembrance/memorials/overseas/first-world-war/france/vimy/educationcentre/design-on-windows.

${ }^{42}$ The gallery of construction photographs for the visitor's centre can be viewed here: https:/www.veterans.gc.ca/eng/remembrance/memorials/overseas/first-world-war/france/vimy/educationcentre/building-a-legacy/from-the-ground-up
} 
Oaks (trees that were allegedly picked on the Vimy battlefield by a Canadian soldier in 1917, grown in Canada, and now re-planted in France), and a Bugler memorial gifted to the Vimy Park by the City of Barrie, Ontario. Stakeholders for this project include the Province of British Columbia, Molson Coors, and CFB Borden. ${ }^{43}$

Passchendaele is part of a greater area called the Ypres Salient which covers 24 square kilometers and witnessed several battles between 1914 and $1918 .{ }^{44}$ By 1920, 200 cemeteries were constructed across the Salient to inter the dead of all involved including the British Commonwealth (100 cemeteries), Germany (one cemetery), France (two cemeteries), and Belgium (one cemetery) ${ }^{45}$ In 1919, Sir Arthur Currie and Brigadier Henry Thorsby Hughes chose eight memorial sites: Vimy Ridge, Bourlon Wood, Le Quesnel, Dury, and Courcelette in France, and St. Julien, Hill 62 (Sanctuary Wood), and Passchendaele in Belgium to be adorned with similar markers. ${ }^{46}$

\footnotetext{
${ }^{43}$ The Vimy Foundation, “The Vimy Foundation Centennial Park,” The Vimy Foundation, https://www.vimyfoundation.ca/the-vimy-foundation-centennial-park/.

${ }^{44}$ The Great War 1914-1918, "Battles of the Ypres Salient," 2009, http://www.greatwar.co.uk/ypres$\underline{\text { salient/battles-ypres- }}$ salient.htm\#: :text=The $\% 20$ Allied $\% 20$ determination $\% 20$ to $\% 20$ protect,of $\% 20$ some $\% 2024 \% 20$ square $\% 20$ kilometres.

${ }^{45}$ Tonie and Valmai Holt, Major \& Mrs. Holt's Battlefield Guide to Ypres Salient \& Passchendaele (Barnsley: Pen \& Sword Military, 2011), 27; Cemeteries and Locations on the WW1 Ypres Salient Battlefields, Belgium (greatwar.co.uk).

${ }^{46}$ Cook, Vimy, 179.
} 
As Allward's Vimy memorial design derailed the plan to erect similar memorials across all eight significant Canadian sites, the selection committee prepared to choose a secondary design for the remaining seven. However, Frederick Clemesha's "Brooding Soldier" (Figure 2.1) - one of the seventeen finalists chosen in 1921 as potential memorials for Canada's commemorative sites - was too unique to be replicated six additional times. Subsequently, the "Brooding Soldier" was erected at St. Julien, and the remaining six locations (including the Canadian Passchendaele Memorial) each received a fourteen-tonne block carved from Canadian granite installed in $1922 .{ }^{47}$

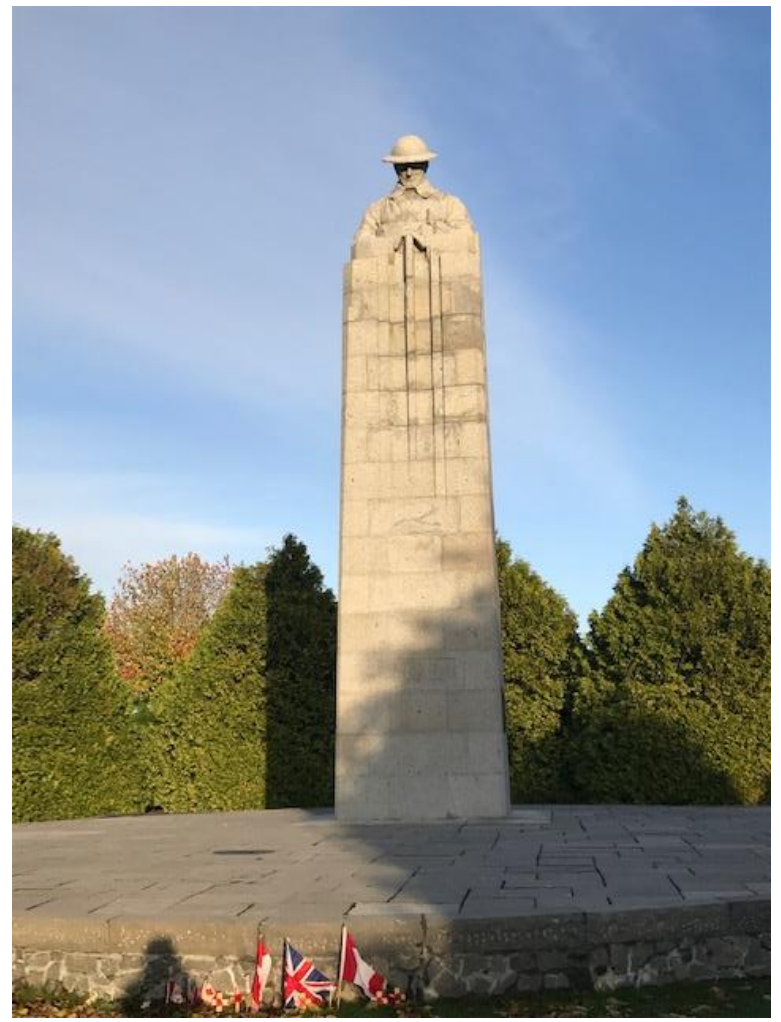

Figure 2.1 - Image of the "Brooding Soldier" monument at St. Julien, Belgium. Photograph taken by Breanna Lester in October 2019.

${ }^{47}$ Cook, Vimy, 195-197. 


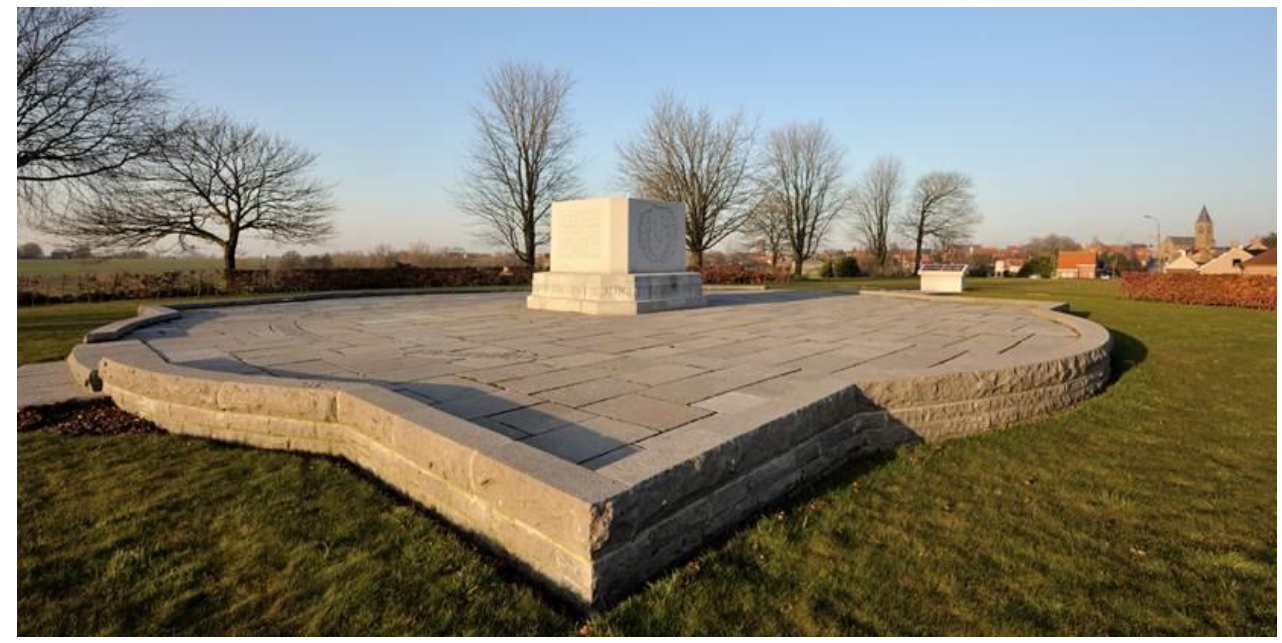

Figure 2.2 - Image of Canadian Passchendaele Memorial at Crest Farm. Image courtesy of VisitFlanders: https://www.visitflanders.com/en/things-to-do/events/top/great-warcentenary/passchendaele-ceremony-canadian-ceremony-of-remembrance.jsp

It was made clear in its design that the "Brooding Soldier" was as significant a monument as the National Vimy Memorial. The park around the monument was created using soil, conifer trees, and juniper shrubs brought from Canada. ${ }^{48}$ However, there is little evidence to suggest the "Brooding Soldier", or Canadian Passchendaele Memorial (Figure 2.2) received as much restorative attention as the Beaumont-Hamel and Vimy sites in the years after they were installed in the early 1920s. According to David Lloyd in Battlefield Tourism, tourists were encouraged to visit the Ypres Salient through the 1920s, aided by British organizations such as the Ypres League established for this very purpose. There was even a small ceremony performed in Ypres ahead of the large 1936

\footnotetext{
${ }^{48}$ Government of Canada, "Canadian Route of Remembrance in Belgium 1915-1917: the Ypres Salient," January 26, 2018, https://www.canadainternational.gc.ca/belgiumbelgique/bilateral_relations_bilaterales/route1915-17.aspx?lang=eng.
} 
pilgrimage to Vimy Ridge, and Canadian pilgrims were encouraged to visit the Passchendaele memorial before attending the unveiling at Vimy. ${ }^{49}$

However, the "Brooding Soldier" and Canadian Passchendaele Memorial did receive restorative attention as part of the 2001 CBMRP. According to minutes from a 2002 parliamentary meeting of the Sub-Committee on Veterans Affairs, the project also focused attention on St. Julien and Passchendaele as two of the other eleven memorials (aside from Beaumont-Hamel and Vimy) and planned to "focus on repairs to walkways and platforms, repointing of retaining walls, and basic horticultural work." 50

Despite informational plaques at these sites, they lacked a central location to educate publics on the Canadian First World War experience like the visitor's centres at Beaumont-Hamel and Vimy. So, as part of the centenary planning, VAC proposed spending \$300 000 over three years on “enhancements” to the Memorial Museum Passchendaele 1917 (see Figure 2.3), a centrally-located museum that was already established as a nexus for sharing the Great War experiences of Germany, Belgium, France, and the British Commonwealth (including Australia and New Zealand). ${ }^{51}$ These planned enhancements included adding a film, centennial brochure, a Canada-specific exhibit, a poppy garden, and three hiking trails intended to enhance the commemorative experience of visitors to the museum.

${ }^{49}$ Lloyd, Battlefield Tourism, 122.

$5037^{\text {th }}$ Parliament, ${ }^{\text {st }}$ Session: Sub-Committee on Veterans Affairs of the Standing Committee on National Defence and Veterans Affairs. March 21, 2002, https://www.ourcommons.ca/DocumentViewer/en/371/SVET/meeting-6/evidence.

${ }^{51}$ ATIP, John Desrosiers, email to Julie Maceachern, September 7, 2016. 


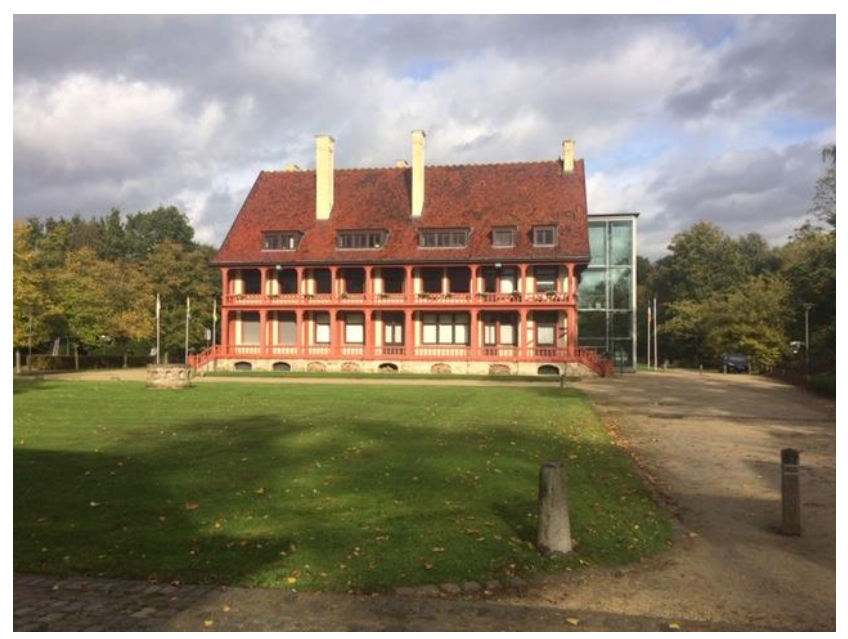

Figure 2.3 - Photograph of the Memorial Museum Passchendaele 1917. Photograph taken by Breanna Lester in October 2019.

The histories of these commemorative sites reveal a spatiality and materiality that was present from their very conception; at each of the three locations, there were concerted efforts to combine constructed and "natural" elements that would collectively narrate the events that attributed importance to these landscapes. Beaumont-Hamel stands as a combination of native trees and shrubs, built monuments, cemeteries, pathways, and reconstructed trenches. Vimy is Allward's monument, but it is also the trenches and craters, visitor's centre, and Centennial Park. And finally, though Ypres (Passchendaele) is less enclosed than the other sites, the "Brooding Soldier," stone slab monuments, and, recently, the Memorial Museum Passchendaele 1917, amalgamate to narrate the Canadian experience at Ypres during the war. However, as the above histories also show, there has been a great deal of human intervention in the assembling of these sites; governments, architects, conservationists, and visitors have also impacted how these landscapes look and the stories they tell. 


\section{Tourist Responses}

The landscapes at the core of this chapter are both tourist destinations and emotional spaces of pilgrimage. As discussed earlier, people began to interact with the former battlefields soon after Armistice. These encounters were often deeply emotional and personal. Tourism scholar David Lloyd discusses some of these early experiences as mournful, and a way for relatives of the dead to feel close to their deceased loved ones. ${ }^{52}$ However, as Lloyd also explains, there was a discrepancy between these landscapes as developing sacred spaces, and the needs of the French and Belgian governments to commercialise these areas to aid in their rebuilding efforts which resulted in these sites becoming both places of tourism and pilgrimage. ${ }^{53}$ Some scholars, like Lloyd, draw distinction between tourism and pilgrimage; he suggests it is the relationship between the sacred and profane that sets a tourist apart from a pilgrim. ${ }^{54}$ However, other scholars appreciate the complexity of these two terms. To tourism scholar Marita Sturken, tourism is a detached and "innocent" experience that often involves the consumption of aspects of the chosen destination, but a tourist can also be a pilgrim if, "they feel that they have experienced a connection to [the] traumatic events and have gained a trace of authenticity by extension." ${ }^{, 55}$ Furthermore, Jennifer Iles signals a blurring of tourist and pilgrim because, as she argues, neither category is isolated from the other. ${ }^{56}$ Indeed, as Iles also suggests, visitors to commemorative sites do not choose to visit them to merely sightsee;

\footnotetext{
${ }^{52}$ Lloyd, Battlefield Tourism, 17.

${ }^{53}$ Lloyd, Battlefield Tourism, 40.

${ }^{54}$ Lloyd, Battlefield Tourism, 18.

${ }_{55}$ Marita Sturken, Tourists of History: Memory, Kitsch, and Consumerism from Oklahoma City to Ground Zero (Durham: Durham University Press, 2007), 9-11.

${ }^{56}$ Jennifer Iles, "Recalling the Ghosts of War: Performing Tourism on the Battlefields of the Western Front," Text and Performance Quarterly 26, 2 (2006): 171.
} 
they want to "identify and empathize with its symbolic, commemorative spaces." $" 57$ In this sense, visitors to sites of war commemoration can participate in both tourism and pilgrimage, or as Jan Margry and others call it, secular pilgrimage. ${ }^{58}$

Examining the centenary commemoration sites through the lens of secular pilgrimage positions them as affective environments. Thus, to better appreciate the emotional power of these sites, I had to understand how visitors interacted with and discussed them. As a platform, TripAdvisor aims to provide resources and material to "help travellers around the world unleash the full potential of every trip" through the provision of a platform for reviews, shopping tools, and accommodation booking. ${ }^{59}$ Consequently, most every tourist destination has a TripAdvisor page, including former Great War battlefield sites such as those considered in this chapter. ${ }^{60}$ With acknowledgement that people who post on TripAdvisor are motivated from within to do so, I interpreted the quantitative content of the reviews as suggestive of larger trends, and analyzed the qualitative contents discursively, as I was interested in how visitors expressed enthusiasm or frustration after their experiences.

The Beaumont-Hamel Newfoundland Memorial has 433 reviews on TripAdvisor, averaging a rating of five stars, with many reviews in the "excellent" column (89\%). ${ }^{61}$

\footnotetext{
${ }^{57}$ This analysis also adds nuance to Urry's Tourist Gaze given that when tourists visit sites, they not only see, but also feel: Iles, "Recalling the Ghosts of War," 165.

${ }^{58}$ Jan Margry, ed., Shrines and Pilgrimage in the Modern World: New Itineraries into the Sacred (Amsterdam: Amsterdam University Press), 13.

59 Trip Advisor, "2017 Annual Report and Notice of 2018 Annual Meeting and Proxy Statement," http://ir.tripadvisor.com/static-files/840c6d1c-9c17-46c9-b52f-3586ead2515f.

${ }^{60}$ The form of battlefield tourism I discuss in this chapter is labelled by tourism scholars as "thanatourism" or "dark tourism." For a greater discussion of this concept, see John J. Lennon and Malcom Foley, Dark Tourism: The Attraction of Death and Destruction (London: Thomson, 2006); Tony Seaton, "Encountering Engineered and Orchestrated Remembrance: A Situational Model of Dark Tourism and Its History," in The Palgrave Handbook of Dark Tourism Studies eds. Philip R. Stone, Rudi Hartmann, Tony Seaton, Richard Sharpley, and Leanne White, Palgrave Macmillan, 2018.

${ }^{61}$ This data is based on research conducted in 2019.
} 
Most reviews appear in English (404 in total), with sixty-nine in French, and the rest in various other languages. The top reviews, most of which come from British visitors, call the experience "sobering," the space "atmospheric" and "emotional." The only "average" rating I found was from a British visitor who commented on the "manicured look" of Beaumont-Hamel and communicated their disappointment in how much the site had changed since their last visit seven years prior. In this particular visitor's opinion, manicuring battlefields "detracts from the terrible events that occurred 100 years ago."62 In a "very good" review, another visitor made passing reference to their disappointment regarding the lack of food available on site.

The page dedicated to the "Canadian National Vimy Memorial" has 1301 reviews, $86 \%$ of them excellent, with an average rating of five stars. ${ }^{63}$ An overwhelming majority of the reviews are in English (933 of 1301), 319 in French, and others in Dutch (thirty-five), Italian (four), Portuguese (three), Russian (two), and Spanish (two). ${ }^{64}$ Many of the "excellent" reviews discuss the monument's beauty, and the friendliness and knowledge of the staff. Discussions of sacrifice for national freedoms are also prominent, in addition to several recommendations specifically for Canadians to visit the site. One visitor from Toronto, reflecting on an April 2019 visit to the site remarks: "As I arrived and saw the Canadian Flag flying in a soft breeze, I knew this was going to be a very

\footnotetext{
62 Trip Advisor, "Beaumont-Hamel Newfoundland Memorial," https://www.tripadvisor.ca/Attraction_Review-g2436295-d2428688-ReviewsBeaumont_Hamel_Newfoundland_Memorial-Beaumont_Hamel_Somme_Hauts_de_France.html. ${ }^{63}$ Statistics gathered on July 4, 2019. https://www.tripadvisor.ca/Attraction_Review-g1061563-d547022Reviews-Canadian_National_Vimy_Memorial-Vimy_Pas_de_Calais_Hauts_de_France.html

${ }^{64}$ What is interesting to me is the disproportionate number of English to French reviews; taking into consideration that Vimy Ridge is in France but is also frequented by British and Australian tourists (according to their reviews on TripAdvisor).
} 
emotional visit." ${ }^{\prime 65}$ This traveller's sentiments were shared by many other reviewers on TripAdvisor, some referring to the memorial as "important" and "moving."

Though they are far less frequent (only six "average" and four "poor"), the negative reviews of the memorial are equally important in understanding how people interact with it. Rationales for posting an average rating vary from review to review. However, one of the most common reasons referred to how "artificial" the space has become over the years. One review's title reads "Are we in danger of [turning] these places into 'Theme Parks'?"66 This particular visitor from the UK remarked that the site was extremely busy when they went in May 2015, due to a group of 500 students touring the site that day. This reviewer also remarked that the site's no dog policy was distasteful and that, overall, the site appeared too militaristic, likely a result of uniformed cadets patrolling the site and the privately hired security guard overseeing the activities of visitors.

The "Ypres Salient" is not a destination searchable on TripAdvisor. Indeed, "leper (Ypres)" is the term the website uses to encompass the Salient area. However, many of the memorial sites in the area have their own TripAdvisor pages and ratings. For instance, the Memorial Museum Passchendaele 1917 has 978 reviews, 789 “excellent," 166 "very good," sixteen "average," four "poor," and three "terrible," with 694 in English, 225 in Dutch, thirty-two in French, eight in German, and the remainder in other languages. ${ }^{67}$ Many of the "excellent" reviews discuss the realistic interpretation of war that the

\footnotetext{
${ }^{65}$ TripAdvisor, “Canadian National Vimy Memorial,” https://www.tripadvisor.ca/Attraction_Reviewg1061563-d547022-Reviews-Canadian_National_Vimy_MemorialVimy_Pas_de_Calais_Hauts_de_France.html.

${ }_{66}^{66}$ Ibid.

${ }^{67}$ TripAdvisor, "Memorial Museum Passchendaele 1917," https://www.tripadvisor.ca/Attraction_Reviewg1235453-d2191951-Reviews-Memorial_Museum_Passchendaele_1917-

Zonnebeke_West_Flanders_Province.html.
} 
museum boasts, and how informative and moving the museum is. ${ }^{68}$ The "average" and "poor" comments discuss a lack of accessibility for strollers and wheelchairs, and disappointing run-ins with crabby guides and shouting children. One went so far as to deem the museum as "not suitable for people with disabilities," mentioning that the exhibits are dark, the print fine and difficult to read, and noted a lack of chairs for guests to sit on when tired. Though many of the "excellent" reviews point to the merits of the museum as a site of remembrance, the more negative reviews focus on the amenities of the site.

The Passchendaele Canadian Memorial has sixty-four reviews on TripAdvisor. All except twelve reviews are in English, and it does not have any "poor" or "terrible" ratings. ${ }^{69}$ Similarly, the Saint Julien Memorial has 179 reviews, most "excellent" and "very good." The comments on these two sites echo the comments of the above locations; they discuss the sacrifice of soldiers, their structures, and how peaceful and contemplative the monuments are. ${ }^{70}$

Though only a glimpse into the experiences of visitors to these memorial sites, the TripAdvisor reviews assist in illuminating how the sites affect as sites of secular pilgrimage. The visitor's reviews also confirm Iles' point about the blurring of pilgrimage and tourism in the discourse used to describe some of their experiences as "moving," but also complain about the lack of access for persons with disabilities. Furthermore, the negative reviews, though there are few, reveal what amenities are missing from the sites.

\footnotetext{
68 Ibid.

${ }^{69}$ TripAdvisor, "Passchendaele Canadian Memorial," https://www.tripadvisor.ca/Attraction_Reviewg1235453-d8522194-Reviews-or5-The_Passchendaele_Canadian_MemorialZonnebeke_West_Flanders_Province.html\#REVIEWS.

70 TripAdvisor, "Saint Julien Memorial,” https://www.tripadvisor.ca/Attraction_Review-g188675d3211380-Reviews-Saint_Julien_Memorial-Ieper_Ypres_West_Flanders_Province.html.
} 
This is where conversations with battlefield tour operators were particularly impactful given that they visit and interact with these places frequently.

Liberation Tours' John Cannon and Phil Craig run a standard, blended World War I and World War II "signature" battlefield tour to France, Belgium, and the Netherlands, covering all the highlights including Vimy Ridge, Hill 70, Passchendaele, and BeaumontHamel. ${ }^{71}$ However, this is not wholly where their passions lie. When I asked them in 2019 where they preferred to begin their tours when they first started their company fifteen years prior, they started with the "smaller places [.... We would go to places like the Devonshires [Devonshire Cemetery]. If we went to Vimy, it was an after-thought. I don't think we ever looked at Vimy or Passchendaele as places to start. We've been there." 72 When asked for a rationale, they commented:

You have to go to the obvious place first, and a good example would be that a couple years ago we designed a First War only tour that was going to go to Verdun, Somme, Passchendaele and Vimy ... special tour. It included the Trail of the Caribou up to Belgium. ${ }^{73}$

However, Cannon and Craig offer more than a standard tour. During our phone conversation, they referred to something called "battlefield bashing," a phrase they used to describe the act of "walking the battlefields, going into the forests and kicking the dirt, and sitting by the monuments and reading, and walking cemeteries." ${ }^{74}$ Beyond that, Craig

\footnotetext{
${ }^{71}$ Liberation Tours, "Our Signature Tour - Fall Edition," https://www.liberationtours.ca/nwe-f.html.

${ }^{72}$ John Cannon and Phil Craig, interview by Breanna Lester, August 13, 2019.

${ }^{73}$ Ibid. The Trail of the Caribou is both a physical and metaphorical trail that connects each of the five battlefield memorials commemorating Newfoundland's First World War experience. Each of the five former battlefields are marked with identical bronze caribous: Beaumont-Hamel Newfoundland Memorial; Gueudecourt Newfoundland Memorial; Masnières Newfoundland Memorial; Monchy-le-Preux Newfoundland Memorial; and Courtrai Newfoundland Memorial. For more information on the exact locations and amenities of these sites, visit:

https://www.veterans.gc.ca/eng/remembrance/memorials/overseas/first-worldwar/france/BeaumontHamel/caribou-trail.

${ }^{74}$ John Cannon and Phil Craig, interview by Breanna Lester, August 13, 2019.
} 
mentioned interacting with the Beaumont-Hamel assemblage in a unique way. He said: "To jump over the fence at the back of Beaumont-Hamel to the German line - which you shouldn't be doing, but I do - and to pick up a Mauser rifle bullet that has been sitting there for 100 years, that's something different and on another level.." ${ }^{, 75}$ Craig's comment provides an understanding of the Beaumont-Hamel assemblage as more than just the site; it includes the "forbidden" areas around it as well.

Fields of Fire Tours proprietor David Patterson had similar experiences to share. His tours "would start in Paris. The original one was a two-week tour that would take you from beginning to end [of the First World War] for the Canadians to see all the major sites. ${ }^{, 76}$ One particular tour meant getting personal with the assembling landscapes. $\mathrm{He}$ said:

We had a trip where we had two vans and both vans got stuck in the middle of a field near Arras and there was a tractor and we asked if they would haul us out, but it ended up being quite the adventure for the clients because I said "go out in the field and find stuff" and they found within fifteen minutes twelve First World War shrapnel shells and we piled those up under the wheels of the van to get traction to get out of there [....] You'll see the piles of the shells in the corners of the fields in the Somme where the farmers pick them up and pile them up. The ones that have the fuse on the ends are duds, but there is still stuff inside them. You have to be careful with those ones. The hand grenades too. Shrapnel shells which are empty shell casings have nothing explosive left in it. When you walk the Somme battlefields which are still relatively undeveloped compared to Passchendaele, you'll always find something. People take them home with them as souvenirs. Someone on the foundation tour found an eight-inch shell that weighed twenty-five pounds. She ended up throwing out half her clothes to take it back with her in her luggage. ${ }^{77}$

Once again, tour operators traverse the scripted commemorative landscapes, but also find ways to interact with them in other, perhaps riskier ways. This again contributes to an

\footnotetext{
75 Ibid.

${ }^{76}$ David Patterson, interview by Breanna Lester, September 3, 2019.

${ }^{77}$ David Patterson, interview by Breanna Lester, September 3, 2019.
} 
understanding of battlefield landscape assemblages as more than the prescribed sites.

Patterson's story also highlights the ways in which the landscapes inhibit human interaction, especially when you stray from the specified areas. The presence of potentially live shells in the vicinity means that tourists are usually restricted to the constructed pathways. However, from the stories of both battlefield tour companies, the lesser-trafficked areas seem to be where the most affecting, embodied experiences occur.

Finally, these landscape spaces that essentially rely on human interaction must include necessary facilities such as toilets and nearby food outlets. While the larger sites such as the "Big Three" at the centre of this dissertation certainly include lavatories, and most have vending machines, many of the smaller destinations do not have either. This means that these battlefield tour operators must be aware of what is lacking in these commemorative sites and adjust to accommodate. David Patterson, whose apt words about monuments and Pokémon cards opened this chapter, is well-known at the Canadian Battlefields Foundation for knowing where the best toilets and restaurants are in the areas near these frequented sites. In our interview he indicated:

I tend to go back to places I know will be good. Sometimes it's hard to get twelve people into the same restaurant. I give recommendations for places that are good. There was one group where I spent a lot of time sending them recommendations before the trip because they were very concerned about where they were going to eat every night. A big bus, you have washrooms on the bus, but in a van, you have to make sure you know where the nearest facilities are and you have to explain to people what the customs are. You don't just walk into somewhere to use the bathrooms without buying something. Knowing where the McDonald's are is always ... not for the food, but for the bathrooms. McDonalds' always have clean bathrooms. ${ }^{78}$

Knowing the limitations of these commemorative sites is therefore critical to Patterson's work because he must cater to his clients to ensure they have the best possible

\footnotetext{
${ }^{78}$ David Patterson, interview by Breanna Lester, September 3, 2019.
} 
experiences. In this context, McDonald's must be included in Patterson's assemblage because, on the smaller tours, his clients need to have access to a reliable, clean toilet. Phil Craig and John Cannon of Liberation Tours expressed something similar in our conversation:

We have well-travelled guests. If it's a group lunch, it's a sit-down lunch with a starter, a main, and a dessert and a glass of wine and coffee. We make sure they have a choice of their main dish, and that is done to instill some comradery, and also, we like being in a remote area and we move from south to north (no doubling back) and we're on a schedule and we need to feed them and keep going, plus there's no options to eat anywhere, so we find them a nice restaurant and keep going. If there's down time like in Dieppe, for example, we let them loose on the harbourfront for two hours to choose their own restaurants. ${ }^{79}$

As these perspectives show, commemorative landscape assemblages are not just comprised of the sites themselves and their individual elements, such as monuments, plaques, parks, museums, and visitors' centres. For tourists and tourist operators, they also include the toilets and restaurants. Though the perspectives of battlefield tour operators proved invaluable in assisting my understanding of how these sites work as assemblages, I still felt it necessary to, on their advice, go and experience their affective power first-hand. Consequently, the next section draws upon my ethnographic fieldwork while touring Beaumont-Hamel, Vimy, and Passchendaele.

${ }^{79}$ John Cannon and Phil Craig, interview by Breanna Lester, August 13, 2019. 


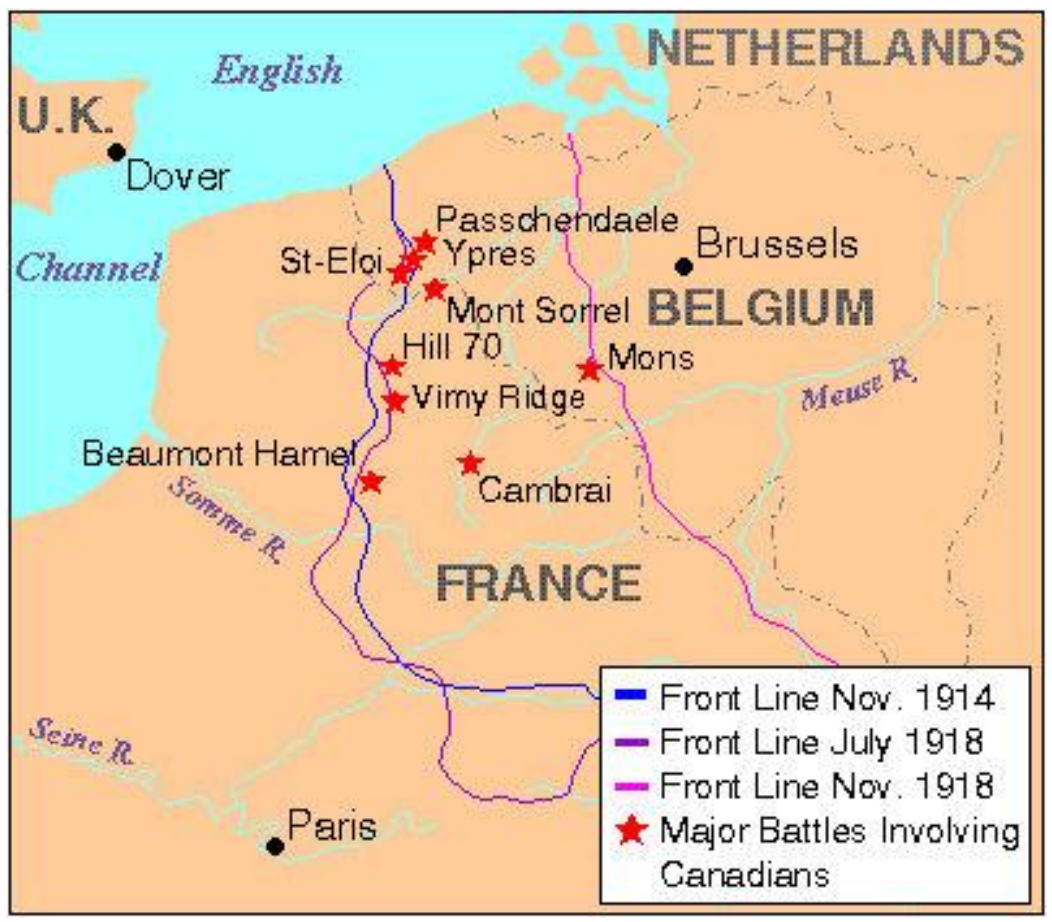

Figure 2.4. (above) - Map showing the locations of major Canadian battles of the First World War including Beaumont-Hamel, Vimy Ridge, and Passchendaele. There are currently official Government of Canada memorials at each of these sites. Image borrowed from the Canadian Encyclopedia. https://www.thecanadianencyclopedia.ca/en/article/vimy-ridge

Figure 2.5 (below) - Aerial image of the Beaumont-Hamel Newfoundland Memorial. Image courtesy of Veterans Affairs Canada.

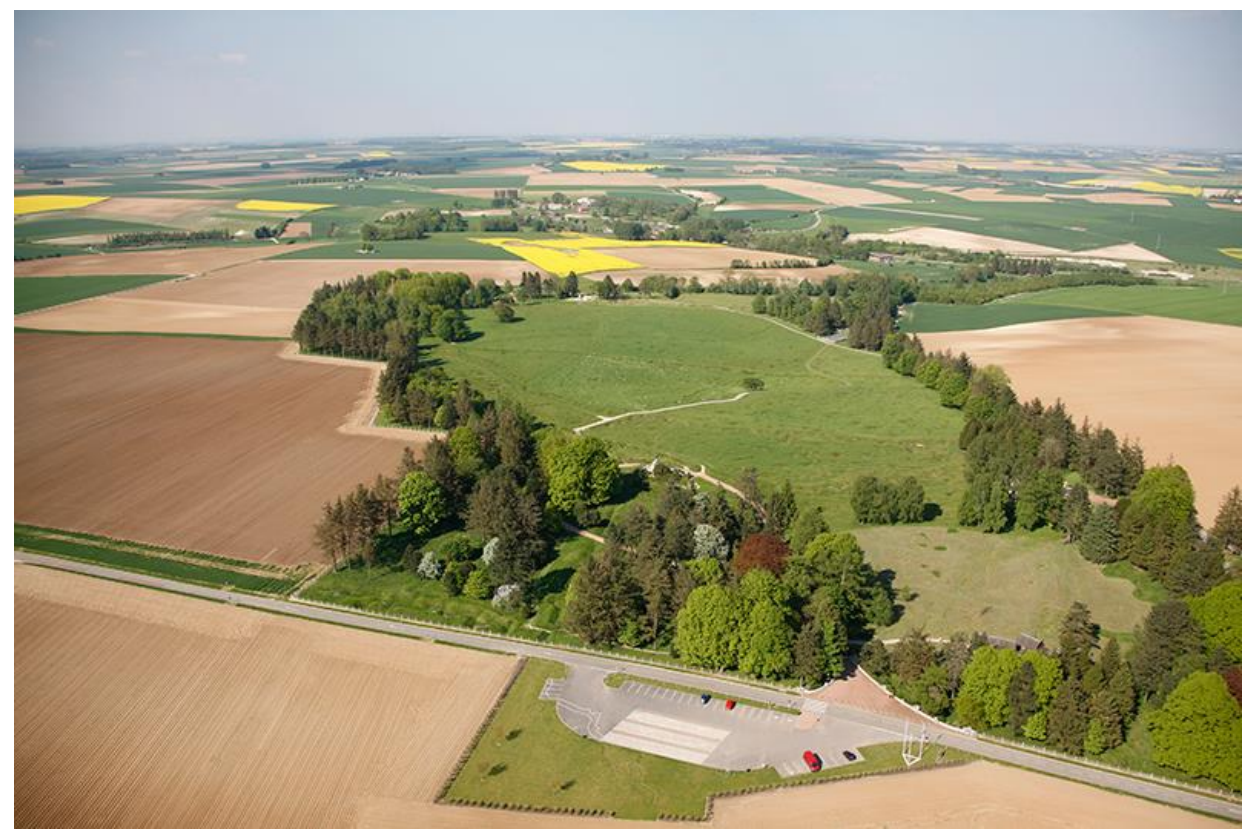




\section{$\underline{\text { Counting Footsteps to Danger Tree at the Beaumont-Hamel Newfoundland Memorial }}$}

Arriving at the Beaumont-Hamel Newfoundland Memorial in a rented Peugeot 108, I noticed picnic benches and signage warning patrons that eating, drinking, and smoking are prohibited on site. However, next to the benches was an unpreserved trench depression the placard adjacent referred to as the Uxbridge Road trench (see Figure 2.6). Leaving the carpark, we crossed the street to access the site and were swiftly greeted by James, a seventeen-year-old engineering CEGEP student from Montreal, Quebec. We exchanged pleasantries; he asked my partner and I where we were from before ushering us into the visitor's centre and museum to our right. The narrative of the museum chronicles one person, Private Francis Thomas Lind who, according to VAC's website, enlisted and left Notre Dame Bay, Newfoundland aboard the S.S. Florizel on October 3, 1914, went to Cairo in 1915, fought at Gallipoli, subsequently died on July 1, 1916 during the Battle of Beaumont-Hamel, and was interred on site in the Y Ravine Cemetery. ${ }^{80}$ The first gallery of the museum is outfitted to resemble a typical home of the era in Newfoundland: pastels on the walls; a Union flag hanging from the rafters; an empty Johnnie Walker crate on the floor holding the wood for the furnace; and a taxidermic caribou mounted to the wall. Also, on the walls are photographs of the Royal Newfoundland Regiment and Private Lind when he enlisted in 1914. Leaving the first gallery meant leaving for war, evident in the map of Newfoundland painted on the floor with a trail of red dots leading patrons across the lobby into the second gallery and ostensibly to the Western Front. This gallery discusses the campaigns of the RNR and

\footnotetext{
${ }^{80}$ Veterans Affairs Canada, "Canadian Virtual War Memorial: Private Francis Thomas Lind," Government of Canada, https://www.veterans.gc.ca/eng/remembrance/memorials/canadian-virtual-warmemorial/detail/2742936.
} 
ultimately chronicles the events of July 1, 1916, listing objectives and casualties. From there, patrons encounter a poem on the wall titled "Remembering," written, like all other plaques at Beaumont-Hamel, in French, English, and German. The closing phrase of T.S. Eliot's poem, "To the Indians Who Died in Africa," "Where a man died bravely At one with his destiny, that soil is his. Let his village remember" lingered with me as I walked into the final gallery of the museum: the memorial chapel. This section contains a Newfoundland Book of Remembrance, flags, and memorial quilts. Just before the lobby stood what appeared from a distance as a map of Newfoundland, but as I moved closer, I noticed the map was comprised of several small photographs of soldiers.

Leaving the museum, the path forked: to the right is the fastest way to the memorial and to the left, preserved trenches. As we walked, James explained the trench system used at Beaumont-Hamel: communication trench farthest back; frontline support trench in the middle; and the frontline trench. Though the frontline trench is the only one fully preserved, James pointed out where the other two trenches were as we passed. From the trench, the caribou memorial nestled atop his mound is prominent, standing at attention pointed at the German enemy. Once we exited the trenches, James pointed some three kilometres in the distance to demonstrate the objective for the RNR on the morning of July 1, 1916, then promptly pointed to a gathering of trees to the right where the German gunners were waiting to mow down the advancing Newfoundlanders. Then he asked us to participate in an experience I will never forget.

Danger Tree is almost as iconic a symbol of the First World War to Newfoundlanders as the caribou (pictured in Figure 2.6). Legend has it that Danger Tree was used as a marker by the RNR on the day of July1, 1916 as it was a midway point of 
No Man's Land and a gathering spot to regroup before advancing. Unfortunately, Danger Tree was in perfect sight of the German gunners; few RNR soldiers made it past Danger Tree on that morning. Though the tree that stands in its place at Beaumont-Hamel today is a replica, it is meant as a stark reminder of the War's destruction. James told us this story before asking us to take a moment of silence as we counted our steps from the edge of the frontline trench to Danger Tree. I counted 120 steps. 780 soldiers went forward, only sixty-eight turned up for rollcall the next morning. 120 steps forward.

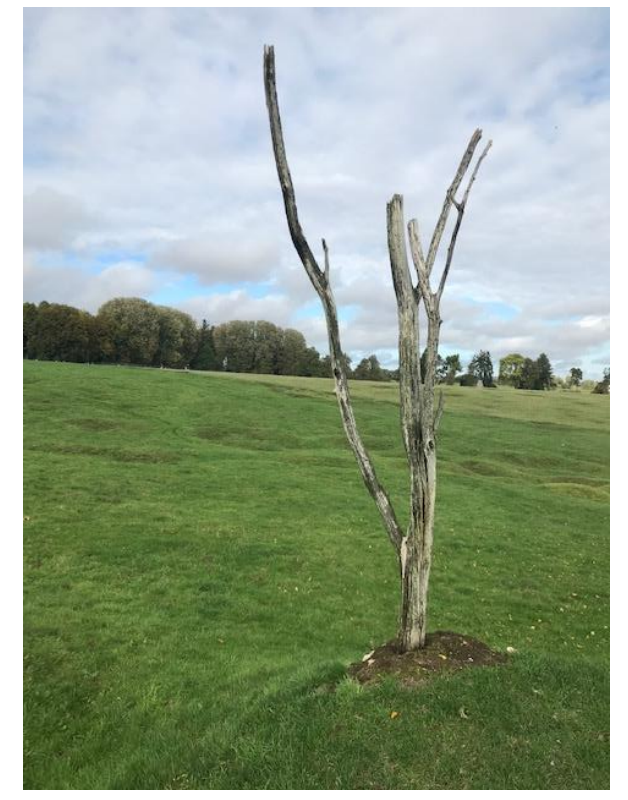

Figure 2.6-Danger Tree replica at Beaumont-Hamel. Photograph taken by Breanna Lester, October 2019.

Then James ended our tour. At that point, the trail leads forward in a loop that connects the Y Ravine Cemetery and 51st Highland Division Memorial back up towards the preserved trenches and the memorial. The bronze plaques containing the names of all known Newfoundlander casualties sits at the base of the caribou's well-manicured mound. Under the plaques are several wreaths, painted rocks, Canadian flags, crosses, and notes from home (see Figure 2.7). A narrow ramp leads from the base of the memorial near the plaques to the top of the mound. There is a structured path around the 
caribou itself where patrons can take in an incredible view of the entirety of the preserved battlefield (the caribou atop his mound is pictured in Figure 2.8).

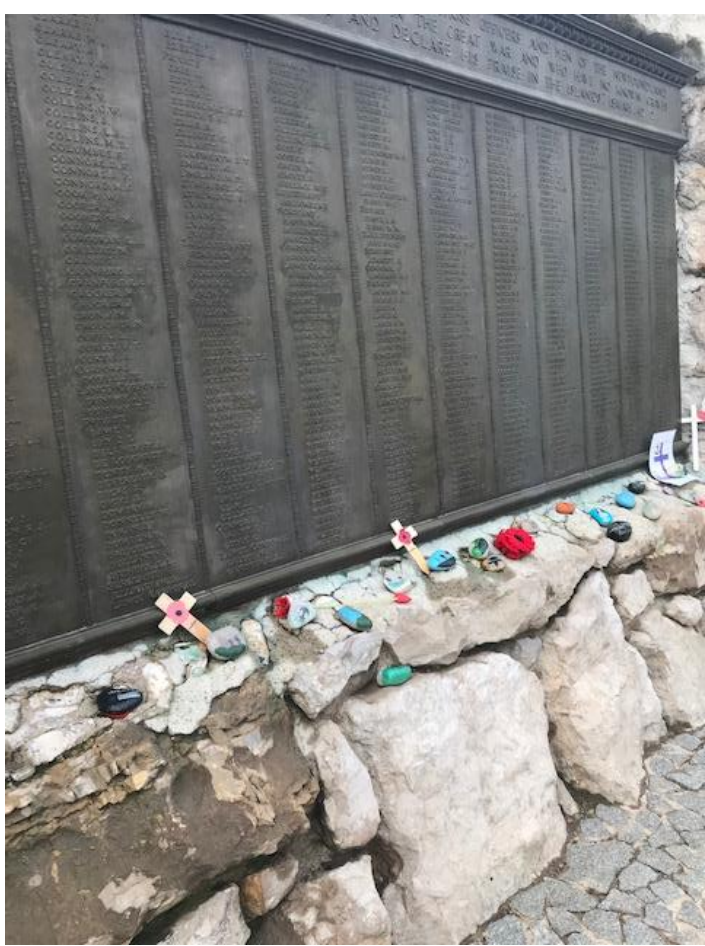

Figure 2.7 - Photograph of the bronze plaque etched with the names of all known Newfoundlander casualties of the Battle of Beaumont-Hamel. The tokens (crosses, poppies, coins, rocks) at the base of the plaque remind visitors of the sacredness of the site. Photograph taken by Breanna Lester, October 2019.

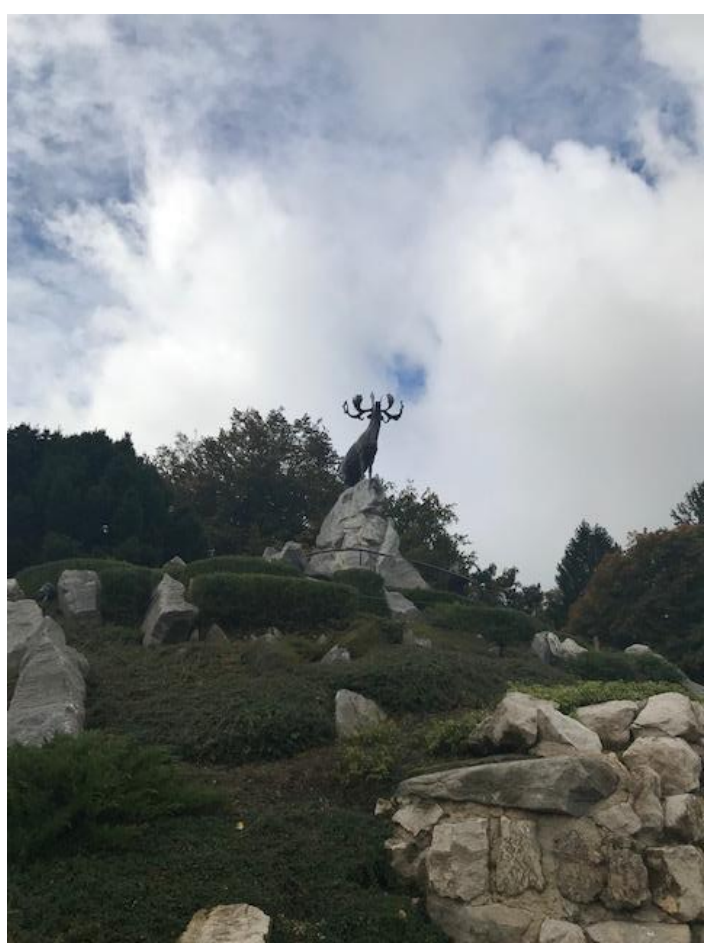

Figure 2.8 - Photograph of the bronze caribou atop its decorative mound. Photograph taken by Breanna Lester, October 2019.

Though I had the stories of Newfoundlander Doug Ballam's emotional pilgrimages to the site and the advice of battlefield tour operators in mind as I visited Beaumont-Hamel (more on this in Chapters Four and Five), I was not entirely prepared for my experience. Everything about the way visitors leave their vehicles and have to cross the street to access the park creates an immersive experience. The story of Private Lind, who travelled from his small town in Newfoundland to England, fought at Gallipoli, perished on July 1, 1916, and whose grave is on site creates this packaged narrative that is equal parts affecting and informative. Private Lind follows tourists 
through their experience, signaled by cues from the tour guides. Visitors learn of Lind's story in the museum, walk in his steps as he moved through the trench system, went over the top, died near Danger Tree, and found himself interred in the Y Ravine Cemetery further along. It is almost poetic the way the stage is set. Though it is, of course, intentionally performative.

The depressions in the Earth left by trench digging and heavy artillery appears to be one of the only true reminders of the passing of time and the destruction warring nations once imposed on the land. The site itself is perfectly maintained, and the paved pathways are aptly marked, their sides are lined with white posts connected by a chain that guides visitors along. However, the entrances to the trench and the caribou are narrow and steep, inaccessible to anyone with strollers, in wheelchairs or motorized scooters. The rambunctious and restless Swiss children in the visitor's centre made it evident that these spaces were not really meant for them; it is particularly unsafe for children to disobey the red warning signs on the other side of the tall parameter fences reminding visitors of the possibility of unexploded ordinance on site. Thanks to the sheep who maintain the landscaping on the inaccessible parts of the site, there is no overgrowth to be seen. 


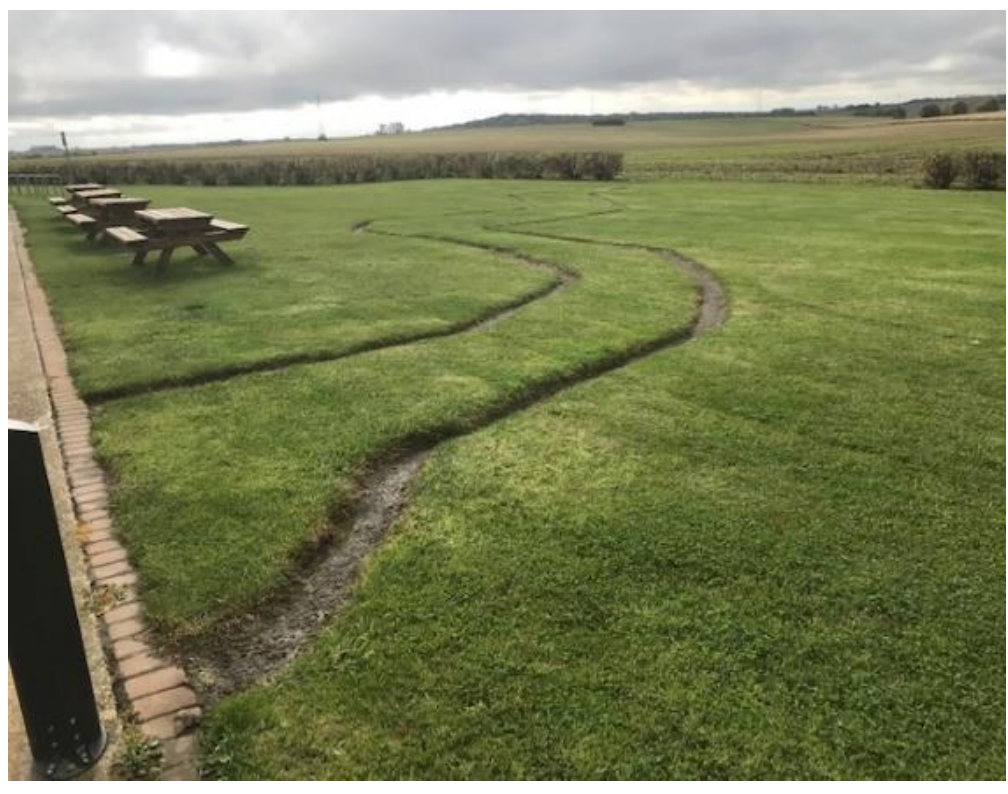

Figure 2.9-Photograph of the Unrestored Uxbridge Road Trench and adjacent picnic benches next to the car park at the Beaumont-Hamel memorial site. Photograph taken by Breanna Lester, October 2019.

While a large sign and flags in the carpark and elsewhere declare that BeaumontHamel Newfoundland Memorial is a Canadian National Historic Site, the narrative of the space insists that it belongs to Newfoundland's history and memory. This reflects the fact that Newfoundland was a British colony and not yet part of Canadian Confederation during the First World War. Beaumont-Hamel first emerged as a commemorative landscape for Newfoundlanders for the three decades after the war, since 1949 Beaumont-Hamel has been absorbed into a Canadian nationalist commemorative landscape. For example, of the eighteen tour guides (whom I later learned switched between Beaumont-Hamel and Vimy), only two in 2019 were from Newfoundland. According to the VAC website, the student guide program seeks "fifteen to eighteen dynamic students from across Canada." ${ }^{81}$ The guides must also be fluently bilingual in English and French. As satisfied as I was as a visitor to the site, I also left wondering if

\footnotetext{
${ }^{81}$ Veterans Affairs Canada, "Student Guide Program in France," Government of Canada, https://www.veterans.gc.ca/eng/remembrance/information-for/students/student-guide-program-in-france.
} 
the experience may have been made more special if the tour was hosted by a Newfoundlander.

As an assemblage, the Beaumont-Hamel Newfoundland Memorial landscape constructs and instructs. The pathways, for instance, were built where they were safely able, away from any potential unexploded ordinance (UXO). In this case, the UXOs dictate where visitors can safely walk and hence how they experience the site. Furthermore, together with the bronze caribou, Danger Tree controls the narrative, and though now a reconstruction, it marks the end of tours as it mythically marked the end of days for many Newfoundlanders during the Battle. At the site, both built spaces and things coexist, amenities and historical relics interact with each other, as evident in the mementos left at the foot of the caribou under the names of the fallen and the picnic bench next to the unrestored Uxbridge trench (see Figure 2.9). The placement of the bronze plaque dictates where offerings go, just as the placement of picnic benches instructs visitors where they can and cannot eat (Figures 2.7 and 2.9).

The Canadian National Vimy Memorial is visible from kilometres away as its crisp white stone shines from the top of the ridge overlooking the Pas de Calais region of Northern France. Though it appears close from the motorway, the site is approximately three kilometres off the N17 down Route des Canadiens. The rounded mounds and deep valleys were jarring; there is something uncanny about the warped yet turfed over landscape of these spaces. There are five carparks on the site, two on the west side near Canadian Cemetery No.2, one central in front of the visitor's centre (for buses), one across the street, and one on the north side of the site closer to the town of Givenchy and the Vimy Foundation Centennial Park. The Canadian National Vimy Memorial park is 
separated into two main sections: the monument, and the visitor's centre/trench experience. According to the self-guided tour map available inside the visitor's centre (Figure 2.10), it is recommended visitors begin in the open galleries and watch the documentary before signing up for a guided tour led by one of the student guides.

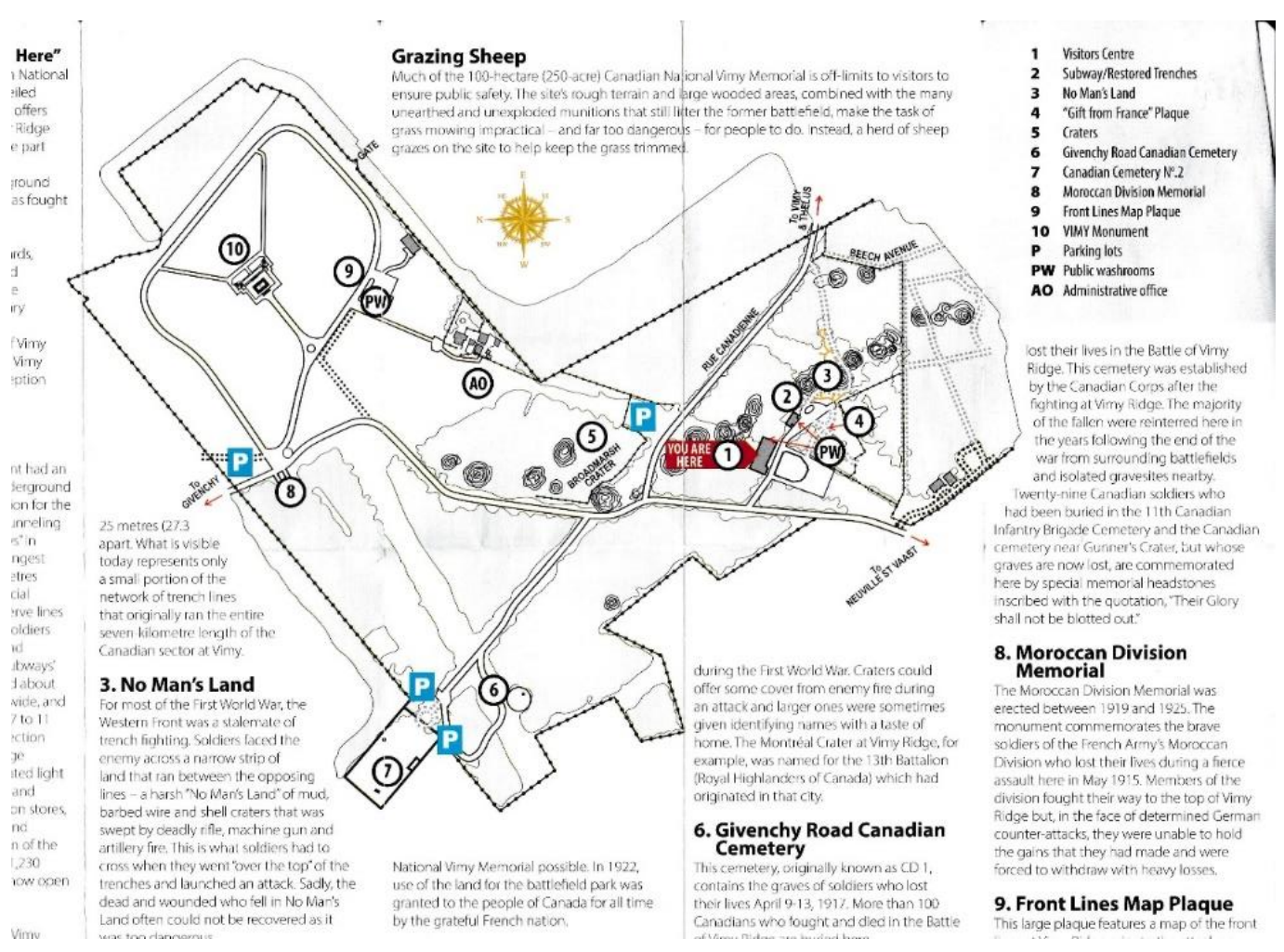

Figure 2.10- The map included in the self-guided tour brochure I picked up in the visitor's centre shows parking locations and highlights of the site including the cemeteries, trenches, and sheep.

Coincidentally, our tour guide from Beaumont-Hamel, James, was working at Vimy the day we visited. At the start of our tour, he explained the significance of the Battle of Vimy Ridge, the larger Battle of Arras, and rhymed off casualty statistics as he led us down into the tunnels. When down there, he demonstrated how dark the tunnels would have been without electricity by flipping a switch on the wall and asked us to 
imagine having to run supplies and information back and forth in the stark darkness we were experiencing. Once the demonstration concluded, James asked us to watch our step as we ascended the stairs to exit the tunnels in preparation for the next set of visitors to enter. Above ground, he asked if we had any remaining questions before jetting off to his next group.

We tried to follow the self-guided tour map (Figure 2.10) as much as possible to recreate a typical, scripted tourist experience at Vimy Ridge; we visited the 'Gift from France' plaque, walked past and photographed the craters, then crossed to the monument side of the park where we visited the Givenchy Road Canadian Cemetery and Canadian Cemetery No.2. According to the map, there are over 100 Canadians buried at Givenchy and 3000 commemorated in Canadian Cemetery No. 2. The identical white headstones row-on-row are permanent visual reminders of the cost of war. After reading some of the headstones' inscriptions, we crossed the carpark, passed the Moroccan Division Memorial, and started the ascent towards the Vimy Monument.

The monument itself is breathtaking and incredibly photogenic. The map explains the features of the monument, including a description and significance of its sculptures, information on the building materials, construction, and a short biography of the architect. When my partner and I visited in 2019 (once during the day and once the day after, right before sunset), the monument was abuzz with locals and tourists even though it was the end of October. Local joggers took advantage of the vast open space and clear pathways around the grassy amphitheatre and tourists grabbed selfies with the monument. As I learned from Visitor Experience Manager Ocel Dauphinais-Matheson, there are 
occasional visitors who endeavour to use the monument in ways some might consider disrespectful. He clarified:

It's a beautiful monument and so a lot of people see it as a free backdrop for all kinds of things: rap videos; half-nude photos; models or weddings. We can't monitor the monument $24 / 7$, but when we are here ... basically it is not telling people: "don't do it," it's saying "just understand where you are, what this means, and why it's important to respect this. It is a beautiful monument and would make a great picture if you were half nude on it, yes, but think about what it means. There's over 11000 names of missing soldiers on this monument." That's how we try and frame it to them. It's not "Don't do that!!" It's more like "Try and realize where you are right now." There aren't many forests. It's a lot of agriculture. This is the only real green space, so the locals use it as a green space. Most of them are very respectful. Joggers and so on: that doesn't bother us. Bicycles, though: we don't let people go on bicycles around the monument, so we're lenient so if you want to go for a nice jog, that's okay, but bicycles you can walk next to. It's a question of respect, right? ${ }^{82}$

Dauphinais-Matheson's job is to preserve the sacredness of the monument by dissuading inexperienced, ignorant, or disrespectful patrons from interacting with it in unintended ways. Part of this is to maintain its messaging as sacred space. There is also signage surrounding the green space of the monument reminding patrons of the rules: no overnight parking; no pets; no smoking; and a blue sign indicating that cyclists must dismount and walk their bicycles in the vicinity.

The Centennial Park is not included on the self-guided tour map, and I had to locate it on Google Maps using the free Wi-Fi in the visitor's centre because there is no apparent signage directing visitors to its location. The existence of a memorial park separate-but-adjacent to another memorial park is perplexing yet fascinating as it is representative of a larger Vimy assemblage than that prescribed in the self-guided tour map. As Figure 2.11 illustrates, the design of the Centennial Park always allows for the visibility of the Vimy monument, even when patrons are faced in the opposite direction

${ }^{82}$ Ocel Dauphinais-Matheson, interview by Breanna Lester, October 18, 2019. 
thanks to strategically placed mirrors. These mirrors literally reflect upon the monument. In our interview, Executive Director of the Vimy Foundation, Caitlin Bailey, explained the layout as follows:

It is also to encourage visitors to spend more time on the Vimy site because you can go now to monument, you can walk down to the visitor's education centre, there's a trench tour down there, and you can complete your circle now at the Vimy Foundation Centennial Park which abuts on to the Vimy Memorial on the eastern edge of the ridge [....] Constructing a park there gives visitors an extra contemplative space to think about the people who were there and the cost of the First World War and the people who participated in it in a natural environment. ${ }^{83}$

The concept of "completing a circle" is particularly intriguing from a landscaping perspective as it suggests a narrative in play, and due to its location, the Centennial Park is an effective ending point if visitors are following the self-guided tour which ends at the monument. The Park is also the newest addition to the landscape and a space that reminds visitors there are Canadians that still very much care about the First World War and Vimy Ridge and that, as an assemblage, it continues to evolve over time.

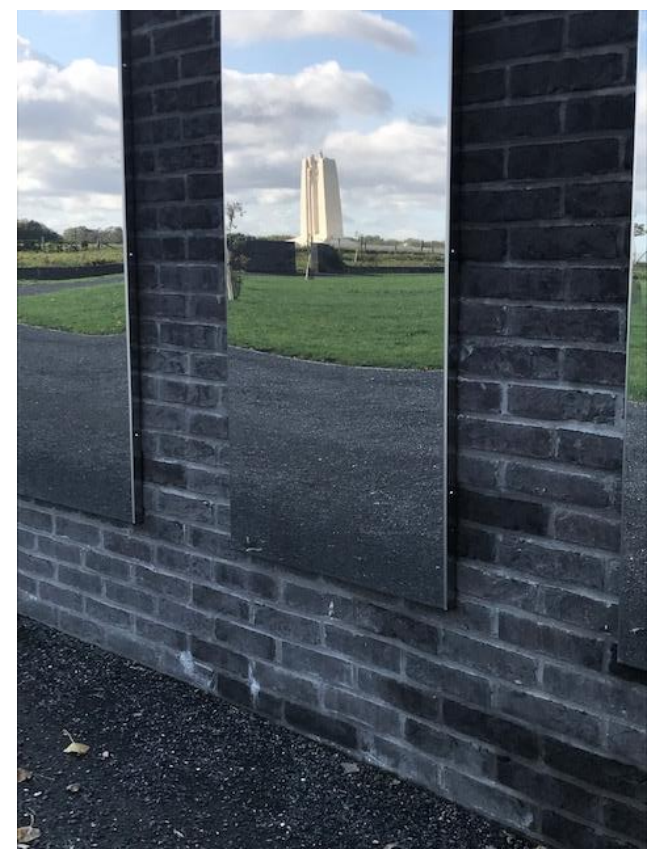

Figure 2.11 - Photograph of mirrors reflecting the Vimy Memorial from inside the Vimy Foundation Centennial Park adjacent to the National Vimy Memorial in Vimy, France. Photograph taken by Breanna Lester in October 2019.

${ }^{83}$ Caitlin Bailey, interview by Breanna Lester, July 24, 2020. 
We returned to Vimy the following day for a morning interview with Ocel Dauphinais-Matheson and a last look at the site before climbing back into our rental car and heading to Belgium. Given the Memorial Museum Passchendaele 1917's significance in the ATIP materials, this was our first stop. It was a misty day in Zonnebeke, but we felt it necessary to tour the memorial gardens and grounds of the museum before seeking refuge indoors. According to the pamphlet for the museum, the Memorial Gardens contain seven gardens dedicated to the seven major nations that experienced casualties during the Battles of Passchendaele: Germany, United States, Canada, Australia, New Zealand, the United Kingdom, and Belgium. Each garden is bound by red and black fencing, forming a poppy, and designed by its respective nation, centring on the theme of remembrance. Walking through the gardens was interesting in no small part because we finally encountered some German representation after having visited Vimy and Beaumont-Hamel where it is near impossible to locate any reference to Germany. I also enjoyed reading about and viewing the native plants of each country displayed within each poppy-shaped garden. However, after the thirty minutes it took to complete the tour of the gardens, I was thrilled to get out of the cold rain and into the museum.

As the focal point, the Memorial Museum Passchendaele 1917 aims to combine "the interactive design of a modern museum with the exceptional aspect of experiencing the Dugouts and Trenches." ${ }^{\circledR 4}$ After paying the entrance fee of $€ 10.50$, we collected our audio guides and moved through the museum at our leisure, listened to each segment carefully, explored the "unique Dugout Experience" which included frightening run-ins

\footnotetext{
${ }^{84}$ Steven Vanderbussche, Memorial Museum Passchendaele 1917: Experience. Reflect. Remember
} (Zonnebeke: MMP17, 2014). 
with life-size statues of British soldiers, before we headed outside to the "Trench Experience." Though we had already explored two trenches on our journey by this point, these trenches were refreshing because they were designed to indicate the stark differences between German and British engineering. I left wanting to add a book on trench production to my birthday wish list.

As recommended by a pamphlet we picked up at the tourist office located inside the museum, we headed to Tyne Cot cemetery next. As one of the largest Commonwealth cemeteries in the World, its impressive yet jarring design ensures that all CWGC gravestones are visible from any angle. According to the booklet, this cemetery contains 11956 graves and includes its own visitor's centre managed by the Memorial Museum Passchendaele $1917 .{ }^{85}$ Its existence certainly demonstrates the devastation of the Passchendaele experience and that is perhaps why the brochure suggests visiting it last after the Memorial Gardens and Museum.

However, Tyne Cot was not our last stop. Though we were losing daylight and had grown hungry, we decided to forgo visiting the Passchendaele Canadian Memorial (given it was identical to the Bourlon Wood Memorial we visited the day prior) and make a quick stop at the "Brooding Soldier" before heading into Ypres for that evening's Menin Gate ceremony. We first toured the Menin Gate while it was still light outside and then headed into Ypres' town centre for a Belgian beer, a snack, and a discussion of that day's events while we waited to queue for the ceremony.

It was not long before a massive crowd formed around the Gate; we were fortunate to get a spot within viewing distance of the ceremony. I filmed most of it while

\footnotetext{
${ }^{85}$ Vanderbussche, Memorial Museum Passchendaele 1917.
} 
my partner carried on a conversation about the ceremony with a local. Once over, we walked back into the square for dinner before driving out to Ledegem (twenty minutes from Ypres) for a night's rest ahead of our trip to Brussels (and a continuation of our vacation) the following morning.

My commemorative experience on the former Ypres Salient formed unique assemblages that included the Museum, Tyne Cot, "Brooding Soldier," Menin Gate, and Ypres, but also the weather conditions, discussions had in the car between locations, and the various pubs and restaurants we visited along the way. And as I discovered during follow-up interviews with David Patterson, John Cannon, and Phil Craig, there are other possible itineraries, and thus also other possible assemblages that tourists experience. Patterson's tours typically spend two days in the Passchendaele area. They visit Vancouver Corner, Langemarck German Cemetery, Essex Farm, Cloth Hall Museum, Hill 62, Crest Farm, the Canadian Passchendaele Memorial, and Tyne Cot Cemetery. For Patterson, the Memorial Museum Passchendaele 1917 is a bonus if time permits. Cannon and Craig visit Crest Farm, Hill 62, Tyne Cot Cemetery, St. Julien Monument, Menin Gate Memorial, and Ramparts Cemetery. For them, the Memorial Museum is "interesting...[yet]...stale," and they believe time is better spent in Ypres. All three tours (mine, Patterson's, and Liberation Tours) cover the same area, and yet each includes different elements which make up the unique assemblages.

Mapping them in situational maps, which appear in Figures 2.12, 2.13, 2.14, and 2.15 , assisted me in this realization. These situational maps are visual evidence that suggest the value of looking at commemoration through the lens of assemblage; no two 
experiences are the same and they include more than just the memorials and parks. And this is especially true for Passchendaele. 


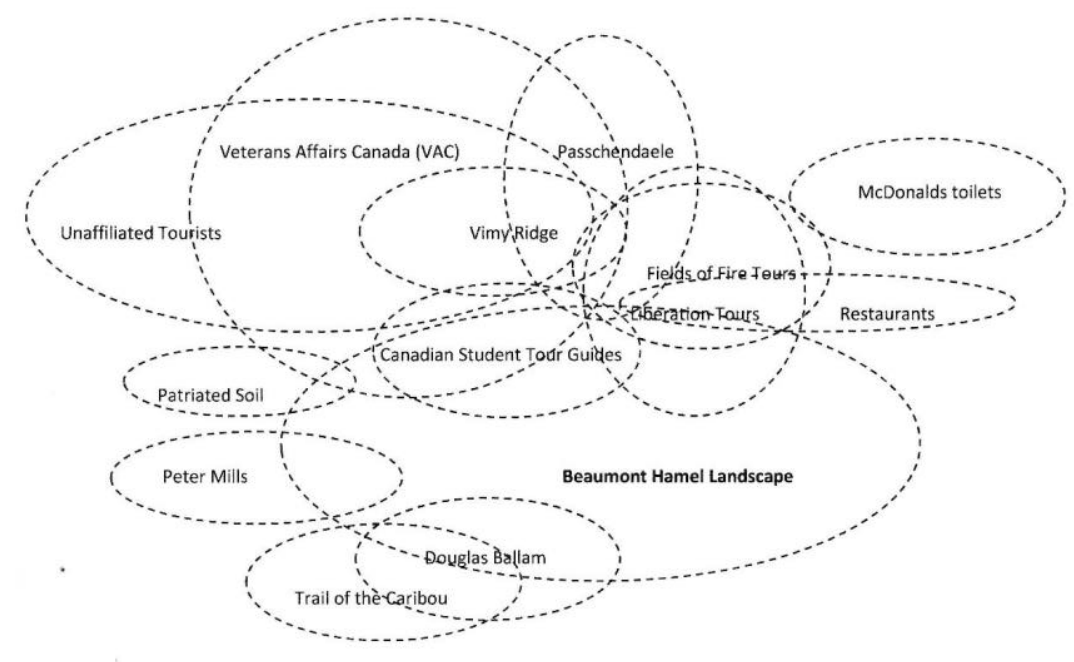

Figure 2.12 - Situational map of the Beaumont-Hamel Newfoundland Memorial assemblage. Indicates mobile entities that interact with the Beaumont-Hamel assemblage and other assemblages.

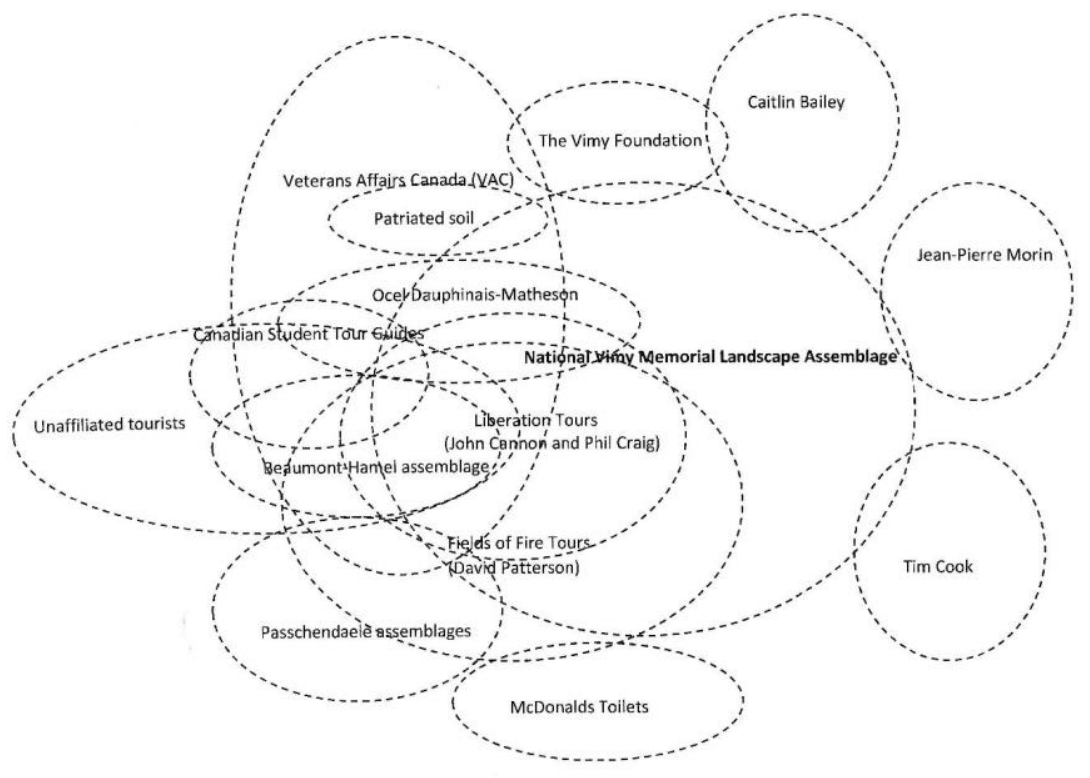

Figure 2.13 - Situational map of the National Vimy Memorial assemblage. Indicates mobile entities that interact with the Vimy assemblage and other assemblages. 


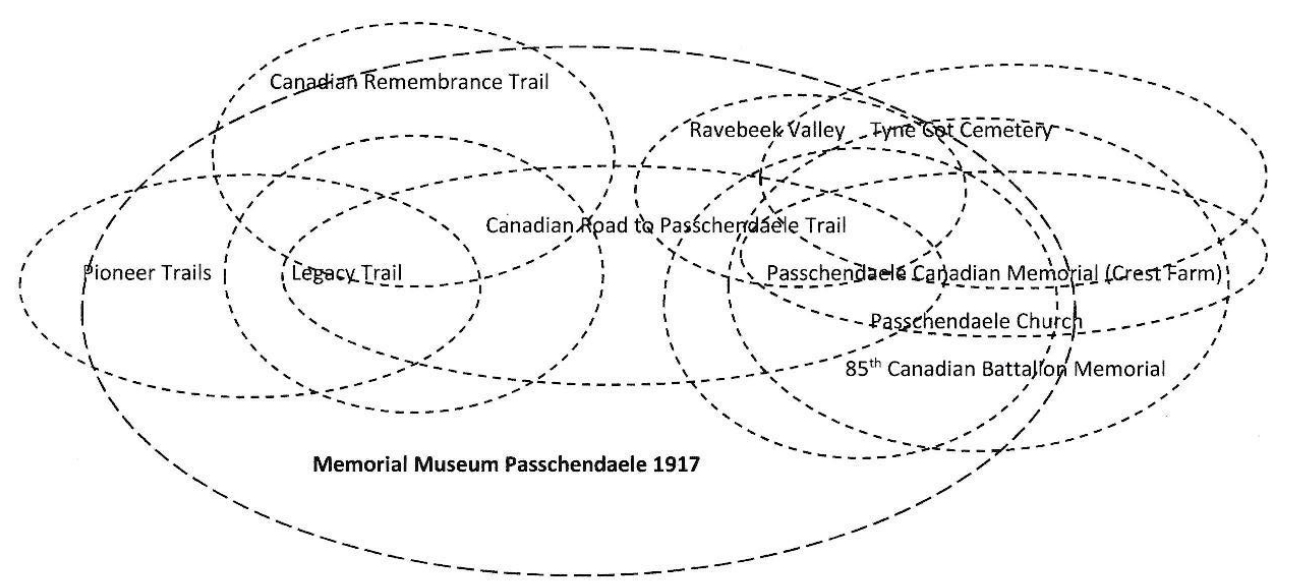

Figure 2.14 (above) and 2.15 (below) - Situational maps of the Passchendaele assemblages. Figure 2.15 was comprised based on the trails that connect the MMP 1917 with other sites. Figure 2.16 was assembled based on comments from battlefield tour operators and information gathered at the Memorial Museum Passchendaele 1917.

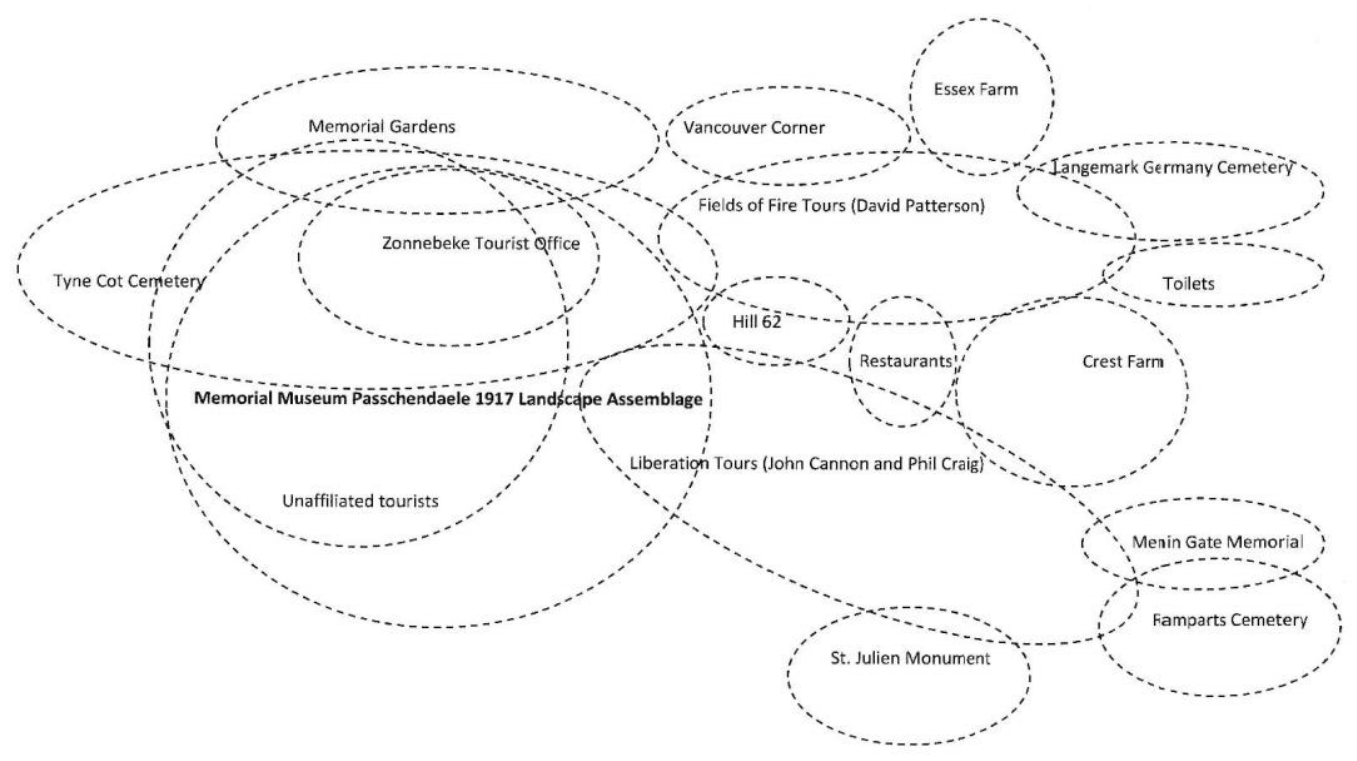


When analysed alongside Beaumont-Hamel and Vimy, Passchendaele is more an assemblage of sites rather than a single enclosed site like the other two. Though Passchendaele is elevated by the Government of Canada as one of the foundational battles in the forging of a Canadian identity, it is not a National Historic Site, and instead covers an area with many memorials erected by several countries. Furthermore, there were two Battles of Passchendaele, and this makes streamlined messaging difficult when attempting commemoration. But like the other two commemorative landscapes, Passchendaele is also experienced and made meaningful by the routes that one travels to, across, and away from the site.

\section{Trails}

Trails act as both tangible and intangible connectors between individual landscape assemblages. Tourism scholar Stephen Miles suggests that the purpose of commemorative trails is to "help disperse visitor spending," while also "stimulat[ing] memory and foster[ing] a deeper appreciation of the events of the war. ${ }^{\prime 86}$ Writing exclusively about centenary commemorative trails, Miles posits that "to move along a Remembrance Trail is to travel with purpose, focusing on one theme, and to allow a concentration of experience $[\ldots .$.$] This is made all the more powerful by the rhythms of$ mobility." ${ }^{87}$ Indeed, following a trail or route, whether on foot, on a bicycle, or by motorized transport, enriches the embodied commemorative experience. According to

\footnotetext{
${ }^{86}$ Though Miles employs the term "remembrance trails" to his study of trails along the Western Front, I believe "commemorative trails" to be a more appropriate term because of the temporal distance we now have from the First World War; Stephen Miles, "Remembrance Trails of the Great War on the Western Front: routes of heritage and memory," Journal of Heritage Tourism 12, 5 (2016): 442.

${ }^{87}$ Miles, "Remembrance Trails of the Great War on the Western Front," 447.
} 
Miles, trails also "afford an enhanced level of validity to sites," and create a "powerful synergy." 88

The Trail of the Caribou is a good example of the ways in which these trails operate. According to the VAC website, the Trail of the Caribou is the informal name given to a commemorative trail that physically connects the five caribou statues that stand on the sites of "some of the most important moments in Newfoundland's First World War experience." ${ }^{89}$ The trail connects Beaumont-Hamel Newfoundland Memorial, Gueudecourt Newfoundland Memorial, Masnières Newfoundland Memorial, Monchy-lePreux Newfoundland Memorial, and Courtrai Newfoundland Memorial (see Figure 2.16 for a map of these locations). However, according to their website, to visit all five sites, visitors require their own transportation as there is currently no public transportation that connects them. These visits also require three hours in good weather conditions. ${ }^{90}$ Though the Trail of the Caribou is not walkable, it featured prominently during the centenary. In a letter dated February 8, 2017 from the Premier of Newfoundland Dwight Ball to Kent Hehr, Minister of Veterans Affairs, Ball discusses Honour 100, an initiative "designed to highlight Newfoundland and Labrador's First World War story." most successful event, according to Ball, was the Trail of the Caribou. Ball describes this initiative as "enabling an enhancement of the annual Beaumont-Hamel pilgrimage [....]

\footnotetext{
${ }^{88}$ Miles, "Remembrance Trails of the Great War on the Western Front," 447-448.

${ }^{89}$ Veterans Affairs Canada, "Trail of the Caribou," Government of Canada, https://www.veterans.gc.ca/eng/remembrance/memorials/overseas/first-worldwar/france/beaumonthamel/caribou-trail.

${ }^{90}$ Ibid.

${ }^{91}$ ATIP, Government of Newfoundland and Labrador, letter to The Honourable Kent Herr, Minister of Veterans Affairs. February 8, 2017.
} 
The delegation visit[ed] key Newfoundland battlefields in France and Belgium, including the sites home to the five caribou monuments." ${ }^{.92}$

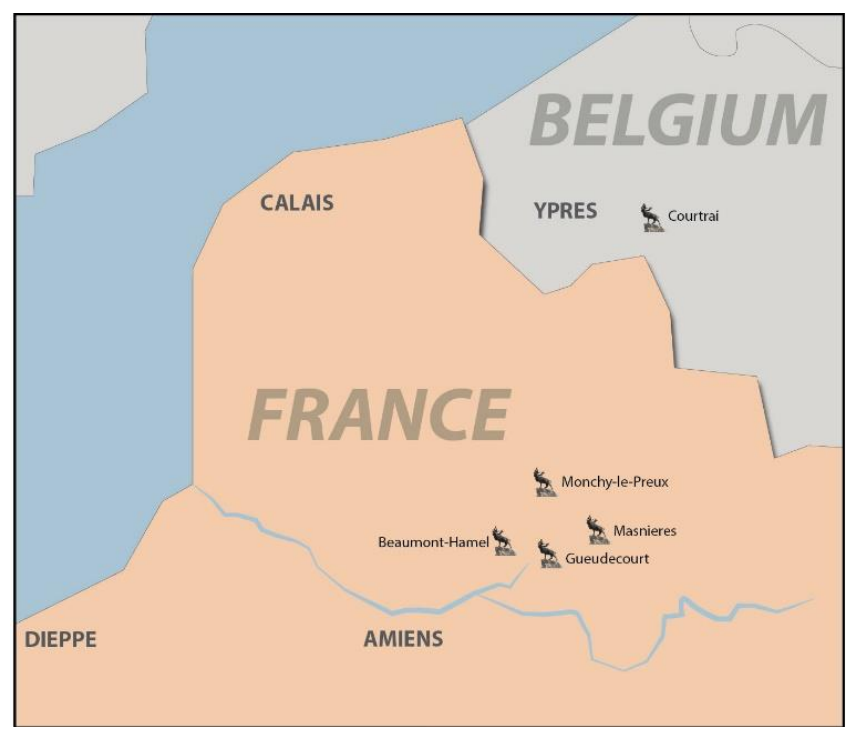

Figure 2.16 - Map of Trail of the Caribou locations in France and Belgium. Photograph courtesy of Veterans Affairs Canada. https://www.veterans.gc.ca/eng/remembrance/memorials/overseas/first-worldwar/france/BeaumontHamel/caribou-trail

The Trail of the Caribou is more than a physical trail. Its name appears on other commemorative entities including a CBC documentary released on July 1, 2016 called Trail of the Caribou which chronicles the journey of the Newfoundland Regiment through the Great War. ${ }^{93}$ As Newfoundland's provincial archive and museum, The Rooms' has a website that titles its section on the Newfoundland experience as "Trail of the Caribou." ${ }^{94}$ Doug Ballam's comments on the Trail illustrates this well. He said in our interview:

The Trail of the Caribou is metaphoric ... well not metaphoric ... there is one piece missing and that is Gallipoli in Turkey. It looks as if we will be installing a caribou there this fall [fall 2019]. It is in the works [....] For me, as someone who has been involved in pilgrimages for thirty odd years, nothing can be more

\footnotetext{
${ }^{92}$ Ibid.

${ }^{93}$ Canadian Broadcast Corporation, "Trail of the Caribou: Watch our full documentary online," CBC News, July 1, 2016, https://www.cbc.ca/news/canada/newfoundland-labrador/trail-of-the-caribou-1.3661371.

94 The Rooms, "Trail of the Caribou," https://www.therooms.ca/thegreatwar/at-war/trail-of-the-caribou.
} 
meaningful than finishing what was started more than 100 years ago and finishing what everyone recognizes as the gap in the Trail of the Caribou. ${ }^{95}$

The installation of a bronze caribou in Turkey would make physically completing the trail in a single trip an impossibility, however, it does speak to its metaphorical properties as Ballam illustrated above. Though it does not fit with the rest of the caribous in France and Belgium, erecting a bronze caribou at Gallipoli would complete the trail given it is the only remaining battlefield that is not yet adorned with a symbol of Newfoundlander participation. So, while each Trail of the Caribou memorial site remains its own assemblage, the Trail of the Caribou unites them and effectively narrates the Newfoundland experience in the War.

Passchendaele is also home to several commemorative trails constructed as part of VAC's centenary “Canadian Remembrance Trail." This was a $\$ 160000$ project that also included the publication of a Canadian-themed guidebook and further development of the memorial garden on the Memorial Museum Passchendaele 1917 grounds discussed earlier in this chapter. ${ }^{96}$ According to the "Canadian Remembrance Trail" brochure I found at the Zonnebeke Tourist Office inside the Memorial Museum Passchendaele 1917, there are three main trails which contribute to an understanding of the CEF's activities at in the area between 1915 and 1917: the "Legacy" cycling trail; "Pioneer" cycling trail; and "Pioneer" hiking trail. Legacy is a thirty-seven-kilometer loop that begins at the Zonnebeke tourist office and "introduces you to the monumental heritage of the Battle of Passchendaele." The Pioneer cycling trail runs thirty-eight-kilometer and is designed to educate visitors about the German perspective; discovering the "heritage of war" along

\footnotetext{
95 Douglas Ballam, interview by Breanna Lester, July 27, 2019.

96 The Great War in Flanders Fields, "Inauguration of the "Canadian road to Passchendaele' walk," http://www.wo1.be/en/news/52146/inauguration-of-the-canadian-road-to-passchendale-walk.
} 
the way. ${ }^{97}$ The Pioneer walking trail is shorter $(11.7 \mathrm{~km})$, but still substantial, and consequently covers an abbreviated version of Germany's Passchendaele experience during the First World War. ${ }^{98}$ Each of these trails begin at the Memorial Museum Passchendaele 1917 making it a commemorative nexus that connects many memorial sites together. Figures 2.17 and 2.18 show a map of the Passchendaele memorials in the Zonnebeke area, and a map of the "Canadian Road to Passchendaele" trail. Analysing the two together, readers can see the kinds of sites available alongside the trail.

The "Canadian Road to Passchendaele" seems to be the only Canadian-themed trail advertised in the "Canadian Remembrance Trail" brochure. An April 2015 article on the Westhoek tourism website discussed the inauguration of the $6.5 \mathrm{~km}$ "Canadian Road to Passchendaele" trail (Figure 2.18). The trail:

Retraces the Canadian soldiers' progression through the Ravebeek valley during the Battle of Passchendaele [...] passing by the 'Canadian Memorial Passchendaele' (Crest Farm) and the church, where the Battle of Passchendaele ended. The itinerary then continues through the rolling landscape and along the eighty-fifth Canadian Battalion Memorial and back to Tyne Cot. ${ }^{99}$

With Memorial Museum Passchendaele 1917 at the centre, these trails enhance the commemorative experiences of tourists by facilitating a more intimate relationship between people's bodies and the physical landscape. As historical geographer Matt Dyce argues in his article on the commemoration of the Athabasca Landing Trail in northern Alberta, commemoration is "a spatial practice of exchange, extending physically and mentally into the surrounding landscape, conveying and returning laden with historical

\footnotetext{
${ }^{97}$ Memorial Museum Passchendaele 1917, "Canadian Remembrance Trail,” 8.

${ }^{98}$ Ibid.

99 The Great War in Flanders Fields, "Inauguration of the 'Canadian road to Passchendaele' walk," http://www.wo1.be/en/news/52146/inauguration-of-the-canadian-road-to-passchendale-walk.
} 
value."100 Trails help facilitate this extension by both tangibly and intangibly connecting these sites together. In doing so, they also broaden the scope of each commemorative assemblage, creating new points of intersection and interaction.
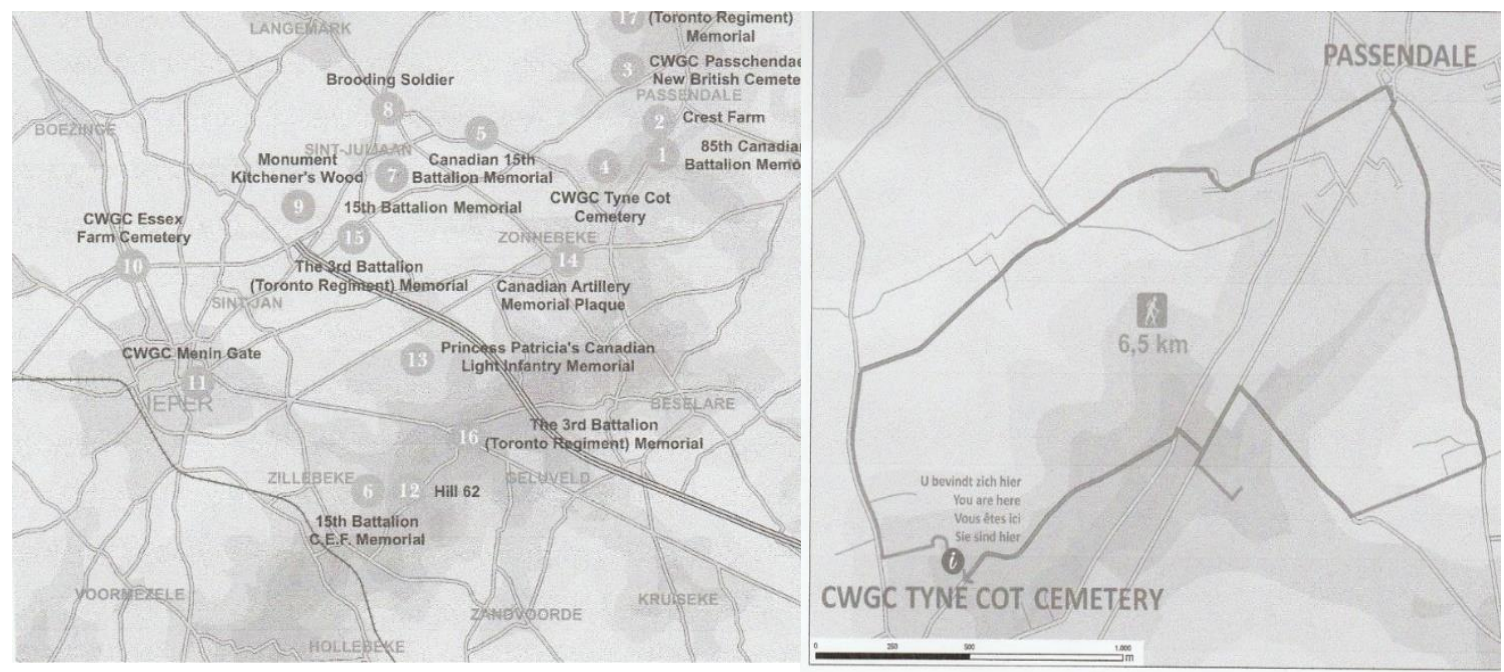

Figure 2.17 (left) and 2.18 (right) - Figure 2.17 is a map of the major Canadian Passchendaele memorials on the Ypres Salient. Figure 2.18 shows the route of the "Canadian Road to Passchendaele" trail. Images courtesy of the Memorial Museum Passchendaele 1917 brochure.

Some of the affective power of trails comes from the speed at which tourists travel while consuming them. For example, the Trail of the Caribou requires motorized vehicles such as a car or bus, whereas the Passchendaele trails are footpaths accessible on foot or by bicycle. Though time did not permit a three-hour drive through the Trail of the Caribou or a contemplative walk or cycle through the Passchendaele trails, my partner and I did a great deal of debriefing as we drove from location to location; we compared sites, shared our likes and dislikes, traded tidbits of information we learned along the way, and also communicated our hunger, need for a toilet, and our evening plans. While en route we were engaged in giving our site experiences reflection, meaning, and order,

\footnotetext{
${ }^{100}$ Matt Dyce, “'The Gateway to the Last Great West': Spatial Histories of the Athabasca Landing Trail,” Canadian Historical Review 94, 2 (2013): 180.
} 
but we also connected those encounters with the represented past to the other stuff of our everyday lives as tourists. In a general sense, the physical movement of bodies between spaces - whether by foot, bicycle, car, or bus - is important; the acts of making material connections with the ground and other things and discussing them afterwards should not be overlooked in studies of commemoration. Consequently, trails represent more than just lines on a map; looking at trails through the lens of assemblage situates them as powerful vectors in connecting sites together in one larger whole experience. They even connect sites that do not appear as "historically significant" such as a McDonald's with a reliable bathroom. Plainly, bodies who follow trails through commemorative spaces grow tired, get hungry, and need to excrete metabolic waste. These, too, are elements requiring more consideration by commemoration scholars.

\section{Place and Commemoration}

Catering to a home audience, centenary organizers had to get creative if they were to succeed in maintaining the First World War's importance to Canadians between 2014 and 2018. Discussing this phenomenon in a Second World War context, VAC Commemoration Division employee Robert Löken explained to me:

I will mirror the events that are happening overseas, so I'll use last year's D-Day ceremony that we had. We had a delegation overseas and they were doing ceremonies and events overseas. I had a delegation in Halifax, and we were doing similar ceremonies. Now obviously the visits were different because we are not going to military cemeteries, but from a ceremonial component, we were trying to incorporate some similar things so there would be a link between the two in that sense. ${ }^{101}$

VAC organizer Christina Gaudet also spoke of the intangible connections commemorators attempt to facilitate with the memorial landscapes of France and

${ }^{101}$ Robert Löken, interview by Breanna Lester, November 20, 2019. 
Belgium. When asked if an event like Vimy 100 could ever occur again on the same scale, she said: "You have people going to Vimy because it is Vimy. This is where they were, this is where their blood has grown the soil and if they did a thing like that in Ottawa, it's not the same. It doesn't have the same draw as when you do something overseas. They wanna see where they fought." ${ }^{" 102}$ Indeed, as I discovered from visiting these places, there is no substitute for being "where they were."

I first heard of this indefinable 'being on the ground' experience from reading Tim Cook's Vimy in which he describes the reaction he personally felt when standing on the grounds of Vimy Ridge looking up at the memorial. When we discussed that moment in our interview, he remarked, "I think walking the battlefields is a very powerful experience for people; you feel the weight of history there." ${ }^{\prime 103}$ He went on to describe the feeling of 'being on the ground' as not solely originating from the sites themselves. Though he describes them as "beautiful, but pristine", he suggests that it is learning the history of the battlefields that helps foster an emotional reaction when one is there in person. ${ }^{104}$ In this sense, one's education also contributes to one's assembled commemorative experience because, depending on what literature is consulted, travel plans can form differently.

Though Cook was the first person I heard discuss the feeling of 'being on the ground,' he was certainly not the only interviewee to mention it. CIRNAC historian, Jean-Pierre Morin told me that Vimy is "extremely beautiful. The way it has been manicured $[\ldots .$.$] It has a massive amount of solemnity which is not everywhere. { }^{" 105}$ Here,

\footnotetext{
102 Christina Gaudet, interview by Breanna Lester, January 22, 2020.

103 Tim Cook, interview by Breanna Lester, May 30, 2019.

104 Tim Cook, interview by Breanna Lester, May 30, 2019.

105 Jean-Pierre Morin, interview by Breanna Lester, July 5, 2019.
} 
Morin refers to the grassed-over craters and mounds left by artillery. In comparison to Menin Gate in Ypres, Morin observed that "The daily ceremony of the guards changing is part of the solemnity, but it is part of the city, so you can't imagine the horrors of the war in the same way because the city has been rebuilt. You go to Vimy, you still have the aspects of war and the countryside is there and you are towering over it." ${ }^{\prime 106}$ Battlefield tour operator David Patterson also mentioned this feeling of 'being on the ground' in his critique of the Vimy 100 ceremony. He attributed the perceived failures on April 9, 2017 to a lack of connection with the monument and grounds. He said: "The memorial was blocked off for days beforehand. You got to see it and be there on the day, so it was a shared experience with 25000 other people, but not much of a connection with the ground. You can't see the ground with 25000 people there. Turns out, [...] it is about the ground and going to the places where things happened." ${ }^{107}$ Certainly, the Vimy monument contributes to this embodied experience, but it is a connection with the soil and the ability to walk the grounds that really facilitates the affecting experience my interviewees describe.

The First World War battlefields do not look like they once did, and while the memorials are sometimes grandiose and magnificent, they are made of brick and mortar. However, several of my interviewees admitted to shedding tears or weeping at some of these sites. In talking about the Menin Gate ceremony, Ocel Dauphinais-Matheson commented, "Menin Gate? Oh, it's something. I shed a couple tears at that one because the fact that it's been going on for that long: every night since Armistice except during the Second World War. Every evening at 8pm they've been doing it? That is something

\footnotetext{
${ }^{106}$ Ibid.

${ }^{107}$ David Patterson, interview by Breanna Lester, September 3, 2019.
} 
special, and there is always so many people." 108 Additionally, Douglas Ballam admitted to weeping "numerous times at Beaumont-Hamel."109 Dauphinais-Matheson also mentioned that "the guides could tell you hundreds of interactions they had" where visitors became outwardly emotional. ${ }^{110}$ And on my own excursion to the Vimy site, I spoke briefly with a man from Winnipeg who had taken a side trip to Vimy while on vacation with friends. Without prompt, he shared with me that earlier that evening, he too had wept at Vimy. While the power of place in these commemorations is obvious, it does raise a question: is it possible to recreate the same embodied commemorative experience from afar? The evidence suggests people have long tried to do just that.

The movement of natural elements, especially vegetation, between Canada and the First World War commemorative sites is not unusual; as the histories of these sites suggested, from the start commemorators thought to transplant elements of Canada and Newfoundland. Cochius tried to establish a material connectedness through the importing of trees and shrubs from Newfoundland to Beaumont-Hamel, the same way the Vimy Foundation replanted oak trees grown in Canada in the Vimy Centennial Park. Similarly, soil, plants, and trees were brought from Canada to St. Julien to complete the "Brooding Soldier" and again in 2014 to decorate Canada's poppy garden at the Memorial Museum Passchendaele 1917.

The centenary also saw the patriation of materials, and specifically the patriation of soil. A VAC memorandum dated February 18, 2016 requested departmental permissions for VAC and The Rooms, Newfoundland to patriate soil from the Beaumont-

\footnotetext{
${ }^{108}$ Ocel Dauphinais-Matheson, interview by Breanna Lester, October 18, 2019.

${ }^{109}$ Douglas Ballam, interview by Breanna Lester, July 27, 2019.

${ }^{110}$ Ocel Dauphinais-Matheson, interview by Breanna Lester, October 18, 2019.
} 
Hamel Memorial site in France for commemorative purposes. ${ }^{111}$ This commemoration was proposed in the form of a ceremony in St. John's, Newfoundland on July 1, 2016. ${ }^{112}$ Though Beaumont-Hamel was gifted to the (then) Dominion of Newfoundland and Labrador, it is technically French soil and therefore subject to French law. ${ }^{113}$ This meant that diplomacy was involved to patriate soil from the former battle site. The issue of archeological permits and de-mining were further complications that needed to be explored prior to the approval of the soil patriation, as well as the laws surrounding the international movement of goods subject to the Canadian Food Inspection Agency's policies on soil and soil-related products. ${ }^{114}$ These, too are part of Beaumont-Hamel's assemblage.

A preceding letter from a representative of The Rooms' Campaign for First World War Commemoration justified the desire for soil from France with a statement that it "symbolically contain[s] the DNA of those Newfoundlanders and Labradoreans who were wounded or died in the First World War." ${ }^{115}$ A CBC article dated March 23, 2016 detailed the ceremonial purpose of the soil. The Rooms' CEO Dean Brinton stated: "We're going to fill an urn, we're going to bring it back to Newfoundland, and on the hundredth anniversary during the ceremony at The Rooms, during the remembrance

\footnotetext{
${ }^{111}$ ATIP, Veterans Affairs Canada, memorandum to Minister of Veterans Affairs, "Request for soil from the Beaumont-Hamel Newfoundland Memorial site." February 18, 2016.

112 Ibid.

113 Ibid.

114 Ibid.

115 The Rooms' campaign involved raising money to develop a permanent Royal Newfoundland Regiment gallery in The Rooms' exhibition space, a courtyard, and amphitheatre: https://www.therooms.ca/fww/firstworld-war-commemoration; Where Once they Stood we Stand: The Rooms Campaign for First World War Commemoration, letter to The Honourable Kent Herr, Minister of Veterans Affairs, Veterans Affairs Canada. November 25, 2015.
} 
ceremony, we're going to patriate that soil back to Newfoundland." ${ }^{116}$ CBC reporter Lukas Wall added that the urn would thereafter be displayed in a decorative arch in the contemplative area of the Royal Newfoundland Regiment Gallery at The Rooms for visitation. $^{117}$

Vimy 100 planners also proposed a patriation of soil. A memorandum dated June 18,2015 discusses a revised briefing note which asks for permission to patriate Vimy soil from France to CFB Borden for commemorative purposes. ${ }^{118}$ Though the ATIP returns produced no further information on the patriation of the Vimy soil, this event made local and national news. An article published in a May 16, 2016 issue of Barrie Today exclaimed that "For the first time in Canadian history, sacred soil recovered from a First World War battlefield in France will be repatriated" in a ceremony later that summer. The article goes on to say that the soil was excavated and moved in June 2015 and stored in an urn at CFB Trenton. The patriated soil was memorialised as part of a two-day vigil held at CFB Borden and interred in the new Borden Legacy Monument when it was unveiled on June 9, $2016 .^{119}$

CTV also reported on the patriation of the Vimy soil to the Borden Legacy Monument. In an article published on June 3, 2016, CTV reporter Aileen Doyle added that this was the first time that soil from another country was interned in a Canadian war

\footnotetext{
${ }^{116}$ Canadian Broadcast Corporation, "Beaumont-Hamel soil to be patriated during $100^{\text {th }}$ anniversary ceremonies," CBC News, March 23, 2016, https://www.cbc.ca/news/canada/newfoundland-labrador/frenchsoil-to-be-patriated-1.3503690.

117 Ibid.

118 ATIP, Veterans Affairs Canada, memorandum to Minister of Veterans Affairs, "A revised briefing note regarding a request for soil from the Canadian National Vimy Memorial for commemorative purposes at CFB Borden." June 18, 2015.

${ }^{119}$ BarrieToday.com, "CFB Borden making Canadian history with sacred soil collected at Vimy Ridge," https://www.barrietoday.com/local-news/cfb-borden-making-canadian-history-with-sacred-soil-collectedat-vimy-ridge-297023.
} 
memorial. Quoting Brigadier-General Carl Doyon, "To bring the soil back represents all of those people who trained and fought for the values that we share today." ${ }^{120}$ The notion of "bringing something back" is interesting because it connotes a sense of ownership, reclamation, and belonging. Perhaps for Canadians, patriating even a piece of the landscapes of Northern France provides solace that the former battlefield landscapes still belong to Canada and Newfoundland.

Especially with regard to Vimy, there exist several instances captured in the ATIP returns to "Bring Vimy back to Canada" and "Bring Vimy home." For instance, a slide deck prepared by Communications Consultant, Cindy Clegg, titled "Vimy 100 Vision" posits that the way to ignite momentum is through youth engagement. Aligning with the Canada 150 themes, VAC planned to "use [the] Canadian youth in attendance to "bring back Vimy' to Canada." ${ }^{121}$ A second reference is made to reclaim Vimy through the "Vimy Flight," a government-sponsored third-party program meant to "span the country from coast to coast, engaging with communities to commemorate our Canadian heroes of the past 100 years as Canada celebrates 150 years of nationhood."122 The "Vimy Flight" program, crafted to "bring Vimy home in their own unique way" was an initiative enveloped into the "Experience Vimy 100" proposal, sponsored by EF Tours, the Vimy Foundation, the Royal Canadian Geographical Society, and Sound Venture. ${ }^{123}$ The program's slogan, “A national learning platform to bring Vimy home” explicitly

\footnotetext{
${ }^{120}$ Aileen Doyle, "Soil from Vimy arrives in Barrie for centennial celebration," CTV Barrie, https://barrie.ctvnews.ca/soil-from-vimy-arrives-in-barrie-for-centennial-celebration-1.2930656.

${ }_{121}$ ATIP, Cindy Clegg, "Vimy 100 Vision," Cindy Clegg Communications. April 2016.

${ }^{122}$ Sound Venture, The Royal Canadian Geographical Society, The Vimy Foundation, and Education First, "Experience Vimy 100: A Proposed Project for Veterans Affairs Canada's Commemorative Partnership Program Community Engagement Funding Application," May 2017.

${ }^{123}$ Ibid.
} 
highlights this initiative's goal to reclaim Vimy. ${ }^{124}$ Though perplexing given Vimy was never "home" in Canada, these programs reflect a desire to connect the former warfront and homefront through the movement of physical bodies from Canada to Vimy and back again. In this regard, it represents another effort to establish both material and cultural connections through the practices of exchange and movement.

The importance of patriating soil from Canada's memorial sites in Europe is another revealing example of thing power. For some, the soil carries a sacredness and a connection to loved ones long since passed. As small parts of the commemorative landscapes in Europe, soil (interred in urns) is an extension of the powerful assemblages discussed in this chapter that act as a commemorative place for those who are not fortunate enough to visit the sites firsthand.

\section{Conclusion}

Due to their seeming likeness, there is a truth to David Patterson's description of many Canadian Great War monuments as "Pokémon cards" captured in this chapter's epigraph. However, to "collect" monuments is to dismiss them as passive even though they, together with their surrounding landscapes, form powerful assemblages that enrich our understanding of what commemoration is and how it works. Furthermore, despite the fact that many of Canada's First World War memorials look alike, to essentialize these memorials as things to be collected effectively removes the possibility that those who visit these commemorative spaces are not only gazing and collecting, but also feeling. Part of why commemorations can be so effective is because of the "where"; Patterson's

\footnotetext{
${ }^{124}$ Ibid.
} 
"Pokémon Card" monuments are made even less relevant if removed from their locations. Robert Löken understands the need for a connection to place which is why he tries so hard to establish tangible connections to these landscapes from Canada, and battlefield tours are less exciting if they are not picking up old shell casings or kicking up dirt in lesser-trodden areas adjacent to the prescribed commemorative sites. The "where" matters, and to diminish these spaces as passive is to minimize their role in the success of commemorative activities.

This chapter has focused on reframing landscapes not as inanimate things, but as part of active and affective landscape assemblages. They operate independently, but also with humans and other nesting assemblages whether geographically adjacent or not. Through an examination of how the landscapes of Beaumont-Hamel, Vimy, and Passchendaele came to be, an exploration of how people consume these sites through the reviews they write, in conversation with the battlefield tour operators who frequent these spots, and a look at the trails that connect them, complex and unstable assemblages form. These assemblages include things such as the toilets at McDonald's, restaurants, dirt, and shrubbery, in addition to the storied monuments that act as draws for tourists. It is important to add these elements to discussions of commemorations because, as this chapter has shown, they are centrally important.

As DeLanda writes: "Assemblages are everywhere, multiplying in every direction, some more viscous and changing at slower speeds, some more fluid and impermanent, coming into being almost as fast as they disappear." ${ }^{125}$ Consequently, looking at commemorative landscapes as assemblages is a complicated endeavour; it is

\footnotetext{
${ }^{125}$ DeLanda, Assemblage Theory, 7.
} 
impossible to capture a static assemblage. This was made particularly apparent in my earlier discussion of my tour itinerary as different from the ones Liberation Tours and Fields of Fire Tours follow. Therefore, the assemblages I discussed in this chapter are, like Kirk Savage's imaginary Washington Mall, unfinished; they only reflect my gaze as a researcher informed by the contents of my ATIP archive, my conversations with commemorative professionals, my own experiences, and what is available online.

However, a reconsideration of commemorative sites as part of greater landscape assemblages allows for an inclusion of more influences such as the more abstract commemorative bureaucratic work that occurs behind the scenes of commemorative events that I briefly introduced in my discussion of what is required to patriate soil. The next chapter unpacks these assemblages in greater detail. As I explain, there are practical logistics to consider in the planning and execution of events on these commemorative sites and, with such unpredictable, fluid assemblages working alongside planners, it is no wonder they find it difficult to produce flawless ceremonies if the literal foundations they work on are as unpredictable and ever-changing as this chapter has sho 


\section{Chapter Three: \\ Assembling Commemorative Work}

Focusing on major [commemorative] events ... it wouldn't be that different from event planning anywhere in the sense that you are looking at scope of event, care and protection of those participating, access to the event, program for the event, and making sure it is a significant program that resonates with those who participate, as well as including the communications component so people who don't participate in the event are made aware of the event and its significance, [and] the execution of the event on the day or days of [....] So, there's the planning and execution of events, the wrap-up afterwards with lessons learned, and then planning for the next one.

-Peter Mills, Director of Honours, Decorations and Medals, Office of the Secretary to the Governor General (former commemorations planner, Veterans Affairs Canada) ${ }^{1}$

\section{Introduction}

Though their subject matter differs, the commemoration scholars I point to in this dissertation's introduction, namely Kirk Savage, Jay Winter, and Martin J. Murray, seem to agree that commemoration is a necessary, politically sanctioned preserve of collective memory. ${ }^{2}$ And yet, there is also something banal about the process that is revealed in Peter Mills' epigraph to this chapter; once its ceremony is stripped away, commemoration is work.

Accordingly, this chapter takes seriously the quotidian bureaucratic labour that contributes to the successes of commemorative activities. It considers the labouring and human components of national commemorative events that occur behind-the-scenes, and in doing so contributes to a growing body of scholarly work that examines the day-to-day

\footnotetext{
${ }^{1}$ Peter Mills, interview by Breanna Lester, November 20, 2019.

2 Jay Winter, Remembering War: The Great War Between Memory and History in the Twentieth Century (New Haven: Yale University Press, 2006); Kirk Savage, Monument Wars: Washington, D.C., the National Mall, and the Transformation of the Memorial Landscape (Berkeley: University of California Press, 2009); Martin J. Murray, Commemorating and Forgetting: Challenges for the New South Africa (Minneapolis: University of Minnesota Press, 2013).
} 
efforts of public history workers. ${ }^{3}$ While the previous chapter explored the assembling landscapes of commemorations with an emphasis on the role of nonhuman entities in commemorative work, this chapter expands the lens of the assemblage to include everyday logistical entities - briefing notes, memoranda, emails, PowerPoint slides, and human actions. The focus in this chapter is directed towards a more human actor-centred perspective of commemorations as assemblages, and in doing so it demonstrates the affective experiences for those who do the labour of assembly.

This chapter is about commemorative work, and in pursuit of an accurate representation of the everyday labours of commemorative planning, it was important to consult the actual planning documents. As a result, I adopt a strategy recommended by Jiwani and Krawchenko who argued that combining analysis of Access to Information and Privacy (ATIP) materials with interviews of public servants provides necessary windows into the "backspace" of government. ${ }^{4}$ This chapter comes to a similar conclusion only with a narrower focus on VAC and its First World War commemoration activities.

The ATIP documents and supplementary interviews conducted about those documents reveal a side of commemoration less considered in the literature, one that highlights the centrality of logistics and the human labour involved. Indeed, the insights about commemoration derived in this chapter are less about nationalist historical

\footnotetext{
${ }^{3}$ I refer here to public historians like Amy Tyson whose book The Wages of History considers the ways in which historical interpreters at Minnesota's Fort Snelling understand and grapple with their daily work. Tyson discusses how the interpreters are altered emotionally and financially by the work they do. Amy Tyson, The Wages of History: Emotional Labour on Public History's Front Lines (Amhurst: University of Massachusetts Press, 2013).

${ }^{4}$ Farzana Nanji Jiwani and Tamara Krawchenko, "Public Policy, Access to Government, and Qualitative Research Practices: Conducting Research within a Culture of Information Control," Canadian Public History 40, 1 (2014): 62.
} 
metanarratives, identity, and memory, and more about how those goals both shaped and were affected by the logistics involved with planning commemorative events in support of them. ${ }^{5}$ Instead, this chapter offers a new dimension to the concept of the centenary of the First World War as assemblage, one based on the behind-the-scenes labour that makes possible the production of commemorative experiences. ${ }^{6}$ It therefore sheds light on a mostly unseen range of commemorative actors and practices that made possible the experiences of politicians, veterans, and audiences who were visible in the media coverage of the events. To do so, this chapter focuses on the archival traces of everyday and routine bureaucratic labour: PowerPoint slides; email correspondence; briefing documents; funding applications; anonymous letters; and promotional materials. Connecting these material things to the people and offices that produced and used them reveals a complex network of actors that belies any notion of a monolithic state acting as an undifferentiated whole.

This chapter first provides an overview of the initial planning phase of First World War commemorations at the federal level including a discussion of predetermined structures such as the Government of Canada's (and, by extension, VAC's) mandates, visions, and intentions for the centenary. These structures informed subsequent practical considerations and stakeholder relationships that contributed to the execution phase of the commemorative events. Next, this chapter explores what interviewees and the ATIP material refer to as the "post-mortem" process, that is the debrief of the event in its

\footnotetext{
${ }^{5}$ For works on these kinds of analyses, see Ian McKay and Jamie Swift, Warrior Nation: Rebranding Canada in an Age of Anxiety (Toronto: Between the Lines, 2012); Dan Todman, The Great War: Myth and Memory (London: Bloomsbury, 2007); Jay Winter, Remembering War: The Great War Between Memory and History in the Twentieth Century (New Haven: Yale University Press, 2006).

${ }^{6}$ Manuel DeLanda, Assemblage Theory (Edinburgh: Edinburgh University Press, 2016), 3.
} 
aftermath. The final section discusses how non-federal stakeholders navigated and contributed to the centenary alongside VAC planners, demonstrating again how assembly was a process that was not only about the federal state and its resources.

\section{The Initial Planning Phase}

The responsibility for military commemorative events was appointed to the Minister of Veterans Affairs Canada (VAC) in a Privy Council Order (P.C. 5371) passed on October 5, 1951 and solidified in a Privy Council Order (P.C. 1965-688) on April 13, 1965. The 1951 Order mandated VAC's responsibility for the overseas memorials and "Vimy Park." The second Order identified that as of 1965, "responsibility for many matters relating to remembrance of the war dead ha[d] not been specifically allotted." Consequently, the Order indicated VAC as the obvious choice to undertake the responsibility of commemoration because "the Minister of Veterans Affairs already has, by virtue of several Orders in Council and other authorities, or by agreement, certain specific responsibilities in this field and this type of responsibility complements naturally his obligations in the administration of virtually all of Canada's legislation for veterans." From 1965 onwards, VAC was the leading government department on all Canadian military commemorations. ${ }^{7}$

Since 1965, VAC has managed a regular rotation of anniversaries because, as celebrations scholar Peter H. Akyroyd writes in The Anniversary Compulsion (1992), "celebrating anniversaries is a categorical imperative." Accordingly, all First World War

\footnotetext{
${ }^{7}$ Order in Council of Canada, 1965, Commemoration Order of 1965, P.C. 1965-788. https://www.veterans.gc.ca/pdf/about-us/reports/9650413p.pdf.

${ }_{8}$ Peter H. Akyroyd, The Anniversary Compulsion: Canada's Centennial Celebrations, A Model MegaAnniversary (Toronto: Dundurn Press, 1992), 12.
} 
events deemed important by VAC organizers - namely the Battles of Beaumont-Hamel, Vimy, and Passchendaele, as well as the Armistice (commemorated as Remembrance Day), are performed year after year by necessity. This means that, while special commemorative dates such as twenty-fifth, fiftieth, seventy-fifth, and hundredth anniversaries require the most administrative work, ceremonies at the three battle sites must also be planned for every July 1, April 9, November 10 (to commemorate the end of the Battle of Passchendaele), and November 11, an effort that creates an annual commemorative calendar. This schedule is maintained by the Interdepartmental Commemorations Committee (ICC). CIRNAC historian, Jean-Pierre Morin explained: "The Interdepartmental Committee met once a month. In peak times, it met twice a month. The sub-committee met weekly [.... If you were a department that was planning an event like DND [Department of National Defense] and VAC, they were constantly coming to give updates as to what was happening, so the other departments could comment on what was missing and where they were needed." Accordingly, the ICC is responsible for maintaining the commemorative calendar that VAC personnel refer to as their five-year cycle. ${ }^{10}$

All the above-mentioned anniversaries require pre-planning. Following their fiveyear rule, VAC began initial commemorative planning for the centennial in 2010. In our interview, VAC planner Christina Gaudet confirmed that the initial meeting for the First World War centennial was in $2010 .{ }^{11}$ She distinctly recalled when the meeting occurred

\footnotetext{
${ }^{9}$ Jean-Pierre Morin, interview by Breanna Lester, July 5, 2019.

${ }^{10}$ Christina Gaudet, interview by Breanna Lester, January 22, 2020; Peter Mills, interview by Breanna Lester, November 20, 2019.

${ }^{11}$ Christina Gaudet, interview by Breanna Lester, January 22, 2020.
} 
because she was in the hospital recovering from knee surgery when she was notified. ${ }^{12}$ Peter Mills also provided insight as to when planning began when he mentioned to me that "there were discussions at the four-year mark before Vimy [in 2013] [....] There were initial discussions around concept and further analysis of what had happened on the ninety-fifth [in 2012] and what we would want to achieve strategically for the hundredth."13

As part of this pre-planning stage, there was a consultation period in which current and former members of VAC's Commemorations Division discussed previous commemorations. For example, a meeting in September 2015 brought together "current and former staff of the Commemorations and European Operations Divisions to brainstorm about Veterans Affairs Canada's In-Canada and overseas commemoration of the centennial of the Battle of Vimy Ridge in 2017." ${ }^{\prime 14}$ A draft outline of the roles and responsibilities for Vimy's ninetieth anniversary was attached to a 2015 email from Director General of Commemoration Hélène Robichaud, as "something to chew on" for the 2017 Vimy centennial. ${ }^{15}$ The congregation of former commemoration planners not only ensures consultation and potential administrative continuity, it is also a chance to learn from former mistakes and workshop issues encountered during the previous events. The Beaumont-Hamel commemorations were also developed based on historical plans. An email and accompanying "Site Plan" for Beaumont-Hamel logistical considerations, such as the use of large screens on site and toilet placements, instructed that "certain

\footnotetext{
12 Ibid.

${ }^{13}$ Peter Mills, interview by Breanna Lester, November 20, 2019.

${ }^{14}$ ATIP, Michel Bourque, "Vimy 100 Strategic Considerations," Veterans Affairs Canada, October 6, 2015.

${ }^{15}$ ATIP, Hélène Robichaud, email to Michel Bourque, John Desrosiers, and André Levesque, September 8, 2015.
} 
areas of the site be opened for the public as occurred for the ninetieth anniversary commemoration. People stood during the ninetieth anniversary and this would again be the case with some limited seating." ${ }^{16}$ A note dated September 13, 2015 also commented that the ceremony at Beaumont-Hamel was, "based on the 2011 scenario [the ninety-fifth anniversary of Beaumont-Hamel]." 17

Other factors in the planning phase of a commemorative event are what VAC employees term "mandates" and "protocols." Government-led commemorations must adhere to set mandates or guiding principles that establish parameters for what is and is not acceptable or possible for any given anniversary. According to a slide deck presented to the Minister of VAC on August 27, 2013 titled, “The Great Wars Legacy: Canada's Duty to Remember," VAC's Great Wars Secretariat was broadly mandated to: "link to Canadian Heritage and broader GoC [Government of Canada] partners; working closely with Canadian missions abroad; building relationships with diplomatic representatives from other countries in Canada; and coordinate, synchronize, and disseminate information." ${ }^{18}$ As part of their commemorative strategy, VAC developed three pillars: Awareness and Promotion; Events and Commemoration; and Lasting Legacy. According to the Great War Secretariat, their Awareness and Promotion pillar involved the rededication of the National War Memorial, and the creation of permanent altars for the Books of Remembrance. ${ }^{19}$ To fulfil the second pillar, VAC planned twelve international events, eight events in Ottawa, and five "community" events to commemorate both the

\footnotetext{
${ }^{16}$ ATIP, Veterans Affairs Canada, "Site Plan - Beaumont-Hamel," February 6, 2018.

${ }^{17}$ ATIP, Government of Canada, "Scenario Note - Government of Canada Ceremony of Remembrance Courcelette Canadian Memorial," September 13, 2015.

${ }^{18}$ ATIP, Veterans Affairs Canada, "The Great Wars Legacy: Canada's Duty to Remember," August 27, 2013.

${ }^{19}$ Ibid.
} 
First and Second World Wars. For First World War international events, VAC concentrated commemorative efforts on Gallipoli, the Somme, Beaumont-Hamel, Vimy Ridge, Passchendaele, and the Armistice. ${ }^{20}$ Domestically, VAC planned to mark the hundredth anniversary of the Battle of Ypres (the St. Julien gas attack), the Battles of Vimy Ridge, Passchendaele, and the Armistice. VAC also planned to endorse community events by providing "support for local cenotaphs and monuments, support for community remembrance projects, [the] Bring them Home school program, [the] World Remembers project, [and the] Torch of Remembrance relay." ${ }^{21}$ Finally, VAC's third pillar, "Lasting Legacy" involved collaboration with the Vimy Foundation to erect a permanent education centre at the National Vimy Memorial in France that was to be unveiled as part of the centennial anniversary in $2017 .^{22}$

Part of the challenge in conforming to mandates is pivoting with a change in government. In 2015, five years after initial planning and a year after centennial events began, Liberal Party leader Justin Trudeau replaced Stephen Harper (Conservative) as Prime Minister, and with this change in power came adjustments to the commemorative program. One of the central focuses of the new Liberal government was an emphasis on Canada 150. For example, in a slide deck titled, "Vimy 100 - underpinnings," VAC discussed the Government of Canada themes for Canada 150: youth, diversity and inclusion, environment, and Indigenous reconciliation. ${ }^{23}$ The slide deck also broke down how the Vimy 100 commemoration aimed to align with these themes. For instance, under

\footnotetext{
20 Ibid.

${ }^{21}$ ATIP, Veterans Affairs Canada, “The Great Wars Legacy: Canada's Duty to Remember,” August 27, 2013.

${ }^{22} \mathrm{Ibid}$. Though this dissertation is not concerned with educational programming due to the sheer amount of information available on that topic, the World Remembers project, and the Vimy Education Centre are discussed in detail in other chapters.

${ }^{23}$ ATIP, Cindy Clegg, "Vimy 100 Vision," Cindy Clegg Communications, April 2016.
} 
the heading titled "Diversity and Inclusion - aligned with Canada 150 theme," the slide added that "Canada's diverse population is built partially through war [....] Vimy is symbolic of the price of freedom and nationhood to Canadians that can be introduced to wider audiences of newcomers to Canada and abroad." ${ }^{24}$

Indigenous reconciliation was another major initiative of Justin Trudeau's commemorative agenda, following the Truth and Reconciliation Commission's (TRC) presentation of its final report on the impact of Indian Residential Schools on Indigenous peoples in June $2015 .{ }^{25}$ To conform to this mandate, the Vimy 100 planning committee conceptualised the promotion and encouragement of "visible [I]ndigenous participation in Government of Canada activities by recognizing veterans and performers and creating new venues to showcase their contributions." ${ }^{26}$ Though the push to include Indigenous stories in this round of commemorations is necessary considering past attempts to actively exclude Indigenous participation and commemoration, there existed several complications and restrictions in carrying out the government's plans. Jean-Pierre Morin explained:

My primary role was to ensure Indigenous content was always included, how it was included, provide advice to departments that were undertaking the commemorations. At the same time, internally to my department, we were going to do the full-blown commemoration of Indigenous involvement in the World War I and World War II as a package, so because of the overlap, we were just going to do them as two facets of the same commemoration. We had planned to do events, work with Rideau Hall and the Governor General for some form of commemorative event like we had done for 1812. We worked with DHH [Directorate of History and Heritage], DND, and VAC to create materials. We

\footnotetext{
${ }^{24}$ ATIP, Cindy Clegg, "Vimy 100 Vision,” Cindy Clegg Communications, April 2016.

${ }^{25}$ Government of Canada, "Truth and Reconciliation Commission of Canada," https://www.rcaanccirnac.gc.ca/eng/1450124405592/1529106060525; While the issues are distinct, reconciliation also conforms to the ongoing Liberal Party mandate of supporting multiculturalism that begun with the adoption of a federal multiculturalism policy by former Prime Minister Pierre Trudeau in 1971. Ian McKay and Jamie Swift, Warrior Nation: Rebranding Canada in an Age of Anxiety (Toronto: Between the Lines, 2012), 270.

${ }^{26}$ Ibid.
} 
did end up helping them create some materials. In the end, my department decided that this was not our file, that it should be VAC and DND leading it, so they basically cut all of our funding to do anything, so what we did was all we could do in-house without recurring any significant costs. So, we ended up creating a series of online content to actually promote knowledge of Indigenous participation in World War I and World War II. It was a thematic approach dealing with the different aspects of Indigenous involvement, dealing with the home front, the battlefield to heroes to impacts of the War afterwards on communities and things like that. ${ }^{27}$

According to Morin, though there were Indigenous components integrated into the commemorative plan that unfolded during the centenary, CIRNAC did not host its own Great War commemoration.

A slide deck prepared for an April 2016 briefing by a key stakeholder in the Vimy commemoration, Cindy Clegg of Cindy Clegg Communications, outlined a clear vision for Vimy 100. This vision prioritizes the Government of Canada's Canada 150 themes of youth, diversity and inclusion, and [I]ndigenous reconciliation. Aligned with these themes for Canada 150, Clegg wished to "highlight [the] multicultural dimension[s] of Canadian culture [and] values." ${ }^{28}$ Similarly, in a document titled, "GoC [Government of Canada] Plans for FWW [First World War] Centennial," VAC discussed key commemorative messaging. In addition to the commemorative period between 2014 and 2020 representing a “unique opportunity for Canadians to reflect on our country's long and proud military history," it also commented on their contributions to the Vimy visitor's centre. It remarked: “This new centre will be a lasting legacy of the $150^{\text {th }}$ anniversary of Confederation and will make visitors' journeys even more moving and transformative, as they pay tribute to all those who served." ${ }^{29}$ This discourse is not only

${ }^{27}$ Jean-Pierre Morin, interview by Breanna Lester, July 5, 2019.

${ }^{28} \mathrm{Ibid}$.

${ }^{29}$ ATIP, Veterans Affairs Canada, “GoC Plans for FWW Centennial,” June 2013. 
evidence of the celebratory undertones of VAC's commemorative efforts, it also provides insight into how commemorative assemblages overlap with one another. In this instance, the overlap created an anachronistic historical moment in which the collective memory of the Battle of Vimy Ridge intersected with the collective memory of Confederation despite the two events being separated by fifty years.

The government's vision of including "environmental" connections with Canadian commemorations is perhaps a more obscure mandate than the others. Nevertheless, a 2017 pamphlet for the "Highway of Heroes Tree Campaign" made the connection between tree-planting and commemoration. Beneath the heading, "Protecting what they Fought for," the organizers wrote: "Those who serve in our military protect our land and our freedom; we must protect what they fought for." ${ }^{\prime 30}$ This statement accompanied several black-and-white photographs of Canadian military personnel interacting with nature. Also, within this pamphlet, the tree-planting campaigners stated, "As Canadians, we're proud of our values that guide us to respect green spaces and wilderness." ${ }^{\prime 1}$ This is an example of a careful, if still strained, attempt to unite Canada's military past with the Canadian wilderness. But it is revealing that this commemorative choice was coupled with VAC's vision to reduce its own administrative carbon footprint through the creation of more online rather than published-on-paper content. An emphasis on environmental impact became entangled with the commemorative efforts of the government to mark the First World War's hundredth anniversary ${ }^{32}$

\footnotetext{
${ }^{30}$ ATIP, Highway of Heroes Tribute, "Highway of Heroes Campaign," September 2017.

${ }^{31}$ Ibid.

${ }^{32}$ ATIP, Cindy Clegg, "Vimy 100 Vision," Cindy Clegg Communications, April 2016.
} 
In addition to following commemorative mandates, VAC officials must also adhere to protocol. According to the public servants I interviewed, all ideas for commemorative ceremonies must receive minister approval before they can proceed. This process ensures that national commemorations align with the political platform of whichever government is in power. However, the ministerial approval process is often long and arduous, and commemoration teams working within the Public Service do not have carte-blanche to do what they please. VAC employee Robert Löken discussed the importance of following protocols in our interview session together, protocols he had to learn after he assumed the role of National Manager for Honours, Awards, and Commemorations at VAC: "There's the protocol of the events themselves which are the ceremonial component. A lot of that has been established by the Canadian Armed Forces and for decades, this is how a ceremony rolls out. ${ }^{{ }^{33}}$ When in the planning stages of commemorative events at the national level, protocols must be considered and followed closely to avoid rejection of the briefing by senior management and subsequent delay. Löken's colleague, Sylvie Thibodeau-Sealy, also commented on the process of obtaining approvals throughout the planning process: "We would brief our minister's office weekly. It's about managing expectations of what we can do." ${ }^{34}$

When drafting a briefing for the minister, there are other practicalities beyond the various protocols that need to be followed to produce a successful plan for a commemorative event. Löken explained:

The first thing we go through is to essentially come up with the concept of what we want to be doing; is it going to be a one-off event/ceremony that we are going to be doing on one day and then it is done and over with, or is this a significant enough commemoration date where we want to bring in family

\footnotetext{
${ }^{33}$ Robert Löken, interview by Breanna Lester, November 20, 2019.

${ }^{34}$ Sylvie Thibodeau-Sealy, interview by Breanna Lester, December 10, 2019.
} 
members from veterans that fought during the First World War? Do we bring in youth into these? Is it a delegation of (whatever the number happens to be)? And then we develop a program over a period of a few days. Is it multiple events at different locations in the country? So, it really is a bit of that brainstorming of: where do we see ourselves developing a broader program? Once that has been put to rest ... and that involves taking a look at the history of what it is that we are commemorating: What is the significance to Canada? So, if we use Vimy as an example, it's built into the Canadian psyche; everybody is very familiar with the Canadians and what happened at Vimy, so it has a broader significance than a number of other battles and things to that effect. [....] So, once I've got all of that down, I start identifying with my team: Who are the partners we could be working with to build on this? 'Cause we can't do it on our own. There's a lot more players involved in these and it's not strictly a government-led initiative, but what are the other partners who are already planning things because maybe in my concepts or ideas we have, someone else is thinking along the same lines or moved ahead on some of it, so how do we build with them as opposed to going at it alone and compete? So, I go through that whole process and submit that for review by our senior management and keeping my fingers crossed and they go 'yeah - that's a good idea' and then off we go to the races. ${ }^{35}$

Löken draws attention to the long process of drafting a program and having it approved before any of the practical elements are put in motion. He also alluded to the other potential partnerships that can form for any given commemoration. As I explain later, this broadens the scope of the bureaucratic assemblage that can also change as planning continues. However, beyond the unique protocols he had to familiarize himself with, Löken maintained that planning commemorative events is not so different from planning any kind of event; in fact, he said that he was initially recruited by VAC due to his extensive event planning experience in the hotel industry. ${ }^{36}$ In his words, "to be completely honest about it, an event is an event whether you're organizing a celebration or you're organizing a commemoration, the concepts behind it are ... as far as the work that needs to be done are very similar; an invitation is an invitation, booking a venue is

\footnotetext{
${ }^{35}$ Robert Löken, interview by Breanna Lester, November 22, 2019.

${ }^{36}$ Ibid.
} 
booking a venue -- those essentially are all the same." ${ }^{37}$ The next section looks at these

practical considerations in more detail.

\section{Logistics of Commemoration}

One of the most surprising revelations I experienced while working on this project

was learning just how many small practical logistical elements are involved in realising

large-scale, government-led national commemorative events. Perhaps the best

representation of the commemorative events assembly (in this case, the hundredth

anniversary of the Battle of Vimy Ridge) is explained in detail by Steve Harris. It is

worth considering in total:

The stuff that must be done are hugely complex. For example, where is the contingent going to stay? You've got to secure hotels. You are securing hotels in an area where there is going to be lots of competition because everyone knows something is going to happen at Vimy on the 9th of April, so everybody is going to be after the hotels in Arras. So, you have to find the hotels, and that's both a $\mathrm{VAC}$ and Canadian Forces issue. If you're taking a large contingent, you have to find a place to put 250-300 people and if you can't find 1 hotel that can take that many people and accommodate the fact that these people are going to have to get up at four in the morning to be ready to get on a bus at 5:30 to travel two hours to the site: they have to have breakfast at five and the hotel normally puts on breakfast at 6:30; you've got to work that all out. If you are carrying weapons for the guard, then you have to get the French Government to agree to your bringing weapons into the country. For Vimy 100 , we had the artillery pieces. You have to get the French government to agree to the storage of those weapons. Where? Under whose control? Under whose lock-and-key? If you're going to fire those weapons - even if it's blanks - you have to get French authorities to agree to the importation of ammunition for those weapons, and where are you going to store that stuff? The travel plan: you've got to get buses and those buses are going to travel along known routes at a time when ... there is an increased threat in France than there used to be. So, Forces protection becomes an issue. When do you need Gendarme outriders on your convoy? When do you simply need to let them know when you are going from A to B? How are you going to feed them at Vimy? If your base is in Mons and they're going to be there all day, how are you going to feed them? What are you going to feed them? Where are you going to feed them? If you have veterans with the contingent, these days it is mandatory because of their age that there is a caregiver. If there is a caregiver, is that caregiver mobile? Then you have to set up the schedules which are based, in

${ }^{37}$ Ibid. 
part, on the main events and whatever the host country may be doing in addition, or whatever allies may be doing in addition. For the hundredth of the Somme, there was a Newfoundland-Canadian focused event at Beaumont-Hamel, but there was a big British Commonwealth event at Thiepval, and what are the timings for each? And if Prince Charles is going to be at Thiepval at twelve and he's going to be there for two hours, what time do you have the Canadian event at Beaumont-Hamel if you hoped Prince Charles is going to be there? And what are you going to do if it rains? You can have the Canadian Forces contingent standing out there and they can get rained on, but if you've got veterans and veterans families there and you say "you've got to be at Beaumont-Hamel by noon because French security demands that roads are open only to Prince Charles from noon till whenever" and then you've got this crowd there and it pisses down rain. What are you going to do? ${ }^{38}$

Listening to Harris detail the considerations for a commemoration was dizzying; there are so many intricacies few people consider when examining large-scale commemorative events like Vimy 100. VAC planner Peter Mills contributed a French government perspective to the complexity of logistics in hosting overseas commemorative events at Vimy Ridge:

$\mathrm{VAC}$ is responsible for the management of Vimy proper (the grounds) however many hectares that make up the site, but everything beyond that piece of territory is French territory, so then you're required to deal with three levels of French government - the local level ... there are three communities adjacent to Vimy. So, you have mayors who are very engaged, concerned, interested in what's going to happen on a day like April 9th in their communities, the effects on their communities of that major gathering of peoples and equipment, and then you have a provincial level of Government, and then the federal government (Paris which controls police and fire and emergency services). Working with Global Affairs Canada, you need to manage and coordinate all of those layers being respectful of what you're told by French officials what you can and can't do. Your ability to do ... you want to do a fly past ... well that requires a very significant level of approval within French government ... you want to do drone footage, you want to set up any kind of infrastructure ... chairs, transportation, parking ... all of that requires approval within French government. It's a significant logistical and administrative effort, and not one that historically VAC has been funded to manage, so the requirements on human resources and on infrastructure resources you're required to contract is significant compared to what we would have done in the past. Security protocol changes depending on who you have coming, so when you have the French president, a security protocol affects that, but when you add royalty, it's an additional level of

\footnotetext{
${ }^{38}$ Steve Harris, interview by Breanna Lester, August 1, 2019.
} 
security protocol. Obviously, we have our own level of security protocol as well which must be respected for our Governor General and Prime Minister and all of the work that goes on to support that to make sure that that can happen ... so, an inordinate amount of coordination. ${ }^{39}$

I include the entirety of both Harris and Mill's retelling of the considerations involved in planning Vimy - though many of the considerations mentioned could apply to the planning of any international commemorative event - because it highlights the multitude of considerations planners must account for during this initial planning phase of commemorations. Together, their comments offer a more fulsome perspective of what commemorations are and how complex they are logistically as assemblages. As is implicit in Harris' and Mills' comments, this was an extremely cumbersome amount of work for VAC planners to manage and, as I discuss further in Chapter Five, it took an emotional toll on them as a result.

Included in this hectic planning phase is also a consideration of the timing of commemorative events beyond their historical anniversary. For example, it is considered ideal that Government of Canada commemorative events occur on a long weekend in summer to capture a large audience. A draft of the August 4, 2014 Ottawa launch event proposal for the centenary considered that the date fell on the Civic Holiday weekend meaning that there was more of an opportunity to attract tourists visiting Ottawa on that day. ${ }^{40}$ Fortunately for VAC planners, the British Empire declared war on August 4, 1914, providing a convenient date for a commemorative event 100 years later.

However, unfortunately for VAC planners, the commemoration of First World War battle sites is complicated by distance. For example, Beaumont-Hamel is in Northern

\footnotetext{
${ }^{39}$ Peter Mills, interview by Breanna Lester, November 20, 2019.

${ }^{40}$ ATIP, Veterans Affairs Canada, “August 4 - Ottawa Launch Event Proposal,” June 23, 2014.
} 
France and France is 4.5 hours ahead of St. John's, Newfoundland, meaning that VAC had to find an appropriate time for the ceremony in France that was suitable for both local considerations and also television coverage in St. John's. A briefing titled, “ $100^{\text {th }}$ Anniversary Commemorations - Beaumont-Hamel Newfoundland Memorial" communicated that "it would be preferable to hold the ceremony in the afternoon to allow direct broadcasting of the ceremony." 41 The time-distance challenges presented here show that the ceremony at Beaumont-Hamel was intended for viewing by Newfoundlanders, and less so for the rest of Canada considering the briefing did not mention the other Canadian time zones.

The schedules of involved dignitaries suited to attend commemorative ceremonies are also important in timing a commemorative event. The schedules of the Prime Minister and Governor General had to be accommodated due to the necessity of their presences at the ceremony to commemorate the beginning of the First World War. ${ }^{42}$ Furthermore, an awareness of other events occurring simultaneously is another important consideration. As event planners, it is important that your major event does not compete with other major events occurring in the UK and Belgium. ${ }^{43}$ This consideration speaks to a larger theme of this dissertation: the First World War was an international war and thus its commemorations were also international. This fact poses additional challenges in the Government of Canada's attempts to message the centenary as a national event, but as this evidence shows, it also added a considerable amount of work for the public servants

\footnotetext{
${ }^{41}$ ATIP, Veterans Affairs Canada, " $100^{\text {th }}$ Anniversary Commemorations Beaumont-Hamel Newfoundland Memorial," February 9, 2015.

42 Ibid.

${ }^{43}$ Ibid.
} 
whose job it was to coordinate with these other involved nations to ensure that neither a clashing of events nor a clogging of shared roadways occurred.

However, because of the nature of First World War battles, there are often other nations in competition for commemorative time at sites in the Beaumont-Hamel area. This was highlighted in a summary produced within VAC of the First World War Centenary Commemorations Meetings at the Foreign and Commonwealth Office in the UK held on September 2, 2015. The summary outlined five events that were to take place on July 1, 2016 in France: A British event held at Lochnagar Crater, Ovillers-laBoisselle; a ceremony at Thiepval by the UK and France; another ceremony at Ulster Tower by the Irish; a Canadian event at Beaumont-Hamel; and, finally, an unspecified German commemoration. ${ }^{44}$ Thiepval and Ulster Tower are in the same vicinity as Beaumont-Hamel and use the same roadways as access points, so it would be important for VAC planners to know when other events were taking place so as to not complicate access to their events. Again, it was vital to align logistical considerations with historical anniversaries.

As the mandated government body responsible for the planning of these events, VAC had many practical considerations to manage, but it is also important to understand that it does not operate in an administrative vacuum as it often partners and collaborates with other departments and external stakeholders. As Director of the Department of History and Heritage (DHH), Steve Harris has assisted VAC in a consulting capacity in its commemorative planning since the early 2000 s. He explained:

\footnotetext{
${ }^{44}$ ATIP, Veterans Affairs Canada, "First World War Centenary Commemorations Meetings: Foreign and Commonwealth Office," September 2, 2015. For perspective, Lochnagar Crater, Thiepval, and Ulster Tower are all within a ten-minute drive from the Beaumont-Hamel site and share many major autoroutes.
} 
Beginning about 2000 or 2001 , VAC decided to change the way it was doing overseas stuff and began coming to us to ask two kinds of questions: Who should be represented in the overseas military contingents? And increasingly historical background to help them organize these events [....] Toning down significances we see as our professional responsibility, but our job is to provide advice, and if it is not followed, well the people who don't follow it have the power not to follow it. ${ }^{45}$

Harris and his team are in-government historians, but they work in a wholly separate government department. However, they are constrained by the same federal mandates as VAC which pose issues that will be discussed further in the following two chapters.

As another historian-in-government similar to Harris, Jean-Pierre Morin of CIRNAC, occasionally works with VAC on commemorative endeavours. For example, Morin worked on the War of 1812 commemorations from 2012-2015 which was, as explained in this dissertation's introduction and further clarified in the next chapter, part of the Road to 2017 and therefore part of the World Wars commemorations. As I explained earlier, Morin's team did not end up hosting any commemorative events for the World Wars commemorations, his department and other departments including Harris' continued to offer support as participants in the ICC.

In planning for the First World War commemorations, VAC also collaborated with external stakeholders. Especially important was its partnership with the Vimy Foundation on the Vimy education centre. Christina Gaudet detailed the collaborative process between VAC, Public Works, and the Vimy Foundation in our interview. She said: "We had Public Works who were the project managers [....] We negotiated some fees from them, and they helped us to support the Vimy Foundation and incorporate their ideas as much as would be possible within Government of Canada guidelines." ${ }^{\text {46 }}$

\footnotetext{
${ }^{45}$ Steve Harris, interview by Breanna Lester, August 1, 2019.

${ }^{46}$ Christina Gaudet, interview by Breanna Lester, January 22, 2020.
} 
Executive Director of the Vimy Foundation, Caitlin Bailey also commented on their partnership:

The partnership for the education centre was a fairly unprecedented partnership for VAC. They do have private partners on the Veteran's awareness and wellness side of their mandate, but this was one of the larger [partnerships]. They have a Community Partnership Program where they partner on smaller projects, but this was a fairly new thing to partner with a private entity that was contributing so much funding towards the construction of this education centre. ${ }^{47}$

Though VAC's partnership with the Vimy Foundation was relatively extraordinary if only because of the amount of money invested [ $\$ 5$ million], collaborating with external organizations is not out of the ordinary for VAC. Robert Löken explained:

Some of the partners would be ... the obvious ones would be other government departments Canadian Armed Forces, Canadian Heritage, National Capital Commission, but when we look at other organizations, there's the Royal Canadian Legion, different associations for the regiments, so the Royal Newfoundland Regiment, all these regiments, there's all these associations: the Army, Navy, Airforce veterans ... there's a fair number of organizations, and then there's also some private organizations as well, so the World of Hockey: the Junior Hockey, the Memorial Cup [....] The museums across the country: Who's doing things and how do we work together? Military cemeteries: here [in Ottawa] there is Beechwood National Cemetery. So, it's really about looking at who are the partners out there that are looking for ... and in some cases, we may connect with partners who weren't planning anything, we kind of plant the seed when we connect with them and then as a group, we are able to have a broader impact than if we were just doing it on our own. ${ }^{48}$

So, while VAC is mandated as the governing body of commemorative work, there are many other organizations involved in actualizing their goals. However, as the above example of the Vimy Foundation's partnership suggests, even though they are external partners, their vision must also conform to Government of Canada mandates and protocols, thus limiting what is possible. As I explained earlier, each partnership VAC forms on any given project is also part of that project's assemblage.

${ }^{47}$ Caitlin Bailey, interview by Breanna Lester, July 24, 2019.

${ }^{48}$ Robert Löken, interview by Breanna Lester, November 20, 2019. 
The practical considerations discussed in this section are by no means the only factors VAC planners had to consider while planning for the centenary. And yet, when considered through the conceptual framework of this dissertation, they reveal burgeoning and unstable assemblages, assemblages that would be difficult for a relatively small team of workers to grapple with. And, though most of this was completed prior to the commencement of the events, planners still had to execute their plans and account for more logistics a result.

\section{The Execution Phase, 2014-2018}

On its own the First World War centenary planning was arduous work, but as Christina Gaudet reminded me, all this centenary planning was on top of their regular 5year commemorative planning cycle. Recalling that initial meeting in 2010, she lamented: "2014 wasn't that far away, but we were still dealing with our five-year cycle and our regular stuff that we barely had enough people to cover and get through." ${ }^{49}$ Because of this, a new team had to be built to accommodate the logistical needs of the centenary, during the centenary. Sylvie Thibodeau-Sealy joined the Commemoration Division at VAC in January 2017. She recounted: "When I first got in, there wasn't even a team. There was a management team, but they didn't have any supporting staff and we were three months out of an international event [.... I had six to seven people reporting to me $[\ldots]$ and they all had their own individual teams [.... I think it was 160 people all together." ${ }^{50}$ This reflects what Steve Harris referred to as working on a "surge capacity," meaning there is a small standing team who work on the five-year cycle and leading up to

${ }^{49}$ Christina Gaudet, interview by Breanna Lester, January 22, 2020.

${ }^{50}$ Sylvie Thibodeau-Sealy, interview by Breanna Lester, December 10, 2019. 
a large event, more team members are added. ${ }^{51}$ However, as Gaudet also commented, the requirements for said team have changed over the years:

Back in the earlier days, we had more veterans too. Ceremonies do change when there are living veterans versus not. fifteen years ago, there were hundreds of veterans that were able to go [....] The skills on the team have had to change, so we have less people focused on looking after veterans, and more people tasked with coping with public interest and the inquiries and making sure the access is being communicated, if you need a ticket to attend for security reasons and all of that. So, it really has been a change in the team and how we build a team and then what the focus is. ${ }^{52}$

The team is important. For example, because Robert Löken stepped into his role just as the commemoration at Vimy was ending, he was, "somewhat spoiled in having a team that is very well-established and know what they're doing.. ${ }^{93}$ Löken's language makes it seem like having a "well-established" team is an anomaly in this line of work, and given Harris, Gaudet, and Thibodeau-Sealy's previous comments, it appears so. The above comments from my interviewees suggest that, for a large-scale event like the First World War centenary, teams had to form quickly, and team members had to learn as they went. And, as Christina Gaudet also suggested, not everyone on their teams had a background in commemorations. She said, "2017 was exceptional and we had to grow a big team really fast, and people who didn't have a background in commemoration never mind some events we were asking them to do and travelling all the time, and it was exciting, and it was hard and stressful." 54 Though I discuss the stress of planning the centenary events in greater detail in Chapter Five, Gaudet's comment further assists in an understanding of the working conditions that underpinned the centenary planning and

\footnotetext{
${ }^{51}$ Steve Harris, interview by Breanna Lester, August 1, 2019.

52 Christina Gaudet, interview by Breanna Lester, January 22, 2020.

${ }^{53}$ Robert Löken, interview by Breanna Lester, November 20, 2019.

${ }^{54}$ Christina Gaudet, interview by Breanna Lester, January 22, 2020.
} 
suggests that VAC did not have the personnel resources they required to handle every logistical component.

At VAC, each commemorative event is its own "file." As Thibodeau-Sealy stated, "Whenever there's a huge event $[\ldots]$ it is the priority and the focus. If the rest of the department and you are approached about Vimy, drop everything and do that. It works for a little while, but it does get old quickly because the file that you're working on may not be the top priority of the department and it might not be the red-hot file of the day." ${ }^{55}$ And sometimes, you are working on several files at once. For example, Thibodeau-Sealy was working on Dieppe 75 while she was on site for the Vimy centenary. ${ }^{56}$ Though each file denoted a commemorative event, as I illustrated above, each file also included a separate set of stakeholders, partners, and challenges, and therefore a different assemblage. In Thibodeau-Sealy's case, she was working on Vimy 100 concurrently with Dieppe 75 , meaning she was also managing their assemblages concurrently as well.

Given all the moving parts, management is a key component of commemorative work. In our interview, Christina Gaudet mentioned that a lot of planning an event is "managing the flow of information and requests and changes" through email. ${ }^{57}$ Sylvie Thibodeau-Sealy mentioned one of the most difficult aspects of her role was managing the relationships of her team. She found herself stuck between two conflicting senior managers, one a male former Chief-of-Defence Staff hired specifically to assist with Vimy 100 who worked out of Ottawa, and the other a woman in Charlottetown. Thibodeau-Sealy described being stuck,

\footnotetext{
55 Sylvie Thibodeau-Sealy, interview by Breanna Lester, December 10, 2019.

56 Sylvie Thibodeau-Sealy, interview by Breanna Lester, December 10, 2019.

${ }^{57}$ Christina Gaudet, interview by Breanna Lester, January 22, 2020.
} 
between the two $[\ldots .$.$] They were polite in each other's company, but there were$ obviously some tensions there, and given that I was three months out to a huge international event, my hardest days were me trying to manage those relationships ... relationships of people who really should have put egos and resources aside knowing that this is a departmental and Government of Canada priority, and I felt like I needed to put that forth to them often. ${ }^{58}$

Indeed, veteran commemoration planner Christina Gaudet reinforced Thibodeau-Sealy's perspective in our interview. She recalled: "Just the culture between DND and VAC is very different and that was a very challenging leadership style to all of a sudden be thrust into and have to get used to. There was a lot of growing pains and a lot of stress just by the virtue of culture clash." ${ }^{\prime 59}$ Managing interpersonal relationships is not part of the established scholarly definitions of commemoration nor have scholars invested much time in appreciating such things at the bureaucratic level, and yet to Thibodeau-Sealy and Gaudet, it is integral to the success of their events. In this way, part of commemoration is the labour of managing human relations and in doing so, establishing team cohesion.

As my interviewees also made clear, travel associated with the planning of the centenary was frequent. Peter Mills discussed what it was like on those overseas trips:

There was also a lot of travel back and forth between France and Belgium and Canada and the expectation, given the cost of that, is you arrive in theatre (country), there is no day or two to get acclimatized to time change and to get ready. You arrive, you work the day, you travel the night, you're doing some prep for when you get there, and when you arrive, you hit the ground running and work another day, so there were a lot of days where I worked twenty-four to twenty-six hours straight when I would arrive in Europe. There're no catch-up days, so then the next day would be another long day, and then another long day until you then get on a plane on the weekend and fly back and then start all over again in Canada. ${ }^{60}$

Sylvie Thibodeau-Sealy had a similar experience. She recalled:

\footnotetext{
${ }^{58}$ Sylvie Thibodeau-Sealy, interview by Breanna Lester, December 10, 2019.

${ }^{59}$ Christina Gaudet, interview by Breanna Lester, January 22, 2020.

${ }^{60}$ Peter Mills, interview by Breanna Lester, November 20, 2019.
} 
[I went] overseas once a month for a week to two weeks [...] when you're there, you have a very short amount of time to put on an event that's going to be shown internationally. As soon as you hit the ground, you have to maximize your time, so you're going to work. Whether there is a time difference, it doesn't matter. As soon as you hit the ground, there is a schedule. We were only checking into the hotel at the end of the day because the first thing we're doing is meeting with the Embassy. ${ }^{61}$

Travel added a level of complex, difficult, and tiring work to the already-intense process. Christina Gaudet also described her experience. She said, "For the 2017 cycle, I was away in Europe for a week or ten days minimum every month from October [2016] ... then I was away for twenty-seven days for the delivery of the event [Vimy 100], and get home after this exhausting four hours of sleep over four days, then I was home for less time than I had been away for to deliver Vimy before I was packing my suitcase again to go back to deliver a reçu [recital, ceremony] for Passchendaele." ${ }^{2}$ These accounts reveal incredible work expectations and conditions that drain and cause stress to workers (more on this in Chapter Five). These comments also provide a rare glimpse into the everyday of commemorative planning up to the actual execution of the event that has yet to be considered by commemoration scholars as part of what commemoration is.

Once the day (or days) of the event arrive, it is a hectic rush to ensure the event is successful. As will be discussed more fully in Chapter Five, these days are often stressful and emotional, but for many of these VAC employees, they are also career-defining. Discussing Vimy 100, Christina Gaudet mentioned, “On Friday morning, we got up at six o'clock in the morning, we delivered our sound and light show that night, the next day was the sunrise ceremony, so we were literally at Vimy at 3:30 a.m. scraping the frost off

${ }^{61}$ Sylvie Thibodeau-Sealy, interview by Breanna Lester, December 10, 2019.

${ }^{62}$ Christina Gaudet, interview by Breanna Lester, January 22, 2020. 
the window of my golf cart which had the firewood on it to take over." ${ }^{63}$ Most of the VAC employees I spoke with discussed how challenging the actual days of the ceremonies were and, as will be discussed in the next chapter, there were several difficult aspects of the ceremonies that resulted in an abundance of criticism from the media and other passionate third parties. When things fail, it becomes the responsibility of VAC staff on site to attempt to fix them. Sylvie Thibodeau-Sealy touched on one of the major pitfalls of the Vimy 100 ceremony. She explained,

The sound quality wasn't so great. Some of the power had to be diverted more towards the sound which meant the power then was lessened on the toilets which means when you flush, there was less power for the water to flow, so it backed up. There was a lot of people that had to clean that which is nobody's job description. ${ }^{64}$

There is much more to this story that will be unpacked in the subsequent chapter; however, Thibodeau-Sealy's words exhibit an incredibly important aspect of commemorative work: ensuring the logistics are under control and contingency plans are in place in case crucial components fail.

\section{Post-Mortems}

When a commemorative ceremony ends, the file is not closed until a thorough post-mortem of the ceremony and its planning is conducted, and recommendations are made for future events. Though this process looks different depending on who is running it, both Robert Löken and Sylvie Thibodeau-Sealy provided me with a good understanding of what a "post-mortem" looked like after a First World War commemoration event like Vimy 100. Löken shared that "Each department does their

${ }^{63}$ Christina Gaudet, interview by Breanna Lester, January 22, 2020.

${ }^{64}$ Sylvie Thibodeau-Sealy, interview by Breanna Lester, December 10, 2019. 
own approach, and I do that with my team. Every event that we do, we will have a postmortem $[\ldots .$.$] There are notes and we hang on to those things so if we do another event$ like that one, it's a lessons-learned approach." ${ }^{\text {"65 }}$ Thibodeau-Sealy detailed her "postmortem" process as follows:

There's a couple of things we did. I made a point of individually and collectively thanking all the staff. I think they needed to hear that because a lot of them came back affected in different ways [....] I thanked them and let them just vent. They really needed to talk about their experience. That's part of the post-mortem of it all was letting people tell their account of it, and if it took twenty minutes that's fine, but if it took the hour, I took the hour and listened to them, and I think that helped a lot of people. That's the informal part of it. I personally think that sometimes it is more important than the formal part of briefing-up. It's letting people just come down from that experience because were on such a high for such a long time and didn't have time to digest all of it. That personal touch goes further. From a more formal point-of-view, as a Management Team, we did collect comments and put together a formal document that was presented to the Minister's Office and our Deputy in terms of what went well, what could have gone better, and how we would do something like this ... what we would recommend for the next one. That was well-received. ${ }^{66}$

From Thibodeau-Sealy's description, the debrief is an important and integral part of her role that serves as an official record for future commemorative activities, and allows her staff to decompress after a stressful work experience. This structure is important for professional cohesion because the complications that caused the experiences at the event elicited many emotions, and this is something we will return to in later chapters.

Thibodeau-Sealy also mentioned an external administrative audit that occurred after Vimy 100 and is also part of the post-mortem process. She explained,

The file was eventually audited, and the Internal Audit Evaluation reviewed it and I think that is also part of the post-mortem in terms of ... they are looking at it from an objective ... they weren't there ... it's kind of refreshing when you put your hands on it because they have a more objective point-of-view. They interviewed people and took a lot of notes and they said "OK- well you know, for a large commemorative event, we would say Vimy went well and this is

${ }^{65}$ Robert Löken, interview by Breanna Lester, November 20, 2019.

${ }^{66}$ Sylvie Thibodeau-Sealy, interview by Breanna Lester, December 10, 2019. 
why. From a process point-of-view, this is how we could improve some of these things." Those recommendations become part of the implementation for future overseas or Canadian events. ${ }^{67}$

Indeed, there is evidence to suggest planning has already begun for future

commemorations. Thibodeau-Sealy stated, "I know there is work being done now in terms of a ten-year plan of: How do we commemorate 10 years from now? And, what would that look like?"68

There were several lessons that came out of the centenary of the First World War, and some of them were even implemented for other events that occurred alongside.

Reflecting on the centenary events at Vimy, Peter Mills stated:

We did - I think - given the situation we are working with in terms of the environment (physical and political) deliver something quite extraordinary on April 9th. Was it without issue? No, but is there any major public event ... you want to think spectacles ...that goes without a hitch in that kind of environment? Probably not, and the key is really that we learn from it and try to improve for the next time. When the next time will be for Vimy, I don't know. We always go through a rigorous post-event analysis to determine what went well and what didn't and to try within our power to takes steps to mitigate those issues for the next time. We certainly learned a lot at Vimy that we applied to Passchendaele. ${ }^{69}$

Mills' comments encapsulate many themes of this chapter, and the dissertation as a whole. Though I detail the specific issues he references in the next chapter, he mentioned that Vimy 100 was an event, a "spectacle" that, though it was not perfect, underwent a post-mortem that proved useful for their next large-scale event at Passchendaele even though Passchendaele was (as previous chapters have indicated) a smaller affair. He was proud of the events, but also recognized that creating a flawless commemoration is impossible given what I recognize as commemorative assemblages, but also the working

\footnotetext{
${ }^{67}$ Sylvie Thibodeau-Sealy, interview by Breanna Lester, December 10, 2019.

${ }^{68}$ Ibid.

${ }^{69}$ Peter Mills, interview by Breanna Lester, November 20, 2019.
} 
conditions they had to navigate while planning and executing the events (elaborated on in Chapter Five). Nonetheless, what VAC accomplished at Vimy in 2017 seemed difficult given the unpredictable landscape and bureaucratic assemblages they were working with.

Much of this chapter has thus far focused almost exclusively on VAC's role in commemorating the centenary as the mandating governing body. However, there are many organizations outside of government that also planned commemorative events for the centenary, and it is important to appreciate their efforts as elements of the bureaucratic assemblages analysed in this chapter.

\section{The Work of Commemorative Stakeholders}

There is a whole industry of First World War commemorative work conducted by private sector and community-led establishments, some of which received funding through VAC's various funding platforms such as the Commemoration Partnership Program. Accordingly, this section analyses the labours of three commemorative bodies that worked, and are still working, tangential to VAC and the Government of Canada: The World Remembers; battlefield tour operators (specifically, Liberation Tours, Canadian Battlefields Foundation, and Fields of Fire Tours); and the Vimy Foundation. ${ }^{70}$

R.H. Thomson's light installations, The World Remembers, was a recipient of Commemoration Partnership Programme funding and it is a project that has had an ongoing, if uneven relationship with VAC. Thomson's installations showcase the names of

\footnotetext{
${ }^{70}$ According to VAC's website, the Commemorative Partnership Program (CPP) "expands the reach of VAC's remembrance programming by providing funding through activities that recognize all Canadian Veterans and Canadians who died in service [...] [and] the restoration of existing cenotaphs/monuments." Government of Canada, "Commemorative Partnership Program," https://www.canada.ca/en/news/archive/2014/05/commemorative-partnership-program.html.
} 
all war dead from the First World War in public spaces in digital form, unseparated by which side of the war they fought on. Thomson explained the process to me as follows:

We had to start small. We had to show the names, you had to tell people when the names would appear, so each family needed to know when their relative would appear, so each of the names would have to be timed to a minute. So, we created the insides of this which is this thing that goes on for twelve hours a day or night. It is absent of flag, it is absent of colour; colour has a connotation, flag has a connotation, an image is a connotation. Because it's Canada, there is a Canadian name in the centre. The names on the outsides change every twentytwo seconds, but the Canadian name waits for the next Canadian name. Every fifteen minutes, we go to a photograph. [....] We also streamed it online. In 2018, we had 108 locations in Canada, US, and EU all showing the same displays. ${ }^{71}$

When asked about the labour involved in actualizing a project on this scale, he reported:

I have five part-time people working for me. I have designers, data cleaners, coordinators. I can only hire them part-time because I get funding year by year. It's a lot of work [....] Before I went international in 2011, I had to know it would work. I went to three computer engineers in 2011 [with the concept] [...] and they came up with a set of algorithms that mean you can take any number of names and work them in the algorithms, and they would say "here is the order" [.... The Americans don't have a World War I database. They sent us thirtyeight Excel sheets. They were a mess. ${ }^{72}$

Thomson's project occupies an intriguing grey area between the national and international; the work is conducted largely in Canada for Canadians, by a Canadian, but there is also a recognition that the First World War was an international event and ought to be commemorated as such. Much like the VAC planners who ensured their commemorative events did not clash with other nations, Thomson found himself navigating the complicated nature of international cooperation. Also, like VAC's efforts, Thomson's commemorative project was a product of extensive human labour, such as extracting data from spreadsheets, that was not as glamourous as the finished product.

${ }^{71}$ R. H. Thomson, interview by Breanna Lester, September 16, 2019.

${ }^{72}$ Ibid. 
Thomson's project intersects with the VAC assemblages in several ways. First, as mentioned above, he was the recipient of Commemorative Partnership Program funding. He also provided insight into his relationship with VAC in our interview. He said: "They helped the project. They've understood it, they haven't put up a lot of bureaucratic resistance, and they've been there when I needed. Right now, I am going to them for new data because the data I have right now is from 2008 and I know that stuff has been corrected and amended so we have to update our data." 73 The "bureaucratic resistance" he mentioned was partially in reference to VAC's mandates. As a recipient of VAC funding, his project had to conform to its requirements: "The project must commemorate the achievements and sacrifices of those who served Canada since Confederation," have a finite duration, and "engage youth, Veterans, Canadian Armed Forces members and/or the general public in recognizing all those who served in Canada's efforts during war, military conflict or peace." ${ }^{\prime 4}$ This last stipulation echoes VAC's centenary mandates discussed earlier in this chapter.

The World Remembers is also discussed in the ATIP material. To aid in Thomson's goal of attracting participants from other countries, former Minister of Veterans Affairs Steven Blaney's team drafted a letter to send to foreign ministers. These ideas were developed through a series of email correspondence between Peter Mills and Christina Gaudet in January 2013..$^{75}$ There is also evidence in the ATIP material that Thomson himself met with Minister Blaney's team and other VAC team members to

\footnotetext{
${ }^{73}$ R. H. Thomson, interview by Breanna Lester, September 16, 2019.

${ }^{74}$ For a full list of eligibility requirements, visit: https://www.veterans.gc.ca/eng/remembrance/commemorative-events/commemorativepartnership/engagement/guidelines

${ }^{75}$ ATIP, Robert H. Thomson, “Draft Letter Regarding The World Remembers," January 10, 2013.
} 
discuss the progress of the project. In an email dated January 31, 2013, Peter Mills attached an email from a redacted party communicating sentiments that meetings with the Prime Minister's Office to brief it on the status of the project occurred that day. ${ }^{76}$ Further evidence provided by VAC in the form of a slide deck from what is commonly referred in government circles to be a 'Four Corners meeting' titled "The Road to 2017 - Four Corners Meeting" held on July 15, 2014 suggests the announcement of funding on August 4, during the Civic Holiday long weekend, of The World Remembers project. ${ }^{77}$ There is also evidence in the ATIP returns that The World Remembers was recommended to receive $\$ 259000$ from VAC's Community Engagement Partnership Fund..$^{78}$ Though overall it does not seem like a significant amount of professional labour was expended on The World Remembers on VAC's end, it was (and continues to be) a massive undertaking for Thomson.

A project such as The World Remembers requires the collaboration of many different parties. On one of the last pages of the look book for the project, Thomson extends gratitude to "the support of generous Canadians, private foundations, the Government of Canada, and [...] contributions from participating nations." He then lists several organizations from both Canada and elsewhere that contributed to the project. An adjacent page also acknowledges the ongoing partnership between The World Remembers and the Canadian War Museum. ${ }^{79}$ As this project shows, large commemorative undertakings are often not planned, funded, and executed by one person or organization

\footnotetext{
${ }^{76}$ ATIP, Peter Mills, email to Christina Gaudet and Robert H. Thomson, January 31, 2013.

${ }^{77}$ A "Four Corners meeting" is a meeting attended by the central agencies of government which could include the Prime Minister's Office or the Treasury Board. These meetings are incredibly important in government. ATIP, Veterans Affairs Canada, "The Road to 2017 - Four Corners Meeting," July 15, 2014. ${ }^{78}$ ATIP, Veterans Affairs Canada, "Community Engagement Partnership Fund - The World Remembers, 1914-1918," January 29, 2016.

${ }^{79}$ The World Remembers, “The World Remembers 1914-1918,” March 2019.
} 
and often require the assistance of others to bring to fruition. And, as a multi-faceted project involving spreadsheets, consultations with data professionals, and international governments, Thomson's commemorative project is also a commemorative assemblage that intersects with VAC's assemblages and those of the other stakeholders Thomson mentioned in his acknowledgements.

There is also a thriving battlefield tour industry operating out of Canada and with headquarters internationally. For this project, I interviewed representatives from three such groups, John Cannon and Phil Craig from Liberation Tours, Jérémie LeBlanc from Canadian Battlefields Foundation, and David Patterson, former board member and tour guide for Canadian Battlefields Foundation and proprietor of his own company, Fields of Fire Tours. These tour companies operate independent of VAC, and yet engage in similar kinds of labours as the VAC public servants, and as discussed more fully in the next chapter, are often affected by the commemorative decisions VAC makes. ${ }^{80}$

Museum professionals, battlefield enthusiasts, and long-time friends, John Cannon and Phil Craig grew their battlefield tour company, Liberation Tours, out of interest gathered from visitors to their modest military history museum in Keswick, Ontario. In 2006, Cannon, Craig, and a member of staff travelled to France and took the Juno Beach tour. It was on that tour, Craig said, that Liberation Tours was born. At the start, Cannon and Craig would meet five to six groups in France and convoy from spot to

\footnotetext{
${ }^{80}$ Though my interview with LeBlanc proved informative in other ways, namely in connecting me to David Patterson, I chose not to discuss the labour of that company here because it operates through the Wilfrid Laurier University Centre for Military and Disarmament Studies, did not work with VAC, and is therefore outside the scope of this project.
} 
spot, and finally there became a time when interest grew so much that their convoy method was not enough to accommodate everyone. ${ }^{81}$

Commenting on the current state of the battlefield tour industry, Cannon stated that “There isn't a lot of people doing it. We've been doing it so well that we've raised the profile a lot so there are a lot of other people doing it that weren't doing it before." ${ }^{\prime 2}$ Indeed, Craig shared that he and Cannon spent five years studying and rehearsing before leading their own tours, which often included reading the history, and actually visiting everywhere they intended to take participants. They were also adamant that they do no more than four tours a year to preserve the quality of each experience. It was clear to me that these two strive for a quality experience for each customer ${ }^{83}$ The work that Craig and Cannon put into their tours is reminiscent of the kinds of history workers Amy Tyson studied in The Wages of History; Craig and Cannon invest years of their lives in pursuit of flawless and memorable tours.

Logistically, John Cannon and Phil Craig advised that planning for these tours involves knowing your audience; their clientele are about sixty-three years old on average. Cannon explained:

It's all about not leaving too early in the morning because most of the people are retirees (our average age is sixty-three). You've got to feed them on time for lunch. You have to make sure they have a washroom to get to, and you have to get them back to the hotel by five because everybody has their routine. So truly, each day is planned around lunch on time and back to the hotel by dinner, and with that, what can we do in a day? So, high schools are different because you can drag them around all day and let them go, but not when people are paying many thousands of dollars and usually well-travelled and want a structured day. So, that structure says we can do one or two things in the morning, lunch (either organized or on their own), one or two things in the afternoon and back to the hotel, and from there, Phil and I will sit and plot all the places we think we need

${ }^{81}$ John Cannon and Phil Craig, interview by Breanna Lester, August 13, 2019.

${ }^{82} \mathrm{Ibid}$.

${ }^{83} \mathrm{Ibid}$. 
to go and it's usually two or three times as many places as can be done in a tour, and we decide what the most critical is and we pare it down until we have the most essentials for fifteen to sixteen days. That process takes six months to a year depending. ${ }^{84}$

Cannon suggests here that where they go is built around the amenities, a point that echoes an argument made earlier in Chapter Two about our scholarly need to think of commemorative landscape assemblages including such non-historical things such as toilets and restaurants. Craig added: "Basically, we are trying to get everywhere the Canadian Army went during the War and we have choices to make because if we have veterans or children of veterans, that's when we differ from the usual routine because there is a personal history attached to that." ${ }^{85}$ Herein lies a pillar of their marketing strategy; Liberation Tours aims to personalize each experience as much as possible, even down to the food choices of the guests. One of their goals is to accommodate the gastronomy of the tourists who would eventually visit them, though food is often difficult to find unless you bring your own or, in the case battlefield tour companies like Liberation Tours, know where to look. This means that, though they try to follow a standard tour schedule, such as those outlined in Chapter Two, their assemblage changes depending on who happens to be on their tour. The above comments also illuminate the labour that goes into the logistical planning of assembling a battlefield tour; there are many banal considerations that must be taken into account to ensure their patron's commemorative experiences are exceptional. In this way, the battlefield tour operators' work is similar to VAC's; both are responsible for ensuring the well-being of commemorators.

\footnotetext{
84 Ibid.

${ }^{85}$ John Cannon and Phil Craig, interview by Breanna Lester, August 13, 2019.
} 
Other notable labours discussed in our lengthy phone conversation confirmed the detailed logistics of booking hotels for 35 to 45 guests. Cannon clarified: "You need hotels that have twin bed options in case sisters or uncle and nephews are coming. We need a certain size. Smaller hotels would be too nervous to take on a group that fills all their rooms. It's tricky. We work with the larger business hotels." ${ }^{86}$ From an outsider's perspective, Cannon and Craig run an impressive business, made even more impressive knowing that they have yet to hire anyone else to assist them. They plan and conduct all tours on their own. Craig explained, "We make sure wherever we are going, we've been there personally before we go." ${ }^{\prime 87}$ They maintain that their tour company is a one-of-akind experience, and undoubtedly so, but there are always competitors.

In comparison, David Patterson's company Fields of Fire Tours accommodates a similar clientele to Liberation Tours, though they again offer a slightly different service to Cannon and Craig. Patterson offers personalized and smaller group tours in addition to the larger bus tours. ${ }^{88}$ Patterson's clientele is also similar to Liberation Tours, though he communicated that the majority of his participants are "younger retired people (people from fifty and up)." ${ }^{89}$ Comparable to Liberation Tours, it appears that Patterson plans and leads most of his company's tour by himself, meaning he must make quick decisions to make sure his clients receive the best possible experience. When asked whether he used bagged lunches on his tours (a concept Liberation Tours was not keen on), Patterson added:

Depends on the group. With a small group, no. With the big groups, yes because it's easier. [....] You budget your time accordingly. The challenge is that I've

\footnotetext{
${ }^{86} \mathrm{Ibid}$.

${ }^{87}$ Ibid.

${ }^{88}$ David Patterson, interview by Breanna Lester, September 3, 2019.

${ }^{89}$ Ibid.
} 
been there and know what I want to show you, but you as a client, you don't know what you're missing. Sometimes it's a compromise to finish lunch quicker to show you this thing that you don't know is cool, but I do because I've been there. Adjusting it to the pace of the group if you like. ${ }^{90}$

Considering the locations of toilets and spots for lunch are immensely important to these battlefield tour operators, but as Patterson indicated, he also likes to assemble a plan on the go. Like Cannon and Craig, Patterson also tries not to take his participants to places he has not experienced himself, meaning that he also conducts extensive fieldwork at the battlefield sites and scopes out toilet locations and restaurants. Though it is clear from their comments above, and in the rest of the dissertation, that these tour operators love what they do, it is also a great deal of work to conduct battlefield tours. And, as I discuss in the next two chapters, VAC and these battlefield tour companies have a fraught relationship.

The centenary seemed to increase the labours of battlefield tours, just as it was considered "exceptional" to VAC planners as well. ${ }^{91}$ John Cannon of Liberation Tours started experiencing an increase in "awareness" of battlefield tours "because of Canada coming out of Afghanistan and all of the big anniversaries that we are coming to an end with next year [referring to 2020]. All this converging made the last ten years an ideal time for battlefield touring to really become a more common thing." ${ }^{.92}$ His tour partner, Phil Craig added that the number of tours experienced an increase from one or two a year to up to four tours a year over the last ten years. ${ }^{93}$ Though this does not appear to be a dramatic increase, it is worth noting here that Cannon and Craig plan, administrate, and

\footnotetext{
${ }^{90}$ Ibid.

${ }^{91}$ Christina Gaudet, interview by Breanna Lester, January 22, 2020.

${ }^{92}$ John Cannon and Phil Craig, interview by Breanna Lester, August 13, 2019.

${ }^{93}$ Ibid.
} 
conduct these tours as a duo, meaning that at the height of the centenary period, they were running four commemorative tours on their own. Cannon also revealed in our interview that each of these tours takes approximately "six months to a year" to plan from beginning to end. ${ }^{94}$ At their peak, therefore, Cannon and Craig spent two to four years in total to plan for four trips. ${ }^{95}$ This is no small feat.

Though the Vimy Foundation was discussed earlier in this chapter, it is a nonprofit and as such run their own commemoration programming. Caitlin Bailey described her role at the Foundation to me as being "responsible for the strategic direction of the Foundation, so I'm responsible for helping the board arrive at a strategic vision and then executing that strategic vision for the organization which includes working with the staff to create or change our programming to reflect our current vision." ${ }^{96}$ Though her foundation has educational initiatives year-round, Bailey asserted that, "We all live for two days a year: November 11 and April 9, and all of our labours lead up to those two dates in terms of commemorative activities. Education for us goes all year round and we are always running education programs and working with youths all the time, but in terms of when we are performing our big activities, it is November and April." ${ }^{\prime 97}$ Bailey's comments further illuminate the commemorative calendar I mentioned earlier that is shared by both VAC planners and stakeholders like the Vimy Foundation. In reference to the realisation of the Vimy education centre, Bailey stated that "The Foundation was not involved in the construction of the education centre, nor do we manage it, but certainly during the fundraising time, it was face-to-face meetings, lots of emails, lots of calls, a lot

\footnotetext{
${ }^{94} \mathrm{Ibid}$.

${ }^{95} \mathrm{Ibid}$.

${ }^{96}$ Caitlin Bailey, interview by Breanna Lester, July 24, 2019.

${ }^{97}$ Ibid.
} 
of dealing with upper-level public servants at VAC who are responsible for the running of these projects. ${ }^{98}$ In her comment, Bailey provided insight into the kinds of labour her staff experienced during the centenary. The material things she listed also reveal the bureaucratic processes involved in assembling the education centre.

As was already discussed through the examination of the building of the Vimy education centre and Centennial Park in Chapter Two, VAC's bureaucratic assemblages often interacted with the assemblages of commemorative workers outside government. However, they have also been known to clash with these commemorative workers for reasons that will be discussed in the next two chapters. Nonetheless, examining the commemorative work that occurs on the periphery of government broadens the number of commemorative assemblages that can intersect, but also complicate VAC's bureaucratic processes.

\section{Conclusion}

Many historians view commemoration as an "act of remembrance" or a "practice" which effectively reduces it to a ceremonial concept that exists only in the moment in which the event occurs. This is supported by some commemorative traditions, including the wearing of poppies only between November 1 and 11, and the broadcasting of a seemingly pristine ceremony on television. However, as this chapter has shown, commemoration is much more than an anniversary event. Commemorative events can require years of pre-planning conducted by individuals neither the public eye nor scholarly literature on commemoration capture.

${ }^{98}$ Ibid. 
As Peter Mills' comments that opened this chapter suggests, commemoration is more than an spiritualistic reinvigoration of identity, collective memory, and nationalism; it is often difficult logistical work the involves navigating mandates and protocols, preparing briefings, corresponding via email, managing human relationships, travelling overseas for weeks at a time, and collaborating with many national and international stakeholders. As Mills stated, commemorative planning involves an initial planning stage where logistical planning is conducted ahead of the execution of the actual events, followed by a post-mortem process. At each stage of planning, there are more and more considerations that arise and must be dealt with if the event is to be successful.

These considerations are seldom discussed in current commemoration scholarship, perhaps because scholars who pursue answers to questions of commemoration look for them in the paper records of archival institutions, or, as Dominique Clément points out in his article on freedom of information in Canada, "most historians avoid using [ATIP]. ${ }^{\prime 99}$ However, the approximately 8000 pages I received were integral to enriching my understanding of what commemoration is beyond its surface. Still, using ATIP as a solitary archive proved limiting, if only because much of it contained redactions and lacked the emotional perspectives I was searching for. The interviews I conducted greatly assisted in this regard and allowed me to tap into the "backspace" of government beyond the official discourse readily available to the public. ${ }^{100}$ Together, the ATIP materials and interviews revealed a bureaucratic assemblage comprised of seemingly inactive material things such as briefing notes,

\footnotetext{
${ }^{99}$ Dominique Clément, “'Freedom' of information in Canada: Implications for Historical Research,” Labour 75 (2015): 74.

100 Jiwani and Krawchenko, "Public Policy, Access to Government, and Qualitative Research Practices," 62.
} 
emails, promotional material, and funding applications, but also interpersonal relationships, overseas travel, and stakeholders.

Accordingly, the first three sections of this chapter examined commemorations as bureaucratic work conducted via email, in briefings, in offices based (mostly) in Ottawa and Charlottetown as well as on the same battlefield landscapes discussed in Chapter Two. Much of what VAC workers do, though constrained by Government of Canada mandates and protocols, is consider practicalities during the initial planning stages so the execution stage runs as smooth as possible. These practical considerations are at the core of commemorations and do not receive the scholarly attention they deserve as it is the execution of these logistical considerations that determines whether an event is successful or not. The last section of this chapter focused on how commemoration professionals working outside government experience similar kinds of labour to the VAC public servants and interact with the VAC commemorative assemblages in different ways, whether in the capacity of stakeholder, funding recipient, or in the case of battlefield tour companies, operate based on VAC's instruction. A possible assemblage, captured in Figure 3.1, portrays a representation of what commemoration is beyond its current scholarly definition and includes the landscape-based assemblages discussed in the previous chapter.

As this chapter has ultimately shown, commemoration planning is about ensuring that those who attend the events are happy and secure through the managing of logistics; it is crucial that attendees have access to amenities such as adequate transportation, food, shelter, and shade, and that those at the helm have contingency plans in place in case something goes awry. Because - as the following chapter explains - there are 
consequences if not. Accordingly, to assist landscapes in the creation of affective commemorative experiences on minds and souls, the bodily needs of patrons must be met.

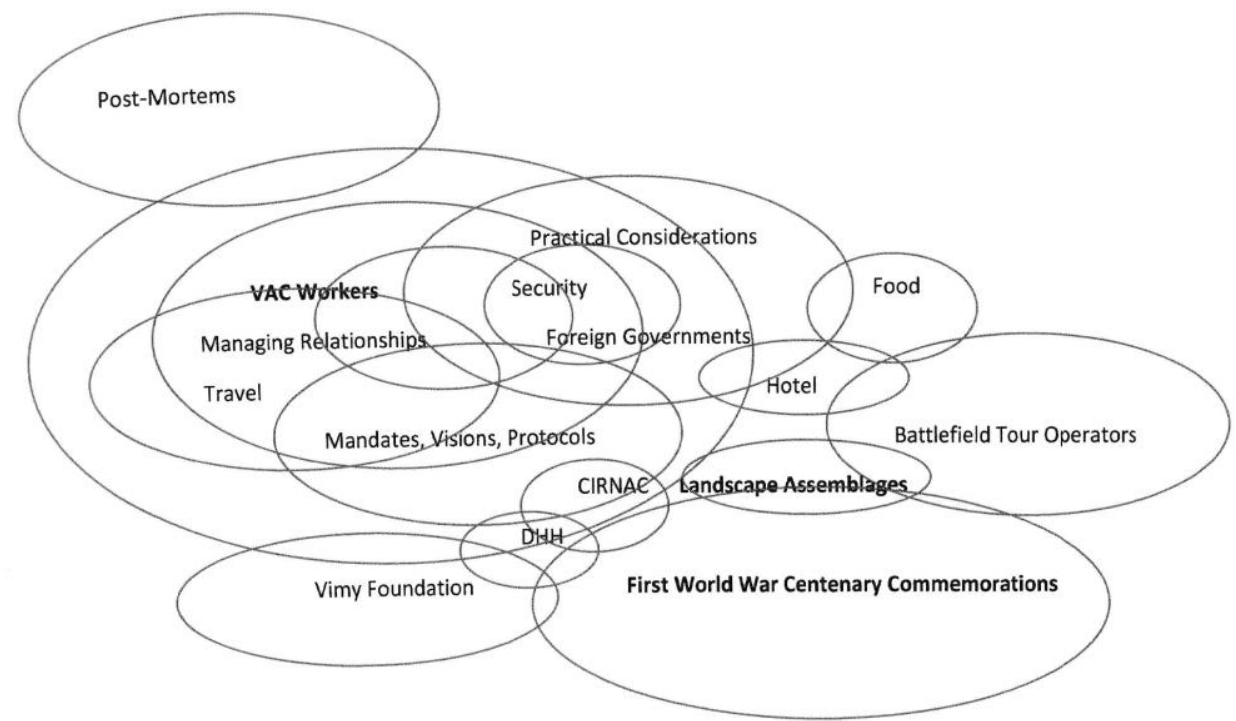

Figure 3.1 - Situational Map of the bureaucratic assemblage of the Government of Canada First World War centenary from the perspective of Veterans Affairs Canada. 


\section{Chapter Four: The Narratives of Commemorative Assemblages}

In the end, they are events and you really need to have iron-clad logistics to be able to function with these, otherwise your message [gets] completely lost because all people can focus on are the toilets. That is really a reality of running these. [If what] people focus on is inefficient crowd control, toilets, overflowing garbage, the actual act of commemoration gets lost.

-Caitlin Bailey, Executive Director, The Vimy Foundation ${ }^{1}$

\section{Introduction}

The assemblages discussed and visualised in the previous two chapters point to a complex of nonhuman actors, people, ideas, and logistical considerations. This chapter considers the role of metanarrative through an examination of the "Road to 2017" as a nexus of many assemblages, the First World War centenary among them. Using ATIP material and interviews, this chapter looks at how and why this metanarrative was part of, and ultimately complicated centenary planning. Specifically, this chapter examines how the mega-commemorative period the Government of Canada recognised as the "Road to 2017" muddled an already complicated First World War centenary assemblage. ${ }^{2}$

Accordingly, this chapter argues that though the Road to 2017 initiative made sense as an organizing method, its intended metanarrative regarding the invention of Canada around a series of militaristic events proved ineffective when some of the crucial logistical elements I described in the previous chapter failed to meet the expectations of its participants. And toilets, we shall see, played an unusually important role in all of this.

The Road to 2017 was a complex of commemorations, or, as Jean-Pierre Morin put it,

a series of commemorative events leading up to Canada 150 in 2017. As part of that, there were various commemorative events that were highlighted. The first

${ }^{1}$ Caitlin Bailey, interview by Breanna Lester, July 24, 2019.

${ }^{2}$ For the sake of readability, I will drop the quotation marks around Road to 2017. 
one was the War of 1812; the second major ones were the World War commemorations. The World War commemorations were packaged together, even though they were dealt with separately, and then for good measure, a commemoration of Afghanistan was thrown in just to make everyone's lives terrible and detract everyone from reality. ${ }^{3}$

Theoretically, then, the Road to 2017 started with the 1812 commemorations and should have ended with the seventy-fifth anniversary of the end of the Second World War in 2020. However, as Morin also pointed out in our interview, the Harper government actually conceived of the Road to 2017 as including the 2010 Vancouver Olympics. ${ }^{4}$ In the end, though, it started with 1812 bicentennial (2012) and culminated with Vimy 100 and Canada 150 in 2017.

The Vimy centennial event, which was known as Vimy 100, was integral to the Road to 2017 because of its commonly acknowledged status as a formative battle in the making of the Canadian nation. As prominent military historian Tim Cook put it, Vimy is "part of the fabric and fable of the nation [....] As Canada developed over time, we cast aside much that grounded us in the past; yet there are some ideas, myths, and icons that persistently carry the weight of nationhood. Vimy is one of them." Indeed, Morin posited that the entire purpose of the Road to 2017 was to solidify the familiar Vimy-asbirth-of-the-nation myth that has long been integral to a largely Anglo-Canadian national imagining of the battle. Morin continued:

The birth of the nation mythology was what the Harper government was trying to create with the Road to 2017. It was the argument that the countries, nations, peoples are forged through conflict, strife, and adversity because, as we all know, that is not the traditional national narrative; Canada is a country that came together because of consensus because there's relatively little conflict compared to France or the US or even Britain. So, he was adamant that that was part of it. He bought in fully to the Vimy myth and that was clear and that was the

\footnotetext{
${ }^{3}$ Jean-Pierre Morin, interview by Breanna Lester, July 5, 2019.

${ }^{4}$ Ibid.

${ }^{5}$ Tim Cook, Vimy: The Battle and the Legend (Toronto: Allen Lane, 2017), 3.
} 
direction that we had. For Harper, it starts with 1812 and it ends with Vimy Ridge because it makes the narrative complete. ${ }^{6}$

This direction was unfavourable to Morin. He thought it, "highly problematic to have a celebratory national anniversary of Confederation linked to the centennial commemorations because there is a lot that gets left out when you continue with this 'birth of a nation' idea." ${ }^{77}$ He was not alone in his frustrations.

The Vimy mythology was highly contested by scholars during the centennial, most prominently by historian Ian McKay, and his co-author Jamie Swift. In 2012, McKay and Swift published Warrior Nation which argued that Canada (under the Harper government) was in a process of rebranding, not as a country of peacekeepers, but as a country of warriors, evident in "newly minted Loonies with remembrance poppies on them [...] ; proliferating highways of heroes[...] ; a ramped up blood-and-soil cult of Vimy Ridge, including something called Vimy Week; a multi-million-dollar propaganda push aimed at flogging a cardboard version of history, painting the foolish, inconclusive War of 1812 in patriotic colours." ${ }^{8}$ In their pursuit of a "more complicated truth," McKay and Swift use government websites and media, juxtaposed with soldiers' letters, to reposition Canada as a nation of peacekeepers and, in doing so, reject any further perpetuation of the warrior mythology. ${ }^{9}$ Their next book, The Vimy Trap (2016) zeroed in on Vimy as the central myth in the warrior metanarrative they identified in Warrior Nation. In The Vimy Trap, McKay and Swift scrutinized prominent war historians as

\footnotetext{
${ }^{6}$ Jean-Pierre Morin, interview by Breanna Lester, July 5, 2019.

${ }^{7}$ Ibid.

${ }^{8}$ Ian McKay and Jamie Swift, Warrior Nation: Rebranding Canada in an Age of Anxiety (Toronto: Between the Lines, 2012), 9-10.

${ }^{9}$ McKay and Swift, Warrior Nation, 297.
} 
"Vimyists." 10 Among the "Vimyists," according to McKay and Swift, were popular historian Pierre Berton whose 1986 book, Vimy, helped to legitimize the battle as a national symbol for a large reading public, and television personality Don Cherry who, cupping a Legion Vimy 100 cap on an April 2014 Hockey Night in Canada, still then one of the most watched television events in Canada, called Vimy the "birth of a nation."11 In all, McKay and Swift accuse their perceived "Vimyists" of perpetuating a "narrow nationalism," and a "wilful refusal of the realities of twentieth century warfare."12

Tim Cook's centenary book, Vimy: The Battle and the Legend (2017) also traces the narrative of Vimy through time. ${ }^{13}$ In it, he acknowledges that the "Vimy idea is admittedly not universally accepted. Our heroes and legends are rarely all things to all people." Yet he also maintains that "the [First World War] was an important and transformative event for all." ${ }^{\prime 14}$ In 2017, Cook and McKay were able to share their differing views on an episode of TVO's popular public affairs program, The Agenda with Steve Paikin, titled "A Century After Vimy." In the roundtable discussion, McKay took every opportunity to oppose Cook's responses to Paikin's questions about Vimy's significance. Though Cook interrupted McKay on occasion, he largely remained

\footnotetext{
${ }^{10}$ Ian McKay and Jamie Swift, The Vimy Trap, Or How We Learned to Stop Worrying and Love the Great War, 9-11.

${ }^{11}$ Pierre Berton, Vimy (Toronto: McClelland Stewart, 1986) and Hockey Night in Canada, "HNIC Coach's Corner - April 5, 2014, https://www.youtube.com/watch?v=xWzFn29lqBo\&ab_channel=p00njabiHD.

${ }^{12}$ McKay and Swift, The Vimy Trap, 11.

${ }^{13}$ Arguably the most accomplished military historian of Canada, Tim Cook is the author of several books, including At the Sharp End: Canadians Fighting the Great War. 1914-1916 (Toronto: Viking Canada, 2007) and Shock Troops: Canadians Fighting the Great War1917-1918 (Toronto: Viking Canada, 2009). He was also among those labelled a "Vimyist" by McKay and Swift.

${ }^{14}$ Cook, Vimy, 5-6.
} 
diplomatic, despite McKay's accusations that Cook was, "putting a happy face on a holocaust." 15

While this scholarship and debate are vital in understanding how Vimy evolved as a metanarrative and has changed over time, it does not teach us much about how this metanarrative was translated into commemorative practices at Vimy 100 and why and how those practices were effective in communicating it. Working again from my archive of ATIP material and interviews with key planners, this chapter explores how metanarratives such as the Road to 2017 and Vimy-as-birth-of-the-nation impact commemorative planning and its planners. In doing so it offers a complementary, but also different perspective on Vimy 100 than appeared in the literature (and in the media).

\section{The Road to 2017, History, and Commemoration}

As explained in the previous chapter, VAC separated their commemorative mandate into three pillars: Awareness and Promotion; Events and Commemoration; and Lasting Legacy. Under each of these pillars were events that commemorated the War of 1812, First World War, Second World War, and "complementary" events such as the war in Afghanistan. Other "complementary" initiatives included: a "memorial route interpretive feature, a national monument to Canada's mission in Afghanistan, and a tribute to surviving Second World War veterans." ${ }^{.16}$ Each of these occasions were assemblages on their own; the Road to 2017 essentially created contact between them. A

${ }^{15}$ The Agenda with Steve Paikin. "A Century After Vimy,” TVO, April 12, 2017. https://www.youtube.com/watch?v=PTIOOssI_CU\&ab_channel=TheAgendawithStevePaikin.

${ }_{16}$ ATIP, Veterans Affairs Canada, "The Great Wars Legacy: Canada's Duty to Remember," August 27, 2013. 
draft proposal of objectives for the August 4, 2014 launch of the official Canadian First World War commemoration also makes the commemorative intention clear:

1) To pay tribute to the sacrifices made by Canadians in all conflicts including Afghanistan;

2) To instil a renewed sense of national pride in how the sacrifices of so many Canadians shaped the Canada we know today; and

3) To encourage Canadians to reconnect with their history and honour Canada's proud tradition of service. ${ }^{17}$

This list of commemorative objectives shows that the First World War centenary was not just about the First World War, especially not in its infancy under the Harper government. As Jean-Pierre Morin observed in our interview: "For the Harper government, it started with the Olympics [2010] and it ended with Canada 150 [July 1, 2017]." ${ }^{" 18}$ However, connecting the World Wars' commemorations to Afghanistan was the intention of Harper's government since at least the $90^{\text {th }}$ anniversary of the Battle of Vimy Ridge in 2007. Similarly, Tim Cook observed that "[t]he ceremony for a ninetyyear-old battle was set against Canada's military operations in Afghanistan [....] On April 9, 2007, there was no separating Vimy from Afghanistan."19

This metanarrative was also prominently and publicly displayed in stone on the National War Memorial in Ottawa. On November 11, 2014, the memorial was rededicated for a third time to include the dates of the South African War and the Afghanistan Mission. It was originally unveiled in 1939 to commemorate the service of those who fought in World War I and was re-dedicated in 1982 to include the Second World War and the Korean War. ${ }^{20}$ The inclusion of a war that pre-dated the original

\footnotetext{
${ }^{17}$ ATIP, Veterans Affairs Canada, "Proposal - World War Commemoration August 4th Launch Event."

${ }^{18}$ Jean-Pierre Morin, interview by Breanna Lester, July 5, 2019.

${ }^{19}$ Tim Cook, Vimy: The Battle and the Legend (Toronto: Penguin Random House, 2017), 361.

${ }^{20}$ Bruce Campion-Smith, "War memorial changes stir controversy," The Star, November 11, 2014, https://www.thestar.com/news/canada/2014/11/11/war_memorial_changes_stir_controversy.html.
} 
purpose of the memorial and a conflict that occurred some ninety years after its conclusion was seen by some stakeholders as problematic. For example, a November 2014 article from the Toronto Star highlighted some of the controversy surrounding the new additions. First, the article stated that the Royal Canadian Legion objected to the proposed change when it was consulted and argued against the singling out of specific conflicts. Furthermore, Legion spokesperson Bruce Poulin questioned what the criteria were for the addition of dates to the memorial and added that the inscription "In Service to Canada" (also added in 2014) should be sufficiently inclusive to all veterans. He further suggested that if awareness of Canada's conflicts was the aim of the inscribed dates, then erecting plaques around the memorial was a more palatable option. ${ }^{21}$ Despite objection on the part of the Royal Canadian Legion, the dates of five Canadian conflicts are still prominently displayed on the National War Memorial, clearly and publicly commemorating all in equal measure, and as part of a larger, unifying militaristic narrative.

As I discussed in the beginning of this chapter, the War of 1812 commemorations marked the beginning of the Road to 2017. As part of this commemorative moment, the Government of Canada (through VAC and Public Services and Procurement Canada (PSPC)) added a War of 1812 volume to the Books of Remembrance. These large tomes "commemorat[e] the lives of more than 118,000 Canadians who, since Confederation, have made the ultimate sacrifice while serving our country in uniform." 22 The anachronism that appears on the VAC website, that the books are meant to capture the

\footnotetext{
21 Ibid.

${ }^{22}$ Veterans Affairs Canada, "Books of Remembrance," Government of Canada, https://www.veterans.gc.ca/eng/remembrance/memorials/books.
} 
names of the fallen "since Confederation" and that the newest addition deals with a conflict that ended fifty years before Confederation, reflected the power of the Road to 2017 to affect commemorative decision making, an impact that outlasted the Harper government. Indeed, though commemorative plans shifted slightly when Trudeau's Liberals took office in Winter 2015, a December 17, 2018 article in The Star indicated that plans to add the 1812 Book were still underway, and in fact the book was formally unveiled in February 2019. ${ }^{23}$

But there were changes in First World War commemorative planning that followed the change in government. The 2015 election complicated commemorative planning and the centenary objectives shifted to accommodate the Liberal agenda emphasizing Liberal party mandates of youth, diversity and inclusion, environmental considerations, and Indigenous reconciliation. ${ }^{24}$ From Morin's perspective:

Initially, the Road to 2017 commemorations were all kind of part of a master plan, not that there was much direction in the master plan, but it was "here's the official list, here are the things we are going to commemorate, go commemorate them." After the fall of the Conservatives and the rise of the Liberals, that plan was basically ignored. Everything for Canada 150 was redone, but all of the First World War events that were after 2015 (like Vimy Ridge) were taken over by the Liberals $[\ldots .$.$] The tone of the commemorative events had to be adjusted$ to the new government, which is normal, but it also meant that all the little things that had been planned fell off the table to just concentrate on the main events, so if you look at the First World War commemorations, its just the highlights [....] [An emphasis on] Vimy was always the plan. It was always going to be centred around Vimy with much more emphasis on specific battles. The Battle of Ypres, Passchendaele, the Last 100 Days were supposed to be larger because the end of it was supposed to coincide with the Second World War commemorations. ${ }^{25}$

${ }^{23}$ Bruce Campion-Smith, ““'Books of names and a solemn ceremony honour Canada's war dead on Parliament Hill," The Star, December 17, 2018, https://www.thestar.com/news/canada/2018/12/17/booksof-names-and-a-solemn-ceremony-honour-canadas-war-dead-on-parliament-hill.html (accessed July 11, 2020). Veterans Affairs Canada, "Books of Remembrance," Government of Canada, https://www.veterans.gc.ca/eng/remembrance/memorials/books.

${ }^{24}$ Cindy Clegg, "Vimy 100 Vision," Cindy Clegg Communications, April 2016.

${ }^{25}$ Jean-Pierre Morin, interview by Breanna Lester, July 5, 2019. 
At the time of the election in October 2015, the First World War centenary had been underway for a year. Planners working on these files had to adapt and modify to accommodate the Trudeau government mandates; as indicated in the previous chapter, everything public servants planned had to adhere to their current government mandates and protocols. These changes, we shall see later in the chapter, contributed to some of the logistical problems that occurred during centenary events.

Though priorities were altered because of the 2015 election, aspects of the metanarrative endured, despite good advice from historians working within government, such as Steve Harris, Director at the Directorate of History and Heritage (DHH). In our interview, Harris communicated a difficulty in persuading federal commemorative planners to broaden the commemorative scope:

[The centennial has] been event-driven with the two focal points: Vimy and Beaumont-Hamel and it has been difficult to persuade government - not necessarily VAC - that there are other battles of probably greater significance than Vimy [....] VAC knows that full well, but it's because that monument exists; you can't get away from it. You can't go to one of the memorial plaques in Moreuil Wood or whatever and expect the same degree of enthusiasm on the part of Canadians who might want to go there because it isn't the monument and it isn't the tunnels. ${ }^{26}$

Harris' comments knit together observations of the two previous chapters; he was confined to his mandate, and the mandate was based off which landscapes were thought to be most affecting. In this case, Vimy was considered paramount. Harris' job was also to consult VAC on its verbiage, but ultimately, it was not his job to dictate how it performed their work.

Part of Harris' frustration stems from the inherent purpose of commemoration as a phenomenon not concerned with history, but rather with the maintenance of national

\footnotetext{
${ }^{26}$ Steve Harris, interview by Breanna Lester, August 1, 2019.
} 
identity and political agendas. As Harris put it, "you do what you can, and you know where you want to draw the line. Sometimes it works and sometimes it doesn't. Commemoration is not meant to teach. ${ }^{.27}$ Fellow historian-in-government JeanPierre Morin shared similar sentiments in our interview. When asked about the connection between Canada 150 and the centenary of the First World War, Morin stated:

I have many opinions about Canada 150 . Ultimately Canada 150 was not about history; it wasn't even about heritage. It wasn't about how we got here; it was about where we are going. So therefore, any references to history unless it was Indigenous and admitting our bad history towards Indigenous peoples, there was no history in Canada 150. Period [....] History is secondary when it comes to commemorations. Politics were more important than getting the history right. ${ }^{28}$

If commemorations are not about history, the anachronism was not a consideration for those who established mandates for the centenary. Nonetheless, despite their frustrations, public servants like Harris and Morin found it challenging to mitigate their professional knowledge of history and their jobs to facilitate the mandated metanarratives. Inevitably, as Harris put it, "It's hard to fight 102 years of historical interpretation." 29

So, what (if anything) was altered after the 2015 election? And, what were the circumstances under which the centenary continued? Once the Liberal government took over, VAC pivoted its mandates to greater emphasize youth inclusion and Indigenous reconciliation during the centenary commemorations. In reference to what he assisted in planning for Vimy's ninetieth anniversary in 2007, Harris explained:

It wasn't reenactors, it wasn't people saying lines, and VAC said (and this is part of their conundrum) "our audience is the youth because if we can't make the youth embrace the First World War and Second World War, when they are thirty or forty, they're not gonna come. So, we have to attract the youth and to attract the youth, we need to provide stuff which you didn't provide in 2007 because you were running kind of a military commemorative event, not a

\footnotetext{
${ }^{27}$ Ibid.

${ }^{28}$ Jean-Pierre Morin, interview by Breanna Lester, July 5, 2019.

${ }^{29}$ Steve Harris, interview by Breanna Lester, August 1, 2019.
} 
commemorative event that had a real focus on attracting youth." So, having people stand up and read letters home from somebody appeals to youth because of the individual, whereas a band playing "I'm Dreaming of Home" doesn't in the same way. ${ }^{30}$

Harris' comment is similar to Morin's earlier remark that Canada 150 (and the commemorations surrounding it) was not about history. He also highlighted an emphasis on engaging youth because they are the ones that will continue to attend commemorative events: more interest is key to the success of a commemorative event. To further comply with the Trudeau government's mandates, there was a shift to include more Indigenous programming than was present during the ninetieth anniversary of the First World War. Robert Löken recognized the shift to a more Indigenous-conscious programme. He commented:

We've noticed (and I've noticed) that in the past six to ten years, there's been a much stronger focus on Indigenous inclusion in ceremonies and events across the country, and that's really part of the Government's broader reach into the reconciliation. It's right. It's what we should be doing, but it's something that I think back even to when I was a teenager in Cadets and I remember parading for Remembrance Day and there was never any acknowledgement of Indigenous lands or there wasn't Indigenous components to events and ceremonies. Not saying that it's something that is very, very recent, but it is. It's only been in the last ten years that we're really putting an emphasis on acknowledging the Indigenous component. So, that gets added to the equation and whatever the ... and I don't want to make it sound flippant ... but whatever the flavour of the day for the Government is, there may be some shifts depending on what is the broader government direction. ${ }^{31}$

Löken's comment illustrates a normalcy in shifting mandates to accommodate the politics of the government in power. This is part of a public servant's job, but it also added additional components to the assemblages that were already forming under the previous government.

\footnotetext{
${ }^{30}$ Steve Harris, interview by Breanna Lester, August 1, 2019.

${ }^{31}$ Robert Löken, interview by Breanna Lester, November 20, 2019.
} 
Ultimately, all commemorations between 2012 and 2020 remained part of the Road to 2017 metanarrative. However, everything after Vimy 100 received less media attention, and less attention overall as I demonstrate in this chapter's subsequent pages. The visual promotional material for Passchendaele and Vimy also ensured a connection of these events to Canada 150, even though Passchendaele 100 occurred four months after Canada 150. As Figures 4.1 and 4.2 show, the Canada 150 logo was featured at the bottom of the posters for Vimy 100 and Passchendaele 100. And, despite the guidance of historians in government such as Steve Harris, the birth of the nation metanarrative around Vimy persisted. In his Vimy 100 speech on April 9, 2017, Prime Minister Justin Trudeau used the Vimy as birth of the nation rhetoric on four separate occasions in the span of six minutes. ${ }^{32}$
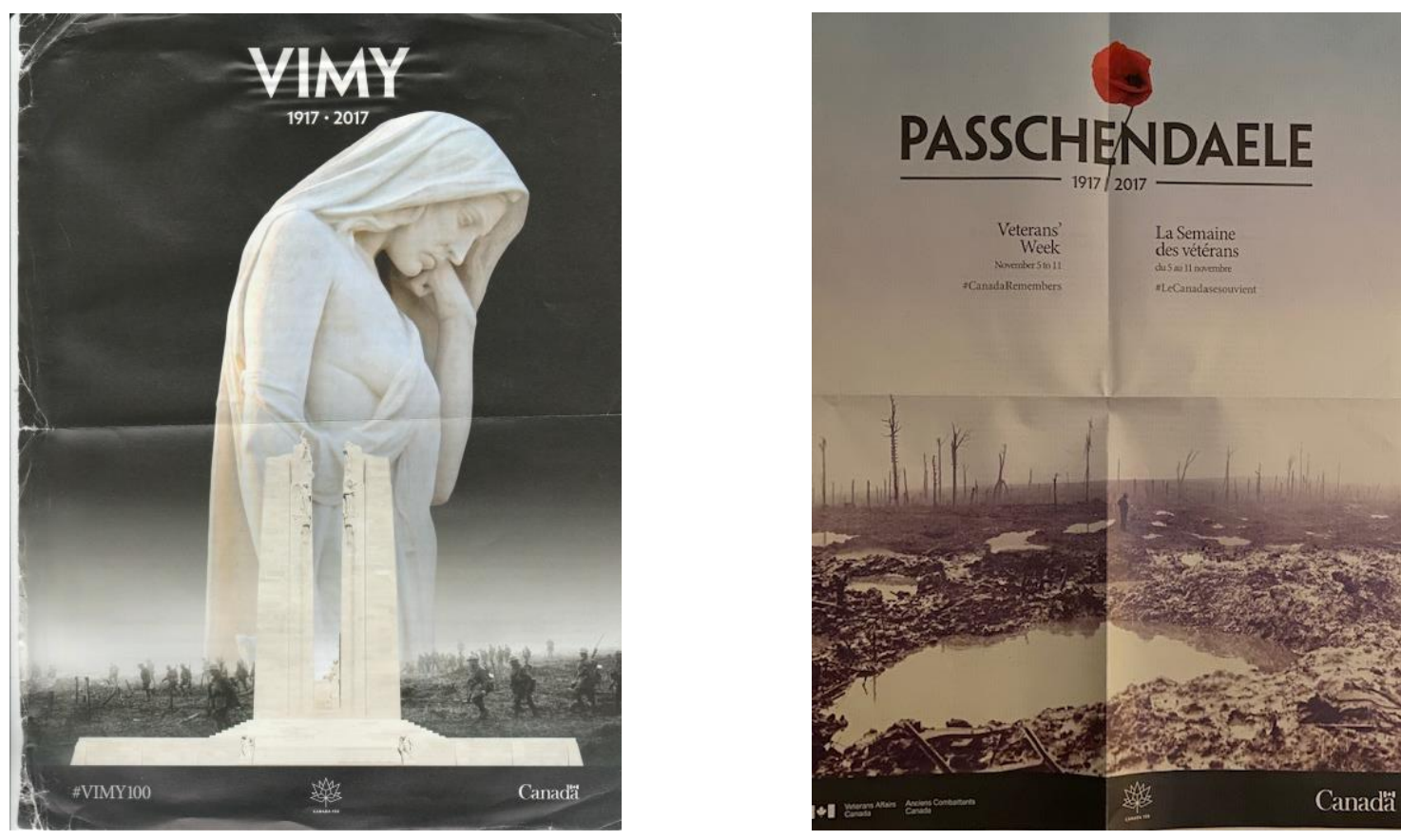

Figure 4.1 (left) and Figure 4.2 (right) - Vimy 100 poster and Passchendaele 100 posters with clear Canada 150 logos printed in the footer.

\footnotetext{
${ }^{32}$ It is interesting to note that the Beaumont-Hamel 100 promotional poster was not included in the ATIP materials I received. Maclean's published a full transcript and a video recording of Justin Trudeau's speech located here: https://www.macleans.ca/news/canada/prime-ministers-statement-at-the-vimy-fulltext/\#gallery/vimy/slide-1.
} 
Though the Road to 2017 created a tidy metanarrative, the above evidence shows it was ahistorical at times and it muddled the centenary and complicated the jobs of the public servants tasked with executing the plans as ordered by the upper echelons. And though this frustrated formally trained historians working in government, they did not have the power to decide the metanarrative. Second, as was argued in the previous two chapters, the commemorative assemblage (including the landscapes and bureaucracy) constrained what was commemorated given how the landscapes had been sculpted, and what was possible in terms of bureaucratic work. The Road to 2017 limited how the bureaucratic assemblages could deal with the "history" aspects of the First World War centenary. The early emphasis on the Olympics, War of 1812, and all the subsequent events that led up to the beginning of the centenary in 2014 overloaded the commemorative calendar and eventually limited the programming that could occur. Thus, there was no official commemoration of Moreuil Wood, little emphasis on Canada's Hundred Days, and less prominence of Indigenous commemoration because of cuts made to CIRNAC's commemorative program. The Road to 2017 was less concerned with the production of "history," and more focused on maintaining a collective national cohesion through the reproduction of a specific metanarrative related to the First World War. However, despite their best efforts to translate that metanarrative into commemorative practices, VAC planners received the inevitable criticisms anyway.

\section{Newfoundland and The "Squeaky Wheel"}

As my VAC interviewees shared, they expected criticism from media and other dissatisfied parties. As the artist Robert H. Thomson put it in our interview: 
They're [VAC] also trying to achieve consensus in the midst of a whole bunch of interested groups who all don't agree with each other 'cause they know they're going to be bitten by the veteran's associations if they do anything wrong and they're going to be bitten in public. When VAC is bitten in public by one veteran, it's in the news and suddenly the Government is in trouble. So, the folks at VAC have to walk a very wobbly board here because they have all these other legitimate interests, but they also know there are going to be very grumpy guys who will bite them in public and press. ${ }^{33}$

Referring to this phenomenon as "the squeaky wheel syndrome," VAC commemorative planner Robert Löken stated, "Unfortunately, that is always a challenge that we have ... for any organization holding events, that is what's going to be highlighted." 34 While the previous section of this chapter showed an "internal" critique of the Road to 2017 metanarrative's impact on the bureaucratic assemblage of the centenary, this section provides an analysis of the biggest "external" criticisms of each of VAC's "Big Three" commemorative events in chronological order, beginning with Beaumont-Hamel in 2016, then Vimy 100 (April, 2017), and finishing with Passchendaele 100 (November 2017). Each of these key events was emphasized because they each contribute to a narrative: Beaumont-Hamel is a cornerstone of Newfoundlander identity; Vimy is, as explained earlier, the perceived birth of the Canadian nation; and Passchendaele is sold as a victory and a further facilitator of nationhood. ${ }^{35}$

The Beaumont-Hamel commemorations often act as collision points between Newfoundland and the Government of Canada because the battle and its commemoration are ingrained in Newfoundland's sense of its pre-Confederation (i.e. pre-1949) identity. For example, a June 2016 Maclean's article quoted The Rooms' CEO, Dean Brinton,

\footnotetext{
${ }^{33}$ Robert H. Thomson, interview by Breanna Lester, September 16, 2019.

${ }^{34}$ Robert Löken, interview by Breanna Lester, November 20, 2019.

${ }^{35}$ ATIP, Steven Blaney, "Canada and the First World War Centennial," Veterans Affairs Canada, November 20, 2012.
} 
who discussed survey results asking Newfoundlanders about formative historical moments. ${ }^{36} 90 \%$ of those surveyed pointed to the battle at Beaumont-Hamel as a defining moment in the formation of Newfoundland. ${ }^{37}$ The article's author Patricia Treble commented that "[i]t's become a defining symbol in Newfoundland and Labrador, absorbed into its cultural DNA. Proof that the province is more than a time zone; it was once a dominion, a nation in its own right whose people fought and died in numbers that seem almost inconceivable today. ${ }^{" 38}$ Memorial University Events Coordinator, Douglas Ballam, shared similar sentiments. In our interview, he told me,

Beaumont-Hamel was not a nation building, but a pinnacle of national identity. It is to Newfoundland what Gallipoli is to Australia and New Zealand [....] There was about 12000 odd Newfoundlanders that served in various branches of the military, and British and Canadian forces as well and about half of those served in the Royal Naval Reserve from all parts of the island and from Labrador. That's unlike New Brunswick which had say three regiments and Nova Scotia, a dozen. There was only one from Newfoundland, so it was something that could easily focus people's remembrance and thoughts and nearly every household and community were affected. ${ }^{39}$

Though arguably less conflated with the birth of a nation than Vimy, the way in which Ballam described Beaumont-Hamel is also a historical and commemorative metanarrative, especially when it is coupled with how I described the sculpting of the Beaumont-Hamel landscape to comply with a narrow focus on Newfoundland in Chapter Two. In addition to providing an overview of what Beaumont-Hamel means to Newfoundlanders, Ballam also shared a story that accentuates how prominent BeaumontHamel still is 100 years on:

\footnotetext{
${ }^{36}$ The Rooms is the provincial museum and archives of Newfoundland and Labrador. https://www.therooms.ca/visit-us.

${ }^{37}$ Patricia Treble, "Beaumont-Hamel is Newfoundland's raw wound," June 22, 2016,https://www.macleans.ca/society/why-beaumont-hamel-so-close-our-hearts/.

${ }^{38}$ Ibid.

${ }^{39}$ Douglas Ballam, interview by Breanna Lester, July 27, 2019.
} 
There were several documentaries done over the commemorative period, and one of them (a Canadian producer) was here and they had some volunteers dressed in First World War uniforms for a re-enacting event. So, the Canadian producer was in the vehicle witnessing this happening, and he turned and noticed his driver (a Newfoundlander) was weeping, and that struck home for him how something that happened over 100 years ago still permeates in society. ${ }^{40}$

While incidents like this likely occurred elsewhere in Canada during the centenary, none of my other interviewees shared emotional stories of this kind. There was unusual passion in how Ballam discussed Beaumont-Hamel as ingrained in the imagining of what it is to be a Newfoundlander. Ballam was also the only one of my interviewees to describe the act of travelling to the battlefields as a 'pilgrimage.' When asked why he described it in this way:

There is absolutely no question that for Newfoundlanders, especially at Beaumont-Hamel, there is something spiritual about it. There is no question about that. You will hear ... the most common thing I hear from Newfoundlanders when they go to Beaumont-Hamel and step on the grounds is that ... something comes over them like a chill or ... they know and feel that they are on sacred grounds. ${ }^{41}$

This spirituality Ballam referred to could be a result of the stories he grew up with, but it was also a byproduct of the affecting landscape assemblage of Beaumont-Hamel that we examined in Chapter Two. However, like Vimy, not all Newfoundlanders viewed Beaumont-Hamel in the same way. The same Maclean's article cited above states that "Today, Beaumont-Hamel is widely perceived as the beginning of the end of Newfoundland's nationhood."42 A 2018 article in the Telegram quoted media liaison for Newfoundland Command (the legion in Newfoundland and Labrador), Frank Gogos'

\footnotetext{
${ }^{40}$ Douglas Ballam, interview by Breanna Lester, July 27, 2019.

${ }^{41}$ Ibid.

${ }^{42}$ Patricia Treble, "Beaumont-Hamel is Newfoundland's raw wound," June 22, 2016, https://www.macleans.ca/society/why-beaumont-hamel-so-close-our-hearts/.
} 
observation that Beaumont-Hamel is, "seeing a resurgence since the war in

Afghanistan." ${ }^{43}$ This is likely a consequence of the Harper government's efforts to unite all Canada's wars together into the metanarrative that was the Road to 2017. Nonetheless, July 1 is revered in Newfoundland and Labrador. This knowledge assists in explaining why many Newfoundlanders were deeply offended by the official commemorations of this important anniversary.

Discussing the centenary, Ballam told me that "[w]ith the Newfoundland pride in mind, we'd be quick to take perceived offense and slights, real or not at these commemorative ceremonies." ${ }^{\text {"44 }}$ Though he stated that he was not able to be present at Beaumont-Hamel 100 due to provincial commemorative obligations at home, he provided me with insight into what occurred at the 2006 commemorative ceremony:

The federal government also had a major pilgrimage that year to the sites, and they took the entire Royal Newfoundland Regiment and the band to France and Belgium, and that was rather long pilgrimage. Edwin Roberts was a LieutenantGovernor at the time. There were a number of flashpoints and conflicts between the Newfoundland delegates and Canadian delegation at that time. Here's a perfect example: In 1904, Newfoundland's anthem was written down (Sir Cavendish Boyle), called the "Ode to Newfoundland." During the First World War, that was Newfoundland's anthem, like O Canada. During the First World War, it was always Maple Leaf Forever. The Canadian soldiers marched to what they considered the Canadian song, but it wasn't the official anthem, Ode to Newfoundland was. When we do any military ceremonies here, we do Queen, Ode, O Canada in that order. We did many ceremonies in France and Belgium in 2006, and we do the Queen, Ode, O Canada ... automatically sing all three. The senior military officers of the Canadian delegation were aghast at the saluting of the Ode to Newfoundland and orders forbade the Newfoundland soldiers from doing it. And still today, that order still exists. Having said that, if there are no Canadian officers around, everyone salutes anyways. That's just an illustration. There were others. It's still quite close for Newfoundlanders. We can be offended whether the action is real or perceived [....] In 2006, we had a banquet in this beautiful church in Amiens. The Lieutenant-Governor of the province felt

\footnotetext{
${ }^{43}$ Millicent McKay, "Devastation, distinction: Battle of Beaumont-Hamel is etched in Newfoundland's history," November 10, 2018, https://www.thetelegram.com/in-depth/characters-of-strength/devastationdistinction-battle-of-beaumont-hamel-is-etched-in-newfoundlands-history-258056/.

${ }^{44}$ Douglas Ballam, interview by Breanna Lester, July 27, 2019.
} 
compelled to really tear a strip off the Canadian delegation for some of the things they had done along the same vein as 2016 (oversights and errors). He publicly stood up in front of the entire pilgrimage. Do you know what happened? The entire Newfoundland delegation stood up and gave him a resounding four-to-five-minute standing ovation. The Canadian delegation remained in their seats. ${ }^{45}$

These two stories from Ballam illustrate an historically fraught relationship between the federal government and Newfoundland. ${ }^{46}$ The latter comment particularly exhibits a clashing of federal and provincial protocol and a struggle for ownership over the commemoration of Beaumont-Hamel. Though Ballam was not at Beaumont-Hamel 100, his comments are important context for the criticisms that came out of the BeaumontHamel commemoration in 2016 explored below.

As Ballam suggested, the Beaumont-Hamel commemorations are moments of conflict between provincial and federal governments, but they are also complicated by when the battle occurred. The Battle of Beaumont-Hamel occurred on July 1, 1916, a day most Canadians recognize as Canada Day, a day to celebrate a confederated nation. For many Canadians, July 1 is a day off work, a day for beer, barbeques, gaudy red and white face paint, and firework displays. As Matthew Hayday explains,

1 July marks the anniversary of the creation of the Dominion of Canada with its four original provinces in 1867 [....] The first of July is thus not necessarily an obvious rallying point for all Canadians - but then so few things are in a country marked more by slow evolution and compromise than violent change or revolution [....] In 1958 federal officials selected the holiday of Dominion Day $[\ldots]$ to foster certain conceptions of Canadian identity. ${ }^{47}$

\footnotetext{
${ }^{45}$ Douglas Ballam, interview by Breanna Lester, July 27, 2019.

${ }^{46}$ For an in-depth examination of this historically fraught relationship, see: Sean Cadigan, Death on Two Fronts: National Tragedies and the Fate of Democracy in Newfoundland, 1914-34 (Toronto: Allen Lane, 2013).

${ }^{47}$ Matthew Hayday, "Fireworks, Folk-dancing, and Fostering a National Identity: The Politics of Canada Day," Canadian Historical Review 91, 2 (2010): 289.
} 
This day of celebration is complicated in Newfoundland and Labrador because it is also Memorial Day, a day of mourning for the loss of 324 lives on the morning of July 1, 1916 at Beaumont-Hamel on the first day of the Battle of the Somme. ${ }^{48}$ Though opinions on how July 1 should operate differ person-to-person, Telegram writer William Power insisted that the Newfoundland government should pass legislation declaring July 2 as Canada Day to keep July 1 as a memorial day. ${ }^{49}$ However, Doug Ballam was not bothered by the concurrent anniversaries:

Commemoration in the morning, celebration in the afternoon. Not to say there are no Canada Day events in the morning. You'll have a sunrise Canada Day celebration ceremony at Signal Hill, but in terms of the capital city, the morning is recognized as a remembrance for Beaumont-Hamel, so there the ceremony starts at $11-12: 30$ when things kick off at the provincial legislature where there is a Canada Day celebration with a garden party type deal. So, it's not viewed as a conflict or two opposing things really. In a way, the morning affirms a Newfoundland portion of our identity, and the afternoon affirms the Canadian part of our identity. My family visited the grave of the first Ballam, my first ancestor. He arrived here in 1864 and died in 1961. However (and I'm fiftyone), I'm a first-generation Canadian. It's often confusing to people from mainland Canada (the Newfoundland patriotism and what not), but that illustrates the point that I've been here for seven generations, but I'm a firstgeneration Canadian, so that history and sense of place still resonates. We see no conflict in recognizing our Newfoundland heritage in the morning and celebrating our Canadian union in the afternoon. ${ }^{50}$

As the above evidence suggests, there is division amongst Newfoundlanders as to whether Memorial Day should be independent of Canada Day, but that ultimately most do both, and indeed both support different aspects of a Newfoundlander's identity. As occasions with attached metanarratives, the clashing or coexistence of Memorial Day and

\footnotetext{
48 Jenny Higgins, "Newfoundland and Labrador in the First World War: Beaumont Hamel: July 1, 1916," Newfoundland and Labrador Heritage, https://www.heritage.nf.ca/first-world-war/articles/beaumonthamel-en.php.

${ }^{49}$ William Power, "The second battle of Beaumont Hamel," The Telegram, September 13, 2016, https://www.thetelegram.com/opinion/local-perspectives/the-second-battle-of-beaumont-hamel-136811/.

${ }^{50}$ Douglas Ballam, interview by Breanna Lester, July 27, 2019.
} 
Canada Day is another example of how metanarratives affect planning; both occasions are important to Newfoundlanders, and as the above evidence suggests, there is ongoing division on how best to include them. Nonetheless, this collision seeped into the First World War centenary and heightened how the Beaumont-Hamel event was adjudicated afterwards. By proxy, Beaumont-Hamel was anachronistically part of the Road to 2017 as a major First World War commemorative event, despite Newfoundland and Labrador's delayed confederation, and this likely exacerbated tensions after the event on July 1, 2016. As we shall see, some viewed aspects of this event - the muting of the minister and the swapping of flags, specifically - as a slight or an intentional misrepresentation of the historical battle as a coveted metanarrative for Newfoundland.

On August 1, 2016 (one month after the ceremony took place), The Western Star published an article with the title, "Apology in order." The article referred to what president of the Royal Canadian Legion Newfoundland and Labrador Command, Frank Sullivan described as a "slight" to the members of the legion in Newfoundland and Labrador. Sullivan communicated his frustration at the lack of participation granted to delegates from Newfoundland and Labrador, even though the story of July 1, 1916 is, for him, a Newfoundland story, not a Canadian one. ${ }^{51}$ Sullivan also noted that the Newfoundland presence in the ceremony in 2016 was "muted," given that he and his fellow delegates had "been doing this [participating in the Beaumont-Hamel ceremony] for years and [they've] always been front and centre." ${ }^{, 52} \mathrm{He}$ continued, criticizing VAC for excluding the province with a damning comment: "We were appalled by the lack of

\footnotetext{
${ }^{51}$ ATIP, Veterans Affairs Canada, "100th Anniversary of the Battles of the Somme and Beaumont-Hamel Tentative Schedule of Events," June 27, 2016; Barbara Sweet, "Apology in Order," The Telegram, August 1, 2016, https://www.saltwire.com/news/provincial/apology-in-order-43794/.

${ }^{52}$ Sweet, "Apology in Order."
} 
sensitivity shown by the organizers when the Newfoundland delegation was forced to take a back seat to the Canadian contingent brought by Veterans Affairs." ${ }^{, 53}$ This criticism is both symbolic and practical; it is concerned with the lack of representation, but also with the seemingly last minute decision to exclude the prepared speech of the province's Tourism, Culture and Rural Development Minister, Chris Mitchelmore, from the ceremony. ${ }^{54}$

In response to critics, VAC addressed a news article published on August 10, 2016 in The Telegram in which an anonymous source was outraged that the Premier of Newfoundland and Labrador did not have an opportunity to speak. ${ }^{55}$ In VAC's response, they expressed understanding at the frustration that comes with having to deal with the time constraints of large-scale events; after short speeches by the Prince of Wales, the French Secretary of State for Veterans Affairs and Remembrance, and Prime Minister Trudeau, and readings from a delegation of youth from Newfoundland and Labrador, the time allotted to Canada at Beaumont-Hamel was not enough to accommodate a speech from Mitchelmore as well. ${ }^{56}$ A September 2, 2016 article in The Telegram titled "How Minister's Speech Got Missed" stated that VAC's decision to leave Mitchelmore off the list of speakers was an oversight, and while they did "pencil him in" before the ceremony, the speech never happened because of a lack of time. ${ }^{57}$ In this situation, it

\footnotetext{
53 Ibid.

54 Ibid.

${ }^{55}$ This source referred to Chris Mitchelmore as the Premier of Newfoundland, but he was the Minister of Tourism, Culture and Rural Development in 2016.

${ }^{56}$ ATIP, Veterans Affairs Canada, "Op-ed Beaumont Hamel," August 5, 2016.

${ }^{57}$ Barbara Sweet, "How the Minister's speech got missed," The Telegram, September 2, 2016, https://www.thetelegram.com/news/local/how-ministers-speech-got-missed-127518/ (accessed July 11, 2020).
} 
appears that it was a logistical error on VAC's part; there does not appear to have been any malicious intent behind "muting" Mitchelmore.

By way of response to the above criticism regarding the suppressing of

Newfoundland culture in the Beaumont-Hamel ceremony, an internal email sent August

8,2016 by an unnamed VAC representative read:

We certainly engaged and shared our plans with the RCL [Royal Canadian Legion] but didn't necessarily work with them on the Overseas program. This was left with the Honour 100 group where they were delegation lead for GoNL [Government of Newfoundland and Labrador]. Veterans Affairs Canada worked with its partners, including the Government of Newfoundland and Labrador's Honour 100, the Royal Canadian Legion Newfoundland and Labrador Provincial Command and the Royal Newfoundland Regiment Advisory Council to put together a robust scenario and included a pre-ceremony program with music from Newfoundland and Labrador; tours with Parks Canada volunteers, many from Newfoundland and Labrador in period dress. The Master of Ceremonies, Padre and Bugler were all Newfoundlanders. ${ }^{58}$

This response shows an effort from VAC to attempt a working partnership with Newfoundland and Labrador and a recognition of their closeness to the events that occurred on July 1, 1916. This email also shows an array of stakeholder relationships that were involved in the Beaumont-Hamel commemorative assembly.

However, in our interview, Doug Ballam weighed in on the controversy over the minister's speech. He stated:

I guess they had the French flag, Canadian flag, and Royal Standard flag. The provincial representative, Mitchelmore, prepared a speech and then just didn't ... I don't think it was that they ran out of time. These things ... I've never seen that. In my hundreds and thousands of ceremonies, if it goes late, it goes late. You don’t say "oh shit sorry Minister, we don't have time.” It just goes late. So, he wasn't left off. He wasn't put on. ${ }^{59}$

\footnotetext{
${ }^{58}$ ATIP, Veterans Affairs Canada, “Op-ed Beaumont Hamel,” August 5, 2016.

${ }^{59}$ Douglas Ballam, interview by Breanna Lester, July 27, 2019.
} 
Whether warranted or not, the flag controversy and the decision not to include Minister Mitchelmore's speech in the ceremony were sticking points for Newfoundlanders in the aftermath of the ceremony. Given Ballam's previous experiences with the Canadian government, it is perhaps unsurprising he sensed some malevolence from VAC; he passionately reacted to an established pattern of a fraught relationship between the province and federal government.

The removal of the Newfoundland flag from the flagpole on the day of the ceremony did not assist in repairing this tumultuous relationship. In a Telegram article titled "The Second battle of Beaumont-Hamel," contributor William Power called attention to VAC's decision to remove the Newfoundland flag from the Beaumont-Hamel Newfoundland Memorial on the day of the ceremony and fly the Canadian flag in its place ${ }^{60}$ According to Power, VAC's decision to fly the Canadian flag over the Newfoundland flag was only symbolic of a larger issue of anachronism; the moment commemorated at Beaumont-Hamel is known distinctly as a Newfoundland moment, not a Canadian one. However, VAC's chief commemorative planner at Beaumont-Hamel, Peter Mills also weighed in on this criticism in our conversation. He said:

There was some [criticism] about flags that were flying low. Newfoundland didn't fight under the provincial flag, so there was this "why was the flag not there?" Well, Newfoundland fought under the Union Jack, it's not fighting under the provincial flag of Newfoundland. So, if you have three flag poles ... it's a Canadian site now because it was given to Canada to administer before it was administered by Newfoundland, flying the Union Jack because there you have our royal family represented, our most senior dignitaries that are there for the hundredth anniversary, and obviously the host nation is France, and you have senior officials there, so you have three flag poles, those are the three flags you're going to fly. Sorry, Newfoundland, but we are not going to fly your provincial flag. Beautiful flag, but really for today? Significance on that day,

\footnotetext{
${ }^{60}$ William Power, "The second battle of Beaumont Hamel," The Telegram, September 13, 2016, https://www.thetelegram.com/opinion/local-perspectives/the-second-battle-of-beaumont-hamel-136811/ (accessed July 12, 2020).
} 
mmm no. Doesn't measure up. What is missed... federal government was doing its utmost to commemorate the sacrifice of Newfoundlanders ... music chosen was Newfoundland, readings, representatives, program had pieces of Newfoundland poetry in it. Yeah, we might be the federal government sitting in Ottawa, but it's not like we don't know what happened on Beaumont-Hamel Day; we know exactly what happened at the Battle of the Somme and some of us (even though we are not Newfoundlanders) feel very very deeply about that. So, for you turn it into something political and to accuse those who are organizing it of being callous and not having any sensitivity or understanding of Newfoundland's sacrifice? Absolutely not, and if you can do a better job, take it over yourself and do it. We learned a lot there about exit process on a smaller scale that we then applied to Vimy, but again you're still constrained ... that access. As much as people hated it, the French dictated to us (as they had to) what the access protocol was ... centralized parking, departure by bus. We didn't have any control over that and respectfully to the French, nor should we. This is a country that's at war with terrorists, so they call the shots on that kind of stuff. $^{61}$

Though somewhat heated, this quote from Mills shows how much he genuinely cared about the event at Beaumont-Hamel and its success; he showed his interpretation of an historical moment and rationalised his decisions. These above discussions on both sides of the flag debate also shows just how complex and unstable commemorative assemblages are, and how even with the best of intentions, what is perceived correct to some may be of great offense to others. Mills' comments also once again illustrate arguments I made in Chapters Two and Three. Unless they were to erect an additional flagpole at Beaumont-Hamel in order to fly four flags, VAC had a difficult decision to make. And once again, this is an example of the protocol constraints VAC must adhere to, as well as those of other parties such as the French government, given that the event was held in France. As part of the federal government's commemorative plan for the First World War centenary, Beaumont-Hamel needed to fit into the Road to 2017 metanarrative. This helps explain why the British royalty, the French minister, and the

\footnotetext{
${ }^{61}$ Peter Mills, interview by Breanna Lester, November 20, 2019.
} 
Canadian Prime Minister were prioritized for speeches over Mitchelmore, and why the Canadian flag was chosen over the Newfoundland flag. Every planning decision needed to reflect and contribute to the Road to 2017 metanarrative. Furthermore, Mills' comment shows that VAC took the criticism from Beaumont-Hamel and tried to apply it to the Vimy centenary. It also shows his passion for what he accomplished, an impatience for criticizers who believed the decision to fly the Canadian flag over the Newfoundland flag was decided maliciously, as well as an exhibition of an historical understanding of Beaumont-Hamel's significance to Newfoundlanders.

Mills' revealing discussion on the flag debacle also considered a larger federal sensitivity to honour the memory of Newfoundlanders lost at Beaumont-Hamel. One of VAC's official responses echoes some of Mills' comments. In a formal reply to Frank Sullivan, they wrote:

Can we do better next time? Always. We will continue to work with our partners across Canada and anywhere across the world where Canadians answered the call to honour their sacrifice and bravery. That said, conversations surrounding the logistics of commemorative events such as this should not take place in a confrontational way through the papers. It is important to ensure the focus is on the sacrifice of those who did not return home. ${ }^{62}$

Though this response appears emotionless, it is official record, meaning it must be representative of the Department as a whole. The latter part regarding the control of logistical criticism is telling as well; VAC wanted to steer critical conversation away from the media to focus attention solely on the commemoration. This quote also harkens back to the discussion of metanarrative in the previous section in that the wording of the official correspondence preferred to focus attention on collective memory, not the flying of flags. The flag controversy is a further example of the clashing of history,

${ }^{62}$ Veterans Affairs Canada, "Op-ed Beaumont Hamel," August 5, 2016. 
metanarrative, and logistics I introduced in the previous section. As what occurred on July 1, 1916 is at the core of the Newfoundlander identity, the site's narrative arc reflects that idea. However, the site belongs to the Government of Canada since Newfoundland and Labrador confederated in 1949, the royals were present, and the site is in France. Unfortunately for the passionate Newfoundlanders, according to the above evidence, metanarrative lost to protocol at Beaumont-Hamel 100.

Though there was considerable criticism surrounding the event, there was also praise. An article published in local Newfoundland newspaper, The Gulf News remarked that the ceremony was "incredible." 63 Another article in The Telegram observed that the ceremony was a "moving and sombre event." ${ }^{64}$ However, commenting on the lack of a speech from Mitchelmore, the reported mentioned that "[i]t was left to our collective presence to represent the people of Newfoundland and Labrador as there was nothing said by any official representative of the people of this province on that momentous occasion." ${ }^{65}$ A further article published in the Pilot called it "moving" and "a fitting tribute." ${ }^{\prime 66}$ Overall, the Beaumont-Hamel controversy represented a clash of history and culture, metanarrative and strict logistical considerations, but above all, it shows that commemoration is not a zero-sum game, but rather a complex nest of decisions that can be misinterpreted since bureaucratic assemblages such as these are constrained by what they can do and what they can say. And though Mills referenced VAC's efforts to translate the feedback they received at Beaumont-Hamel to Vimy 100, Vimy was its own assemblage and therefore came with a whole different set of concerns. And at the top of

\footnotetext{
${ }^{63}$ Chantelle MacIsaac, “An incredible experience," The Gulf News July 8, 2016.

${ }^{64}$ Patrick Laracy, "Where once they stood," The Telegram 138 (84) July 16, 2016.

${ }^{65}$ Ibid.

${ }^{66}$ Jim Hildebrand, "Loss is still felt after 100 years," The Pilot 57(30), July 20, 2016.
} 
this list of concerns was something far away from the pretensions of the Road to 2017 but of immense importance to all who visited Vimy in April 2017.

\section{Toilets and Crowds at Vimy 100}

Toilets: this is what came to the minds of many of my interviewees when I referenced Vimy 100. The portable toilets at Vimy broke on April 9, causing massive line-ups and equally massive discomfort. From the outside, the malfunctioning toilets - in addition to the long wait times at entry and exit - appear to be the event's legacy from the outside, much to the frustration of the organizers at Veterans Affairs. The subsequent paragraphs provide an overview of some of the most scathing critiques participants had of Vimy 100, chief among which is the toilet debacle.

VAC is unpopular in the battlefield tour industry, especially around big anniversaries. Liberation Tours' John Cannon and Phil Craig had this to say about the whole ordeal:

Anything that VAC organizes is a shit show; it's a fucking shit show. They are not in the business of organizing big commemorative events and yet that's what they keep doing and they keep leaving it to the last minute and giving it to an intern and they get it wrong and they mess it up badly. We could do a whole hour conversation about Vimy with electric toilets that failed and how [veterans] were left out in the searing heat for two hours without liquid because I was in charge of them, and how we were deserted by VAC even after numerous requests to bring a coach up to get these veterans off the field. We were ignored while they carried young men and women into coaches and got them off the pitch first. It was absolutely disgraceful. The exit where we all herded onto the coaches through one little exit was completely undignified. It was horrible. And you have to think about ... I understand they had 22000 people there; you're going to hear a lot of different numbers, but that is what VAC ticketed is 22000 . We asked them six months in advance what the logistics would be. We got it fifty or sixty hours in advance in the middle of the night and it was stamped "draft." There we were the day before saying "this is what is happening tomorrow." We have 150 people at a lunch standing talking to our guests saying "no, there's no food. There is supposed to be water. You are all headed to a 
supermarket on your way back to the hotel and we're going to give you some money and you are going to go shopping for groceries and this is how the day is going to roll out tomorrow." We don't like leaving things until the last minute. That's not how we work and so for us it was exceptionally frustrating. ${ }^{67}$

In addition to the immense frustration of these independent battlefield tour operators as they recalled the events of April 9, 2017, Cannon and Craig pointed to a barrage of items, including malfunctioning toilets, crowd control, ticketing, performative elements of the ceremony, security, and a perceived lack of connection to place. Each merit further attention.

While sympathetic, Steve Harris also mentioned the toilets in our interview: At Vimy, VAC got slammed because the lack of toilets or perceived lack of porta-potties. They probably under-calculated the number of porta-potties they would require, but they under-calculated the number of porta-potties in part because they under-calculated the number of people who came and when you project out, you can never be sure how many people are going to come [...] What they couldn't control was the fact that the pumps that were emptying the porta-potties broke, so what do you do when the pumps that are emptying these damn things break? That's beyond your control. And it was beyond the control of the contractor whose job it was to empty the damn things. They broke! Why did they break? Bad pumps? Over-use? But they were confronted with a scenario for which there was no quick fix and they got shit for it. ${ }^{68}$

Harris' remarks allude to one of the central questions of this chapter: how could VAC prepare for the unexpected when planning these commemorative events? In this case, there was no way to know that the toilets would stop working, and yet fixing them became a priority to ensure the event continued to run smoothly. Executive Director of the Vimy Foundation, Caitlin Bailey also weighed in on the toilets issue,

The Vimy centennial was another example of a lot of public rage around how illprepared the site was. It was a big thing. My VAC contact ... if you talk about that will just look at you with this shell-shocked deer-in-the-headlights look because this was two and a half years of their lives doing this and the whole thing came down to 'there weren't enough public toilets' and that's everybody's

${ }^{67}$ John Cannon and Phil Craig, interview by Breanna Lester, August 13, 2019.

${ }^{68}$ Steve Harris, interview by Breanna Lester, August 1, 2019. 
memory of that centennial commemoration was the buses and almost getting crushed trying to get on the bus or getting stuck for three hours in the toilet line up. ${ }^{69}$

Bailey reveals a conflict between the soaring commemorative metanarrative at Vimy 100 and the embodied experience of the participants, all because of ill-functioning toilets. This is why it is so crucial to have contingency plans in place, and why logistics were so important to the First World War commemoration. Fields of Fire tour operator David Patterson, also commented on the toilet issue. He said, "I was standing there thinking 'there must be a website that tells you how many potties you need for 5000 people for eight hours and there is a website that tells you.' And they had one-tenth the number they needed." ${ }^{, 70}$ Inserting the caveat that "Normandy was 180 degrees in terms of their attitude and ability to react," and adding that he thought VAC had learned from the issues at Vimy, Patterson remained hopeful that what occurred at Vimy in 2017 would never occur again. $^{71}$

VAC planners were also aware of the toilets issue and were plagued by it in its aftermath. However, VAC planner, Sylvie Thibodeau-Sealy had a relatively practical explanation for why the toilets malfunctioned: "Some of the power had to be diverted more towards the sound which meant the power then was lessened on the toilets which means when you flush, there was less power for the water to flow, so it backed up."72 A caveat to remember in all this is that location has a large role to play in the functioning of things like electric toilets. Vimy Ridge is located amidst only a few small towns, the largest of which is Arras (just under twelve kilometers away). I did not find any evidence

\footnotetext{
${ }^{69}$ Caitlin Bailey, interview by Breanna Lester, July 24, 2019.

${ }^{70}$ David Patterson, interview by Breanna Lester, September 3, 2019.

${ }^{71}$ Ibid.

72 Sylvie Thibodeau-Sealy, interview by Breanna Lester, December 10, 2019.
} 
that there was any kind of contingency plan that included additional backup generators

nor was ever a consideration when planning for this event.

Though VAC received many complaints about the lack of functioning toilets,

Peter asked:

Does it behoove us in any way to push back and explain the difficulties encountered when you lose power in a rural setting for a short term that takes down toilets? No, I mean what good does fighting those or arguing those things do? [...] You're not going to argue with people complaining about toilets and water because at the end of the day these people have invested significant amounts of their own money to go and often remember their family members or loved ones. We're not in the business of arguing with Canadians about what a great job we did. We're hopeful that the great job shows, but if it doesn't, we've lived, we've learned, we move on to the next one. ${ }^{73}$

It might be of comfort to their critics that VAC seems to have taken Vimy 100 as a learning experience, but regardless, Mills' point is an important one. Mills and the rest of his team at VAC felt remorseful that the toilets failed because it took away from their commemorative message. Their roles are as servants to the public after all, and part of this service includes both a maintenance of the metanarratives that knit an imagining of Canada's national fabric, but also a service to ensure that the participants in commemoration (as a human process) are content, meaning they have food, water, shelter, and, yes, toilets. Consequently, their jobs are to care both about the commemorative metanarrative and the embodied experience of the public. Each needs the other.

During our interview, Peter Mills provided a potential cause of the major crowd control issue at Vimy 100. He explained:

There're so many moving parts. For example, the failure to execute on a small part of the plan ... the direction for removal of VIP and dignitaries from the circle at Vimy causes major headache down the road in getting the rest of the

\footnotetext{
${ }^{73}$ Peter Mills, interview by Breanna Lester, November 20, 2019.
} 
public off the site, so the "snake" as we called it was supposed to go one way and in the end the "snake" went the other way around that circle and that delayed things by several minutes, maybe an hour in terms of getting folks off, and the protocol around getting people off is very, very clear: until you move heads of state and government out, you're not moving anybody else; nothing is moving while those people are still on site, and those people were moving as expeditiously as they can on that day. I do remember being at what was supposed to be the head of the "snake" and having to tell my boss that actually it was the tail of the "snake" and we were in trouble. You adapt and overcome as best you can, but stuff happens. That was a question of a security officer not understanding their briefing and that briefing was provided over and over and over again, but that briefing was not followed, and that little change set off a chain reaction in other things. ${ }^{74}$

Here, Mills offered necessary insight into contingency planning at VAC. His evidence suggests that VAC planners were briefed and participated in a rehearsal before the event, however, due to sheer human error, their plans unravelled seemingly before their eyes. And here again, VAC planners were constrained by protocol; there was nothing they could do until they satisfied the protocols. His story also shows that even the slightest misstep can have catastrophic results, hence reinforcing the need for solid logistical planning.

Despite the setback caused by the mix-up at the podium, VAC organizers tried to get everyone off the site safely. Sylvie Thibodeau-Sealy explained: "No one had anticipated needing to do crowd-control to that extent. We're public servants. We're not crowd-control people [....] We had 20000 people there and the Gendarme that were there were there for security, not for crowd control $[\ldots .$.$] It was difficult for a lot of$ people. ${ }^{75}$ By all accounts, Thibodeau-Sealy’s story casts a previously unconsidered light on the events of April 9. Rather than conjuring an image of solemn commemoration, hers conjures one of chaos. Her comments also show that despite having a clearly defined role

\footnotetext{
${ }^{74}$ Peter Mills, interview by Breanna Lester, November 22, 2019.

75 Sylvie Thibodeau-Sealy, interview by Breanna Lester, December 10, 2019.
} 
as a commemorative planner, her position (and the positions of her team) had to shift to mitigate the unanticipated crowd control issue that presented on the day.

Though according to most sources, 22000 people were expected at Vimy 100 based on the number of tickets sold, knowing for sure how many people would attend to have the provisions necessary appeared a near-impossible task. As Harris indicated:

They had a registration process that worked for getting you down to the lower level, but almost anybody could have come to the upper level. They don't own the roads that all of the tour operators filtered their buses through ... sometimes the tour operators don't follow directions and they have their bus full of forty people and they haven't registered, and they drive to the goddamn site anyway and VAC can't control the operations of the independent tour operators. They can just give them best advice. ${ }^{76}$

This provides an alternate perspective to that of John Cannon and Phil Craig shared earlier. Considering this, and to be fair to the tour operators, it does not appear that the instructions were clearly communicated to them far enough ahead of the event to be implemented in time. Cannon and Craig recalled:

Phil and I had talked to VAC so many months in advance saying "you need to tell us where we are going, how many people will be there, what the dates are, the registration process" and they said "Well, eventually there will be this and there will be that and there will be registration" and we were understanding that whomever wanted to get into Vimy, will get into Vimy [....] Imagine now, we have 150 people booked, fully paid, non-refundable as of December 2016, hotels and coaches paid for, restaurants are booked, everything in place, and January 17 th, I'm standing in my kitchen cooking pasta with a glass of wine and I get an email from VAC saying 'Registration is now open for Vimy. You need to book up until the 20th of February, or until capacity is reached.' Those five words scared the shit out of me. So now there's a limit of the number of people. That can't happen because we can't write guests back who for two years had booked and say to them "Well, it turns out, they're only letting 14-15 000 people in. We sent all of you an email. Some of you got booked, but a bunch of you were away in Mexico and didn't get the email and now you're home and capacity is reached. So, you're on the tour - I can't refund you - for two weeks ostensibly to go to one big thing and that is Vimy, but I'm sorry, you won't get in because you aren't registered, you'll have to stay at the hotel." That customer is going to say "Boy, I want a refund." And we would say "You can't have a refund

\footnotetext{
${ }^{76}$ Steve Harris, interview by Breanna Lester, August 1, 2019.
} 
because all your money is gone." So, we explained all of that to VAC. We are not the only tour operator that has all the money invested. All of our people are expecting to get into Vimy, and if you [VAC] are now restricting the number of participants, I can tell you [VAC] that you have legal liability on your hands; you [VAC] had a lawsuit facing you if they don't all get in. The very next day, everything with Vimy changed and suddenly there was no restriction on capacity. If you were at the event, the entire section at the back of the monument with TV screens ... all of that came into being - we're pretty sure - because we wrote them a letter threatening a law suit if everybody doesn't get in because they had no clue that tour operators like us who bring $80-90 \%$ of clients to these events have been selling these tours for years expecting that everyone is going to get in because the Government had not said back in 2015 that there will be a limit of so many people, and if there is going to be a limit, give us enough for 1 coach; give us an assurance of fifty and we will sell fifty spaces, and then we will come back to you [VAC] and ask for another fifty and we will sell it and make sure those people will get in, but none of those logistics take place because VAC has no conduit of communications with the travel industry that is bringing the people to the event. ${ }^{77}$

However, according to Thibodeau-Sealy, it appears the ticketing system was imposed by the French government two weeks prior to the event; again, the internationalism of the First World War centenary created a complication for VAC's effort to plan a national commemorative event, and it also limited their ability to manage the assemblage.

Ultimately, Cannon and Craig's frustrations show a clashing of itineraries between VAC and Liberation Tours; from a logistics perspective, each of these groups had needs to fulfil, and their needs conflicted.

Furthermore, when asked about the registration policy at Vimy, David Patterson shared similar sentiments, though not in so many words. He said, "It was pretty bad. It was much better for Normandy, although Normandy was one third the number of people, but it is also a much smaller site." ${ }^{78}$ On the issue of ticketing, Patterson stated,

When people are deciding to go and they can't get into the ceremony, they're not going to go, so you can't wait until a month before they are going to tell them if they are going to get in or not. It's not going to be good. And the level of

\footnotetext{
${ }^{77}$ John Cannon and Phil Craig, interview by Breanna Lester, August 13, 2019.

${ }^{78}$ David Patterson, interview by Breanna Lester, September 3, 2019.
} 
documentation and the fact that they had to dump the registration process and re do it and tended to forget that people would be leaving to go on the trip, it's not just about Vimy. And they had to print the physical paper, but if they are travelling in Europe two weeks before that, they aren't going to be able to do it. $^{79}$

It appeared the physical ticketing process was especially frustrating to have to navigate prior to Vimy 100, especially for tour operators who had promised their clients a specific experience and was then left scrambling to abide by the new rules VAC set out without ample notice. Patterson's words also exhibit a disconnect between VAC's commemorative assemblage and that of the battlefield tour operators; the consideration of physical ticketing and registration was far more catastrophic to the battlefield tours than VAC may have realised in the moment.

When I raised the issue of security in conjunction with the ticketing conundrum to

Sylvie Thibodeau-Sealy, she stated,

When you have large crowds with limited access, for sure there is going to be line-ups. It's not just an open field where you can just get on it. There are very limited and specific entry points. There was also a lot of security requirements around that because in France, there is a heightened sense of security there, so individuals needed to be padded down, and bags were checked. So, a minute per person, that's 20000 people coming in. That's a lot of time. So, already coming in, you were having to deal with a crowd that was happy to be there, but it took forever to get in. That was intense. They needed to have a ticket that was scanned and that was imposed by the French government two weeks prior to the event. So, they had a bunch of people that had already registered, had tickets, but the tickets were not valid because they weren't scan-able. There was a lot. It was a lot $[. . .$.$] There were a few people for which the Embassy did tell us that there$ was no way they were coming in here. They have a record or whatever it is. There was a list of individuals that were not permitted to get in, so that was another thing to manage and keep on track of. The local authorities took care of that. ${ }^{80}$

\footnotetext{
${ }^{79} \mathrm{Ibid}$.

${ }^{80}$ Sylvie Thibodeau-Sealy, interview by Breanna Lester, December 10, 2019.
} 
Indeed, security was a massive issue, and Thibodeau-Sealy's insights show just how complicated, stressful, and frustrating a consideration imposed by other parties can be. Everyone I spoke with understood the state of security France contended with in 20162017. Discussing the ninetieth anniversary at Vimy, David Patterson stated, "I was at the ninetieth anniversary. It was nowhere near the same security. In between, you had things like ISIS and that kind of stuff, so it's understandable." ${ }^{\prime 1}$ Canadian Battlefields Foundation tour operator Jérémie LeBlanc also discussed security. Describing the experience of waiting in the security lines, he said, "When you go to these large ceremonies ... the security and everything else. That's fatiguing." ${ }^{82}$ Undeniably, standing in long lines just to enter an event is often a tedious and annoying experience. However unfortunate, in the end, the security concerns and constraints were noticeable. When asked what Caitlin Bailey remembered about the event, she said, "If you ask me, I do not remember the ceremony. I remember being on site at six o'clock in the morning because the security closed at 6:30. I remember sniffer dogs in our activation tent, and I remember waiting two hours for the bathroom, and I don't remember anything else." ${ }^{\circledR 3}$ Bailey's remarks showcase a conflict between the practical and narrative components of commemorations; if the basic needs of the people who attend them are not met, the overall message is lost and the commemorative moment becomes less affective. Rendering an event forgetful is the last thing VAC planners want after spending years in preparation for an event.

\footnotetext{
${ }^{81}$ David Patterson, interview by Breanna Lester, September 3, 2019.

82 Jérémie LeBlanc, interview by Breanna Lester, August 27, 2019.

${ }^{83}$ Caitlin Bailey, interview by Breanna Lester, July 24, 2019.
} 
However, gaining perspectives from those on the inside provides a more fulsome explanation for these long and frustrating lineups. As Peter Mills explained,

In terms of Vimy 100, there is no major commemoration prior to Vimy 100 that would have seen the same level of security threat being experienced in France at the time, nor the level of engagement by the French Government in controlling access to the event and so much of what was identified as a problem or challenge coming out of Vimy was driven by the nature of the current environment in France and the need for French officials to ensure the safety and security of all there and so while it would be nice for everyone to be able to arrive a few hours before an event and come and go as they please, when you have heads of state and heads of government on a very rural site without quick access to hospital and other infrastructure, a lot of planning and a lot of constraints were placed on the management of the site before we even began. ${ }^{84}$

In this case, it appears VAC took the brunt of the blame for a situation that was largely out of their control or odds that were stacked against them from the very beginning.

Interestingly, though, twenty-year commemorative planning veteran Christina Gaudet, offered some context. When asked about the security concerns at Vimy, she stated,

Yeah, that was big, but in all honesty, we did Normandy in 2004 and 2004 was not that long after 2001 that changed the face of security across the World, and I didn't go to Normandy last year, but I can tell you that in 2004 when George W. Bush was coming and we had the Queen, not the Crowned Princes, security was a massive issue then too. It changes depending on the country and the events and who else is attending, but it has been ever-present for a long time. 2017 was intense and it was intensified because of the President of France, whereas in the past, we had the Prime Minister of France at 2007 at Vimy, we had the Prime Minister and the Queen. Security was still an issue, but it wasn't that much of an issue at that one. ${ }^{85}$

So, despite the ever-looming security threats, attacks, and policies in France at the time of Vimy 100 , security appears to have always been a concern, though perhaps it was severely intensified by the sheer volume of people expected, the ticketing system in place, and the specific dignitaries in attendance at the event.

\footnotetext{
${ }^{84}$ Peter Mills, interview by Breanna Lester, November 20, 2019.
}

${ }^{85}$ Christina Gaudet, interview by Breanna Lester, January 22, 2020. 
However, despite the barrage of complaints filed against VAC's commemorative efforts, most all the VAC employees that were on the planning side were proud of what they accomplished. Referring to the Vimy event as a "spectacle," Peter Mills communicated with pride that "given the situation we are working with in terms of the environment (physical and political) [we] deliver[ed] something quite extraordinary on April 9th. ${ }^{86}$ Christina Gaudet echoed Mills’ sentiments:

Honestly, we had a few complaint letters of people who were there that got caught up in some of the ... nothing is ever fool-proof $100 \%$ and there were a few little booboos or difficulties with traffic flow and stuff, but really if you consider that we had 25000 people there and maybe 150 people were upset enough to write. That's pretty darn good. ${ }^{87}$

Though they would also likely all agree that there was much to learn from the Vimy event (unpacked further in this dissertation's conclusion), Gaudet's anecdote suggests that it was considered an overall success by most, and something to be proud of.

The commemorative landscapes of the First World War, including Vimy, seek to nurture both a shared and personal connection to the battlefields as a place, and for some critics there was little to no opportunity for that balance in their experiences at the Vimy 100 event. Some of my interviewees commented that their own connection was lost with the place on that day. Perhaps this is why Caitlin Bailey shared in our interview: "For me, it is a very private thing and entirely divorced from my public activities as a commemoration professional. As a professional, I go to every commemorative ceremony you could possibly think of. In terms of private activities, I see a very big space between

\footnotetext{
86 Peter Mills, interview by Breanna Lester, November 20, 2019.

${ }^{87}$ Christina Gaudet, interview by Breanna Lester, January 22, 2020.
} 
public and private." ${ }^{88}$ David Patterson agrees to a certain extent. When discussing his 2017 Vimy tour with me, he stated:

The people who came on my Vimy trip never got to set foot on the Vimy memorial, so when I went back with my Normandy trip, we also got to go to Vimy. The memorial was blocked off for days beforehand. You got to see it and be there on the day, so it was a shared experience with 25000 other people, but how much of a connection with the ground? You can't see the ground with 25 000 people there. Turns out, all the things you want to see on a battlefield tour ... it is about the ground and going to the places where things happened. I was so far away that I was watching on a big TV screen. ${ }^{89}$

In Chapter Two, I argued that experiencing a connection to place assists in drawing people to the sites. VAC was aware of this and did attempt to facilitate a connection through program elements. According to Bailey, "The things that stand out to me as things that were well done are the idea of laying the soldiers' boots at Vimy; one pair for each name on the monument. That was a really personal moment and a lot of people really connected to that." ${ }^{90}$ It is these kinds of efforts that were memorable to the people who experienced them, and despite everything that went wrong on the day, it is perhaps comforting to the VAC planners that some of their programming retained its power and remained meaningful to at least some of the people who were on site for Vimy 100.

\section{The Public Speaks Back}

In the previous section, Christina Gaudet mentioned that several people wrote to VAC to communicate their dissatisfaction with Vimy 100. This section unpacks some of these responses that I received as part of this project's ATIP returns. Most important are several partially redacted letters critical of the commemorative event at Vimy on April 9,

\footnotetext{
${ }^{88}$ Caitlin Bailey, interview by Breanna Lester, July 24, 2019.

${ }^{89}$ David Patterson, interview by Breanna Lester, September 3, 2019.

${ }^{90}$ Caitlin Bailey, interview by Breanna Lester, July 24, 2019.
} 
2017. On April 12, 2017, only three days after Vimy 100, General Walter Natynczyk, Deputy Minister of Veterans Affairs, received an email from an unknown person who stated they had participated in "pilgrimages" to First and Second World War sites, was present at the Vimy 100 ceremony, and had a personal connection to the battlefields. After describing an exciting beginning to their "pilgrimage," the writer deemed the Vimy 100 event a "total disaster." 91 The writer laid out eight specific points of concern. First, they stated that they waited two to two and a half hours for a shuttle to the site, walked one kilometre to the baggage check point, and was unsatisfied with the ratio of bag checkers to attendees. Second, the writer stated that their bus arrival time was altered by two hours the night before the event, while others who ignored their tickets were able to enter earlier. The third concern had to do with the allocation of seating for youth; the writer noted that youth representatives were given preferred seating, while this person and their party were forced to sit on the grass on the opposite side of the monument away from the video and audio system. Fourth was a lack of sufficient bathroom facilities; some waited in line for an hour to use the toilets, coupled with a lack of food and water provisions, and shade for seniors. ${ }^{92}$ The remaining four points concerned crowds and timing; the frustrated writer compared waiting in line to access the memorial as "cattle being herded into cattle trains. ${ }^{, 93}$ Furthermore, for the benefit of national television and due to the time change, many were awoken early in the morning to then wait for a 4 p.m. ceremony, and did not return to the hotel until 11:30 p.m. ${ }^{94}$

\footnotetext{
${ }^{91}$ ATIP, Redacted email to Deputy Minister of Veterans Affairs, "Vimy 100 Ceremony April 9, 2017," April 21, 2017.

${ }^{2}$ ATIP, Veterans Affairs Canada, "Proposed email response from Deputy Minister re Vimy 100 Ceremony April 9, 2017," May 15, 2017.

${ }^{93}$ Ibid.

${ }^{94}$ Ibid.
} 
In his response dated May 15, 2017, more than a month after VAC received the initial letter, General Natynczyk stated: "We worked closely with French officials, the Canadian Embassy and other key partners for months to develop a plan that would support the maximum number of interested Canadians, local French citizens and others to participate in this historic event. ${ }^{\text {"95 }}$ Natynczyk's response continued with a relatively detailed rationale for the time constraints experienced on the day, indicating that for security reasons, participants had to be on site by 3:00 p.m. Furthermore, Natynczyk stated that all tour outlets, and those who purchased tickets were warned to expect delays. VAC's plan was modeled after the transportation system used successfully by France for the UEFA European championship for football in the summer of 2016, and the decision to install large screens at the site was based on Canada Day celebrations on Parliament Hill in Ottawa. ${ }^{96}$ In response to the toilet issue, Natynczyk communicated that a power outage in the afternoon of April 9 caused the limitations on toilet availability for a "period of time." $" 97$ In terms of seating, Natynczyk stated that "Veterans Affairs Canada was reliant on the registration process and tour operators to provide the information required to identify those who should be seated. I am very sorry to learn that the volunteers you encountered were unable to direct you to the appropriate area." ${ }^{98}$ After thanking the writer for their time in addressing the issues, Natynczyk wrote that their "points have been carefully noted along with all of the other comments we [VAC] have received." ${ }^{99}$ It is pertinent to note here that Natynczyk's comments reflect VAC's

\footnotetext{
${ }^{95}$ Ibid.

${ }^{96}$ ATIP, Veterans Affairs Canada, "Proposed email response from Deputy Minister re Vimy 100 Ceremony April 9, 2017," May 15, 2017.

${ }_{97}$ Ibid.

${ }^{98}$ Ibid.

${ }^{99}$ Ibid.
} 
planning process discussed in the previous chapter; Natynczyk's remarks reveal a consultation process, a careful consideration of logistics, and an explanation of the other large issues (such as toilets and time in line) as a byproduct of the volume of patrons and limits imposed on VAC by the French government and their own protocols.

On April 12, 2017, General Natynczyk received another letter of complaint. This letter was written as a ten-point criticism in response to the events of April 9. The writer had many similar concerns to the above, though the tone was more polite. The writer first commended VAC on an otherwise successful event but called it a "major disappointment" as a spectator attempting to witness the ceremony from behind the memorial. ${ }^{100}$ They acknowledged that some of the difficulties experienced on the day were not under the supervision of VAC, however, the writer ultimately attributed their qualms to "poor planning by Veterans Affairs Canada and associates." 101 Though this writer was concerned with similar issues to the aforementioned letter, namely respect paid to seniors and veterans, this particular letter had a significant comparative angle. For instance, this writer stated that at the 2007 and 2012 ceremonies, seniors were given priority access to the site above students, an action that was not taken at the 2017 ceremony. ${ }^{102}$ Furthermore, the writer critiqued the placement of the screens, stating that there was considerable glare from the sun, and various other obstructions which impacted the experience. The writer specified that similar issues occurred at the seventieth anniversary of D-Day ceremony in $2014 .{ }^{103}$ The post-2015 change introduced by the Liberal government partially explains why priority seating was given to youth, a decision

\footnotetext{
${ }^{100}$ ATIP, Walter Natynczyk, email to unknown recipient, "Vimy 100 ceremony," April 25, 2017.

${ }^{101}$ ATIP, Walter Natynczyk, email to unknown recipient, "Vimy 100 ceremony," April 25, 2017.

102 Ibid.

${ }^{103} \mathrm{Ibid}$.
} 
of inclusion that created an effect of exclusion (at least from the perspective of this letter writer.) Despite the fact that VAC could not control the weather, I did not see any evidence of glare being a consideration.

Another interesting aspect of the April 14 letter is the commendations paid to the 2004 D-Day and 2007 Vimy ceremonies. The writer questioned: "Who was the DeputyMinister, who along with his staff, orchestrated the fabulous 2004 D-Day sixtieth Ceremony at Juno Beach? Hasn't VAC learned anything from these former staff members and commemorations?" 104 In response to the toilet issue, the writer questioned why VAC had not learned from the toilet insufficiencies experienced at the seventieth DDay ceremonies where "lines for the few portables stretched beyond forty yards." ${ }^{105}$ The writer continued, stating that it has been made clear to them since the 2009 D-Day ceremony that:

VAC does not care for the satisfaction or welfare of the average traveller from Canada [.... The attitude of VAC, the organizers, and the authorities is not exactly an example of the servant leadership displayed by commanders such as Currie and Byng in April 1917, whose concern was for the welfare of every soldier, including the lowly private. ${ }^{106}$

These statements are intriguing for many reasons, not least of which is the comparison made by this writer between the VAC organizers and historical commanders Arthur Currie and Julian Byng. This statement also implies a connection between the visitor and the soldier. These comparisons show a layering of embodied experience. It is also interesting that the anonymous writer questioned the transfer of knowledge between planning teams for each ceremony. However, it is worth noting here that according to a

\footnotetext{
104 Ibid.

105 Ibid.

106 ATIP, Walter Natynczyk, email to unknown recipient, "Vimy 100 ceremony," April 25, 2017.
} 
Globe and Mail article on the 2004 D-Day ceremony mentioned in the above critic's comments that "about 6000 veterans, their family members and local residents" attended the commemorative ceremony, meaning that it is likely the crowds were thinner at this event than at Vimy $100 .^{107}$

Finally, the anonymous writer suggested VAC write to the major tour operators with an apology: "these travel agencies often end up with egg on their face or appear as offering false leaders to get people to sign up for such trips to attend such important ceremonies." 108 After expressing doubt that an apology of this kind would ever occur, the writer signed off. Having discussed Vimy 100 with both tour operators and VAC employees, perhaps this anonymous writer is correct in identifying that a more transparent or collaborative approach would have avoided many of the above-mentioned criticisms, and perhaps they could in the future.

General Natynczyk responded to this letter as well, this time on April 25, 2017. His response was a condensed version of the letter he wrote on April 12, using almost identical wording. However, and perhaps appealing to the letter writer's own invocation of military history, Natynczyk added that this particular letter would be part of VAC's "after-action review process." ${ }^{109} \mathrm{He}$ also assured the writer that their feedback "w[ould] help [VAC] strengthen the delivery of future large-scale Veterans Affairs Canada-led overseas commemorative events." ${ }^{110}$ And, given the critical silence in the newspapers after Passchendaele 100, it might have done just that.

\footnotetext{
107 Globe and Mail, “Canadian veterans return to Juno Beach,” June 6, 2014, https://www.theglobeandmail.com/news/national/canadian-veterans-return-to-juno-beach/article24357684/.

${ }_{108}$ Walter Natynczyk, email to unknown recipient, "Vimy 100 ceremony," April 25, 2017.

109 Walter Natynczyk, email to unknown recipient, "Vimy 100 ceremony," April 25, 2017.

${ }^{110}$ Ibid.
} 
Passchendaele, while still of great importance to VAC's commemorative efforts, was less criticized than the Vimy or Beaumont-Hamel centenary events. However, Passchendaele 100 was discussed several times in both my interviews and the ATIP material. When asked why Passchendaele was considered part of VAC's 'big three' events, Steven Harris stated:

You can tell the story of a blood bath where the Canadians come in at the last moment and takes the Ridge. It's a success. So, you're combining the drama with a sense of futility and sense of hardship on the part of the individual soldier that you get on the first day of the Somme, but you add "the Canadians come in at the last moment and take the ridge." 111

Some of the ATIP documentation adds to this narrative arc. In a project description for the Memorial Museum Passchendaele 1917 dated March 5, 2015, it was communicated that Passchendaele was "considered to be Canada's coming of age as a nation, along with the Battle of Vimy Ridge." ${ }^{12}$ In a slide deck prepared by VAC and presented on November 20, 2012, the presenters notes discussed Vimy as "a distinctly Canadian triumph, helping create a new and stronger sense of Canadian identity. This was further forged in the mud of Passchendaele." ${ }^{\prime 13}$ However, despite its status as one of Canada's "big three" First World War commemorative ceremonies, I found little criticism in either the ATIP material or in conversation with my interviewees. ${ }^{114}$

The only mention of Passchendaele 100 criticism I heard from my interviewees was Peter Mills' comment that: "The idea that there was not significant planning that

\footnotetext{
${ }^{111}$ Steve Harris, interview by Breanna Lester, August 1, 2019.

112 ATIP, Veterans Affairs Canada, "The Road to 2017: Commemoration Initiatives," March 5, 2015.

${ }^{113}$ ATIP, Steven Blaney, "Canada and the First World War Centennial," Veterans Affairs Canada, November 20, 2012.

${ }^{114}$ The lack of critical discussion on the Passchendaele commemoration in the ATIPs is also likely due to the timing of my submissions. Due to time constraints for this project, all ATIP submissions were complete by summer 2017, meaning Passchendaele 100 had not yet occurred. ATIP officers are also not allowed to release information on events not yet transpired, so I received very little on Passchendaele, and even less on the criticisms or success of the event.
} 
went into Vimy or Beaumont-Hamel or Passchendaele (which was on a much smaller scale) the idea that that wasn't an intense and long and complex exercise is certainly [an error]." ${ }^{115}$ Mills also added that "We [VAC] certainly learned a lot at Vimy that we applied to Passchendaele." 116 It is possible that the logistical lessons learned at Vimy and Beaumont-Hamel were applied to Passchendaele, or perhaps the smaller crowd at the ceremony assisted. Nonetheless, Passchendaele stands as possible evidence that VAC organizers listened to and implemented changes as a result of criticisms they received after prior events.

Criticisms of the First World War centenary were numerous and came from all sides: the media, scholars of history, battlefield tour operators, even public servants in other departments, but an important caveat to all this is that there are third parties who, despite having critiques of their own, understood VAC's situation. DHH historian Steve Harris, called VAC's duties “intensive work [...] it's hugely complex and it's expensive." 117 David Patterson also understood: "It's dramatic, but Veterans Affairs learned a lot of lessons from Vimy and the logistics of it as well. It was a combination of a massive event and very little capacity to plan. The same people were doing all these centenary events and so they can only focus on one thing at a time."118 Patterson's comments foreshadow the topic of the next chapter; though as a department, VAC was not wholly successful in its commemorative endeavours, Patterson understood that the VAC labourers were fatigued and lacked the working conditions to perform at the level required to produce a flawless event.

\footnotetext{
115 Peter Mills, interview by Breanna Lester, November 20, 2019.

116 Ibid.

${ }^{117}$ Steve Harris, interview by Breanna Lester, August 1, 2019.

${ }^{118}$ David Patterson, interview by Breanna Lester, September 3, 2019.
} 


\section{Conclusion}

Returning to Caitlin Bailey's comments in the epigraph of this chapter, commemoration is about the interplay between metanarrative and embodied experience; any identity forming or memory securing that defines the purpose of commemoration to scholars and those working at the highest levels of the federal government is lost if the basic needs of participants are not met. Without functional relationships between stakeholders, working toilets, efficient security, food, and shelter, the affective experience is soured, and the significance of the moment diminished.

Though the Road to 2017 was a convenient way to organize an almost decadelong commemorative period, it created a collision of many assemblages, certain parts of which were unsavoury to the media, veterans, scholars, tour directors, and other third parties. Though this commemorative period was less about an accurate representation of history, and more about ensuring every commemorative event contributed to the Road to 2017 metanarrative, VAC worked tirelessly to deliver successful commemorative programming. However, as we will see in the next chapter, these efforts, and the criticisms they insighted, also left an emotional impact on those whose job it was to plan and execute what is described in the next chapter as a hectic, stressful, and ultimately fatiguing period for many commemorative planners.

The second section of this chapter analysed the issues associated with the embodied experiences of planners as they participated in the planned commemorations and often showcased a conflict between the intended message (or metanarrative) and the affective connection that empowers these commemorative moments. Though there were Newfoundlanders who felt Beaumont-Hamel was a success, the muting of Mitchelmore 
and the flag controversy (in efforts to comply with the Road to 2017 metanarrative) added to the existing fraught relationship between the province of Newfoundland and Labrador and the federal government, and consequently tainted the events of July 1 , 2016. At Vimy 100, despite years of planning and creativity in how they approached cultural programming at the event, the malfunctioning toilets, exceedingly long line-ups, security checks, and a lack of food, water, and shelter diminished VAC's abilities to establish an emotional connection between the participants and the grounds upon which they stood. And, though Passchendaele was less a subject of public scrutiny and more of an overall success, it stands as potential proof that VAC planners listened to and implemented changes to their programming because of the issues that occurred at Beaumont-Hamel 100 and Vimy 100.

This chapter also exposes the fragility of commemorative assemblages through some of the criticisms VAC received in its wake. As the VAC planners and stakeholders I quoted earlier in this chapter recognised, criticism is an inevitable part of their commemorative work. Assemblage assists in understanding why this is; if assemblages are as fluid and unpredictable as theorist Manuel DeLanda suggests, there will always be points of conflict. While there are things VAC planners could have done to mitigate some of these issues, ultimately the process of commemoration is fluid by virtue of its assemblages and is therefore prone to change at any moment, and without warning. Commemorative events such as those at the three battle sites are always vulnerable and fragile, and this makes contingency planning difficult, yet necessary.

These difficulties in both the planning and administration of First World War commemorations often made the work grueling, tiresome, stressful, and exhausting. It 
even altered the careers of some of these commemorative workers. Throughout this chapter, I have alluded to some of these emotional responses, but the following chapter further analyses the emotional toll commemorative work had on those who experienced it firsthand. 


\section{Chapter Five: \\ Emotions, Work, and Commemorative Assemblages}

I'm transitioning out of my [commemorative] events world because of personal

challenges, and what I find is ... the personal challenges, or the personal drain or draw is too much for me now because I am a little bit older and I have two kids who have very busy schedules, so to do ministerial events, run large-scale events... It's not even the travel; I love delivering an event, I love the adrenaline, I love being on the ground, I love working with my colleagues and the team, and working until one, two, three o'clock in the morning, getting up at six and doing it all again, that's not so much the issue, but it's a reality in this type of work. It's the challenge of managing such diverse requests and demands and information. It's the ten-hour days every single day for months leading up to the delivery of the ceremonies that is too much a personal challenge for me and my family.

-Christina Gaudet, Senior Program Manager, Manager of Public Events, Veterans Affairs Canada $^{1}$

\section{Introduction}

Christina Gaudet spent roughly twenty years working in the Commemorations Division at VAC before she decided to transition out. Her colleague, Sylvie Thibodeau-Sealy, also suffered personal and professional challenges. She told me: "It was probably the hardest thing I've ever done in my entire career and I don't think anything will ever compare."2 Though both of these women also made it known that they have great love for their roles and are proud of what they accomplished, the commemorations that occurred between 2014 and 2018 had an immense and unforgettable impact on each of them personally. As previous chapters have explained, commemoration is difficult work and because commemoration is a human process, emotions play an impactful role in how the work is performed, experienced, and remembered. Consequently, this chapter explores the

\footnotetext{
${ }^{1}$ Christina Gaudet, interview by Breanna Lester, January 22, 2020.

${ }^{2}$ Sylvie Thibodeau-Sealy, interview by Breanna Lester, December 10, 2019.
} 
emotional implications of commemorative labour as it relates to the assembling of the First World War centenary.

Unlike the previous three chapters, this chapter relies almost entirely on the conversations I had with the commemoration professionals I interviewed as it was only through talking to workers that I was able to more fully understand the role emotions played in their everyday work. Though the ATIP returns were invaluable in aiding my understanding of how government operates from the inside, the documents (as official record) lacked feeling. Similar to Jiwani and Krawchenko's observations that using both ATIP and interviews enhanced their study, I found my interviews added an emotional dimension to my understanding of commemorative work. ${ }^{3}$ This is central to my argument that commemoration is more than a ritual act performed by a governmental monolith; it is rather an unpredictable process of assemblage orchestrated by labouring individuals who, though they felt stress, pressure, fatigue, and eventually burnout, persevered, adapted to unfavourable working conditions, and perhaps even found joy in the work they did. However, there was an emotional cost to this that will be explored in the subsequent pages.

Accordingly, this chapter first draws on the work stories I heard in my interviews, paying particular attention to the stresses, fatigue, and burnout they felt as they performed their individual roles. Within this discussion, I examine how their working conditions played a part in facilitating these emotional responses, and the affect they had on their families, their well-being, and some of their ultimate decisions to change jobs. And,

\footnotetext{
${ }^{3}$ Farzana Nanji Jiwani and Tamara Krawchenko, "Public Policy, Access to Government, and Qualitative Research Practices: Conducting Research within a Culture of Information Control," Canadian Public History 40, 1 (2014): 57-86.
} 
finally, this chapter discusses the ways in which, despite the hardships, my interviewees were proud of and felt joy as they performed their tasks.

The commemoration professionals I interviewed often experienced what sociologist Arlie Russell Hochschild termed in 1983 as "emotional labour." By her definition, emotional labour is the "management of feeling to create a publicly observable facial and body display."4 Hochschild's focus on the airline industry and the ways in which flight attendants were often asked to serve customers with friendly demeanors and a smile. ${ }^{5}$ As she argues, the constant show of positive emotion is costly and draining to the workers themselves. ${ }^{6}$

Psychologist of organizational behaviour Alicia A. Grandey further expanded Hochschild's definition of emotional labour to describe, "the management or modification of emotions as part of the work role."7 As she argues, "[i]n the past, emotions were ignored in the study of organizational behaviour [.... the workplace was viewed as a rational environment $[\ldots .$.$] emotions were not even considered as$ explanations for workplace phenomenon." " However, workplace labours have a real impact on the workers' well-being; if left unacknowledged, emotional labour could lead to outcomes such as stress and burnout, though if managed with care could assist the worker in achieving a sense of job satisfaction as well. ${ }^{9}$ Grandey's definition helps

\footnotetext{
${ }^{4}$ Arlie Russell Hochschild, The Managed Heart: Commercialization of Human Feeling (Berkeley: University of California Press, 1983), 328.

${ }^{5}$ Hochschild, The Managed Heart, 20.

${ }^{6}$ Hochschild, The Managed Heart, 20.

${ }^{7}$ Alicia A. Grandey, "Emotion Regulation in the Workplace: A New Way to Conceptualize Emotional Labour," Journal of Occupational Health Psychology 5, 1 (2000): 95.

${ }^{8}$ Ibid.

${ }^{9}$ Grandey, "Emotion Regulation in the Workplace," 103-105.
} 
explain why the commemorative workers I interviewed communicated feelings of stress, fatigue, and burnout during and after performing their roles.

Drawing on other scholars such as Wharton and Erikson (1993), Kruml and Geddes (1998), and Timmers, Fischer, and Manstead (1998), Grandey also argues that a gendered analysis is integral to an understanding of emotional labour. ${ }^{10}$ Distilled, the above scholars collectively argue that men and women "have different motives for regulating emotions, in that women are more concerned with getting along, whereas men are more motivated to stay in control and express [...] anger or pride."11 Though I find this observation to be too rigidly categorical, it assists in introducing the roles gender might play in the emotional labour experienced and remembered by my interviewees. ${ }^{12}$

Public history scholars such as Amy Tyson have examined the role of emotional labour in the public history workforce. In her book, The Wages of History, Tyson uses Hochschild's theory and her own participant-observation to explain why some of the interpreters at historic Fort Snelling felt exhaustion after performing their roles. ${ }^{13}$ To avoid an inauthentic performance, these workers invested their own emotions into their

\footnotetext{
${ }^{10}$ A. S. Wharton \& R. J. Erickson, "Managing emotions on the job and at home: Understanding the consequences of multiple emotional roles," Academy of Management Review 18, 3 (1993): 457-486; S. Kruml \& D. Geddes, "Exploring the dimensions of emotional labor: The heart of Hochschild's work," Paper presented at the First Conference of Emotions in Organizational Life, San Diego, CA, 1998; M. Timmers, A.H. Fischer \& A.S.R. Manstead, "Gender motives for regulating emotions," Personality and Social Psychology Bulletin, 24, 9 (1998).

${ }^{11}$ Grandey, "Emotion Regulation in the Workplace," 106.

${ }^{12}$ Though scholars in sociology and psychology continue to debate Hochschild's concept, many of the foundational studies on this subject are now over twenty years old and have penetrated public discussions of labour. See, for example, Sophie Wilkinson, "Why was everyone talking about emotional labour in 2017?" BBC, 2018: https://www.bbc.co.uk/bbcthree/article/5ea9f140-f722-4214-bb57-8b84f9418a7e; Julie Beck, "The Concept Creep of 'Emotional Labor'," The Atlantic, 2018, https://www.theatlantic.com/family/archive/2018/11/arlie-hochschild-housework-isnt-emotionallabor/576637/; Gemma Hartley, “Women aren't nags - we're just fed up: Emotional labor is the unpaid job men still don't understand," Harper's Bazaar 2017, https://www.harpersbazaar.com/culture/features/a12063822/emotional-labor-gender-equality/

${ }^{13}$ Amy Tyson, The Wages of History: Emotional Labour on Public History's Front Lines (Boston:

University of Massachusetts Press, 2013), 98-99.
} 
characters which resulted in changes to their mannerisms, habits, and speech patterns. Once this occurred, there was no discerning the character from the worker and as such, the interpretive roles followed the workers home as they conducted unpaid work off-site to improve their interpretive performances. ${ }^{14}$ Though I analyse a different set of workers whose performances were largely invisible to the public, much of what Tyson observed at Fort Snelling applies here too. Tyson's book brought readers into the changerooms and management offices of the historic site, and into the homes of the workers and considered the emotional labour of these people in ways other historians seldom do. Using this method, Tyson was also able to access the previously hidden racism, hyper-masculinity, and misogyny that occurred behind the scenes. ${ }^{15}$ This approach assists in complicating what is visible to the visitor and adds dimensions to living history sites by humanizing the workers and taking seriously how they feel about the work they do. Tyson's book ultimately shows how integral a study of emotional labour is in public history scholarship. Similarly, this chapter considers both the emotional dimensions and the emotional labour of the commemoration professionals who worked on the centenary of the First World War.

Though there remains a dearth of scholarly literature on the emotional labour of bureaucratic workers, many scholars have written about the emotional labour of tour guides. Jehn-Yih Wong and Chih-Hung Wang, for example, look at a group package tour in Asia and discover that "The tour leader who has frequent, long, and intensive interactions with tour participants and is required to display various emotions plays the

\footnotetext{
${ }^{14}$ Tyson, The Wages of History, 21, 110.

${ }^{15}$ Tyson, The Wages of History, 140.
} 
role of a typical 'emotional laborer' in the tourism context."16 Some of the ways in which tour leaders experience this emotional labour is through filling the role as "entertainer"; there is an expectation that the leader animates the tour participants between locations. They are also expected to manage and solve issues that arise and maintain the tour's quality. ${ }^{17}$ Furthermore, Susan Houge Mackenzie and John H. Kerr explore the psychological impact of emotional labour on adventure guides and conclude that while tour operators are often hedonistic in the fulfilment of their roles, adventure guides experience stress and "intense emotions [.... [contributing] to a generally unpleasant, stressful experience in the work context and provoked feelings of anxiety, frustration, anger, and resentment." ${ }^{18}$ As I explain later in this chapter when I describe the work of the battlefield tour operators I interviewed, much of the emotional labour they experienced during the centenary were akin to what the above tourism scholars describe.

The stories told in this chapter are work stories, but in listening to what these workers had to say about their work, personal elements emerged, exposing a negotiation between the personal and the professional that needs unpacking prior to an analysis of the emotions they exhibited. Linguistic scholars Judy Dyer and Deborah Keller-Cohen examine the ways in which university professors construct professional identity through personal narratives. ${ }^{19}$ Using professors in two different disciplines, they concluded that the professors "exploited the narrative of personal experience as a means of textuallyconstructing their expertise and their professional identities" which "reaffirm their

\footnotetext{
16 Jehn-Yih Wong and Chih-Hung Wang, "Emotional labor of the tour leaders: An exploratory study," Tourism Management 30 (2009): 250.

17 Wong and Wang, "Emotional labor of the tour leaders," 251.

${ }^{18}$ Susan Houge Mackenzie and John H. Kerr, "Stress and emotions at work: An adventure tourism guide's experiences," Tourism Management 36 (2013): 11.

19 Judy Dyer and Deborah Keller-Cohen, "The discursive construction of professional self through narratives of personal experience," Sage Journals 2, 3 (2000): 284.
} 
institutional roles through the frame of personal experience. ${ }^{20}$ My interviewees and I were brought together to discuss their professional involvement in commemorations, and yet many of the stories they chose to tell were often extremely personal and involved discussions of relationships, families, and how they felt about the work they did.

Stress and fatigue were common emotions discussed in interviews with the centennial workers. Given that they were navigating an unpredictable and fluid commemorative assemblage, it is understandable. However, these emotions were a byproduct of the working conditions experienced by these workers in the planning stage of the centenary. In Chapter Three, I explained how the Commemoration Division "surged" people to accommodate the impending large-scale commemorative event. As a result, Sylvie Thibodeau-Sealy explained:

I had six to seven people reporting to me from a management point-of-view and they all had their own individual teams after that. I think it was 160 people all together. I would say that our management team was under an incredible amount of stress, we were fatigued; it is not optimal conditions of work in that short amount of time. Of course, when something would go wrong, on another day on a normal file, that would never have affected them, but given the fact that we were under so much pressure, the slightest thing would get them out of sorts. How often they cried? It was often, like weekly. ${ }^{21}$

Remembering that she assumed her role three months out from the event because of her expertise in project management, the pressure to succeed must have been high. After revealing that "a lot of people had tears and some quit," she elaborated on the unique pressure of the centenary:

The numbers kept creeping up and as did the costs and expectations. So now it wasn't only a one-day event, it was a two-day then it went into a three-day, then it became a week-long. There was something happening all week. Every time you added an event to an already-charged schedule, that increases the pressure in

\footnotetext{
${ }^{20}$ Dyer and Keller-Cohen, "The discursive construction of professional self through narratives of personal experience," 299.

${ }^{21}$ Sylvie Thibodeau-Sealy, interview by Breanna Lester, December 10, 2019.
} 
terms of being able to execute and do it. The Minister's office is responding to Canadians who are writing in and wanting to get on and so they are trying to accommodate that, and the demands from CEF who had a vested interest in this too. They had a large delegation going and had invested a lot of funds and wanted to have an equal voice in a VAC-led event. Managing relationships with very strong personalities was a lot of pressure [.... they had a huge event at the 90th, so there was going to be expectations and an education component. What have Canadians and the world learned from this and how can we now translate that knowledge to what we are going to do now and how do we measure that? It's all fine and good that we do this, but so what? There has to be something that comes out of it, otherwise why do we bother??22

Looking at the short time frame Thibodeau-Sealy and her team were given to execute the Vimy centennial helps clarify some of these emotions. As I explained in Chapter Three, when she began work on the Vimy 100 file, there was a management team, but few supporting staff. To complicate matters, VAC decided to hire an additional manager to assist the pre-existing manager in overseeing the centennial, and the team needed consent from both managers to make any concrete decisions ahead of the event. Christina Gaudet expanded: "Our senior management would not approve things or make decisions until he [the new senior manager] was appointed. Until he came in late September or early October [2016], there was very little decision for a humongous event."23 As was explained in Chapter Three, given the sheer amount of work involved in planning the Vimy 100 ceremony, six months was hardly enough time.

Thibodeau-Sealy took on the responsibility of maintaining working relationships with this new manager and the other staff members. This proved to be one of the most difficult parts of her job. She clarified:

I certainly didn't feel very supported by[management] at the time. That was the most challenging by far. [The new manager], being out of the military, approached this from a very military point-of-view, so he was going on a mission and that's how he tackled it, and there are a lot of positives to that

\footnotetext{
${ }^{22}$ Ibid.

${ }^{23}$ Christina Gaudet, interview by Breanna Lester, January 22, 2020.
} 
because the military is obviously very efficient, they carry through, they'll bulldoze over anybody to get it done, so this was going to happen no matter what. But we were dealing with civilians here who have families and who were mostly women on the management team except for maybe two men and that militant approach did not go well with them, so there was a lot of me massaging relationships because he was very harsh and direct and used hard language which would have been fine in the military, but that approach in a Public Service, not so much. ${ }^{24}$

The new manager had a militaristic and even masculine way of leading that was not received well by the female team members. This seems to have added additional stress to an already stressful work environment ahead of the Vimy centennial. Thibodeau-Sealy also referenced a lack of support. Without a supported work environment, morale decreased and in a high-pressure environment, emotions ran high.

The volume of work also took a toll on Peter Mills. When asked about his personal challenges, he said: "Just the sheer volume of work. My days were all long. They started exceptionally early, and they ended late and that is on the ground in Canada because you're dealing with time differences with individuals you're working with overseas. ${ }^{25}$ Referencing his stress levels after the constant travel his work required, he commented: "The battle rhythm you go through ... it's intense. There's a need to make swift decisions that can sometimes have cost or other implications, to brief senior individuals on issues that are complex on short turn-around [....] Building the plan, following the plan, and keeping the plan up to date as it changes on a daily or weekly basis - very stressful. ${ }^{26}$ There was little margin for error in what Mills described, and yet there was immense pressure to perform here that had an impact on how the workers felt when it was all over. Mills also referred to a fluctuating "plan" which in essence alludes

\footnotetext{
${ }^{24}$ Sylvie Thibodeau-Sealy, interview by Breanna Lester, December 10, 2019.

${ }^{25}$ Peter Mills, interview by Breanna Lester, November 20, 2019.

${ }^{26}$ Ibid.
} 
to the unstable commemorative assemblages he found himself navigating during the centenary. The comments of the VAC workers I quote here accentuate the alreadystressful conditions they endured even before the events rolled out. These workers were tired from working long hours, travelling constantly, and taking on responsibilities out of the scope of their job descriptions including managing the relationships of senior management to obtain the approvals needed to facilitate a successful event. These were the emotional conditions in place prior to the events themselves and only added to these workers' labour as they piloted through the centenary program.

As preceding pages have shown, there was a great deal of stress placed on the commemoration planners as they navigated their difficult work environments prior to the execution of the events. However, the events themselves compounded their emotional labour. Sylvie Thibodeau-Sealy shared a powerful story with me about Vimy 100. She said:

We had people cursing and some people were spitting. There were guides that left because there was crying. It was a very difficult crowd-control situation [.... So, there were barricades that were pushed down and people rushed the monument. Nobody got hurt or lost, but the potential for that was quite high, and I think the people who were on the ground and trying to help obviously got very frustrated and couldn't stand being there another second. They felt very violated in terms of words. Nobody touched anybody, but it was difficult for a lot of people. $^{27}$

Though the issue of crowd control was addressed earlier in this dissertation, this quote emphasises the emotional fallout of what transpired. She continued:

Who helped us with crowd control? Anybody who had a VAC identity, so that included the tour guides who are students. A lot of them told me they couldn't do it anymore. I told them that I appreciated them coming out, but that they had no obligation to stay. If you can't do it, you can't do it. Go. I can't have anybody break down. They stayed for as long as they could, but several left. We had a lot of volunteers, and them too, after a while, they left. So, there was a very small

\footnotetext{
${ }^{27}$ Peter Mills, interview by Breanna Lester, November 20, 2019.
} 
group of people who were there to manage a rather large crowd who were anxious to leave. ${ }^{28}$

Even though crowd control was not part of anyone's job description, as representatives of VAC and the Canadian public writ large, Thibodeau-Sealy, her staff, and the tour guides had to maintain composure for as long as they could stand before it became too much. Though it appears that Thibodeau-Sealy did an exceptional job navigating these stressful circumstances given that none of this chaos was captured on television, the emotional impact was immense. In place of what was supposed to be a personal commemorative moment for Thibodeau-Sealy, she instead recalled:

I was on the ground and was the last one off the site and I remember walking the site and I remember looking at the monument and I remember seeing a huge crowd on the monument and that was never part of the plan to exit the site by going over the monument because that is disrespectful and that was never what the intention was, but because of the mix-up of the transportation, the buses were just not coming quickly enough and individuals were tired of waiting and they had enough and they pushed the barricades down and rushed. ${ }^{29}$

Though, as Thibodeau-Sealy also said, none of this was captured on camera and that boded well for critics and others tuning in over one of the many broadcasting services, it affected her deeply, both professionally and personally. ${ }^{30}$ As a manager, it was important for her not to exhibit emotion in the midst of the confusion on site, because it may have caused those around her to panic more so than they already had. Nonetheless, the working conditions expressed above appear conducive to stress. Crowd control was not in the VAC planners' job descriptions, neither was protecting the monument, or being spat on by civilian commemorators, and yet this was the work environment ThibodeauSealy and her team found themselves navigating on April 9, 2017. Under such

\footnotetext{
${ }^{28} \mathrm{Ibid}$.

${ }^{29}$ Sylvie Thibodeau-Sealy, interview by Breanna Lester, December 10, 2019.

${ }^{30}$ Ibid.
} 
circumstances, it is no wonder so many paid and voluntary personnel abandoned their

posts on that day.

As was teased out in this chapter's epigraph, Christina Gaudet also faced personal challenges with the centenary planning. Her rationale for transitioning out of her role after twenty-odd years in the Commemorations Division was telling. Gaudet said:

For the 2017 cycle, I was away in Europe for a week or ten days minimum every month from October [2016] ... then I was away for twenty-seven days I think for delivery of the event, and get home after this exhausting four hours sleep over four days, then I was home for less time than I had been away for to deliver Vimy before I was packing my suitcase again to go back to deliver a[n event] for Passchendaele. I was very stressed about that, about leaving again so quickly. Not even giving my family ... we were home about three weeks ... so I was very stressed about that and not even giving my family the best of me because I was so exhausted. You do the "sleep as much as you could and then try to keep up with them" but I got to Ypres and on the second night I was in Ypres, my cell phone ... I was trying to sleep and the time difference and everything, so I put my cellphone in the bedside drawer in hopes that ... I keep it on just for emergencies. I heard it going off and I thought my mother and sister were having a conversation on text. When I looked at my phone to turn it off, my eight-year-old son had fallen out of a tree, broke his arm, hit his head, and was on his way to surgery. I couldn't even get there that day. I got to Brussels that day and was unable to get a flight back to Canada; I had just missed the flight by forty-five minutes, and I spent that night in a Brussels hotel at the airport saying "what the heck is wrong with me?" So, I came home to my son who had his elbow pinned and is in a cast. These are tough choices, but when you choose to have children, "you need to do better than you're doing, Christina." I had a boss at that time where it's like "if you go home, you're done." I had to choose my child. It was a very difficult time because he wanted somebody who was committed to being there every single time and we talked about changing roles, but the environment where those are the choices, I just decided it was better for me and my family just to decide not to go overseas and do that anymore. ${ }^{31}$

Gaudet's narrative encapsulates many emotions; she experienced the stress of leaving her family for weeks on end, especially the existential crisis she suffered in Belgium when she was unable to swiftly return home to tend to her injured son, and the difficult decision she had to make to leave a role that defined her for many years. In this case, she had to

\footnotetext{
${ }^{31}$ Christina Gaudet, interview by Breanna Lester, January 22, 2020.
} 
choose between her role as mother and a worker, and though I am sure she did not regret the decision she made in the end, it was an impossible situation to have to navigate. Gaudet's emotionally challenging moment also became emotional labour when she needed to confront her superior once she had made her decision. She should not have had to choose between her work and her family.

Christina Gaudet's story also adds another dimension of analysis previously unexplored: the impact of work on the family. Sylvie Thibodeau-Sealy shared a similar story of this impact. At the conclusion of our interview, Sylvie shared that:

From a personal point-of-view, if you are awake, you're working. Even if it is your supper, or lunch, doesn't matter. You are planning, thinking, responding, doing whatever. You can do that for so long, but eventually it does catch up to you and so the personal cost of that is on your family. I missed my daughter's sixteenth birthday, I missed my wedding anniversary, these things to the cost of needing to be overseas and although your family members will understand, there is a strain there cause after a while, after doing this once, twice, three times because I was doing this once a month for maybe nine months. It gets to be a bit much. $^{32}$

In Tyson's The Wages of History, she writes of her own self that she noticed a shift in mannerisms, speech patterns, and habits changed, even after she "clocked out." ${ }^{" 33}$ From their stories, it appears Christina Gaudet and Sylvie Thibodeau-Sealy experienced a similar intrusion of work into their personal lives. Each of these women felt guilty for missing some of the most important milestones of their family members while off planning and attending commemorative events. Though they were both performing work duties, neither was able to clock out at 5 p.m., go home, and give their families their undivided attention. Their stories also reveal an interesting gendered component to this kind of work; both women chose to share how their work impacted their family without

\footnotetext{
${ }^{32}$ Sylvie Thibodeau-Sealy, interview by Breanna Lester, December 10, 2019.

${ }^{33}$ Tyson, The Wages of History, 110.
} 
prompt, and though I do not doubt that Robert Löken and Peter Mills' families felt the impact of their work as well, they chose not to tell familial stories. Nonetheless, the immense pressure placed on the VAC workers, coupled with strenuous working conditions causing stress and fatigue, led to eventual burnout.

The prolonged stress my VAC interviewees suffered led to exhaustion. Christina Gaudet explained:

During Vimy, for instance, there was too much too close together (and I was part of that planning team), but we tried to make an adjustment later on and it wasn't accepted [....] Literally that whole weekend from Friday morning at six till Sunday night at eleven, I slept not more than four hours. That is a really tough thing to recover from after months of constant demands and constant information and changes and just sheer volume. The personal does take its toll and people burn out and some are more resilient than others. I'm resilient; I've been in and out of events since literally the early 2000s and I think I may have seen my last event that I'm going to manage. It's a big burn out and it's really hard on my family. My kids were younger at Vimy; they were okay, but now I have a teenage daughter and she has some of her own challenges. Now I have to choose to be a mother because I can't do that job and be the mother that I want to be. ${ }^{34}$

Gaudet pointed to flaws in the planning phase when she discussed how the Vimy 100 events were planned in tight succession. And after months of adapting to the needs of her role, she found herself burnt out. But, Gaudet's job did not only affect her, it also had a profound impact on her family and, in the end, Gaudet, in her words, chose to be a mother. Peter Mills was more explicit in his decision to change careers. As he concluded in our interview, "I loved the work I did, but I was tired and sadly you get more and more tired and jaded, so it's good to have a change." 35 Though he was not particularly animated when he shared this with me, the effects of the pressure, stress, and eventual burnout he felt while working on the centenary were noticeable.

\footnotetext{
${ }^{34}$ Christina Gaudet, interview by Breanna Lester, January 22, 2020.
}

${ }^{35}$ Peter Mills, interview by Breanna Lester, November 20, 2019. 
Sylvie Thibodeau-Sealy described an institutional burnout in our interview. She said: "The cost for over time for this was astronomical; some people made $\$ 40000-50$ 000 worth of overtime. That's half of their salaries. That means the rest of the department couldn't hire. That's the fatigue: we too have priorities, we too have things to do and we are bound, but not being able to move forward if you are eating all the resources up. That certainly is a message I have heard more than once." ${ }^{36}$ That is an incredible amount of overtime, and an incredible drain on a department whose budget for the centenary was low to begin with. Though Thibodeau-Sealy was the only one of my interviewees to describe fatigue in this way, others described this collective drain as "commemoration fatigue."

The first time I heard the phrase "commemoration fatigue" was during my interview with Tim Cook. In discussing the commemorations at Gallipoli, Cook remarked, "Of course, the Australians pour tens of hundreds of millions into their commemoration to the point where when I visited there in 2016, there was a talk of commemoration fatigue: that people were tired of it, they'd done too much.."37 However, when asked if he thought commemoration fatigue happened in the Canadian context, he stated, "We certainly didn't do enough [....] Well we didn’t [experience fatigue] because we simply didn’t do enough to get fatigued from it. ${ }^{\prime 38}$ However, CIRNAC historian JeanPierre Morin had a different, contrary perspective:

To say there was commemoration fatigue amongst Canadians, sure, no argument. The fact that there was commemoration fatigue amongst federal departments, definitely because this took over our lives. I worked on commemorations for five years straight. That's basically all I got to do. Even though it was fun, it was extremely frustrating. I led two national

\footnotetext{
${ }^{36}$ Sylvie Thibodeau-Sealy, interview by Breanna Lester, December 10, 2019.

${ }^{37}$ Tim Cook, interview by Breanna Lester, May 30, 2019.

${ }^{38}$ Ibid.
} 
commemorations: Indigenous commemorations of the War of 1812 and the Canadian Arctic Expedition from 2013-2015, so there were always overlaps. So, those were my commemorations which meant I wasn't doing anything else. ${ }^{39}$

When told Cook's remark about Canada not doing enough to get fatigued, Morin remarked:

The [Canadian War Museum] was sheltered from that because people expected the War Museum to have commemoration. They didn't expect your average Joe Canadian to constantly be engaged. When you go to the War Museum, you are engaged because you are going to the War Museum, so if you are going to a travelling exhibit, you are going there because you want to [....] I think it is about fatigue because we didn't know what we were commemorating anymore. We were always commemorating something. The Prime Minister was always at something, unveiling something with some old soldiers or people dressed up like old soldiers. ${ }^{40}$

The conflicting perspectives of Cook and Morin are good examples of the variety of experiences two commemoration professionals can have depending on their place within the various assemblages. Morin experienced a constant stream of commemorative activities in addition to his professional work, whereas Cook's job was to provide educational and commemorative programming for the public year-round regardless of whether it is an anniversary year or not. As a museum professional who is expected to deliver commemorative programming and engage with the public, it is also possible that Cook was able to take on more emotional labour than Morin whose regular job is not commemorative in nature. Morin's perspective also shows that taking on more than one commemorative assemblage at a time is a direct cause of fatigue because he "wasn't sure what [they, the Government of Canada] were commemorating anymore.” Perhaps the structure of the Road to 2017 was always going to produce commemoration fatigue because it involved the stringing together of many assemblages that, as I showed in

${ }^{39}$ Jean-Pierre Morin, interview by Breanna Lester, July 5, 2019.

${ }^{40}$ Ibid. 
earlier chapters, many of the VAC workers navigated simultaneously throughout the 2012-2020 period.

In our interview, Morin also indicated that the public servants working on the Road to 2017 were fatigued before the First World War centennial even started because so many resources (departmental, physical, and emotional) had already been spent on the 1812 bicentennial. He stated:

We were talking about it at the committee level [referring to the Interdepartmental Commemorations Committee] about how fatigue was setting in amongst the people who had to be there. There was growing discomfort amongst DND from my perspective as I look at them on how the commemoration should involve the Canadian Armed Forces. Soldiers didn't want to do it, the commanders didn't want to do it, and they definitely didn't have the money to pay for it. So, how would they even be able to do this at a time when the Conservative government is slashing budgets, demanding the commemorations, but not providing any kind of funding at all ? $^{41}$

As explained earlier, the Conservative government spent an immense amount of the commemorative budget on the War of 1812 commemorations which left a comparatively small remainder for the entire First World War centenary. Fatigue was widespread prior to the centenary's commencement, and it only worsened as the events unfolded.

When asked about commemoration fatigue, Canadian Battlefields Foundation employee, Jérémie LeBlanc (in discussing D-Day commemorations) added a personal perspective:

Do you think I wanted to take part in the seventieth? Commemoration fatigue for me ... I enjoy the Foundation ceremonies because they're smaller and more humble. When you go to these large ceremonies ... the security and everything else. That's fatiguing. I knew my feelings before going to this. You'll see the other tour leaders standing far away from it. You get fatigued about it and you don't care what's going on in the tour because it's too much. ${ }^{42}$

41 Jean-Pierre Morin, interview by Breanna Lester, July 5, 2019.

42 Jérémie LeBlanc, interview by Breanna Lester, August 27, 2019. 
Douglas Ballam also shared his thoughts on commemoration fatigue. In our interview, he stated:

I was mostly involved in administrating grants, but I suppose there was a conference a year or so. As a reservist with the RNR [Royal Newfoundland Regiment], it was day and night. It was pretty constant for me. In terms of commemoration fatigue, yeah totally. First of all, I'll answer personally. I didn't have much difficulty dealing with the First World War day in and day out for five years. Not really. It affects me more so on the pilgrimages. I remember in 1998 and 2001, you are wrung out. Most everyone was weeping at these ceremonies, so to me commemorative fatigue, that's what I think about when I think commemorative fatigue; memorial ceremony after memorial ceremony, three a day, being totally emotionally drained. I didn't find institutionally ... well, there was some at [Memorial] University. I remember people saying 'Jeeze, that program is still going on?' That sort of thing. The provincial government's program was intended to be like the University's where they had a five-year grant program, but they didn't. They did it for two years and then they stopped. It just kind of waned. I was also involved in the city of St. John's committee and their work. We worked quite hard; we had public meetings and surveys on what the citizens of St. John's wanted to do. ${ }^{43}$

Ballam speaks to both an institutional commemoration fatigue, and a personal one.

However, his personal commemoration fatigue was different from LeBlanc's. LeBlanc's

fatigue was caused more by the crowds of commemorators rather than the emotional commemoration fatigue Ballam described. Both LeBlanc and Ballam's roles are more akin to the emotionally labourious jobs of Hochschild's flight attendants and Tyson's historical interpreters because a large part of their job is in direct contact with publics. ${ }^{44}$ As battlefield tour operators, their job is to manage the tour and ensure clients are happy and attended to. This means the operator must remain calm and sharp to remain in control of the tour because, as discussed in Chapters Two and Three, they budget time to visit many sites and one moment could throw off the entire tour. Ballam's position is interesting because he is both an administrator for Memorial University and a Reservist

${ }^{43}$ Douglas Ballam, interview by Breanna Lester, July 17, 2019.

${ }^{44}$ Hochschild, The Managed Heart, 20; Tyson, The Wages of History, 5. 
in the Royal Newfoundland Regiment. As he indicated in our interview, he felt two kinds of fatigue, one institutional and the other personal. As a Reservist who took part in many commemorative ceremonies, he had to maintain a militaristic composure, and showing emotion was not an option. And, as an administrator during an incredibly busy commemorative period, he needed to perform his tasks in a timely manner which required a certain amount of alertness. There was emotional labour in that as well.

Caitlin Bailey communicated similar sentiments when she described commemorations as “draining." Referring to her foundation's calendar of events, she commented that "As an organization, for people at VAC, army regiments, all of us. By November $12^{\text {th }}$ as all sort of pale and hollow-eyed. It's our season. Like college basketball or something, you know?"45 This "pale and hollow-eyed" expression Bailey described is perhaps indicative of the emotional component of their commemorative labour; they invest so much into their work to ensure a successful commemoration. Bailey's comparison to professional sports is also telling; they work for what is in a regular year, one day, meaning that most of their other workdays are spent preparing for a one-day event. For Bailey and the Vimy Foundation, the centenary added April 9 to their workload, thus increasing it twofold. She also made the point that commemorations are "ephemeral as well. It's not like writing a book and the book is going to be there forever. It is investing hundreds of thousands of dollars and hundreds of thousands of man hours in an event that does not last. Vimy 100, for example, was three days." ${ }^{" 46}$ There is a certain amount of hopelessness in Bailey's comments on the fleeting nature of the events that dictate these workers' lives for so long. This again refers back to the importance of

${ }^{45}$ Caitlin Bailey, interview by Breanna Lester, July 24, 2019.

${ }^{46}$ Ibid. 
logistics discussed throughout the previous chapters; commemorative planners can work tirelessly to a point, but if the logistics are not sound and the workers tire, the event suffers, and criticisms are levied.

But what impact has this fatigue or exhaustion had on the ways in which these workers experience commemoration themselves? Whether it is due to the stress and fatigue associated with her duties as Executive Director of the Vimy Foundation or because of personal choice, Caitlin Bailey shared:

I personally as an individual (not a professional) now do not attend public commemorative events because I actually don't like them. I find the crowds distracting and the logistics around it I find often are poorly run, and I don't do a lot of thinking about what's going on and feeling that emotional connection when I'm in these massive events. So, for me, if I'm not on the job and I'm commemorating privately, everything I do is in quiet and by myself when there are no other people around or very few other people. So, I'm the person who visits the cenotaph in July and puts something down then because that is my moment where I as an individual am looking at it and saying "I remember this, I am aware of this, and I think about these people and what they lived through or didn't live through, and what they gave up." And so for me, it is a very private thing and entirely divorced from my public activities as a commemoration professional. As a professional, I go to every commemorative ceremony you could possibly think of. In terms of private activities, I see a very big space between public and private. ${ }^{47}$

Bailey's comment highlights the distinction between performing an emotionally labourious role as a commemorative professional, and the kinds of emotions she allows herself to feel in private. As a professional, Bailey's focus is on the logistics of the day and the crowds, but alone, she is able to feel affected by her surroundings and commemorate in her own way, thus exposing the tension between the private self and professional self.

${ }^{47}$ Caitlin Bailey, interview by Breanna Lester, July 24, 2019. 
The above discussion of commemoration fatigue has referenced the emotions of workers performing commemorative roles outside government. It is important to acknowledge that, while these workers were not at the helm of the large national commemorations at the centre of this dissertation, they too handled incredible amounts of stress and felt fatigued. The battlefield tour operators I interviewed communicated a similar fatigue to what Ballam mentioned. Field of Fire Tours proprietor, David Patterson stated:

The original tours were twenty-one or twenty-two days long. It is very demanding. The First World War is much more emotional people because of the scale and the size, so it is much more impactful than the Second World War. The Second World War is more intellectually stimulating for people. The First World War is more about the personal. You can see nine cemeteries from the Beaumont-Hamel park. So, I've found people on the two-week trips can get emotional by the end. We try and give them a day off. There's a certain amount of battle fatigue and cemetery fatigue, so you have to judge that in the group sometimes. ${ }^{48}$

Patterson tries to capture the immensity of the First World War in his tours which is often emotional for his clients. Liberation Tours' John Cannon and Phil Craig said something similar, though in a less direct way. Speaking about their clientele, Craig stated: "We're dealing with a lot of pride here. We are very proud of what our boys have done and that becomes the driving force behind driving through the sadness and tears and fatigue you feel. ${ }^{49}$ To mitigate the fatigue, Cannon and Craig integrated trivia and music into the experience on the coach between site visits. It is part of their jobs as battlefield tour operators to navigate the emotions of their participants on every trip they take and whether it is building in a day off or breaking up the site visits with trivia and music, managing emotions is part of the commemorative experience. However, neither Patterson

${ }^{48}$ David Patterson, interview by Breanna Lester, September 3, 2019.

49 John Cannon and Phil Craig, interview by Breanna Lester, August 13, 2019. 
nor Cannon and Craig discussed their own emotions as it related to their tours. This is perhaps because when they take groups on tours, it is a performative act. Part of the tour operators' emotional labour is to remain emotionally stable to ensure their clients feel comfortable and supported.

However, Cannon and Craig were not shy in describing their frustrations with VAC during the centenary. Some of this was shared in Chapter Four, though it is worth noting here that their frustration was a direct result of VAC's lack of communication before the event or an attempt to understand how their industry operated. Aside from their comments that everything VAC does is a "fucking shit show," They deduced that "VAC has no conduit of communications with the travel industry that is bringing the people to the event $[\ldots .$.$] Their website isn't functional, not updated, and no one to get on$ the phone with, and most of the communication you get back starts with 'I'm sorry' [....] We're desperate because we have a coach of people who have paid six to seven thousand dollars and we are telling people a day or two before what is going to happen." ${ }^{50}$ Liberation Tours' frustrations caused by VAC contributed to a great deal of stress on both sides. As was discussed in previous chapters, VAC had to follow the rules of the French government, were pressed for time, and on the day of had to contend with a myriad of issues with malfunctioning toilets and security. Battlefield tour groups were likely far down the list of priorities. However, from the battlefield tour perspective, they had entire groups of people, most of them elderly, lying in wait for specific instructions that were not available to them because of a lack of communication from VAC. To say that Vimy 100 was stressful on both sides of this equation is an understatement. Cannon

\footnotetext{
${ }^{50}$ John Cannon and Phil Craig, interview by Breanna Lester, August 13, 2019.
} 
and Craig's experience is almost identical to what Mackenzie and Kerr observed in their interactions with adventure tour guides; Cannon and Craig experienced frustration, anger, and resentment towards VAC for compromising the quality of the tours Cannon and Craig researched and rehearsed for years beforehand. ${ }^{51}$

Despite all this stress and fatigue, the workers discussed above had to continue in their roles, no matter what. For VAC and the Vimy Foundation, April 9 was their day, and they had to work tirelessly to ensure that what was captured on camera was flawlessly executed. As Gaudet's story about her son showed, it was expected that the professional come before the personal, at least until the big events were over, unless there was another event to plan simultaneously (as there often was). And for battlefield tour operators, they only make money if people are interested in and enjoy their tours. This means that operators like Patterson and Cannon and Craig must work long hours in the years leading up to their tours to ensure repeat customers and positive referrals. Consequently, Cannon and Craig's frustrations came from a place of great passion for their work, but also because despite all of their labours ahead of Vimy 100, they had no control over and yet remained completely financially invested in the logistical components of the event.

\section{In Service to the Public}

When stepping into a professional role, the expectation is that you represent the organization for which you work. Given that six of my interviewees are federal public servants, this concept is important because they not only represent an institution, but also

\footnotetext{
${ }^{51}$ Mackenzie and Kerr, "Stress and emotions at work," 11.
} 
the Canadian public. This came out in the interviews, either through a reluctance or hesitance to discuss certain topics, or a verbal acknowledgement of something they perceived as more important than the personal self. For example, in response to critiques centred on the perceived lack of planning that went into the centenary commemorative events, previous VAC employee Peter Mills stated that "no one knows about it because at the end of the day, we don't want anyone to know about it because what it's really about is the memory of those individuals and the experience of those who are there to remember them." ${ }^{52}$ Mills prioritised the memory of the dead over his own feelings as a worker. His former colleague, Robert Löken, shared similar sentiments. While discussing the Vimy critiques, Löken commented that "the downside to that is the people whom this is really about (the veterans), that gets lost in the broader story of what went wrong." ${ }^{53}$ Mills felt deeply about the Beaumont-Hamel event, "Because [he] owned it, because it was [his], [he] felt a bit more personally about it, so [he] was a little more frustrated with some of the responses and frustrated by how people politicize these things. ${ }^{\prime 54}$ For Löken, he had spent a large part of his career with VAC connecting with veterans through maintaining communication to invite them to events, and so he tried to keep the focus on them as much as possible. Though they tried and remain altruistic, they were also emotional, and both were affected by the criticisms their department received.

Despite the emotional and bodily hardships, mental strain, fatigue, and burnout the workers experienced, they retained affection for their individual occupations. When

\footnotetext{
${ }^{52}$ Peter Mills, interview by Breanna Lester, November 20, 2019.

${ }^{53}$ Robert Löken, interview by Breanna Lester, November 20, 2019.

${ }^{54}$ Peter Mills, interview by Breanna Lester, November 20, 2019.
} 
asked about pride in his accomplishments during the centenary, Mills explained that at

Beaumont-Hamel:

We had lots of good historic linkages. We had a small Innu boy read the Act of Commitment in Inuktitut and we also included a piece about an Innu sharpshooter/sniper from Labrador for example which is not one of these pieces of history people would know much about. The fact that we included some really nice pieces of music in that program. I was very proud of that ceremony. I was very proud that the French newspaper in the region had ... they were at Thiepval ... they came then to our ceremony at Beaumont-Hamel which was smaller and more intimate and said 'this is commemoration done right; the way commemoration should be.' So, while there were some parties from Newfoundland that clearly weren't happy, the French who see a lot of these things and live in the same community where the site is felt that it was a beautiful, touching ceremony. ${ }^{55}$

Most all my interviewees could point to a moment or event they participated in as a professional that gave them a sense of pride or accomplishment. For example, Caitlin Bailey was proud to have been the Keynote Speaker at the City of Montreal's

Remembrance Day ceremony on November 11, 2018. She recalled:

I was five years into my career, thirty-one years-old, and I was invited to be the keynote voice of that last ceremony of the centenary. So, it was in front of 25000 people, and I was able to speak about a theme that's really important to me and that underlines all of the work that I have done [...] which is to underline the human cost of war and how detrimental war is to people. ${ }^{56}$

Referring to their chosen careers as battlefield tour operators, Liberation Tours' Phil

Craig stated that "Yes, these are commemorative tours, but they're theatre storytelling.

There is a larger story and a smaller scene story, and the goal is to sew them together into an experience that someone will never forget. And that's what we do."57 It is clear from this statement - and from speaking with both Craig and his Co-Director, John Cannon that they love what they do and have great pride in the service they provide.

\footnotetext{
55 Peter Mills, interview by Breanna Lester, November 20, 2019.

${ }^{56}$ Caitlin Bailey, interview by Breanna Lester, July 24, 2019.

57 John Cannon and Phil Craig, interview by Breanna Lester, August 13, 2019.
} 
Christina Gaudet also expressed pride in our conversation. When asked about some of the highlights of her twenty-year tenure in commemorative events management at VAC, she expressed that she was proud to have seen the visitor's centre at Vimy Ridge built as she said it was a "five-year labour of love," though her truest accomplishment was the innovative work she conducted during the centenary. ${ }^{58}$ She said,

As much as I love Vimy ... and it will always be a part of me, I'd probably have to say the opportunity to innovate on my 2018 projects [referring to a moon garden and sculpture project] because they are unique from each other, but the conversations that the art and the moon garden opened up, I really think we are on the road to doing what we want to do which is talk to new people and get new people involved. They're small budget items but engage cross-generationally. ${ }^{59}$

Gaudet's pride was obvious in our interview perhaps because, as was quoted in the epigraph of this chapter, she truly loved her work.

As with many chosen careers, there is a certain amount of personal fulfilment that goes along with the roles one occupies in the commemoration industry. It was obvious in interviewing Tim Cook that he felt a great deal of fulfilment in what he has accomplished as an historian working for the Canadian War Museum. In reference to his role as CBC guest co-anchor at Vimy 100 , Cook remarked that it "was very gratifying to see people at Vimy holding my book. It was also interesting that I had published articles in Legion Magazine and Canada's History, and people had those as well." ${ }^{90}$ Cook is understandably proud of the work he has done throughout his professional career as both an academic and commemoration professional. Jean-Pierre Morin was able to identify a niche within his department through his commemorative work. In discussing the War of 1812 commemorations, he stated:

\footnotetext{
${ }^{58}$ Christina Gaudet, interview by Breanna Lester, January 22, 2020.

${ }^{59} \mathrm{Ibid}$.

${ }^{60} \mathrm{Ibid}$.
} 
I spent a lot of time working on a file which doesn't go anywhere [...] and it was a very frustrating file, so there is a certain amount of accomplishment there, but because of the difficulty on the file, it has made me very knowledgeable about the Department [CIRNAC]; it's created a world in which I am the go-to answer person. You have to come to me if you need these answers [....] It's like you control the information, and as an historian, it's always an awesome thing. ${ }^{61}$

Creating a niche for oneself in any job is an accomplishment; as a knowledge worker, Morin felt fulfilled in his role.

John Cannon and Phil Craig's careers as battlefield tour operators began seemingly by accident, but in speaking with them, it was obvious that they are grateful for and are personally fulfilled by their work. At the start of my interview with them, Craig described how they got started. He said they would tell people at their museum in Keswick, Ontario that they were "going over to do some battlefield bashing which is something John and I love doing." ${ }^{62}$ Since then, Cannon and Craig have built a career out of doing what they love which must contribute to their personal senses of gratification as individuals working in the commemoration industry.

I also noticed that personal challenges often interacted with these professionals' perceived duty to commemorate Canada's war experience. After he provided insight into how stressful his job was at times, Peter Mills clarified,

Would I change it for the world? No. I had an incredible experience. I loved that work. It's extremely important that Canada does this kind of work, that Canadians are encouraged to remember the service and sacrifice of those who've been in the CAF [Canadian Armed Forces], and in particular, to remember just what a horrible thing it was and how we should do our utmost to never have something like that happen again. ${ }^{63}$

\footnotetext{
${ }^{61}$ Jean-Pierre Morin, interview by Breanna Lester, July 5, 2019.

${ }^{62}$ John Cannon and Phil Craig, interview by Breanna Lester, August 13, 2019.

${ }^{63}$ Peter Mills, interview by Breanna Lester, November 20, 2019.
} 
Mills perceived himself to be part of something greater than himself and found personal fulfilment in that. Despite her decision to transition out of her role, Christina Gaudet also shared kind words about her colleagues at VAC. She said: "I've loved this work. I've loved the people that I've met doing this work whether they're family members, descendants, veterans, like-minded people who really feel the emotion of what it is to be Canadian and what our service people did for us and the world." ${ }^{64}$ There is some of the memory preservation, identity rhetoric in here that I referenced in the introduction of this dissertation that is ingrained in these workers which aided them in finding fulfilment in their work; they see commemoration as their duty because the preservation of the memory of soldiers is important and necessary.

Out of all the long nights, exhaustion, stress and fatigue rose something Sylvie Thibodeau-Sealy characterized as "special" that she could share with her colleagues who also went through it. She said:

When you're going through difficult work situations, the people that you surround yourself with become your support and we have become quite close, so that's a positive out of all of this. There are some negatives, of course, but there's also the positive side where I can say that when I cross paths with someone I was at Vimy with today, we smile at each other and we know that we had this one thing in common that we will always share together. It's a bonding thing and we will always have that; little inside jokes or things that had happened that only us would understand because we lived it. That's kinda special too. ${ }^{65}$

Having support at work in the form of colleagues who understand the trials and tribulations of the job is extraordinarily helpful and even required in the high stress situations my interviewees discussed in this chapter. Though the working conditions described in the previous sections are far from optimal and require further inquiry, they

${ }^{64}$ Christina Gaudet, interview by Breanna Lester, January 22, 2020.

${ }^{65}$ Sylvie Thibodeau-Sealy, interview by Breanna Lester, December 10, 2019. 
did create a unique environment in which personal growth, fulfilment, and lasting friendships were formed. Christina Gaudet added a pithy comment to the end of our interview when she said commemoration is "kind of a vocation; it gets you, commemoration does." ${ }^{66}$ Her statement perfectly encapsulates the emotional labour of commemorative work.

\section{Conclusion}

The stories shared with me show that commemorative workplaces are emotionally complex and challenging environments. Especially in high-pressure situations such as in the midst of a televised, international commemorative period such as the First World War centennial, emotions are paramount. The centennial workers endured unfavourable working conditions including long hours, strenuous travel, external pressures, tight deadlines, and on top of that, often took on tasks that were not in their job descriptions and had to find a balance between personal, familial, and professional duties. And on occasion, the emotional implications of their labour turned into emotional labour as they interacted with coworkers and various publics. However, despite their difficulties, these workers managed to find joy in and were also positively impacted by their performances, even though, like with Peter Mills and Christina Gaudet, it led to making the difficult decision to transition out.

For their part, battlefield tour operators engaged with the public in a face-to-face capacity more often than the public servants, and this emotional labour was affected by VAC's decisions. The operators are invested in and also rely upon financially on their

${ }^{66} \mathrm{Ibid}$. 
customers being satisfied with their own commemorative tourist experiences, and the frustration they shared with me about VAC was focussed on those things, big and small, that impeded battlefield tour operators' ability to perform their emotional labour. Indeed, on both the frontline and behind the scenes, emotions play a powerful role in these workers' experiences.

Commemoration is an unpredictable, fluid assemblage comprised of many moving parts. Reconceptualising commemoration in this way aids in an understanding of its instability and this in turn helps explain why my interviewees were incredibly stressed, fatigued, and burnt out as a result of their labours. The concluding chapter that follows will look at some of the lessons these commemorative workers learned after the centenary as a result of the negative press and emotional labour they endured and will offer new working definitions of what commemoration is given the perspectives I gleaned from the ATIP records, my conversations with commemorative professionals, and my own experiences. 


\section{Chapter Six: Conclusion}

Remembrance Day is arguably as significant a date on the calendar in English Canada as Easter or Thanksgiving. For many, it dictates when Christmas lights and decorations can go up (not before November 11), there are always special ceremonies at sporting events, the federal government has a day off, and children attend special Remembrance Day ceremonies in their schools. Growing up in southern Ontario, I memorized John McCrae's In Flanders Fields to recite at that assembly, and I remember winning an art contest through my local legion for a painting inspired by McCrae's poem. And my Grade Eleven history teacher scolded students for wearing poppies anywhere but on the left side of their shirt, above their hearts. Lest We Forget, Lest We Forget.

As this dissertation has shown, commemoration is important to many people, especially those who work incredibly hard to produce them. With that in mind, I asked my interviewees, as a final question, how they conceptualized "commemoration." Peter Mills said: "It means respect, so taking a little bit of time to pause and to remember and to reflect on the experience and sacrifice of someone who has gone before you who might not have had the opportunity you do as a result of their experience." Sylvie ThibodeauSealy remarked: "I think it's the least we can do [discussing attending commemoration ceremonies in Prince Edward Island] and I think I am more sensitive to it now that I've been overseas, and I've seen the delegation of individuals who have been there and have fought and lived through it and I feel that I owe it to them if nothing else. It's very powerful.", R.H. Thomson stated passionately: "It means respect. Respect for everyone

\footnotetext{
${ }^{1}$ Peter Mills, interview by Breanna Lester, November 20, 2020.

2 Sylvie Thibodeau-Sealy, interview by Breanna Lester, December 10, 2019.
} 
who went. It doesn't mean glorify. Respect to lives lost in the name of dot dot dot. You

have to fill out the rest of that sentence."” And, finally, Robert Löken posited:

It's interesting. What I came in with at VAC and what I thought is not my understanding or appreciation of it now. I came into this thinking that it is about the veterans ... and it still is ... the stories are about the veterans. The important part of all that is having an understanding that these veterans are not going to be here forever and when they're gone, it's not about the veterans anymore because they are gone; it's about making sure they are not forgotten. I came into this thinking I needed to do this for the veterans (which is still part of it), but really what I need to be doing it for is the youth to be able to get them to not forget that these veterans were here and a lot of it is about that now. ${ }^{4}$

Each of these sentiments vary, but there are common themes. Commemorations are respectful, necessary, (hopefully) impactful, and human. Commemorations can certainly "legitimize," they can evoke national identity, and they can be nationalistic in accordance with the definitions offered by scholars like Martin J. Murray, Jay Winter, and James E. Young, but that is not all they are. ${ }^{5}$ As this dissertation has shown, commemorations are also complicated, bureaucratic, emotional work.

In the introduction, I endeavoured to answer three central questions: How do commemorations work? Who or what are behind them? And, can we add nuance to what commemorations are beyond acts that maintain nationalism, national identity, and collective memory? An answer to the first question, given what I have explored in this dissertation, is that commemorations rely on three components: human participation; affective experience; and logistics. For the centenary, VAC planners made efforts to attract different kinds of audiences for the hundredth that might not have participated in

\footnotetext{
${ }^{3}$ R.H. Thomson, interview by Breanna Lester, September 16, 2019.

${ }^{4}$ Robert Löken, interview by Breanna Lester, November 20, 2019.

${ }^{5}$ Martin J. Murray, Commemorating and Forgetting: Challenges for the New South Africa (Minneapolis: University of Minnesota Press, 2013); James E. Young, The Texture of Memory: Holocaust Memorials and Meaning (New Haven: Yale University Press, 1993.
} 
the ninetieth. For example, Robert Löken and his team tried to locate more "ex-military" personnel as the veterans they usually count on to attend their ceremonies dwindle with every passing year. ${ }^{6}$ Also, as described in Chapter Three, one of VAC's mandates was to engage youth in the commemorations which changed the programming of the centenary events from a more militaristic approach to one focused more on artistic performances by artists younger audiences might have recognized such as Coeur de pirate, Paul Gross, and Johnny Reid. Innu teens Ethan Shiwak and Taylor Ivany also recited the "Commitment to Remembrance" in Inuktitut at Beaumont-Hamel 100. ${ }^{7}$ All of this took prior planning, it followed mandates and protocols, and, despite a barrage of criticism, the workers who planned and executed these events, the ones who missed birthdays and anniversaries because of their work, and who operated sometimes with little sleep, felt pride in their accomplishments.

Commemorations also rely on affect to succeed. In Chapter Two, we saw that the First World War landscape assemblages, Beaumont-Hamel, Vimy, and Passchendaele, each created immersive, affective environments that assist and challenge planners in delivering successful commemorative ceremonies. The sites that patrons visit have affective power just by virtue of their histories. Each one is part of a larger assemblage that includes monuments, trails, flora and fauna, and soil, that work together to create the inexplicable "on the ground" experience my interviewees discussed. Commemoration scholars continue to prioritize humans as sole participants in commemoration and do not give these affective landscapes the attention they deserve. Scholars understand that

\footnotetext{
${ }^{6}$ Robert Löken, interview by Breanna Lester, November 20, 2019.

${ }^{7}$ Cory Hurley, "Inuit teen proud to participate in Beaumont Hamel ceremony," Saltwire, Updated: September 30, 2017, https://www.saltwire.com/news/provincial/inuit-teen-proud-to-participate-inbeaumont-hamel-ceremony-113665/.
} 
commemorations are performative, but there is an entire nonhuman component to these performances that is largely missing from the literature. ${ }^{8}$

And, as Chapters Three and Four collectively showed, logistics are crucial to the success (or perceived failure) of commemorative events. In Caitlin Bailey's words: “you really need to have iron-clad logistics to be able to function with [commemorations] because otherwise your message does get completely lost." 9 People who work in the commemoration industry, public servants, battlefield tour operators, artists, and private sector employees, all have a vested interest in all three of these components converging to create unforgettable experiences that will facilitate the possibility of returning clientele. They want younger publics to stay engaged, they want to ensure affective experiences, and they work tirelessly to fulfil the logistical requirements of commemorative events because they know the consequences if they do not. As this dissertation has argued, a consideration of the granular logistical components of commemorative planning is missing from the existing scholarly understanding of what commemorations are. I do not disagree that commemorations are, as Jay Winter defined them, "publicly performed acts." 10 They are acts, yes, but they are also incredibly complicated and delicate practices.

The First World War centennial commemorations were not a singular event perpetuated by "the state" or "government." Rather, they emerged from an assemblage of people, bureaucracies, companies, ideas, landscapes, and material things (such as toilets).

\footnotetext{
${ }^{8}$ Murray, Commemorating and Forgetting, 15; Alex King, Memorials of the Great War in Britain: The Symbolism and Politics of Remembrance (London: Bloomsbury, 1998), 20; Jay Winter, Remembering War: The Great War between Memory and History in the 20 $0^{\text {th }}$ Century (London: Yale University Press, 2006), 20.

${ }^{9}$ Caitlin Bailey, interview by Breanna Lester, July 24, 2019.

${ }^{10}$ Winter, Remembering War, 31.
} 
Indeed, this dissertation has introduced fifteen individuals who worked on First World War commemorations, and their voices and perspectives were foregrounded throughout. However, as the Qualtrics survey and ATIP records demonstrated to me, there were many more individuals who were part of the commemorative assemblages described in this dissertation but who await other scholars' attention: most importantly, perhaps, are those who worked in education, on community-led projects, and museum workers. In other words, this dissertation adds a perspective of individuals to the study of commemoration, and further complicates the idea of "the public," "the nation," and "the government" as mass entities. And, as I argued in the conclusions of Chapters Two and Three, there are other variations of the assemblages because they are so prone to shift. This is one of the reasons why commemorations are difficult work to do and to study. Nonetheless, I believe the commemorative workers of this dissertation did the best they could with the tools they had; they documented their successes and failures in their post-mortems, and moved on to their next file, or in some cases, their next position. However, as a department, VAC learned many lessons from the centenary they captured during their post-mortem process. For example, an email from Lisa Arsenault, Strategic Advisor, Commemorations Division dated August 15, 2016 referenced an accompanying slide deck prepared for the Beaumont-Hamel After Action Discussion. In the slide deck, titled " $100^{\text {th }}$ Anniversary of the Battles of the Somme and Beaumont-Hamel - LESSONS LEARNED," best practices were divided into six categories: Delegation; Events; Operations; Logistics; Communications; and Domestic. In the first section on delegation, VAC agreed that "early engagement from VAC senior management and OMVA [Observatory for Military Veterans Affairs] on expectations around delegation 
composition [is] critical." ${ }^{11}$ This is perhaps in response to criticism around who were chosen as delegates at the ceremony. The other lesson learned for delegation regards maintaining "linkages between delegates and events [...] to [build] rich experiences, engaging Canadians and capturing media interest." ${ }^{\prime 2}$ Operational lessons were numerous, mostly in reference to the complexity of heightened security measures, the slow-moving registration process, site closures prior to events to allow time for set-up and take-down, and the provision of information to the public with respect to conditions outside the control of VAC innate in these kinds of events. ${ }^{13}$ Logistical lessons were concentrated mostly on in-event communication, earlier engagement with partners, and the presence of an "Event Management Service Provider" responsible for on-the-ground support to VAC and others at the events themselves. ${ }^{14}$ For communicative lessons, VAC suggested a continuation of the development of inclusive social media activity, and more bilingual engagement. ${ }^{15}$ Finally, in reference to their domestic efforts, VAC acknowledged the importance of early collaboration and coordination in-house and with partners to ensure a smooth execution of commemorative plans. ${ }^{16}$

Many of my VAC interviewees acknowledged that time management was, as Christina Gaudet put it, the "Achilles" of their department. ${ }^{17}$ The Commemoration Division needed more time to plan the event, including the choice in delegates and performers, and to improve external communications (presumably referring to

\footnotetext{
${ }^{11}$ ATIP, Veterans Affairs Canada, "100th Anniversary of the Battles of the Somme and Beaumont-Hamel LESSONS LEARNED," August 5, 2017.

${ }^{12}$ Ibid.

${ }^{13} \mathrm{Ibid}$.

${ }^{14}$ Ibid.

${ }^{15} \mathrm{Ibid}$.

${ }^{16}$ Ibid.

${ }^{17}$ Christina Gaudet, interview by Breanna Lester, January 22, 2020.
} 
international partners or stakeholders), promotion, and engagement. ${ }^{18}$ Another highlight of VAC's lessons learned briefing was discussion about bringing in "a historian or a veteran/scholar of Canada's military history [....] Delegates know Vimy was an important battle for Canada but are not always sure why." 19

Regarding their magnum opus, Vimy 100, VAC planners thought the digital online components were well-received by the public, though they wished they would have started disseminating the promotional material earlier. For example, Pamela Harrison communicated that 3579 media stories were shared, 41 million people interacted with Vimy 100-related material on Facebook, and 2.3 million people viewed the Vimy 100 website. ${ }^{20}$ This was perhaps VACs most-discussed achievement, and something it planned to continue for future commemorations. And, when I spoke with Sylvie Thibodeau-Sealy, it seemed VAC was already implementing some of its lessons learned for the future. She stated: "I know there is work being done now in terms of a ten-year plan of how we commemorate ten years from now and what that would look like."21

From outside government, VAC's stakeholders also suggested ways to improve for future commemorations. For Caitlin Bailey, consultation with historians is important if educational programming is incorporated into commemorative events. ${ }^{22}$ And, for Liberation Tours, better and earlier communication, and an understanding of the tourism industry are key to mitigating some of their central concerns I addressed in Chapter Four. ${ }^{23}$ Though the First World War centenary (and all VAC-led commemorative events)

\footnotetext{
${ }^{18}$ Ibid.

${ }^{19}$ Ibid.

${ }^{20}$ Ibid.

${ }^{21}$ Sylvie Thibodeau-Sealy, interview by Breanna Lester, Ottawa, December 10, 2019.

${ }^{22}$ Caitlin Bailey, interview by Breanna Lester, 24, 2019.

${ }^{23}$ John Cannon and Phil Craig, interview by Breanna Lester, August 13, 2019.
} 
are the responsibility of $\mathrm{VAC}$, there needs to be a greater emphasis placed on stakeholder outreach and collaboration to mitigate some of the larger criticisms interested external parties shared with me as part of their commemorative experience.

I initially expected this project to be a critique of how the Canadian federal government planned and managed the First World War centenary. Among other things, I was going to write about how proposals such as one that called for a "Mother Canada" monument, a massive maternal figure who would be put onto the shore of the Atlantic Ocean and feature hands outstretched towards Europe, were endemic of an ill-considered and ill-executed commemorative program for the First World War. ${ }^{24}$ However, as I listened to the work stories of my interviewees, and was given an opportunity to know and understand their professional and personal challenges, and came to appreciate the conditions under which they worked, this dissertation became something else entirely. As it happened, I was the ignorant one.

In the process of analysing the ATIP materials, interviews, and my ethnographic data, I was also encouraged to find a theory that allowed me to think differently about commemoration but, more importantly, to make sense of what the evidence showed. Assemblage theory afforded me the freedom to resist the need to find a single "story" of the First World War centenary that had a stable narrative arc as is more typical of histories of commemorative events. I was encouraged by the thinking of scholars like Kirk Savage and Sharon Macdonald who embraced the complexities intrinsic in their respective studies, fluid and open to change. Armed with Savage's imaginative conclusion comprised of his thoughts on what the Washington Mall could be, and

\footnotetext{
${ }^{24}$ Those unfamiliar with the "Mother Canada" concept, see: https://www.halifaxtoday.ca/localnews/advocates-still-not-giving-up-on-mother-canada-statue-for-cape-breton-2130505.
} 
Macdonald's use of "methodological pluralism," I took comfort in the uncomfortability of studying commemoration as process and practice. ${ }^{25}$ I listened to the sometimesconflicting experiences of my interviewees, knowing that it is impossible to provide a tidy "end" to this project. Even now, especially amidst a global pandemic, the commemorative process has shifted, but commemorative work continues (perhaps a topic of another study).

Like Jean-Pierre Morin, Steve Harris, and the group of military historians I mentioned in Chapter Four, there is still a part of me frustrated with how the past was manipulated to suit the needs of the present, why certain battles were privileged over others, and why historians in government are so constrained when it comes to advising those who have power not to continually perpetuate the Vimy as birth of the nation myth. Indeed, in my imagining of what future commemorations could encompass, they would not include an emphasis on the metanarratives I unpacked in Chapter Four. However, as I have learned through my investigation of the First World War commemoration through the lens of assemblage, commemoration is about so much more than metanarrative. Commemoration is a vocation, an industry, something that people anticipate and are proud of, and spend thousands of dollars to experience, but it is also expensive, stressful, and exhausting, especially when compounded by a mega-commemorative period such as the Road to 2017. So, despite my cynicism as an historian, I am excited by a potential future in which I can know what it is to work on commemorative files from the inside.

\footnotetext{
${ }^{25}$ Kirk Savage, Monument Wars: Washington, D.C., the National Mall, and the Transformation of the Memorial Landscape (Berkeley: University of California Press, 2005), 297-313; Sharon Macdonald, Memorylands: Heritage and Identity in Europe Today (New York: Routledge, 2013), 7.
} 
And there is a part of me, having studied the centenary, that did not want to feel any emotion as I finally got to experience the battlefield landscapes for myself. The truth is, as an Anglo-Canadian having grown up in a place where the felt poppy was sacred, where November 11 was a solemn occasion, I felt butterflies seeing the Vimy monument from a distance as my partner and I sped down the N17 towards Route des Canadiens in our Peugeot 108, a feeling that only grew stronger as I approached the monument on foot and looked up in awe of its majesty (Figure 6.1). Whether I expected it or not, I was at the very least a secular pilgrim. I did not weep at Beaumont-Hamel like Douglas Ballam, but I did not "collect" the Canadian monuments as Pokémon cards like David Patterson suggested either. I experienced the "on the ground" feeling. I felt pride, respect, and even awe at different points throughout my journey. But this pseudo-religious experience was also nested with my enjoyment of a wood-fired pizza and pint at a local restaurant (with free and clean bathrooms, I might add), and a much-needed jacuzzi at my Airbnb in the evenings. The commemorative sites I visited are special, necessary, and part of larger assemblages that include bathrooms and Jacuzzis. Even though I am a person who chooses not to wear a poppy on or before Remembrance Day, puts up Christmas decorations before November 11, and rolls her eyes at the performative patriotism on display at sporting events, it was a powerful, affecting experience to walk the battlefields, touch the white limestone of the majestic Vimy memorial, to count my steps to Danger Tree, and to listen to the stories of the people who, despite all their hardships, continue to advocate for the importance of these places. Lest I forget. 


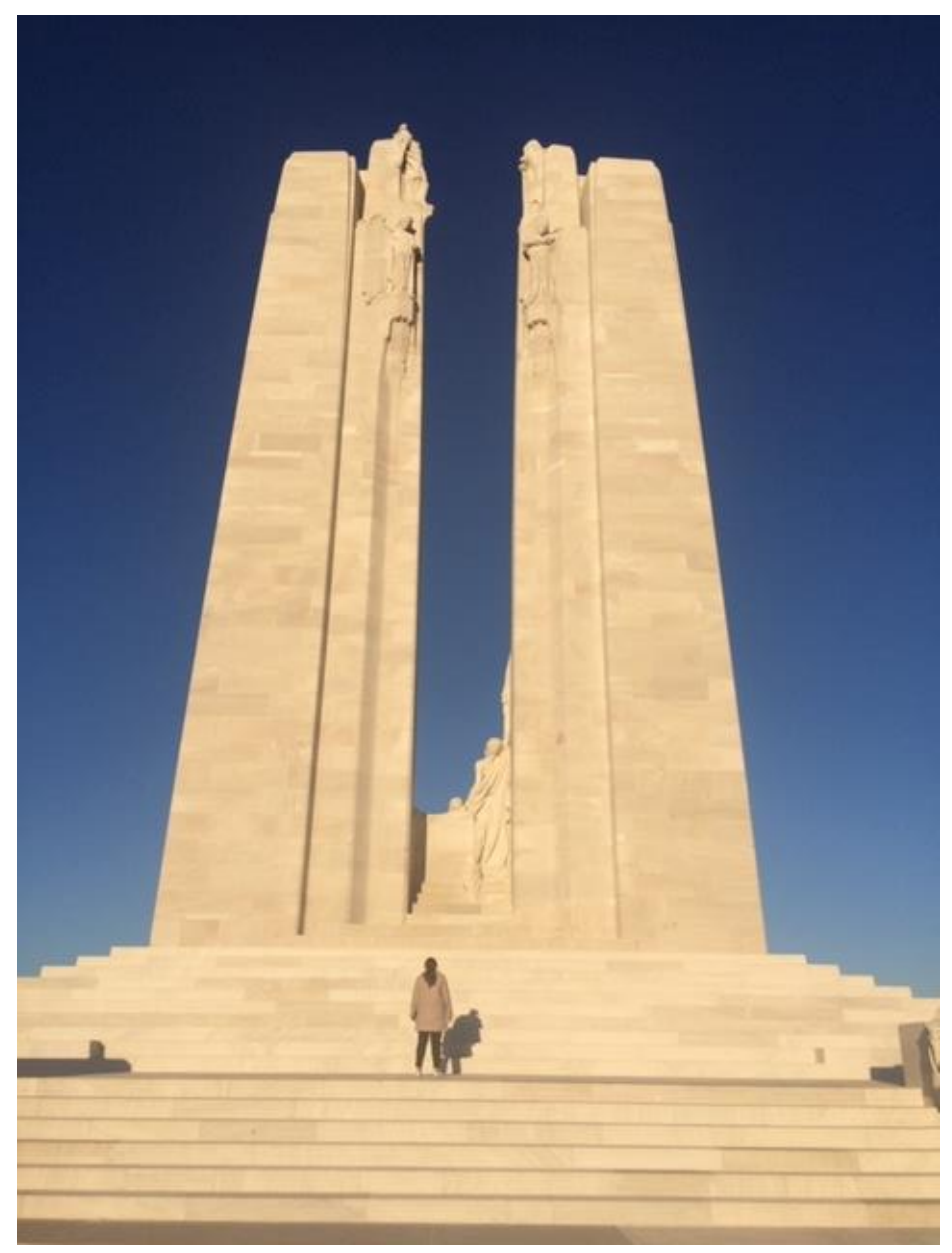

Figure 6.1 - My first visit to the Vimy memorial, taking in the grandeur. Photograph taken by Breanna Lester, October 2019. 


\section{Appendix A: Biographies of Centenary Workers}

\section{Tim Cook}

Many know Tim Cook as an icon in the field of Canadian military history. During his lengthy career, he has produced a canon of monographs relating to Canada's twentieth century conflicts. I was initially interested in interviewing Cook, not because of his status or his accolades, but rather because I was struck by the concluding chapter of his centenary book, Vimy: The Battle and the Legend, in which he writes about his experience looking up at the Vimy monument in awe, experiencing emotion, but unable to pinpoint why. I was also curious to know what it was like to act as a CBC correspondent and co-anchor at the Vimy 100 and Armistice anniversaries. Cook was born in Kingston, Ontario and moved to Ottawa when he was very young. Both of his parents have PhDs in Canadian History and so he grew an affinity for it from a young age. He attributes his love of war history to two major events: the first, he said, was when his parents took him to the Western Front when he was seventeen years old and when he went off to do an undergraduate degree at Trent University. He also holds a master's degree from the Royal Military College of Canada and a PhD from the University of New South Wales in Australia. Cook's career began straight after his master's when he obtained an Archivist position at what was then called the National Archives of Canada (now Library and Archives Canada) and subsequently landed a position as an historian at the Canadian War Museum where he has worked ever since. $^{1}$

\footnotetext{
${ }^{1}$ Tim Cook, interview by Breanna Lester, May 30, 2019.
} 


\section{Douglas Ballam}

I received Douglas Ballam's name from Tim Cook who has recently met him at a conference he attended in Newfoundland. Ballam is a thirty-three-year service reservist in the Royal Newfoundland Regiment. His day job (as he described it) was to coordinate Memorial University's First World War commemorative program. He is a third-generation Newfoundlander; his grandfather arrived in Newfoundland 1864 and died in 1961. Ballam described himself to me as a "firstgeneration Canadian."2 In our interview, he often referred to the visiting of battlefields as "pilgrimage" and I could hear how passionate he was about his experiences being involved in pilgrimages to the Western Front for over thirty years. Ballam's perspective as a native Newfoundlander was much needed and adds a crucial and often contradictory perspective that complicates how the centenary commemorations are and should be studied considering Newfoundland's unique history and position as it relates to Beaumont-Hamel and July 1 as a day of both mourning and celebration.

\section{Caitlin Bailey}

As the first woman I interviewed, and the only woman I interviewed working adjacent to the federal government, Bailey's perspective was refreshing and incredibly important. Originally from Calgary, Alberta, she currently works as the Executive Director for a non-profit company called the Vimy Foundation, with offices in both Montreal, Quebec and Toronto, Ontario. Bailey was perhaps the

\footnotetext{
${ }^{2}$ Douglas Ballam, interview by Breanna Lester, July 27, 2019.
} 
most forthcoming of all my interviewees with her childhood commemorative experiences. Though she told me that her career happened by accident, her passion for the First World War began in childhood. She remembers discovering that her regular watching of Sesame Street was "pre-empted by [an] extremely solemn ceremony" on November $11 .{ }^{3}$ She also describes being interested in "the visuals around the First World War (the photographs) and reading books as [she] got a little bit older that were stories about the First World War [....] As a child [she] had a very strong sense of the emotion around commemorations," and "always [felt] very emotionally affected by it." ${ }^{4}$ Despite this, Bailey pursued a degree in Russian literature and a graduate degree in Library Science and Cultural Management and subsequently obtained a position at the Canadian Centre for the Great War, and later her position as Executive Director at the Vimy Foundation. Though not Québécois, she was able to provide some much-needed insight into the passionate feeling of francophone culture as it relates to the First World War. The emotional connection to commemorative events is important to her, and we discussed this at length during our conversation; especially how important ironclad logistics and consultation are in the process of instilling emotion at commemorative events. Ultimately, Bailey champions educating the public on the human cost of war as one of her central missions, and she sounded deeply passionate in her endeavours. ${ }^{5}$

${ }^{3}$ Caitlin Bailey, interview by Breanna Lester, July 24, 2019.

${ }^{4}$ Ibid..

${ }^{5}$ Ibid. 


\section{Robert H. (R.H.) Thomson}

I first encountered R.H. Thomson's project The World Remembers in the conclusion to Ian McKay and Jamie Swift's centenary book, The Vimy Trap: Or How We Learned to Stop Worrying and Love the Great War. Described as a "post-patriotic commemoration," McKay and Swift position Thomson on the forefront of a new way of thinking about commemoration as less of a nationalistic endeavour, and more of an international recognition. ${ }^{6}$ Thomson is an actor and an artist and therefore has a unique perspective on commemorations beyond the ways described by McKay and Swift in The Vimy Trap. Thomson first encountered the First World War as a child reading 700 family letters collected by his great aunt. As he shared, his father's "five uncles went over; two were killed there, two died afterwards in the sanatorium in Gravenhurst in the 1920s, so [his] great grandmother lost four out of five sons to that war." as neither a "history person nor a military person," Thomson decided to turn them into a play: The Lost Boys. As he performed this in Ottawa, Winnipeg, and Toronto, patrons would approach him and tell their own family war stories and eventually "made [him] realize the universality of the stories that sit out there in all of us." " From this stage experience, The World Remembers was born. During our interview in a small Toronto coffee shop, we talked about the difficulties in navigating relationships with governments around the world as he attempted to

\footnotetext{
${ }^{6}$ McKay and Swift, The Vimy Trap: Or How We Learned to Stop Worrying and Love the Great War, p.268-269.

${ }^{7}$ R.H. Thomson, interview by Breanna Lester, September 16, 2019.

${ }^{8}$ Ibid.
} 
gain their support and resources for The World Remembers, and Canada's unique

position as a diverse nation to be able to accomplish a project of this kind.

Thomson remains hopeful to grow his vision and truly make The World

Remembers a global commemoration of the First World War. As he stated in a

2018 Maclean's interview,

It goes back to Lost Boys and how my maternal family suffered terrible losses in the First World War. But it was the stories that walked in the door of my dressing room every night I performed it that really made me think. Visitors and friends all started telling me their families' stories of war. Not "big" stories, but the power of history is in the personal, so therefore, logically, every person's story must be told. And that is The World Remembers, as impossible as the idea is: how do you tell—or at least note - every soldier's story? Someone has to do it. How can you go through the centenary years of that incredible conflict and not name the dead? What I'm stunned at is that no one else has. That's what leaves me gasping on the floor. ${ }^{9}$

\section{Jean-Pierre Morin}

I first met Crown-Indigenous Relations and Northern Affairs Canada (CIRNAC formerly INAC) historian, Jean-Pierre Morin when he was a visiting scholar at Carleton University and his involvement in this dissertation runs deeper than there is space to mention here. Though a settler-colonial scholar himself, Morin added an Indigenous-centred perspective I did not achieve in my other interviews.

Having worked at CIRNAC for decades, Morin is an archive of knowledge on Indigenous participation in Canada's national commemorative efforts. As he (from Cornwall, Ontario) communicated in our interview, his "entire life was about commemorative activities;" his father was the manager of historians and

\footnotetext{
${ }^{9}$ Brian Bethune, "RH Thomson's The World Remembers commemorates sacrifice, one name at a time," Maclean's, November 7, 2018, https://www.macleans.ca/history/rh-thomsons-the-world-remembers-mixesart-with-remembrance/.
} 
archaeologists at Parks Canada and so Morin spent a significant amount of time as a child commemorating Canadian conflicts. ${ }^{10}$ The crux of our conversation was around what CIRNAC (and the Government of Canada on the whole) envisioned for the First World War centenary, specifically its connection to the War of 1812 bicentennial and Canada 150.

\section{Steve Harris}

Steve Harris is an historian at the Directorate of History and Heritage. Like my other interviewees, Harris has a wealth of knowledge regarding national commemorative efforts dating back to the mid-1990s. As he states in our interview, his first big commemoration was Hong Kong 2002, then Dieppe 2002. Harris maintains that his role at DHH is to "prevent bad history," but remains cognisant of the fact that neither himself nor his department can control the government's overall message. However, he was able to share some of his personal thoughts on how he believed the centenary went and how it can be altered in the future. Harris expressed disappointment in the dichotomy between education and commemoration, clarifying that the national commemorations are too narrow, but there is no room within the current commemorative structure to allow for a breadth of educational material to exist because of the continued focus on the 'Big Three': Beaumont-Hamel, Vimy, and Passchendaele.

\section{Ocel Dauphinais-Matheson}

I met Ocel Dauphinais-Matheson while he was working on a temporary Parks Canada contract as Visitor Experience Manager at Vimy Ridge. Originally from

\footnotetext{
${ }^{10}$ Jean-Pierre Morin, interview by Breanna Lester, July 5, 2019.
} 
Prince Edward Island, Dauphinais-Matheson had recently moved to France with his partner less than a year before I met him in the lobby of the recently constructed Vimy Ridge Visitor's Centre. As we were on a limited schedule and travelling to Ypres, Belgium for the sunset ceremony at Menin Gate, I was not able to ask him about his upbringing or how he ended up in his chosen vocation. However, his enthusiasm for the site, his guides, and the history of the ground on which we stood was difficult to miss. Dauphinais-Matheson has immense gratitude and appreciation for the work he does and the experiences he has had in his role.

\section{Robert Löken}

Originally from La Tuque, Quebec, Robert Löken has lived in almost every Canadian province because of his work in the hotel industry. As a child, Löken was a cadet and therefore attended many commemorative ceremonies. Though, as he says, he never really appreciated them until he assumed his current role in the federal government. He also comes from a family of farmers, and though he is not related to any veterans himself, he did reveal that his family assisted in food production from home during the First World War. ${ }^{11}$ Following his work in the hotel industry, Löken worked for ten years as the Manager for Visitor's Service, Safety, and Infrastructure. When we spoke, he was nearly three years into his job as the National Manager for Honours, Awards, and Commemorations at Veterans Affairs Canada in Ottawa, Ontario. Though Löken assumed his position just after the Vimy commemoration file was ending, Löken worked on all major

\footnotetext{
${ }^{11}$ Robert Löken, interview by Breanna Lester, November 20, 2019.
} 
commemorative events following it, the biggest ones being Canada's Hundred Days, D-Day, and the Italian Campaign. Löken and I talked at length about the nuances of commemorative events planning over general event planning (the field he had gained expertise in during his tenure in the hotel industry). As he explained, "an event is an event is an event."12 The other large theme of our conversation was the issue of veterans; Löken felt very strongly and emotionally about the passing of time, and with it, the passing of veterans; his team receives hundreds of messages a year from relatives of recently deceased veterans and the weight those messages showed.

\section{Peter Mills}

Peter Mills grew up in New Brunswick, his great uncle served in the Second World War, and Mills himself served briefly in the Canadian Armed Forces as a reservist in the Royal Canadian Navy. When we met in November 2019, Mills was the Director of Honours, Decorations, and medals with the Office of the Secretary to the Governor General in Ottawa, Ontario. Prior to obtaining that position, he was the manager for all domestic commemorations and worked extensively on the commemorations of Canada's Last Hundredth Days. However, for the majority of the centenary, he was a special advisor to the Director General of VAC responsible for a special overseas task force dedicated to what he calls "the big centennials of the First World War," including Vimy, Passchendaele, and Beaumont-Hamel. ${ }^{13}$ During our meeting, Mills and I discussed VAC's constraints in planning and executing large-scale commemorative events, and he was

${ }^{12} \mathrm{Ibid}$.

${ }^{13}$ Peter Mills, interview by Breanna Lester, November 20, 2019. 
particularly hard-hit by the criticisms surrounding the Beaumont-Hamel

commemoration because, as he put it, "[he] owned it, because it was [his]."14

Though perhaps more sensitive to historical intricacies than most, due to his degrees in history and education, Mills made it clear that though commemorations (and especially war commemorations) are important and should be observed, the skills required to execute these events is not dissimilar to any other event. ${ }^{15}$

\section{Sylvie Thibodeau-Sealy}

Sylvie Thibodeau-Sealy grew up in Bathurst, New Brunswick. She went to a francophone high school, and when she graduated, she obtained her degree in sociology and political science from Acadia University in Nova Scotia, and subsequently obtained a Bachelor of Social Work degree from Dalhousie University. Her grandfather was in the Second World War and spoke to her informally about his experience when she was a child. Though like many public servants, Thibodeau-Sealy frequently changes job titles, she was recruited by the commemorations division of VAC because she had been on a negotiation team with VAC and in negotiations with the Province of Quebec regarding the transfer of a hospital for six years. In 2016, she became a Strategic Advisor to a Director General in policy and research and subsequently applied to be a Director and was successful. In January of 2017, Thibodeau-Sealy became a Director General of Overseas Commemorations. She was candid in our interview and shared a perspective on the centennial I had not previously heard, nor could have imagined. We talked at length about the hardships of commemoration planning and the

${ }^{14} \mathrm{Ibid}$.

${ }^{15}$ Ibid. 
emotional toll it takes on staff, especially those who were taken on strength without previous experience working in extraordinarily stressful environments. It was clear to me that though Sylvie was extremely passionate about the work she had accomplished, she was also emotionally drained by the end, commenting that “it was probably the hardest thing I've ever done in my entire career and I don't think anything will ever compare."16

\section{Christina Gaudet}

Christina Gaudet grew up just outside of Charlottetown, Prince Edward Island and later studied Transportation and Tourism at Sir Sanford Fleming College in Peterborough, Ontario. Once she graduated, she worked in the hospitality industry for a while before moving abroad to Scotland to work at a resort there. While she was there, a member of her family suffered an illness and while at home, she reconnected with the man who would later become her husband and decided to stay and apply for a job at VAC. In 1998, she was hired by the commemoration division and has been there ever since. When I spoke with her in early 2020, Gaudet was in the process of transitioning out of her role as Program Manager to a position as Projects Coordinator at VAC. As the longest-serving VAC employee I talked to, we spent a lot of our phone conversation discussing the ways in which commemorative processes have changed over time, including technological advances, security, and partnerships with other departments and private companies. ${ }^{17}$ However, having just recently talked with Sylvie Thibodeau-Sealy,

\footnotetext{
${ }^{16}$ Sylvie Thibodeau-Sealy, interview by Breanna Lester, December 10, 2019.

${ }^{17}$ Christina Gaudet, interview by Breanna Lester, January 22, 2020.
} 
it was the discussions around stress and the emotional affects of her demanding position not only on her, but on her family as well that struck me.

\section{John Cannon and Phil Craig}

Phil Craig started a museum in the small town of Keswick, Ontario in the 1990s and his long-time friend John Cannon joined him five years after its doors opened. In 2006, Cannon and Craig obtained a grant to take a couple of their museum volunteers to the battlefields of France where they both decided that they should be running battlefield tours in addition to their efforts at the museum. Craig's background as a professional actor and storyteller and interest in the First World War together with Cannon's organizational and marketing abilities made them an ideal team for this kind of work. Over the phone, I sensed that Cannon and Craig felt passionately for their work and have worked tirelessly to maintain real connections with their clients and the places they take them; they ensure their patrons not only explore the battlefields and learn about the twentieth century battles, but also get a taste of local cuisine. Cannon and Craig's perspective on the centenary was a necessary one; they and the rest of the battlefield tour operators I spoke with act as an opposing perspective to that of the VAC employees behind the events, and though Cannon and Craig became much more animated when we discussed the centenary, damning VAC's efforts as a "fucking shit show," it comes from a place of passion for their work. ${ }^{18}$

\footnotetext{
${ }^{18}$ John Cannon and Phil Craig, interview by Breanna Lester, August 13, 2019.
} 


\section{Jérémie LeBlanc}

Jérémie LeBlanc was my first point-of-contact at the Canadian Battlefields Foundation. A librarian at St. Paul University in Ottawa, Ontario, LeBlanc first learned about the Foundation having been a student recipient of the bursary. We talked about the history of the Foundation, the structure of the tours and student participation, and the commemoration fatigue that goes along with doing repetitive tours through the centenary years. Though the Canadian Battlefields Foundation almost exclusively runs their tours for post-secondary school students and recent graduates (which are outside the parameters of this dissertation), LeBlanc's insight into the battlefield tour industry, his experience leading and participating in tours, and putting me in contact with my final interviewee were invaluable to this project. ${ }^{19}$

\section{David Patterson}

Like Jérémie LeBlanc, David Patterson first learned about the Canadian Battlefields Foundation as a student on one of their tours. This tour occurred in 1997 when he was a doctoral student at Concordia University. Three years later, he would find himself on the Board of Directors of the Foundation, and since then, Patterson has led 16 student tours. In addition, he assisted some of his colleagues leading commercial tours in the late 1990s and early 2000s and, from there, decided to go it alone and start his own tour company called Fields of Fire Tours. Until the centenary, Patterson kept his tours small, but when demand grew during the centenary years, he grew to include coach tours. We discussed what

\footnotetext{
${ }^{19}$ Jérémie LeBlanc, interview by Breanna Lester, August 27, 2019.
} 
happens when their hired vans get stuck in the mud trying to get in and out of little-known battlefield sites, hunting for World War One shrapnel shells along the road, and the importance of always knowing where the closest McDonald's is for the clean bathrooms. ${ }^{20}$

${ }^{20}$ David Patterson, interview by Breanna Lester, September 3, 2019. 


\title{
Appendix B: Certification of Institutional Ethics Clearance
}

\author{
Garleton \\ Office of Research Ethics \\ 503 Robertson Hall | 1125 Colonel By Drive \\ Ottawa, Ontario K1S $5 \mathrm{~B} 6$ \\ 613-520-2600 Ext: 2517 \\ ethics@carleton.ca
}

\section{CERTIFICATION OF INSTITUTIONAL ETHICS CLEARANCE}

The Carleton University Research Ethics Board-A (CUREB-A) at Carleton University has renewed ethics approval for the research project detailed below. CUREB-A is constituted and operates in compliance with the Tri-Council Policy Statement: Ethical Conduct for Research Involving Humans (TCPS2).

Title: The Canadian Centenary Project

Protocol \#: 108872

Project Team Members: Brianna Lester (Primary Investigator)

John C. Walsh (Research Supervisor)

Department and Institution: Faculty of Arts and Social Sciences\History (Department of),

Funding Source (If applicable):

Effective: April 25, 2019

Expires: April 30, 2020

Please ensure the study clearance number is prominently placed in all recruitment and consent materials: CUREB-A Clearance \# 108872.

\section{Restrictions:}

This certification is subject to the following conditions:

1. Clearance is granted only for the research and purposes described in the application.

2. Any modification to the approved research must be submitted to CURLB-A. All changes must be approved prior to the continuance of the research. 
3. An Annual $\Lambda$ pplication for the renewal of ethics clearance must be submitted and cleared by the above date. Failure to submit the Annual Status Report will result in the closure of the file. If funding is associated, funds will be frozen.

4. A closure request must be sent to CUREB-A when the research is complete or terminated.

5. During the course of the study, if you encounter an adverse event, material incidental finding, protocol 5. During the course of the study, if you encount of Unanticipated Problems Form, found here: https:/carleton.ca/researchethics/forms-and-templates/

6. It is the responsibility of the student to notify their supervisor of any adverse events, changes to their application, or requests to renew/close the protocol.

7. Failure to conduct the research in accordance with the principles of the Tri-Council Policy Statement: Ethical Conduct for Research Involving Humans 2 nd edition and the Carleton University Policies and Procedures for the Ethical Conduct of

Research may result in the suspension or termination of the research project.

Upon reasonable request, it is the policy of CUREB, for cleared protocols, to release the name of the PI, the title of the project, and the date of clearance and any renewal(s)

Plcase email the Research Compliance Coordinators at cthics@carleton.ca if you have any questions.

\section{CLEARED BY:}

Date: April 25, 2019

Bernadette Campbell, PhD, Chair, CUREB-A

Natasha Artemeva, PhD, Vice Chair, CUREB-A 


\section{Appendix C: Ethics Consent Form}

Title: Lest We Commemorate: Canada's First World War Centenary

Date of ethics clearance: To be determined by the REB (as indicated on the clearance form)

Ethics Clearance for the Collection of Data Expires: To be determined by the REB (as indicated on the clearance form)

I choose to participate in a study on the Canadian First World War centenary commemorative experience. This study aims to understand how Canadians interact with commemorative spaces. The researcher for this study is Breanna Lester in the Carleton University Department of History.

She is working under the supervision of John C. Walsh in the Carleton University Department of History.

This study involves one [60 minute] interview. With your consent, interviews will be audio-recorded. Once the recording has been transcribed, the audio-recording will be destroyed.

The questions to be asked of you during this interview poses minimal risk. However, all responses will be kept anonymous unless you indicate otherwise. Furthermore, you may request that certain responses not be included in the final project. Should you experience any distress, you may terminate the interview at any time.

You have the right to end your participation in the study at any time, for any reason. You can withdraw by phoning or emailing the researcher or the research supervisor. If you withdraw from the study, all information you have provided will be immediately destroyed.

All research data, including audio-recordings and any notes will be encrypted. Any hard copies of data (including any handwritten notes or USB keys) will be kept in a locked cabinet at Carleton University. Research data will only be accessible by the researcher and the research supervisor. 
Once the project is completed, all research data will be kept for five years and potentially used for other research projects on this same topic. At the end of five years, all research data will be securely destroyed. (Electronic data will be erased and hard copies will be shredded.)

If you would like a copy of the finished research project, you are invited to contact the researcher to request an electronic copy which will be provided to you.

The ethics protocol for this project was reviewed by the Carleton University Research Ethics Board, which provided clearance to carry out the research. If you have any ethical concerns with the study, please contact Dr. Andy Adler, Chair, Carleton University Research Ethics Board-A (by phone at 613-520-2600 ext. 2517 or via email at).

\section{Researcher contact information:}

Breanna Lester

Department of History

Carleton University

Tel: 613 520-2828

Email: breannalester@cmail.carleton.ca

\section{Supervisor contact information:}

John C. Walsh

Department of History

Carleton University

Tel: 613 520-2600 ext 2821

Email: john.walsh@carleton.ca

Do you agree to be audio-recorded: Yes No 


\section{Appendix D: Interview Guide}

\section{$\underline{\text { Section One: General Background }}$}

Name of Interviewee and place of interview

Where did you grow up?

Education - where did you go to school? Post-secondary?

Can you recall any commemorative experiences you had as a kid?

$\underline{\text { Section Two: Occupation }}$

What is your current job title?

How long have you held your current position?

Could you briefly describe what your job entails more generally?

As it is related specifically to the centenary commemorations of the First World War, could you describe what aspects of the commemorations you worked on? When did you start the planning phase?

Did your department consult with other departments or divisions, or with the public?

Could you describe any personal challenges you faced as you progressed through your role as ?

Could you describe some highlights of our job that stick out to you? Any personal fulfilment you felt while working on this project?

I've gone through several pages of planning and policy documents on the government's approach to the commemorations, and I was struck by just how much work goes into realising these events. I'm really interested in the on-the-ground labour elements of commemorations. What can you tell me about the practical elements of realising a largescale commemorations?

I've been reading a lot about the funding of these large-scale commemorations as well. Do you think the funding aspect impacted what transpired?

Did the change in government in 2015 impact how the commemorations occurred?

Reflecting on the centenary now that it has ended, could you comment on lessons learned and aspects you would change for future commemorations?

Section Three: Commemorative Experience

Do you have a personal connection to the First World War?

Have you ever visited a First World War battle site? Where did you go? What was your experience like?

Did those experiences assist you in your current role? 


\section{$\underline{\text { Additional Questions for Battlefield Tour Guides and Operators }}$}

Could you describe how your tours are structured? Perhaps your most popular tour if you operate several.

Is there a particular reason you decided to structure your tour in this way? Perhaps logistically?

Could you describe your typical clientele? 


\section{Appendix E: Qualtrics Survey Questions}

Part 1 (multiple choice)

Q1 - What is your gender?

Male

Female

I prefer not to answer

Q2 - What is your age?

$18-30$

$30-50$

$50+$

Q3 - What is your highest level of education?

High School

Post-Secondary Degree or Diploma (Bachelors, College Diploma)

Advanced Post-Secondary Degree (Master's, PhD)

Q4 - Are you currently enrolled in or affiliated with a post-secondary institution?

Yes

No

Q5 - How would you rate your interest in Canadian history?

Strong interest

Mild interest

Indifferent

Strong dislike of Canadian history

Q6 - Would you say that learning Canadian history makes you proud to be Canadian? 
Yes

No

Prefer not to answer

Q7 - Are you a veteran or a member of the Canadian Armed Forces?

Yes

No

Q8 - Are you related to a war veteran? Please feel free to interpret "related" as you see fit.

Yes

No

\section{Part 2 (short answer)}

Have you contributed to, worked for, or participated in the 2014-2018 First World War commemorations? If so, in what capacity?

Have you ever participated in a pilgrimage and/or First World War Battlefield Tour? If so, what calendar year(s) did you do so?

Regardless of how you have answered any of these questions, would you be interested in being interviewed for this project?

If you chose "Yes" in Q11, please leave an email address and/or phone number below to indicate how you would prefer to be contacted. 


\section{Appendix F: Table Showing Access to Information and Privacy (ATIP) Tracking Chart}

\begin{tabular}{|c|c|c|}
\hline Organization Name & Date ATIP requested & $\begin{array}{l}\text { Date ATIP request } \\
\text { returned }\end{array}$ \\
\hline $\begin{array}{l}\text { Veterans Affairs Canada } \\
\text { (VAC) }\end{array}$ & $\begin{array}{l}\text { January 4, } 2017 \text { (amended } \\
\text { and re-submitted on } \\
\text { October 29, 2017). }\end{array}$ & $\begin{array}{l}\text { Returns dated: } \\
\text { February 15, 2018; } \\
\text { March 19, 2018; } \\
\text { May 14, 2018; } \\
\text { June 12, 2018; } \\
\text { June 29, } 2018 \text { (2 CDs); } \\
\text { July 3, 2018 (2 CDs); } \\
\text { July 10, 2018; } \\
\text { July 12, } 2018 \text {. }\end{array}$ \\
\hline $\begin{array}{l}\text { Department of National } \\
\text { Defence (DND) }\end{array}$ & January 4, 2017. & $\begin{array}{l}\text { Received email from the } \\
\text { "Backlog Team" on } \\
\text { January } 27,2020 \text { asking if } \\
\text { I was still interested in } \\
\text { receiving material to which } \\
\text { I respectfully declined. }\end{array}$ \\
\hline Canadian Heritage $(\mathrm{PCH})$ & December 26, 2016. & $\begin{array}{l}\text { Partial return on March } 5 \text {, } \\
2018 . \\
\text { Email received asking if I } \\
\text { was still interested in } \\
\text { obtaining documents } \\
\text { supporting my request in } \\
\text { December } 2018 \text {. Received } \\
\text { no response. }\end{array}$ \\
\hline $\begin{array}{l}\text { Indigenous and Northern } \\
\text { Affairs Canada (INAC) }\end{array}$ & September 9, 2017. & $\begin{array}{l}\text { Returns dated: } \\
\text { January 9, 2018; } \\
\text { March 13, 2018. }\end{array}$ \\
\hline
\end{tabular}




\section{Appendix G: \\ How to Navigate the Access to Information and Privacy (ATIP) Process}

\section{1) Start Early}

- In many cases, the ATIP process is slow. The earlier you can submit your request, the sooner you will receive a response. Delivery times vary from department to department.

\section{2) Seek Advice from an Expert}

- When I started out, I was not aware that researchers could submit ATIP requests and as a result, I was completely lost when it came to submit my requests. However, along the way, I asked questions, learned which departments to submit to, and how to submit a request that would yield the results I desired. Building rapport with the ATIP officer who contacts you to discuss wording is also important. This proved invaluable for me.

\section{3) Learn 'ATIP-ese'}

- Getting the language of the ATIP request was difficult and as mentioned, I only realized this after fielding questions from ATIP Officers and receiving advice from experts. Below are examples of requests I sent:

To Department of National Defence (DND) in January 2017: All records (final or most recent version) produced between January $1^{\text {st }}, 2014$ to present (Jan. $4^{\text {th }}$, 2017) that pertain to the commemoration of the First World War.

To Veterans Affairs (VAC) as a resubmission in October 2017 after expert advice:

1) Requesting all records (final or most recent versions) produced between January 1, 2010 to present (including emails, correspondence, decisions, briefing notes, memos, and notes) that pertain to the commemoration of the 100th anniversary of the First World War and Vimy Ridge, including information regarding funding and events.

2) Requesting all records regarding the comparison of Canada's role in First World War commemoration with that of other countries.

The second example is much more detailed and specific and, in the end, resulted in a relatively swift and fruitful return.

\section{4) Be Persistent}

- Though responding to ATIP requests is the responsibility of those working in the government ATIP departments, it is common that single requests are missed entirely. It is also possible (such as in my case) that the ATIP officer you were corresponding with changes jobs a year after you submitted your request, resulting in the loss of your personal connection to your request. Therefore, it is imperative that you remain persistent. 


\section{5) Understand the Limitations of the Method}

- Using ATIP is not a perfect method and in fact it is not a reliable source on its own. In addition to the length of time required to obtain the information, the finicky nature of the process, and the language involved in seeking the information you require, I found approximately $1 / 3$ of the $8000+$ pages I received was redacted. This meant that for me to understand the full picture, I needed to fill the gaps with other methodologies. 


\section{Bibliography}

\section{Government Documents}

$37^{\text {th }}$ Parliament, $1^{\text {st }}$ Session: Sub-Committee on Veterans Affairs of the Standing Committee on National Defence and Veterans Affairs. March 21, 2002. https://www.ourcommons.ca/DocumentViewer/en/37-1/SVET/meeting-6/evidence (accessed January 2, 2021).

Government of Canada. "Vimy Ridge Day Act." Statutes of Canada 2003, c.6. (accessed June 30, 2020).

Order in Council of Canada, 1965, Commemoration Order of 1965, P.C. 1965-788. https://www.veterans.gc.ca/pdf/about-us/reports/9650413p.pdf

Veterans Affairs Canada. "Repair, Restoration and Rehabilitation of Canada's First World War Memorials in Europe - Audit Report." February 2004.

\section{Access to Information and Privacy Documents}

Canadian Heritage. Access to Information and Privacy Request \# A-2015-00141. File AI-2017-00277 / MH. CD-ROM. Gatineau, Quebec.

Indigenous and Northern Affairs Canada. File A-2017-00890 / EF. Ottawa, Ontario.

Veterans Affairs Canada. File AI-2017-00024 / JAG. 1347 pages. CD-ROM.

Charlottetown, Prince Edward Island.

-- File AI-2017-00025 / SDK. 733 pages. CD-ROM. Charlottetown, Prince Edward Island.

-- File AI-2017-00026 / AMP. 1234 pages. CD-ROM. Charlottetown, Prince Edward Island.

-- File AI-2017-00028 / TCC. 34 pages. CD-ROM. Charlottetown, Prince Edward Island.

-- File AI-2017-00027 / TCC. 381 pages. CD-ROM. Charlottetown, Prince Edward Island.

-- File AI-2017-00029 / MAB. 1040 pages. CD-ROM. Charlottetown, Prince Edward Island.

-- File AI-2017-00030 / MAB. 1765 pages. CD-ROM. Charlottetown, Prince Edward Island.

-- File AI-2017-00032 / JAG. 873 pages. CD-ROM. Charlottetown, Prince Edward Island.

\section{Film / Television}

The Agenda with Steve Paikin. "A Century After Vimy.” TVO. April 12, 2017. 
A Nation Soars, "A Nation Soars - Commemorating Canada's Great War Flyers,": http://www.anationsoars.ca/ (accessed on July 2, 2020).

Canadian Broadcasting Corporation. "Trail of the Caribou" Directed by Allan Hawco and Mark Critch. July 1, 2016.

CTV News. "Vimy Ridge: 'What free people are capable of when the essential is at stake'." The Canadian Press. April 9, 2017.

Jeremy Diamond, interview by Marc Montgomery, Veteran's Week in Canada: Vimy Ridge Education Centre, Radio Canada International 4 November 2013.

YouTube: Hockey Night in Canada - Coach's Corner - April 7 $7^{\text {th }}, 2012$. https://www.youtube.com/watch?v=21Y8UvP-UhA.

YouTube: Hockey Night in Canada - Coach's Corner - April 5, 2014. https://www.youtube.com/watch?v=xWzFn291qBo\&ab_channel=p00njabiHD.

\section{Interviews}

Interview with Caitlin Bailey, Executive Director, The Vimy Foundation, July 24, 2019.

Interview with Christina Gaudet, Manager, Overseas Events and Ceremonies, Commemoration Division, Veterans Affairs Canada, January 22, 2020.

Interview with David Patterson, Director, Fields of Fire Battlefield Tours, September 3, 2019.

Interview with Douglas Ballam, Events Coordinator, Marketing \& Communications, Memorial University, July 17, 2019.

Interview with Jean-Pierre Morin, Historian, Indigenous and Northern Affairs Canada, July $5,2019$.

Interview with Jérémie LeBlanc, Chief Librarian, St. Paul's University, August 27, 2019

Interview with Ocel Dauphinais-Matheson, Visitor Experience Manager, Parks Canada, October 18, 2019.

Interview with Peter Mills, Director of Honours, Decorations, and Medals, Office of the Secretary to the Governor General, November 20, 2019.

Interview with Phil Craig and John Cannon, Liberation Tours, August 13, 2019.

Interview with Robert Holmes 'R.H.' Thomson, Artist, Creator, The World Remembers, September 16, 2019.

Interview with Robert Löken, National Manager for Honours, Awards, and Commemorations, Veterans Affairs Canada, November 20, 2019. 
Interview with Dr. Steve Harris, Director, Directorate of History and Heritage, August 1, 2019.

Interview with Dr. Tim Cook, Historian, Canadian War Museum, May 30, 2019.

\section{Primary Literature}

City of Ottawa. "City of Ottawa Municipal Commemoration Policy Development." March 23, 2018.

The World Remembers. “The World Remembers 1914-1918.” Look Book. March 2019.

\section{Secondary Literature}

Akyroyd, Peter, H. The Anniversary Compulsion: Canada's Centennial Celebrations, A Model Mega-Anniversary. Toronto: Dundurn Press, 1992.

Anderson, Benedict. Imagined Communities: Reflections on the Origin and Spread of Nationalism. London: Verso, 1991.

Beaton, Meaghan. The Centennial Cure: Commemoration, Identity, and Cultural Capital in Nova Scotia During Canada's 1967 Centennial Celebrations. Toronto: University of Toronto Press, 2017.

Bennett, Jane. Vibrant Matter: A Political Ecology of Things. Durham: Duke University Press, 2010.

Berton, Pierre. Vimy. Toronto: McClelland and Stewart, 1986.

Black, Iain S and Robert A. Butlin, eds. and Canadian National Identity," in Place, Culture and Identity: Essays in Historical Geography in Honour of Alan R. H. Baker. Quebec: Les Presses de 1’Universite Laval, 2001.

Bodnar, John. Remaking America: Public Memory, Commemoration, and Patriotism in the Twentieth Century. Princeton: Princeton University Press, 1992.

Boym, Svetlana. The Future of Nostalgia. New York: Basic Books, 2001.

Bradley, Ben. British Columbia by the Road: Car Culture and the Making of a Modern Landscape. Vancouver: University of British Columbia Press, 2017.

Budreau, Lisa M. Bodies of War: World War 1 and the Politics of Commemoration in America. New York: NYU Press, 2011. 
Butler, Shelley Ruth and Erica Lehrer. Curatorial Dreams: Critics Imagine Exhibitions. Kingston and Montreal: McGill-Queen's University Press, 2016.

Butz, David and Kathryn Besio. “Autoethnography.” Geography Compass 3, 5 (2009): 1660-1674.

Cadigan, Sean T. Death on Two Fronts: National Tragedies and the Fate of Democracy in Newfoundland, 1914-1934. Toronto: Penguin Group, 2013.

Clément, Dominique. "'Freedom' of Information in Canada: Implications for Historical Research.” Labour/Le Travail: 75 (2015): 101-131.

Cole, Tim. Selling the Holocaust: From Auschwitz to Schindler; How History is Bought, Packaged, and Sold. New York: Routledge, 1999.

Cook, Tim. At the Sharp End: Canadians Fighting the Great War. 1914-1916. Toronto: Viking Canada, 2007.

--. Shock Troops: Canadians Fighting the Great War1917-1918. Toronto: Viking Canada, 2009.

--. Vimy: The Battle and the Legend. Toronto: Penguin Random House, 2017.

DeLanda, Manuel. Assemblage Theory. Edinburgh: Edinburgh University Press, 2016.

Dyce, Matt. “"The Gateway to the Last Great West': Spatial Histories of the Athabasca Landing Trail.” Canadian Historical Review 94, 2 (2013): 177-206.

Dyer, Judy and Deborah Keller-Cohen. "The Discursive Construction of Professional Self Through Narratives of Personal Experience." Sage Journals 2, 3 (2000): 283-304.

Fairlie Wood, Herbert. Vimy! Toronto: Macmillan, 1967.

Goodspeed, D.J. The Road Past Vimy: The Canadian Corps 1914-1918. Toronto: MacMillan of Canada, 1969.

Gordon, Alan. Making Public Pasts: The Contested Terrain of Montreal's Public Memories, 1891-1930. Montreal and Kingston: McGill-Queen's University Press, 2001.

--. Time Travel: Tourism and the Rise of the Living History Museum in Mid-Twentieth Century Canada. Vancouver and Toronto: UBC Press, 2016. 
Gough, Paul. “'Contested memories: Contested site': Newfoundland and its unique heritage on the Western Front." The Round Table 96, 393 (2007): 693-705.

--. "Sites in the imagination: The Beaumont Hamel Newfoundland Memorial on the Somme." Cultural Geographies 11 (2004): 235-258.

Grandey, Alicia A. "Emotion Regulation in the Workplace: A New Way to Conceptualize Emotional Labour." Journal of Occupational Health Psychology 5, 1 (2000): 95-110.

Grandey, A.A., J.M. Diefendorff, and D.E. Rupp, eds. Emotional Labor in the 21st Century: Diverse Perspectives on Emotion Regulation at Work. New York: Routledge, 2013.

Greenhous, Brereton and Stephen Harris, Canada and the Battle of Vimy Ridge, 9-12 April 1917. Ottawa: Minister of Supply and Service, 1990.

Guattari, Félix and Gilles Deleuze. A Thousand Plateaus: Capitalism and Schizophrenia. Minneapolis: University of Minnesota Press, 1980.

Halbwachs, Maurice. On Collective Memory. Chicago: University of Chicago Press, 1992.

Hanley, Keith and John K. Walton. Constructing Cultural Tourism: John Ruskin and the Tourist Gaze. Bristol: Channel View Publications, 2011.

Hayday, Matthew. "Fireworks, Folk-dancing, and Fostering a National Identity: The Politics of Canada Day." Canadian Historical Review 91, 2 (2010): 287-314.

Hayday, Matthew and Raymond Blake. Celebrating Canada: Holidays, National Days, and the Crafting of Identities. Toronto: University of Toronto Press, 2016.

--. Celebrating Canada: Commemoration, Anniversaries, and National Symbols. Toronto: University of Toronto Press, 2018.

Hirsch, Marianne. The Generation of Postmemory: Writing and Visual Culture after the Holocaust. New York: Columbia University Press, 2012.

Hobsbawm, Eric and Terence Ranger. The Invention of Tradition. Cambridge: Cambridge University Press, 1983.

Hochschild, Arlie Russell. The Managed Heart: Commercialization of Human Feeling. Berkeley: University of California Press, 1983. 
Holt, Tonie and Valmai. Major \& Mrs. Holt's Battlefield Guide to Ypres Salient \& Passchendaele. Barnsley: Pen \& Sword Military, 2011.

Hucker, Jacqueline. "Battle and Burial: Recapturing the Cultural Meaning of Canada's National Memorial on Vimy Ridge.” The Public Historian 31, 1 (2009): 89-109.

Humphrey, Ronald H. and Blake E. Ashforth. "Emotional Labor in Service Roles: The Influence of Identity." Academy of Management Review 18 (1993): 18-115.

Humphrey, Ronald H., Blake E. Ashforth, and Diefendorff. "The Bright Side of Emotional Labor.” Journal of Organizational Behavior 36 (2015): 749-769.

Huyssen, Andreas. Present Pasts: Urban Palimpsests and the Politics of Memory. Stanford: Stanford University Press, 2003.

Ignatieff, Michael. Blood and Belonging: Journeys into the New Nationalism. New York: Farrar, Straus and Giroux, 1993.

Iles, Jennifer. "Recalling the Ghosts of War: Performing Tourism on the Battlefields of the Western Front." Text and Performance Quarterly 26, 2 (2006): 162-180.

Jiwani, Farzana Nanji and Tamara Krawchenko. "Public Policy, Access to Government, and Qualitative Research Practices: Conducting Research within a Culture of Information Control." Canadian Public History 40, 1 (2014): 57-66.

Kammen, Michael. Mystic Chords of Memory: The Transformation of Tradition in American Culture. New York: Vintage Books, 1993.

King, Alex. Memorials of the Great War in Britain: The Symbolism and Politics of Remembrance. London: Bloomsbury, 1998.

Kruml, Susan M. and Deanna Geddes. "Exploring the Dimensions of Emotional Labor: The Heart of Hochschild's Work." Management Communication Quarterly 41, 1 (2000): 8-49.

Landsberg, Alison. Prosthetic Memory: The Transformation of American Remembrance in the Age of Mass Culture. New York: Columbia University Press, 2004.

Latour, Bruno. "On Actor-Network Theory: A Few Clarifications plus More than a Few Complications.” Logos 27, 1 (1996): 173-197. 
--. Politics of Nature: How to Bring the Sciences into Democracy. Cambridge: Harvard University Press, 2004.

--. Reassembling the Social: An Introduction to Actor-Network Theory. Oxford: Oxford University Press, 2005.

Lennon, John J. and Malcom Foley. Dark Tourism: The Attraction of Death and Destruction. London: Thomson, 2006.

Lloyd, David W. Battlefield Tourism: Pilgrimage and Commemoration of the Great War in Britain, Australia, and Canada, 1919-1939. London: Bloomsbury, 1998.

Lowenthal, David. The Past is a Foreign Country. Cambridge: Cambridge University Press, 1985.

Macdonald, Sharon. Memorylands: Heritage and Identity in Europe Today. New York: Routledge, 2013.

Macintyre, D.E. Canada at Vimy. Toronto: P. Martin Associates, 1967.

Mackenzie, Susan Houge and John H. Kerr. "Stress and emotions at work: An adventure tourism guide's experience.” Tourism Management 36 (2013): 3-14.

Margry, Peter Jan, ed. Shrines and Pilgrimage in the Modern World: New Itineraries into the Sacred. Amsterdam: Amsterdam University Press, 2008.

McKay, Ian and Jamie Swift. The Vimy Trap, Or How We Learned to Stop Worrying and Love the Great War. Toronto: Between the Lines, 2016.

--. Warrior Nation: Rebranding Canada in an Age of Anxiety. Toronto: Between the Lines, 2012.

Miles, Stephen. "Remembrance trails of the Great War on the Western Front: routes of heritage and memory." Journal of Heritage Tourism 12, 5 (2016): 441-451.

Morgan, Cecilia. Commemorating Canada: History, Heritage, and Memory, 1850s1990s. Toronto: University of Toronto Press, 2016.

Müller, Martin. "Assemblages and Actor-networks: Rethinking Socio-material Power, Politics and Space." Geography Compass 9, 1 (2015): 27-41.

Murray, Martin J. Commemorating and Forgetting: Challenges for the New South Africa. Minneapolis: University of Minnesota Press, 2013. 
Mycock, Andrew. "The First World War Centenary in the UK: 'A Truly National Commemoration'?" The Commonwealth Journal of International Affairs 103, 2 (2014): 153-163.

Nelles, H.V. The Art of Nation-Building: Spectacle and Pageantry at Quebec's Tercentenary. Toronto: University of Toronto Press, 1999.

Nora, Pierre. Les Lieux de Mémoire (Realms of Memory): Rethinking the French Past: Volume 3 (Symbols). New York: Columbia University Press, 1998.

Osborne, Brian S. "Landscapes, Memory, Monuments, and Commemoration: Putting Identity in its Place." Canadian Ethnic Studies 33, 3 (2001): 39-77.

--. "Warscapes, Landscapes, Inscapes: France, War, and Canadian National Identity," in Place, Culture and Identity: Essays in Historical Geography in Honour of Alan R. H. Baker eds. Iain S. Black and Robin A. Butlin Les Presses de l'Universite Laval, 2001.

Peers, Laura. Playing Ourselves: Interpreting Native Histories at Historic Reconstructions. Langham: Rowman \& Littlefield Publishers, 2007.

Phillips, Mark Salber and Gordon Schochet, eds. Questions of Tradition. Toronto: University of Toronto Press, 2004.

Reed-Danahay, Deborah. Auto/ethnography: rewriting the self and the social. Oxford: Berg, 1997.

Roppola, Tiina, Jan Packer, David Uzzell, and Roy Ballantyne. "Nested assemblages: migrants, war heritage, informal learning and national identities." International Journal of Heritage Studies 25, 11 (2019): 1205-1223.

Rose, Julia. Interpreting Difficult History at Museums and Historic Sites. Langham: Rowman \& Littlefield Publishers, 2016.

Rothberg, Michael. Multidirectional Memory: Remembering the Holocaust in the Age of Decolonization. Stanford: Stanford University Press, 2009.

Rudin, Ronald. Remembering and Forgetting in Acadie: A Historian's Journey through Public Memory. Toronto: University of Toronto Press, 2009.

Samuel, Raphael. Theatres of Memory. Volume 1: Past and Present in Contemporary Culture. London: Verso, 1994. 
Savage, Kirk. "History, Memory, and Monuments: An Overview of the Scholarly Literature on Commemoration." University of Pittsburgh. Accessed January 10, 2021. https://www.nps.gov/parkhistory/resedu/savage.htm.

--. Monument Wars: Washington, D.C., the National Mall, and the Transformation of the Memorial Landscape. Berkeley: University of California Press, 2005.

Scates, Bruce. Return to Gallipoli: Walking the Battlefields of the Great War. Cambridge: Cambridge University Press, 2006.

Schama, Simon. Landscapes and Memory. Toronto: Vintage Canada, 1995.

Stone, Philip R., Rudi Hartmann, Tony Seaton, Richard Sharpley, and Leanne White, eds. The Palgrave Handbook of Dark Tourism. London: Palgrave Macmillan, 2018.

Sturken, Marita. Tourists of History: Memory, Kitsch, and Consumerism from Oklahoma City to Ground Zero. Durham: Duke University Press, 2007.

Timmers, M., Fischer, A. H., \& Manstead, A. S. R. “Gender motives for regulating emotions.” Personality and Social Psychology Bulletin 24,9 (1998): 974-985.

Tiro, Karim M. 'Now You See It, Now You Don't: The War of 1812 in Canada and the United States in 2012." The Public Historian 35, 1 (2013): 87-97.

Todman, Dan. The Great War: Myth and Memory. London: Bloomsbury, 2007.

Tyson, Amy. The Wages of History: Emotional Labor on Public History's Front Lines. Boston: University of Massachusetts Press, 2013.

Urry, John. The Tourist Gaze: Leisure and Travel in Contemporary Societies. London: Sage Publications, 1990.

--. The Tourist Gaze. London: Sage Publications, 2002.

Urry, John and Jonas Larsen. The Tourist Gaze 3.0. London: Sage Publications, 2011.

Walby, Kevin and Mike Larsen. "Access to Information and Freedom of Information Requests: Neglected Means of Data Production in the Social Sciences." Qualitative Inquiry 18, 1 (2011):

31-42.

Waterton, Emma and Jason Dittmer. "The Museum as Assemblage: bringing forth affect at the Australian War Memorial." Museum management and Curatorship 29, 2 (2014): 122-139. 
Watson, Janell. "Eco-sensibilities: An Interview with Jane Bennett." Minnesota Review 81 (2013): 147-158.

Wharton, A. S. and R.J. Erickson. "Managing emotions on the job and at home: Understanding the consequences of multiple emotional roles." Academy of Management Review 18, 3 (1993): 457-486.

Williams, Claire. "Sky Service: The Demands of Emotional Labour in the Airline Industry." Gender, Work, and Organization 10, 3 (2003): 513-550.

Winter, Jay. Remembering War: The Great War Between Memory and History in the Twentieth Century. New Haven: Yale University Press, 2006.

--. “The 'Memory Boom' in Contemporary Historical Studies.” Raritan 21, 1 (2001): 52.

Wong, Jehn-Yih and Chih-Hung Wang. "Emotional labor of the tour leaders: An exploratory study.” Tourism Management 30, 2 (2009): 249-259.

$\mathrm{Xu}$, Shi Tracy, Zheng Chris Cao, and Yuanyuan Huo. "Antecedents and outcomes of emotional labour in hospitality and tourism: A meta-analysis." Tourism Management 79 (2020): 104099.

Young, James E. The Texture of Memory: Holocaust Memorials and Meaning. New Haven: Yale University Press, 1993.

Yow, Valerie Raleigh. Recording Oral History: A Guide for the Humanities and Social Sciences. California: AltaMira Press, 2005.

\section{Online Articles / Websites}

“A New Plan for a Strong Middle Class." Liberal Party of Canada. October 2015. https://www.liberal.ca/wp-content/uploads/2015/10/New-plan-for-a-strong-middleclass.pdf.

"A window on Canada's First World War." Veterans Affairs Canada. Date Modified: January 21, 2020.

https://www.veterans.gc.ca/eng/remembrance/memorials/overseas/first-worldwar/france/vimy/education-centre/design-on-windows.

Akin, David. "Analysis: PM Trudeau is in France this Remembrance Day, just as he should be." Global New., November 10, 2018.

https://globalnews.ca/news/4650960/analysis-pm-trudeau-is-in-paris-this-remembranceday-just-as-he-should-be/. 
"Alex Decoteau Remembrance Run, Walk or Wheel." Veterans Affairs Canada. October 27, 2020. https://www.veterans.gc.ca/eng/remembrance/information-

for/educators/learning-modules/passchendaele/run-to-remember/alex-decoteau-run.

Alhadeef, Peter. "Canadian Prime Minister leads Centenary tribute on August $4^{\text {th }}, 2014$. ." Centenary News. https://centenarynews.com/article?id=2866.

Barry, Daniel. "Statue in honour of 'In Flanders Fields' poet to be erected in Ottawa to mark Centenary." Centenary News. January 31, 2014.

Bartlett, Geoff. "Prince Charles honours regiment at Beaumont-Hamel ceremony in France." CBC News. Posted: July 1, 2016.

https://www.cbc.ca/news/canada/newfoundland-labrador/beaumont-hamel-princecharles-1.3661410.

"Battles of the Ypres Salient." The Great War 1914-1918. 2009.

http://www.greatwar.co.uk/ypres-salient/battles-ypres-

salient.htm\#: :text=The $\% 20$ Allied $\% 20$ determination $\% 20$ to $\% 20$ protect,of $\% 20$ some $\% 202$ 4\%20square $\% 20 \mathrm{kilometres.}$

Beck, Julie. "The Concept Creep of 'Emotional Labor'," The Atlantic. November 26, 2018. https://www.theatlantic.com/family/archive/2018/11/arlie-hochschild-houseworkisnt-emotional-labor/576637/.

Berthiaume, Lee. "Historians unimpressed with Canada's First World War centenary commemorations." The Canadian Press. November 12, 2018. https://www.ctvnews.ca/politics/historians-unimpressed-with-canada-s-first-world-warcentenary-commemorations-1.4174008.

Bethune, Brian. "RH Thomson's The World Remembers commemorates sacrifice, one name at a time." Maclean's. November 7, 2018. https://www.macleans.ca/history/rhthomsons-the-world-remembers-mixes-art-with-remembrance/.

Bitonti, Daniel. "'In Flanders Fields' poet to be honoured with statues." CTV News. November 11, 2013. http://www.ctvnews.ca/canada/in-flanders-fields-poet-to-behonoured-with-statues-1.1538861.

“Books of Remembrance." Veterans Affairs Canada. Date Modified: May 24, 2019. https://www.veterans.gc.ca/eng/remembrance/memorials/books.

Campion-Smith, Bruce. "Books of names and a solemn ceremony honour Canada's war dead on Parliament Hill." The Star. December 17, 2018. https://www.thestar.com/news/canada/2018/12/17/books-of-names-and-a-solemnceremony-honour-canadas-war-dead-on-parliament-hill.html.

--. "War memorial changes stir controversy." The Star. November 11, 2014. https://www.thestar.com/news/canada/2014/11/11/war_memorial_changes_stir_controver sy.html. 
"Canadian Army well-represented at the $100^{\text {th }}$ anniversary of the Battle of Passchendaele." National Defence. November 9, 2017.

https://www.canada.ca/en/department-nationaldefence/news/2017/11/canadian_army_wellrepresentedatthe100thanniversaryofthebattleof.html

"Canadian National Vimy Memorial." Veterans Affairs Canada. Accessed January 10, 2021. https://www.veterans.gc.ca/pdf/memorials/vimy-self-guided-tour.pdf.

"Canada Outlines Great Wars Commemoration Plans at International Meeting in Paris." Veterans Affairs Canada. October 18, 2013.

https://www.canada.ca/en/news/archive/2013/10/canada-outlines-great-warscommemoration-plans-international-meeting-paris.html.

"Canadian produced sound and light show featured in Arras, France as part of Vimy 100 commemorative activities." Veterans Affairs Canada. March 14, 2017. https://www.newswire.ca/news-releases/canadian-produced-sound-and-light-showfeatured-in-arras-france-as-part-of-vimy-100-commemorative-activities-617034854.html.

"Canadian Route of Remembrance in Belgium 1915-1917: The Ypres Salient." Government of Canada. Date Modified: January 26, 2018. https://www.canadainternational.gc.ca/belgiumbelgique/bilateral_relations_bilaterales/route1915-17.aspx?lang=eng.

"Canadian veterans return to Juno Beach." Globe and Mail. June 6, 2014. https://www.theglobeandmail.com/news/national/canadian-veterans-return-to-junobeach/article24357684/.

"Canadian Virtual War Memorial: Private Francis Thomas Lind." Veterans Affairs Canada. Date Modified: February 26, 2020. https://www.veterans.gc.ca/eng/remembrance/memorials/canadian-virtual-warmemorial/detail/2742936.

Chan, Emily. "Canadians stop to remember $100^{\text {th }}$ anniversary of First World War." CTV News. August 4, 2014. https://www.ctvnews.ca/canada/canadians-stop-to-remember100th-anniversary-of-first-world-war-1.1945332.

"Commemorative ceremony and unveiling of the George Price Monument." Veterans Affairs Canada. Date Modified: February 12, 2019. https://www.veterans.gc.ca/eng/events/details/10275.

"Commemorative Partnership Program." Government of Canada. Date Modified: May 21, 2014. https://www.canada.ca/en/news/archive/2014/05/commemorative-partnershipprogram.html.

Daigle, Thomas. "The sights of Passchendaele, 100 years later." $C B C$ News. November 10, 2017. https://www.cbc.ca/news/canada/the-sights-of-passchendaele-100-years-later1.4396297. 
Doyle, Aileen. "Soil from Vimy arrives in Barrie for centennial celebration." CTV Barrie. June 3, 2016. https://barrie.ctvnews.ca/soil-from-vimy-arrives-in-barrie-for-centennialcelebration-1.2930656.

Gesner, Tara. "Vimy memorial restoration took years to complete." Carleton Place Almonte Canadian Gazette. April 7, 2017. https://www.insideottawavalley.com/newsstory/7231739-vimy-memorial-restoration-took-years-to-complete/.

"Government of Canada marks $100^{\text {th }}$ anniversary of the Battle of Beaumont-Hamel." Veterans Affairs Canada. July 1, 2016. https://www.newswire.ca/newsreleases/government-of-canada-marks-100th-anniversary-of-the-battle-of-beaumonthamel-585189171.html.

"Governor General to take part in the Aboriginal Spiritual Journey in France." Governor General of Canada. October 27, 2005. https://www.gg.ca/en/media/news/2005/governorgeneral-take-part-aboriginal-spiritual-journey-france.

Hartley, Gemma. "Women aren't nags - we're just fed up: Emotional labor is the unpaid job men still don't understand." Harper's Bazaar. September 27, 2017.

https://www.harpersbazaar.com/culture/features/a12063822/emotional-labor-genderequality/.

Higgins, Jenny. "Newfoundland and Labrador in the First World War: Beaumont Hamel: July 1, 1916." Newfoundland and Labrador Heritage. Revised: April 2015. https://www.heritage.nf.ca/first-world-war/articles/beaumont-hamel-en.php.

Hildebrand, Jim. "Loss is still felt after 100 years." The Pilot 57, 30 (July 20, 2016).

Hurley, Cory. "Inuit teen proud to participate in Beaumont Hamel ceremony." Saltwire Updated: September 30, 2017. https://www.saltwire.com/news/provincial/inuit-teenproud-to-participate-in-beaumont-hamel-ceremony-113665/.

"Inauguration of the 'Canadian road to Passchendaele' walk." The Great War in Flanders Fields. April 29, 2015. http://www.wo1.be/en/news/52146/inauguration-of-the-canadianroad-to-passchendale-walk.

"John McCrae statues to be unveiled a century after In Flanders Fields." The Canadian Press. Posted: April 19, 2015. https://www.cbc.ca/news/canada/john-mccrae-statues-tobe-unveiled-a-century-after-in-flanders-fields-1.3039564.

Laracy, Patrick. "Where once they stood." The Telegram 138, 84 (July 16, 2016).

Leicester, John, Raf Casert, and Lori Hinnant. "World leaders gather in Paris to mark end of First World War, to renew promise of peace." The Associated Press. Posted: November 11, 2018. https://globalnews.ca/news/4652566/world-leaders-paris-armisticepeace/.

MacIsaac, Chantelle. “An incredible experience.” The Gulf News (July 8, 2016). 
MacLennan, Robin. "CFB Borden making Canadian history with sacred soil collected at Vimy Ridge." BarrieToday. May 16, 2016. https://www.barrietoday.com/local-news/cfbborden-making-canadian-history-with-sacred-soil-collected-at-vimy-ridge-297023.

McKay, Millicent. "Devastation, distinction: Battle of Beaumont-Hamel is etched in Newfoundland's history." The Telegram. November 10, 2018.

https://www.thetelegram.com/in-depth/characters-of-strength/devastation-distinctionbattle-of-beaumont-hamel-is-etched-in-newfoundlands-history-258056/.

Memorial Museum Passchendaele 1917. "Australian Remembrance Trail.” Visit Flanders. December 2016.

https://www.visitflanders.com/en/binaries/Australian_Trail_Brochure_Passchendaele_tc m13-87756.pdf.

"National War Memorial." Veterans Affairs Canada. October 29, 2020. https://www.veterans.gc.ca/eng/remembrance/memorials/national-inventory-canadianmemorials/details/9429.

"One headstone at a time: behind a quest to document N.L. military gravesites." $C B C$ News. Posted: October 9, 2018. https://www.cbc.ca/news/canada/newfoundlandlabrador/trail-caribou-gravesites-1.4851676.

" $100^{\text {th }}$ Anniversary Battle of Passchendaele." The Governor General of Canada. November 3, 2017. https://www.gg.ca/en/media/news/2017/100th-anniversary-battlepasschendaele.

"Our Platform." Liberal Party of Canada. 2021. https://www2.liberal.ca/our-platform/.

"Our Signature Tour - Fall Edition." Liberation Tours. https://www.liberationtours.ca/nwe-f.html.

"Passchendaele Canadian Memorial." Veterans Affairs Canada. Date Modified: October 29, 2019. https://www.veterans.gc.ca/eng/remembrance/memorials/overseas/first-worldwar/belgium/Passchen.

"Passchendaele Memorial Park." VisitFlanders. Accessed January 10, 2021. https://www.visitflanders.com/en/things-to-do/attractions/top/passchendaele-memorialpark.jsp.

Power, William. "The second battle of Beaumont Hamel." The Telegram. September 13, 2016. https://www.thetelegram.com/opinion/local-perspectives/the-second-battle-ofbeaumont-hamel-136811/.

"Public Events for August 4, 2014." Government of Canada. August 3, 2014. https://www.canada.ca/en/news/archive/2014/08/public-events-august-4-2014.html.

Qualtrics $X M$ : https://www.qualtrics.com/. 
Robb, Peter. "Vimy's legend still looms large even after 100 years, historian Tim Cook says." Artsfile. March 27, 2017. https://www.artsfile.ca/vimys-legend-still-looms-largeeven-after-100-years-historian-tim-cook-says/.

"Statement by the Prime Minister of Canada on the $100^{\text {th }}$ anniversary of the start of the First World War." August 4, 2014.

https://www.canada.ca/en/news/archive/2014/08/statement-prime-minister-canada-100thanniversary-start-first-world-war.html.

Stone, Laura. "Canada's access-to-information system has worsened under Trudeau government: report." Globe and Mail. September 27, 2017.

https://www.theglobeandmail.com/news/politics/canadas-access-to-information-systemhas-worsened-under-trudeau-government-report/article36407309/.

"Student Guides in France." Veterans Affairs Canada. Date Modified: September 15, 2019. https://www.veterans.gc.ca/eng/remembrance/information-for/students/studentguide-program-in-france.

Sweet, Barbara. "Apology in Order." The Telegram. August 1, 2016. https://www.saltwire.com/news/provincial/apology-in-order-43794/.

--. "How Minister's speech got missed." The Telegram. September 2, 2016. https://www.thetelegram.com/news/local/how-ministers-speech-got-missed-127518/.

Taylor, Scott. "ON TARGET: Canada's defining moment came with a 'no' to Brits in 1922." The Chronicle Herald. November 18, 2018.

https://www.thechronicleherald.ca/opinion/on-target-canadas-defining-moment-camewith-a-no-to-brits-in-1922-260478/.

“The Trail of the Caribou Research Group.” Trail of the Caribou Research Group. 2018. https://trailofthecaribou.ca/.

"The Vimy Foundation Centennial Park." The Vimy Foundation. November 5, 2018. https://www.vimyfoundation.ca/the-vimy-foundation-centennial-park/.

“Timeline.” John McCrae Statue Project. Accessed January 10, 2021. https://www.lcolmccraestatue.ca/timeline.html.

"Trail of the Caribou." The Rooms. Accessed January 10, 2021. https://www.therooms.ca/thegreatwar/at-war/trail-of-the-caribou.

"Trail of the Caribou: Watch our full documentary online." CBC News. Posted: July 1, 2016. https://www.cbc.ca/news/canada/newfoundland-labrador/trail-of-the-caribou1.3661371.

Treble, Patricia. "Beaumont-Hamel is Newfoundland's raw wound." June 22, 2016. https://www.macleans.ca/society/why-beaumont-hamel-so-close-our-hearts/. 
“Trail of the Caribou." Veterans Affairs Canada. Date Modified: February 14, 2019. https://www.veterans.gc.ca/eng/remembrance/memorials/overseas/first-worldwar/france/beaumonthamel/caribou-trail.

“2017 Annual Report and Notice of 2018 Annual Meeting and Proxy Statement." TripAdvisor. Accessed January 10, 2021. https://ir.tripadvisor.com/static-files/840c6d1c9c17-46c9-b52f-3586ead2515f.

"Vimy Foundation Commends Federal Budget Announcement for New Education Centre." The Vimy Foundation. March 22, 2013. https://www.newswire.ca/newsreleases/vimy-foundation-commends-federal-budget-announcement-for-new-educationcentre-512119841.html.

"Visitor Experience (Vimy and Beaumont-Hamel)." Veterans Affairs Canada. Date Modified: February 14, 2019.

https://www.veterans.gc.ca/eng/remembrance/memorials/overseas/first-worldwar/france/BeaumontHamel/frequent-questions.

"Walks in and around Zonnebeke." The Great War in Westboek. Accessed January 10, 2021. https://www.flandersfields.be/en/do/walks-and-around-zonnebeke.

Wall, Lukas. "Beaumont-Hamel soil to be patriated during $100^{\text {th }}$ anniversary ceremonies.” CBC News. March 23, 2016.

https://www.cbc.ca/news/canada/newfoundland-labrador/french-soil-to-be-patriated$\underline{1.3503690 .}$.

Wilkinson, Sophie. "Why was everyone talking about emotional labour in 2017?" $B B C$. December 24, 2018. https://www.bbc.co.uk/bbcthree/article/5ea9f140-f722-4214-bb57$\underline{8 b 84 f 9418 \mathrm{a} 7 \mathrm{e}}$.

"World Wars Commemoration \#CanadaRemembers." Veterans Affairs Canada. Date Modified: April 16, 2019. https://www.veterans.gc.ca/eng/remembrance/world-warcommemorations.

Zilio, Michelle. "Queen salutes Canadian regiments in First World War commemoration." CTVNews.ca. April 19, 2015. https://www.ctvnews.ca/canada/queensalutes-canadian-regiments-in-first-world-war-commemoration-1.2334645.

\section{Pamphlets / Brochures}

Vanderbussche, Steven. Memorial Museum Passchendaele 1917: Experience. Reflect. Remember. Zonnebeke: MMP17. 2014.

\section{TripAdvisor Review Pages}

Beaumont-Hamel Newfoundland Memorial: https:/www.tripadvisor.ca/Attraction_Review-g2436295-d2428688-Reviews- 
Beaumont_Hamel_Newfoundland_Memorial-

Beaumont_Hamel_Somme_Hauts_de_France.html.

Canadian National Vimy Memorial: https://www.tripadvisor.ca/Attraction_Reviewg1472376-d547022-Reviews-Canadian_National_Vimy_MemorialGivenchy_en_Gohelle_Pas_de_Calais_Hauts_de_France.html.

Memorial Museum Passchendaele 1917: https://www.tripadvisor.ca/Attraction_Reviewg1235453-d2191951-Reviews-Memorial_Museum_Passchendaele_1917-

Zonnebeke_West_Flanders_Province.html.

Passchendaele Canadian Memorial: https://www.tripadvisor.ca/Attraction_Reviewg1235453-d8522194-Reviews-or5-The_Passchendaele_Canadian_MemorialZonnebeke_West_Flanders_Province.html\#REVIEWS.

Saint Julien Memorial: https://www.tripadvisor.ca/Attraction_Review-g188675d3211380-Reviews-Saint_Julien_Memorial-Ieper_Ypres_West_Flanders_Province.html. 